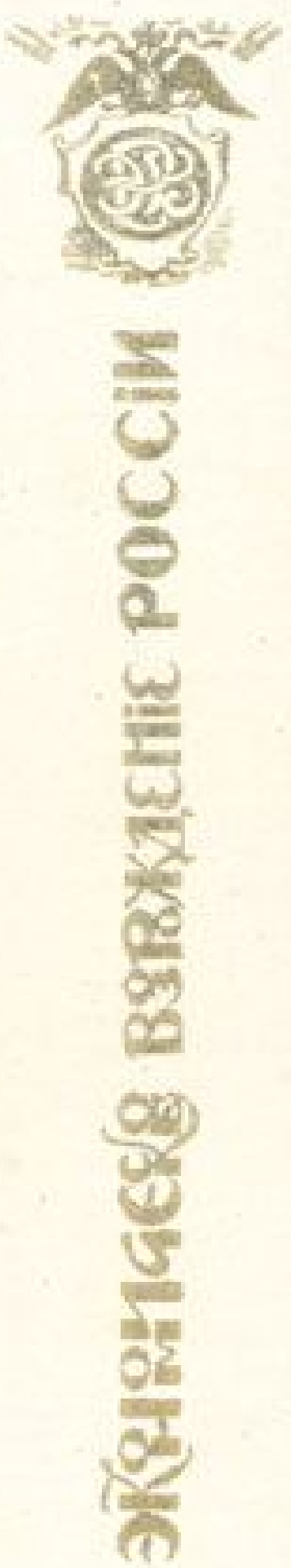

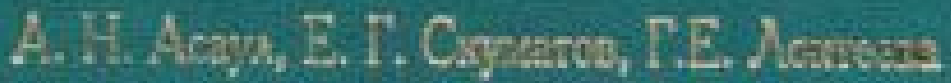

MATOROAOMULCTUE

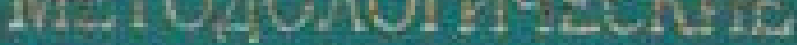

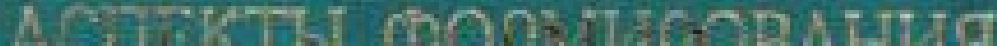

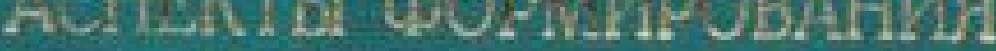

И PABВИTKЯ

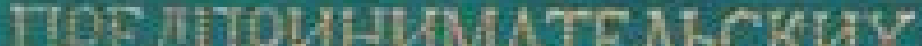

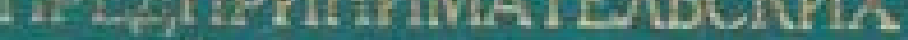

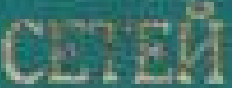

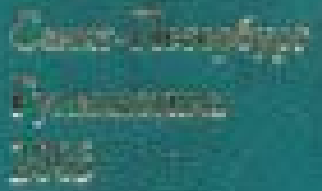



А. Н. АСАУЛ, Е. Г. СКУМАТОВ, Г. Е. ЛОКТЕЕВА

\section{МЕТОДОЛОГИЧЕСКИЕ АСПЕКТЫ ФОРМИРОВАНИЯ И РАЗВИТИЯ ПРЕДПРИНИМАТЕЛЬСКИХ СЕТЕЙ}

Под редакцией д. э. н., профессора А. Н. Асаула 
Асаул А. Н., Скуматов Е. Г., Локтеева Г. Е. Методологические аспекты формирования и развития предпринимательских сетей / Под ред. д. э. Н., проф. А. Н. Асаула. - СПб.: «Гуманистика», 2004. - 256 с.

\section{ISBN 5-86050-209-5}

В издании широко показано развитие отечественного предпринимательства. Особое место уделено теоретико-методологическим основам и сущности предпринимательства, целеполаганию, предпринимательской культуре и интрапренерству. Научным результатом книги является классификация предпринимательских сетей и системы их параметрического описания, а разработка принципов двухуровневого управления процессом создания и функционирования предпринимательских сетей, а также экономико-организационных механизмов их реализации на основе формирования локальных и комплексных бизнес-планов и целевых программ позволяет усовершенствовать систему управления строительством с учетом положений сетевого подхода к организации производственного цикла. В качестве практической части авторами предлагается обоснованный алгоритм разработки программы формирования предпринимательской сети и методические подходы к структурной оценке эффективности ее функционирования в инновационно-строительном комплексе.

Издание предназначено аспирантам, слушателям системы переподготовки и повышения квалификации специалистов, а также получения второго высшего образования, ученымэкономистам и руководителям высшего звена управления фирм.

\section{Для контактов с авторами: эл. почта asaul@yandex.ru}

\section{Рецензенты:}

М. П. Войнаренко, д-р эконом, наук, профессор, академик экономических наук Украины (Хмельницкий национальный университет)

M. М. Омаров, д-р эконом, наук, профессор (Новгородский государственный университет им. Яр. Мудрого)

E. В. Песоикая, д-р эконом, наук, профессор (Санкт-Петербургский государственный университет экономики и финансов)

(C) Асаул А. Н., Скуматов Е. Г., Локтеева Г. Е, 2004

(C) «Гуманистика», 2004 


\section{ВВЕДЕНИЕ}

Предпринимательство - это особый вид хозяйственной деятельности, которому присуще новаторство. Т. е. новаторство, приводящее к нарушению рыночного равновесия. А бизнес использует нарушения рыночного равновесия, вызванный предпринимательством. Когда есть разрыв между спросом и предложением, то бизнес, используя это, выпускает продукцию и получает дополнительный доход, как результат реализованной инициативы. С течением времени, когда все большее количество бизнесменов внедрит новейшие технологии, используя технологии предпринимателя, рынок выровняет условия для производства и обращения и в соответствии с законом полезности, дополнительный доход будет сокращаться. Снижение доходов заставляет бизнесменов проводить диверсификацию, способствуя восстановлению рыночного равновесия.

Логика рассуждения приводит к следующему выводу: предпринимательство отличается от бизнеса только одним существенным свойством - новаторством, приводящим к нарушению рыночного равновесия.

Предпринимательство в широком смысле, в отличии от бизнеса, встречается значительно реже, и как заметил Й. Шумпетер «предприниматель, остающийся таковым на протяжении десятилетий, встречается так же редко, как и коммерсант, который никогда в обычной жизни не бывал хотя бы немного предпринимателем» ${ }^{1}$ т. е. в повседневной жизни мы имеем дело с бизнесом. Бизнесмен может всю жизнь заниматься бизнесом и не быть предпринимателем, однако вся рыночная экономика без предпринимательства как социально-экономического феномена существовать не может.

В обиходе допускается равнозначность этих терминов, и это правильно, ибо узкий термин «предпринимательство» соответствует термину «бизнес» в широком смысле этого слова. В конкретном случае, когда речь идет о принципиальном различии между этими понятиями необходимо это уточнять.

Итак, - предпринимательство - это особый вид хозяйственной деятельности, суть которой заключается в стимулировании и удовлетворении спроса общества на конкретные потребности его членов, посредством рыночного обмена и направленной на завоевание конкурентных преимуществ через нарушение рыночного равновесия.

В современной экономической литературе в большинстве случаев сущность предпринимательства подменяется, целью предпринимательской деятельности. Так, например, в «Большом экономическом словаре» под общей редакцией А. Н. Азрилияна дается следующее определение: «Предпринимательство - инициативная самостоятельная деятельность граждан, направленная на получение прибыли и личного дохода, осуществляемая от своего имени, под свою имущественную ответственность или от имени и под юридическую ответственность юридического лица $)^{2}$. В учебниках предпринимательство определяется как непосредственная, самостоятельная, систематическая, на собственный риск деятельность по выполнению работ, оказанию услуг с целью получения прибыли, которая осуществляется физическими и юридическими лицами, зарегистрированными как субъекты предпринимательской деятельности в порядке, установленным законо-, дательством. Именно этот подход, в России закреплен законодательно ${ }^{3}$ Согласно современному российскому законо-

${ }^{1}$ Шумпетер Й. Теория экономического развития, М., 1982.С. 174.

${ }^{2}$ Большой экономический словарь. - М.: Институт экономики, 1994. - С. 313.

3 Закон РФ «О государственной поддержке малого предпринимательства в Российской Федерации» от 14 июля 1995 года № 88-ФЗ, ГКРФ и др 
дательству под предпринимательской деятельностью понимается «самостоятельная, осуществляемая на свой риск деятельность, направленная на систематическое получение прибыли от пользования имуществом - продажи товаров, выполнения работ или оказания услуг, лицами зарегистрированными в этом качестве в установленным законом порядке» ${ }^{* * * *}$.

А так ли это на самом деле? Прибыль - конечная цель предпринимательства? В принципе, прибыль является побудительным мотивом предпринимательской деятельности, а целью является создание продукта, т. е. удовлетворение спроса общества на конкретные потребности ее членов. Прибыль является мерилом успеха, только размером прибыли можно определить на сколько успешно сработал предприниматель и соответственно ее величина органически сопряжена с удовлетворением потребностей общества. Почти во всех учебниках говорится о том, что ключевым звеном предпринимательской деятельности является максимизация прибыли. Но в принципе, это не совсем так и в настоящей книге показано, что целевые устремления предпринимателя связаны с обеспечением долгосрочной устойчивости хозяйственной деятельности и с максимизацией его возможностей, возможностей предпринимателя удовлетворять комплекс его социально-экономических потребностей.

Теперь о сущности предпринимательства. Принято считать, что сущностью предпринимательства являются инициатива, риск, комбинация факторов производства и новаторство. Но это не сущностные характеристики предпринимательства - это лишь различные функциональные стороны предпринимательской деятельности которые должны рассматриваться лишь в качестве его признаков. Содержательный момент предпринимательства заключается как в завоевании преимуществ, так и в создании для себя лучших условий хозяйствования, что безусловно является главной специфической чертой предпринимательства как типа хозяйственного поведения. Результатом будет прибыль, как отражение реализованных конкурентных преимуществ.

Часто предпринимательская деятельность противопоставляется - хозяйственной. Авторы книги показывают, что это не совсем, так как совершенно ясно, что вся хозяйственная деятельность не может быть новаторством, а новаторство выступает формой проявления накопленных результатов в процессе хозяйственной деятельности, и только в последствии генерируется предпринимательская идея. Если отталкиваться от того, что предпринимательство это особый вид хозяйственной деятельности, одним из главных предметов которого является новаторство, то сразу напрашивается вопрос: а может ли быть малое предпринимательство? Малые предприятия - да, они указывают на размер коммерческой организации. А предпринимательство может ли быть малым? Может ли оно быть государственным? Насколько корректны такие термины. Напрашивается и такой вопрос: а предпринимательство коллективным может быть, или оно может быть только индивидуальным? Кто является носителем предпринимательства в новых экономических условиях Могут ли называться отечественные директора, руководители крупнейших акционерных обществ, предпринимателями, или они менеджеры? На этот и др. вопросы авторы пытаются найти ответ в настоящей книге.

За последнее десятилетие в поведении и сознании граждан государств СНГ произошли значительные изменения. Они вызваны, прежде всего, переходом к новой системе развития общества и активизацией предпринимательской деятельности. Объединение усилий предпринимателей, органов управления, субъектов инвестиционной и инновационной деятельности на определенной территории дает значительные преимущества в конкурентной борьбе, способствует рационализации производственно-рыночных процессов, перераспределению рисков и проведению гибкой политики, необходимой в условиях быстро меняющейся

${ }^{1}$ Гражданский кодекс РФ. Часть 1, Раздел 1, Подраздел 1., Гл. 1 ст. 2. 
конъюнктуры. Под воздействием гло-бализационных процессов в мировой экономике происходят изменения объекта хозяйственного управления. Так, в индустриальном обществе этим объектом управления выступали предприятия и фирмы, включающие несколько предприятий. В постиндустриальном, информационном - основным объектом хозяйственного управления становятся индустриальные, предпринимательские сети, представляющие планомерно организованную на основе долгосрочных контрактов сеть предприятий и организаций, участвующих в проектировании, производстве, реализации (а в жилищном строительстве и в сервисном обслуживании).

В объединениях традиционного типа (холдингах, концернах, трестах и т. д.) предприятия могут полностью или частично лишиться юридической, хозяйственной самостоятельности и т.д. Подобные объединения имеют, как правило, громоздкую управленческую структуру, что не позволяет им достаточно четко и своевременно реагировать на изменения внешней среды.

Кроме того, они имеют тенденцию к монополизации. Мировой и отечественный опыт показывают, что этих недостатков лишена сетевая форма организации научнопроизводственного цикла Такое объединение усилий в развитых странах оказалось достаточно эффективным. Поэтому предпринимательские сети (сетевые организации, индустриальные сети) привлекают гораздо больше прямых иностранных инвестиций, чем традиционные компании, сопоставимые по стоимости активов. В сетевых организациях между фирмами, принадлежащими разным собственникам, возникает родство при сохранении каждой из них своей автономности.

В экономике под сетью понимается способ регулирования взаимозависимости участников единого технологического процесса (отличающийся ' от координации их деятельности с помощью рыночных механизмов), основанный на кооперативной «игре», и особых отношениях.

Переход от чисто рыночных к сетевым отношениям кооперирующихся фирм в конце $\mathrm{XX}$ в. назван сетевой революцией. За последние годы по этой проблеме издано более 100 монографий (преимущественно в США, Великобритании, ФРГ). Эти работы посвящены анализу конкуренции в сетевых организациях, природе менеджмента снабженческих сетей и кооперативной стратегии в сетях, динамике межфирменного сотрудничества в сетевых альянсах.

Предпринимательская сеть является новой формой организации межфирменного взаимодействия, позволяющей быстро, инновационно адаптировать внутренние структуры и внешние взаимосвязи к быстро меняющейся неопределенности внешней среды. Сети позволяют оптимизировать межфирменные контакты, наладить эффективную кооперацию, согласовывать планы бизнес-субъектов — различных организаций участвующих в инвестиционно-строительной деятельности.

Экономические связи, лежащие в основе создания ПС, основаны на долгосрочных контрактах (в отличие от холдингов, базирующихся на имущественных интересах) и осуществляются на основе вертикальных и горизонтальных взаимодействий между различными бизнес-субъектами и их симбиозной взаимозависимости, определяемой принципом синергизма. Такие объединения позволяют малым организациям сочетать преимущества малых форм предпринимательства и крупных производств.

В сетевой организации сочетаются элементы рынка с иерархической координацией действий, но на первый план выходят кооперационные и информационные связи, а имущественные связи могут присутствовать в форме долевого участия.

Для достижения поставленных целей используются различные виды и методы кооперации. Формирование предпринимательской сети, в принципе, актуально для бизнесединиц любых отраслей и сфер деятельности. Однако отраслевая специализация определяет своеобразие потребностей и возможностей во взаимодействии соответствующих пред- 
приятий и организаций. 


\section{Глава I \\ ЭКОНОМИТЧЕСКИЕ ПРИНЦИПЫ И СОДЕРЖАНИЕ ПРЕДПРИНИМАТЕЛЬСТВА}

\section{1 Роль предпринимательства в российской экономике}

Древнерусское государство образовалось в 882 г., во многом благодаря зарождающемуся предпринимательскому духу восточных славян. Первое государство (Русь) объединило более 200 мелких славянских племен, а также некоторые финно-угорские и литовско-латышские племена.

Основными факторами возникновения древнерусского государства были военный и торговый. Славянское население, осваивая Среднерусскую равнину, селилось преимущественно по берегам рек, образовавших благоприятную систему коммуникаций. На севере это были Нева, Ладога, Волхов, Ильмень, Мета, Ловать и Шелонь; на западе - Западная Двина, и Неман; на юге - Днепр, Припять, Десна и Сож; на востоке - верховья Волги, Дон, Донец, Ворона, Волга-Каспий. Реки объединили славянские лесные и лесостепные земли и стали частью системы коммуникаций древнего цивилизованного мира. Греческие колонисты использовали Днепр как большую торговую дорогу («путь из варяг в греки»).

В этот период массовое размещение славян в этих местах приходится на VIIVIII вв. предпринимательская активность наших предков достигла высокого уровня, так как удалось не только освоить под хлебопашество лесные и лесостепные земли, но развить ремесла и выстроить крупные торговые города на всем протяжении торгового пути. Восточные славяне активно включились в международную торговлю, реализуя продукты собственных промыслов. Развитие торговли превратило разрозненные поселения в пункты обмена дарами леса и сельскохозяйственных продуктов.

По мере развития культурных потребностей, в результате совершенствования производительных сил, потребность в торговле усиливалась и соответственно развивалась потребность в предпринимательских качествах людей того времени. Наиболее постоянные и оживленные торговые связи наладились с Византией и черноморскими греческими колониями. Торговые договоры киевских князей с Византией заключались начиная с $\mathrm{X}$ в. и постоянно возобновлялись.

В X-XI в.в. активно развивалась внешняя торговля с восточными соседями, которые концентрировались вокруг Волги. Это были богатые торговые государства того времени: Хазарский каганат и Волжская Булгария. В Киеве в IX-X вв. имелся хазарский торговый двор - «урочище Козыря». В 1006 г. Владимир Святой заключил торговый договор с булгарами, разрешавший им беспошлинно торговать по всей территории Руси. Общение с волжскими народами позволило включиться в торговлю по Волжскому пути, являвшемуся ответвлением Великого 
шелкового пути ${ }^{1}$.

Оплотом развития предпринимательства становились города как ремесленноторговые центры. Скандинавские источники IX века именуют Русь «страной городов». При князе Владимире (конец IX в.) их было 25; в XI в. (период расцвета) более 89; перед нашествием Орды (начало XIII в.) - 2712.

Зачатками производственного предпринимательства можно считать мелкие кустарные производства. Первый русский писаный свод законов «Русская Правда», составленный при сыновьях Ярослава Мудрого в ХІ веке, свидетельствует о довольно высоком развитии денежного хозяйства, торговли, купеческого и ростовщического капитала. «Легко заметить ту общественную среду, которая выработала право, послужившее основанием Русской Правды», это был большой торговый город» ${ }^{3}$.

Таким образом, торговать и заниматься ремеслом было неотъемлемым правом каждого человека в России, не зависимо от его сословной принадлежности.

Один из древнейших русских актов, сохранившихся в подлиннике «Духовная Климента» (примерно 1270 г.) подтверждает широкое развитие товарно-денежных отношений. Новгородский купец Климент сочетал свою торговую деятельность с предоставлением кредитов ${ }^{4}$.

В известной новгородской былине о Садко, купец-предприниматель показан как герой-богатырь. При этом подвигом представлена его торговая деятельность.

Хорошо известен также тверской купец XV века Афанасий Никитин, автор «Хождения за три моря». Из этих записок следует, что русские купцы вели торговлю с разными странами не только ближними, но и дальними. Афанасий Никитин, как это явствует из текста, человек наблюдательный, общительный, смелый, предприимчивый. Последнее, впрочем, иногда ставится под сомнение, на том основании, что «предприимчивость» должна включать в себя не только смелость, «склонность к риску», но и «коммерческую ловкость, удачливость»5.

Историки свидетельствуют, что российским предпринимателям того периода были свойственны сочетание расчетливости и фантазии, напряженного труда и умения расслабиться, стремление быть собой, наличие глубокого и жесткого самоанализа.

Примером российского предпринимательства может быть и деловая жизнь монастырей. Монастырские колонии становились очагами хозяйственнопредпринимательской деятельности. Такие монастыри, как Кириллов-Белозерский, Троице-Сергиев, Соловецкий демонстрировали образцы формирования предпринимательских хозяйств. Немалый вклад в развитие предпринимательства

1 Никитина С.К. История российского предпринимательства.-М.: ЗАО «Издательство «Экономика», 2001.-303 с.

${ }^{2} 1000$ лет российского предпринимательства/Сост. О. Платонов.-М.: Современник, 1995.C. 3 .

${ }^{3}$ Ключевский В.О. Русская история. Полный курс лекций в трех книгах. Книга 1.-М., 1994.-С. 219.

${ }^{4}$ Духовна Климента//Памятники русского права.-М., 1953.

5 Лурье Я.С. Русский «чужеземец» в Индии XV века//Хождение за три моря Афанасия Никитина.-М., 1986.-С. 75. 
в России внесло казачество.

C XVI века в Московской Руси начинается расцвет торгово-промышленного предпринимательства, подкрепляемого столичным купечеством. Зарождаются целые поколения предпринимателей. Первым из них считают род Строгановых, ставших крупнейшими купцами и промышленниками в период с XVI по XX век.

Мощным импульсом развития предпринимательства в России стала эпоха Петра I. В частности число мануфактур при Петре увеличилось с 10 до 230. Одним из ярких примеров развития частной предпринимательской деятельности является рождение дома Демидовых. Сыновья и внуки основателя рода построили более 40 заводов, на которых производилось 40\% чугуна в России.

Сам Петр I по существу стал первым предпринимателем всей России, хотя бы уже потому, что ему в полной мере были присущи основные качества предпринимателя, а его деятельность впитала в себя предпринимательские начала. Частично перенимая предпринимательские подходы в Европе, Петр и порожденное им предпринимательское поколение создали основу российского торговопромышленного бизнеса [6].

При Екатерине Второй было разрешено всем сословиям создавать мануфактуры. Росла и развивалась мануфактура «капиталистых крестьян», прежде всего в легкой промышленности. Характерно возникновение Иваново-Вознесенского текстильного района. М.И. Туган-Барановский (1865-1919) в работе «Русская фабрика в прошлом и настоящем» (1898) пишет: «Село Иваново представляло собою в начале XIX века оригинальную картину. Самые богатые фабриканты, имевшие более тысячи человек рабочих, юридически были такими же бесправными людьми, как и последние голыши из их рабочих. Все они были крепостными Шереметьева». Организаторами крестьянской мануфактуры были инициативные, энергичные крепостные - Грачевы, Горелины, Бутримовы, Борисовы и другие ${ }^{1}$

Крупная промышленность, владельцами и организаторами которой были крепостные крестьяне, -один из парадоксов отечественной истории. «Капиталистический дух впервые проявился в России среди оброчных крестьян центральных губерний»,-подчеркивает Р. Пайпс². Крестьянин-предприниматель действовал в невообразимо тяжелых условиях, «лишь благодаря твердости своего характера и целеустремленности столь многим из них удалось преодолеть все препоны своего стесненного состояния» ${ }^{3}$.

Дальнейшее развитие предпринимательства в России также отличалось рядом особенностей, главная из которых сводится к следующему. Наша страна относится к группе стран (Германия, Италия, Япония), которые с определенным опозданием, во втором эшелоне, приступили к индустриализации своих экономик и как следствие вынуждены были часто опираться в своем утверждении не только на экономические, но и на административные методы. В экономике Российской империи государство играло особенно большую роль, так как основная ставка делалась не на свободу предпринимательства, как в Англии или США, а на государ-

${ }^{1}$ Юрьев В.М., Грошев И.В., Мамонтов В.Д., Смагина В.В. Предпринимательство России: очерки прошлого, настоящего, будущего.-Тамбов: Изд-во ТГУ им. Г.Р. Державина, 2002.-С. 27.

${ }^{2}$ Пайпс Р. Россия при старом режиме.-М., 1993.-С. 281.

${ }^{3}$ Там же. С. 282. 
ственное регулирование, что предопределило относительно жесткую подчиненность предпринимательской деятельности общегосударственным задачам и достаточно равнодушное отношение к низкой эффективности хозяйствования.

В дореформенный период (1861 г.) государство, оставаясь абсолютистским, продолжало опекать предпринимательскую деятельность путем административного надзора и всевозможной регламентации.

С началом реформ (1861 г.) в России начинается и второй этап развития предпринимательства. К этому времени в государстве насчитывалось 128 акционерных обществ с капиталом в 256 млн. руб., более двух сотен механических и литейных заводов с несколькими десятками тысяч рабочих. Реформа (19.02.1861 г.) дала импульс широкому и интенсивному развитию частного предпринимательства. В этом году в Петербурге появился первый в России частный коммерческий акционерный банк. В 1866 году была выдана первая концессия на постройку железной дороги Козлов - Воронеж. Прошли первые форумы отечественных предпринимателей - первый купеческий съезд (1865 г.) и первый Всероссийский съезд фабрикантов и заводчиков (1870 г.). Получила бурное развитие ведущая в современном рыночном хозяйстве форма предпринимательства: акционерно-паевая.

Отдельно следует заметить, что в рамках крестьянского хозяйства, реформа 1861 г. закончилась запретительными мерами - продажа и залог земли, выход из общины, а также ущемлялась личная свобода крестьянства. Однако процесс обнищания и разорения крестьянства как раз и вел к развитию предпринимательства в рамках капиталистических отношений. Отсталость крестьянского хозяйства, его низкий технический уровень, господство средневековых форм общинного землевладения при острой нехватке денежных средств вели к расширению отсталых, нерациональных форм хозяйствования.

В период с конца 50-х гг. ХІХ в. до Первой мировой войны (1914) мощный государственный сектор охватывал, кроме таких традиционно казенных отраслей, как связь, транспорт, оборонная промышленность, также и металлургию, горное производство, нефтедобычу, сельскохозяйственное производство, что вызывало недовольство предпринимателей. В главной отрасли российской экономики сельском хозяйстве - казенными были в среднем 40\% земельных угодий, а по отдельным губерниям, в частности в Волгодонской и Архангельской - до 85-99\%.

Российская промышленность развивалась в данный период главным образом по линии вытеснения вотчинно-дворянской фабрики частнопредпринимательской промышленно - купеческой фабрикой, а затем за счет кустарных и мануфактурных предприятий. Российское законодательство в те годы выделяло такие организационные структуры предпринимательства, как единоличные организации, торговые дома и акционерно-паевые общества.

Торговые дома были двух видов: полные товарищества и товарищества на веpe. В товариществе на вере, помимо несших полную ответственность «товарищей», участниками торгового дома были еще и лица отвечающие в пределах своего вклада. Лицам, отдавшим предпочтение такой организационной форме предпринимательства, как торговый дом, было достаточно всего лишь простого засвидетельствования в купеческих или городских управах, и дело считалось открытым Учреждение же организаций акционерно-паевого типа, а также изменение каких- 
либо существенных условий их деятельности осуществлялось с разрешения правительства на основе законодательных актов.

К концу XIX - началу XX в. ведущую роль в промышленности Российской империи стали играть акционерные и паевые предпринимательские структуры. Цепь акционерных обществ - мобилизация широкого круга лиц. В паевых предпринимательских структурах, где капитал уже имелся, пайщики руководствовались мотивами расширения и развития дела, стремясь к ограничению круга пайщиков в целях сохранения решающей роли за прежними владельцами организации.

К рубежу двух веков акционерно-паевые предпринимательские структуры (около 1300 ед.) доминировали в отраслях, давших вместе 2/3 всей промышленной продукции. В отраслях, выпускавших оставшуюся 1/3 промышленной продукции господствовало, за небольшими исключениями, единоличное предпринимательство. Они играли ведущую роль, например, в мукомольном производстве, в лесоперерабатывающей промышленности, в винокурении и шерстяной промышленности. Крупные же единоличные организации конкурировали на равных с акционерными и паевыми организациями практически во всех отраслях российской промышленности.

Удельный вес акционерных обществ в валовом производстве был наиболее высоким в резиновой промышленности (89.7\%) и цементном производстве (42.4\%), льняной промышленности (48.5\%) и бумажной - (35.3\%).

К началу века наметились тенденции монополистического объединения российских предпринимателей. Несмотря на то, что интенсивные процессы монополизации экономики дооктябрьской России развернулись на 10 лет позднее (начало 80-х годов XIX в,), нежели чем в Западной Европе, к началу XX в. в стране насчитывалось уже около 140 различных монополистических объединений в 45 отраслях промышленности. Процессы монополизации охватили ведущие отрасли промышленности. В остальных отраслях они развивались чаще всего в каком-либо отдельном производстве: в промышленности стройматериалов, к примеру, было монополизировано цементное производство, а в пищевкусовой - сахарорафинадHoе.

На рубеже XX века произошло вытеснение с лидирующих позиций мелкого и среднего предпринимательства крупными организациями. Если в 1890 г. крупные организации с годовым производством 100 тыс. рублей и более преобладали в 8 отраслях, то всего лишь через 10 лет, в 1900 г., крупное предпринимательство преобладало уже в 21-й отрасли (83.1\% валового промышленного производства). Процессы монополизации и оттеснения мелкого и среднего предпринимательства сопровождались резким сокращением общего количества предпринимательских единиц: с 31799 в 1890 г. до 24572 в 1908 г. ${ }^{1}$

Хотя отечественные предприниматели прибегали практически ко всем формам монополистических соглашений, включая тресты и концерны, в преобладающем числе случаев они объединялись в синдикаты. Первый в Российской империи синдикат (гвоздильных и проволочных заводов) возник в 1886 году, в следующем

\footnotetext{
${ }^{1}$ Раку Ю.И. Из истории предпринимательства// Предприниматель, № 1-2, 1992.
} 
году синдикат образовали сахарозаводчики. В 1895 году они добились введения государственной сахарной нормировки, предусматривавшей ограничение производства сахара и его поставок на внутренний рынок в целях поддержания на нем высоких цен. Однако наиболее активно образование синдикатов в российской промышленности происходила в 1902 - 1904 гг. В этот период начали функционировать объединения синдикатского типа "Трубопродажа", "Продвагон”, "Продуголь", "Продамет”, который объединил 30 металлургических заводов, монополизировав таким образом 4/5 всей дооктябрьской металлургической продукции. Тем не менее, в рассматриваемый период в нашей стране монополия одной организации была исключением.

Типичной же была иная ситуация - олигополия нескольких крупных организаций. В резиновой промышленности, например, конкурировали “Треугольник” и “Проводник”, в нефтяной промышленности - “Товарищество Нобель”, “ Англоголландский трест" и "Русское генеральное нефтяное общество".

В сельском хозяйстве, в начале века, наметился переход от мелкотоварного производства, основанного на личном труде, к крупному товарному производству.

По указу от 9 ноября 1906 г. признавались следующие виды собственности на землю: общинная; надельная (семейная); личная.

Предпочтение, при этом, отдавалось личной собственности. Считалось, что общинное землевладение препятствует развитию крупного товарного производства. В этот период уже появились зачатки предпринимательского риска, так как вышеназванный указ не гарантировал частного собственника от возможной утраты собственности, а, следовательно, средств производства.

Развивалась крестьянская кооперация, производственные и торговые товарищества. После 1917 г., кооперация в короткий срок превратилась в мощную централизованную систему, способную выполнить общегосударственные задачи. Всеми видами кооперативов было охвачено почти 7 млн. крестьянских хозяйств или около 26 млн. человек.

Жизненность принципов кооперирования подтверждались развитием не только простейших, но и высших форм кооперирования - колхозов. Особенно с переходом к НЭПу деятельность колхозов была поставлена на более прочную организационную и хозяйственную основу. В этот период складываются различные организационные формы колхозов: коммуны, артели, товарищества по совместной обработке земли. Нужно заметить, что к концу 1925 г. артели составляли две трети всей численности колхозов. НЭП обеспечивал материальную заинтересованность крестьянства в развитии своего хозяйства, в максимальном увеличении его продукции.

Зарубежная деятельность российского предпринимательства чаще всего сводилась к экспорту товаров, который резко преобладал над вывозом капитала. С 1900 по 1913 г. оборот внешней торговли Российской империи вырос в два с лишним раза, в основном за счет хлеба. Его экспорт в предвоенные пять лет в среднем составлял 727 млн. пудов. Россия занимала, как известно, первое место по вывозу хлеба (1/3 мирового экспорта хлеба), оставляя позади Аргентину и США. 
В Западную Европу российские предприниматели вывозили преимущественно сырьевые товары, а также продовольствие: лес, лен, кожу, яйца, хлеб. В восточные страны - промышленные товары, главным образом хлопчатобумажная ткань, шерсть, нефтепродукты, марганцевая руда, стекло, металлические изделия.

Экспорт же капитала не практиковался отечественными предпринимателями в сколько-нибудь широких масштабах. Они вывозили свой капитал в основном в страны Востока. Особенно значительные капиталовложения были помещены в Китае и Манчжурии - 750 млн. рублей. Напротив, иностранные предприниматели активно инвестировали свой капитал в нашу экономику, что играло существенную роль в развитии российской экономики. На начало 90-х годов приходится период особо интенсивного прилива иностранного капитала. Эти капиталовложения составляли более трети всех капвложений в российские ценные бумаги. Доля участия иностранных предпринимателей в российских акционерных обществах также росла довольно высокими темпами: в 1893 году она составила 23\% , в $1900-$ $35 \%$, в $1908-40 \%$. Иностранные предприниматели вкладывали свой капитал преимущественно (3/5 от общей суммы) в три отрасли российской промышленности - горную, металлургическую и металлообрабатывающую. В горной промышленности, к слову, удельный вес зарубежного капитала уже в 1890 году превышал вклады отечественных предпринимателей, а к концу XX века составлял вообще $70 \%$.

Первое место по числу и по сумме акционерного капитала в начале XX века занимали бельгийские общества, функционировавшие главным образом в каменноугольной, металлургической промышленности, металлообработке, производстве стройматериалов, а также в сфере городского транспорта Российской империи. На втором месте закрепились французские предприниматели, а третье место занимали германские общества, вкладывавшие свой капитал в основном в химию, электропромышленность и банковское дело'.

В целом предпринимательство во второй половине XIX в. - начале XX в. получило наибольшие в России возможности развития. Однако противоречия общественной и экономической системы не могли оказать влияния на развитие предпринимательства. Попытки более энергично идти по пути реформ, предпринятые Витте, Столыпиным, до такой степени изменили жизнь людей, что сообщество всей силой своих традиций и энергии «под корень уничтожило недостаточно прочные основания частного интереса и социальной независимости». Тем более, что предпринимательская деятельность и ее носители давали много поводов для недовольства, даже ненависти, со стороны других групп населения. Но можно утверждать, что не сама предпринимательская деятельность, а условия, в которые она была поставлена в России, заставляли ее носителей обманывать, приспосабливаться, обходить закон, который все запрещает, - и все это в гораздо больших объемах, чем при нормальных экономических отношениях. Если бы капитализм развивался естественно и постепенно, он бы проникал в жизнь людей определенными привычками, этическими и профессиональными нормами, которые бы передавались из поколения в поколение. Такой постепенности не было отпущено

\footnotetext{
${ }^{1}$ Раку Ю.И. Из истории предпринимательства.// Предприниматель, № 1-2, 1992.
} 
России даже в самый благоприятный период в истории отечественного предпринимательства - 1861-1917гг.

Период с октября 1917 года до начала 20-х годов можно условно назвать третьим этапом развития отечественного предпринимательства. Его особенностью было широкое вытеснение предпринимательства из экономической жизни. Такая политика вытекала из марксистских представлений о коммунистическом обществе. Рассматривая предпринимательскую деятельность, классики марксизма связывали ее, прежде всего, с частной собственностью и эксплуатацией, хотя и признавали созидательные и организаторские функции предпринимателя.

Во-первых, производительный труд сводился марксистами к преобразованию предметов труда и управлению этим процессом; предпринимательский же доход рассматривался как часть прибавочной стоимости, а деятельность, направленная на получение предпринимательского дохода - как форма эксплуатации рабочего класса. Во-вторых, обобществление производства трактовалось, в основном, как его огосударствление, национализация частного имущества, превращение народного хозяйства в единую фабрику, сверхсиндикат. В - третьих, планомерность понималась как централизованное установление заданий по производству, поставкам и ценам на продукцию всех участков этого синдиката, а распределение по труду — как оплата по количеству и сложности труда, затраченного на выполнение плановых заданий, практически без учета соотношения затрат и результатов ${ }^{1}$.

Эти выводы верны не для любой экономики, а лишь для той, которая действует при административно-командной системе, где народное хозяйство рассматривается как одна фабрика, а партийно-государственный центр - как единственный собственник и предприниматель. Поэтому во всех сферах общественной жизни установилась государственная монополия. Была осуществлена национализация крупных промышленных предприятий, а через некоторое время и мелких частных предприятий. В сельском хозяйстве упор делался на уравнительный передел земли с последующим развитием крупных коллективных хозяйств. Введение хлебной монополии государства подрывало конкуренцию между производителями сельхозпродукции. Монопольное положение государства, централизация, лишение самостоятельности производителей, устранение конкуренции между ними - все это тормозило развитие предпринимательства. Однако, говорить, что предпринимательские отношения в те годы не существовали будет неправильно. Предпринимательской деятельностью продолжало заниматься немалое количество мелких и средних самостоятельных (частных) хозяев. Одни из них относились к “бывшим”, другие в условиях мелкотоварного сектора экономики только нарождались. Тем не менее, сфера предпринимательской деятельности постоянно сужалась. Государство проводило свою политику последовательно и бескомпромиссно.

Период НЭПа знаменовал собой новый (четвертый) этап. Началом НЭПа можно считать утверждение Советом Труда и Обороны (СТО) «Основных положений к восстановлению крупной промышленности, поднятию и развитию производства» от 12.08.1926 г., где провозглашался перевод промышленных трестов на

\footnotetext{
${ }^{1}$ Бляхман Л. Предпринимательство в России. Экономика и организация. - СПб, СПб ГУ, 1995.
} 
хозяйственный и коммерческий расчет. Далее было принятие ЦИК и СНК СССР 29.06.1927 г. «Положения о государственных трестах», юридически оформившего произошедшую на практике трансформацию коммерческого хозрасчета в хозрасчет административный. В концепции новой экономической политики возрождение предпринимательской деятельности рассматривалось как вынужденная необходимость, отступление перед капитализмом. В период НЭПа интересы государства, как никогда ранее, были четко сформулированы: держать предпринимателей для своих целей, «... лишь в меру допустить развитие этих отношений, которые полезны и необходимы в остановке мелкого производства, и чтобы контролиро-

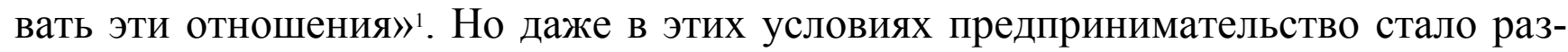
виваться на всех уровнях.

Предпринимательскими функциями, по своей сути, прежде всего, стало заниматься государство, что, в частности, проявилось в концессиях. Концессия представляла собой договор между Советским государством и иностранным капиталистом, в соответствии с которым, капиталисту передавались для эксплуатации определенные объекты или участки земли. Расчет с государством производился как в натуре - произведенной продукцией, так и в денежной форме. От использования объекта концессионер получал прибыль. По видам собственности концессии делились на смешанные (государственный и частный капитал вносились на паях) и частные (весь капитал принадлежал иностранцу).

Первые договора о концессиях были заключены уже в 1921 г. В их числе можно назвать концессию между правительством РСФСР и Большим Северным телеграфным обществом на эксплуатацию подводных телеграфных линий между Россией, Данией, Японией, Китаем, Швецией и Финляндией; русско-германское общество воздушных сообщений “Дерулюфт” и другие.

Особой сферой экономической деятельности государства в эти годы являлось содействие и прямое участие в акционерных обществах. Акционерная форма широко использовалась государством как организационная форма государственных предприятий. Так появились государственные и смешанные акционерные общества. Наибольшего расцвета акционерное предпринимательство достигло к середине 20-х годов.

Многоукладный характер экономики, возрастание роли экономических факторов развития создавали благоприятные предпосылки для развития предпринимательства и на более низких уровнях. Отражением этого процесса явился переход к многообразию форм хозяйствования: аренде, кооперации, акционированию, коммандитным товариществам и т.д. В литературе тех лет такие объединения напрямую назывались капиталистическими.

Годы НЭПа создали благоприятные предпосылки для активизации частного предпринимательства. Так как этому способствовали два обстоятельства: денационализация мелких предприятий и законодательное разрешение учредительской деятельности. Без предварительного уведомления местных органов власти частные лица могли, например, открыть промышленное предприятие с числом наемных рабочих от 10 до 20 человек. С момента официального признания частных

\footnotetext{
1 Ленин В.И. Полн. собр. соч. Т. 43, стр. 222.
} 
предпринимателей они весьма успешно стали конкурировать с государственными предприятиями. Небольшие производства позволяли гибко реагировать на изменения конъюнктуры рынка, ибо мелкий бизнес незамедлительно пользовался ошибками и трудностями госпредприятий. Конечно, нельзя преувеличивать успехи частных предпринимателей, так как в их деятельности было немало и негативных черт (беспощадная эксплуатация наемных рабочих, нездоровая криминогенная обстановка и т.д.).

Оценивая в целом годы НЭПа, следует отметить, что оживление деловой активности ускорило процесс экономической реконструкции. К середине 20 -х годов были почти полностью восстановлены тяжелая промышленность и транспорт, превысило довоенный уровень сельскохозяйственное производство, впечатляющих результатов добилась торговля. Изменения в экономике способствовали повышению уровня жизни людей. Однако в этот период предпринимательство рассматривалось как чуждое социализму явление, и поэтому экономические условия развития предпринимательской деятельности в тот период слабо укреплялись.

Пятый этап в истории отечественного предпринимательства был самый драматичный. Он охватил период, длившийся около 60 лет - с конца 20-х годов до второй половины 80-х годов. Это был период безраздельного господства административно - командной системы. Из легального сектора экономики предпринимательство практически было изгнано (если не считать остатков индивидуальноремесленнической деятельности) и перешло на нелегальное положение, переместившись в теневую экономику. Став одной из составных частей этого сектора экономики, предпринимательская деятельность в меньших масштабах и с большей для себя опасностью все же продолжала свое существование.

Уйдя “в тень”, предприниматели пытались реализовать свой коммерческий опыт через спекуляцию под вывеской колхозной или комиссионной торговли. Предприимчивые рабочие организовывали частное производство предметов хозяйственного обихода, запасных частей и изделий. На протяжении десятилетий “теневики” весьма успешно конкурировали с государственным сектором. Например, государство производило новую технику, но не обеспечивало ей соответствующую инфраструктуру. На этой основе развивался частный автосервис, другие виды услуг. Конкурентоспособности “теневого" бизнеса способствовала его ориентация на спрос, гибкость производства, высокий оборот капитала.

Трудности государственной экономики невольно способствовали активизации теневиков. Не случайно последние десятилетия были годами резкого увеличения масштабов теневой экономики. Если в начале 60-х годов ее годовой объем в стране исчислялся в размере 5 млрд. рублей, то к концу 80-х годов эта цифра составляла уже 90 млрд. рублей.

В 80-е годы, когда стали наблюдаться некоторые новые явления, направленные на повышение трудовой активности, В частности, была поставлена задача о коренной перестройке самой системы хозяйствования. Административнокомандная система стала разрушаться, формировались условия для перехода к рыночной модели общества. Был поставлен вопрос о формировании нового экономического мышления, составной частью которого называлась социалистическая предприимчивость. Это потребовало принципиальным образом изменить от- 
ношение к таким явлениям, как частная собственность, конкуренция, предпринимательство.

Во второй половине 80-х годов при возрождении некогда забытых форм хозяйствования - подряд, аренда, кооперация - начался шестой этап развития предпринимательства.

На начало 1988 г. 90 \% всех кооперативных предприятий и более 90 \% реализованной ими продукции приходилось на производство товаров народного потребления, бытового обслуживания, заготовки и переработки вторичного сырья. Кооперативы объединяли различные виды деятельности. К 1991 г. они охватывали более 20 видов производств и услуг, в том числе строительные работы, работы по производству стройматериалов и продукции производственнотехнического назначения, сельскохозяйственные, научно-технические, по оказанию медицинских услуг, художественно-оформительские, работы по организации досуга, транспортные услуги и т. п. Их насчитывалось 134,6 тыс.

Особенность кооперативного сектора заключалась в том, что он существенным образом зависел от государственного и развивался на его основе, так как более $80 \%$ кооперативов было создано при госпредприятиях, у которых они арендовали 58 \% основных фондов. Только 36 \% основных фондов принадлежали кооперативам. Часть кооперативов, по существу, превратились в частнопредпринимательские предприятия. Кооперативам, организованным при предприятиях или в их составе присущи проблемы. Во-первых, такие кооперативы, как правило, не выходили напрямую на потребительский рынок и работали, прежде всего, на внутрипроизводственные нужды. А ведь именно с развитием кооперации связывались надежды на пополнение рынка потребительских товаров и услуг. Вовторых, они были каналом перевода безналичных финансовых ресурсов в наличные.

Именно в это время происходит наиболее быстрый рост малых предприятий в различных организационно-правовых формах. В 1990 г. в стране насчитывалось уже 200 тыс. малых предприятий, на которых было занято почти 5 млн. человек, объем производимой ими продукции оценивался в 40 млрд руб.

Этому способствовало принятие новых законов о собственности, о предприятиях и предпринимательской деятельности и ряда других. Так, в частности, в Законе РСФСР “О предприятиях и предпринимательской деятельности” предпринимательство понимается как инициативная самостоятельная деятельность граждан и их объединений, направленная на получение прибыли. «Предпринимательская деятельность осуществляется гражданами под свой риск и под имущественную ответственность в пределах, определяемых организационно-правовой формой предприятия, в условиях развития самостоятельности, инициативы, ответственности, риска, активного поиска, динамичности, мобильности» ${ }^{1}$. Таким образом, под развитие предпринимательской деятельности в 1990 г. подведена юридическая основа.

1992 г. характеризовался самыми высокими с середины 80-х годов темпами

${ }^{1} \mathrm{O}$ предприятиях и предпринимательской деятельности. Закон Российской Федеративной Социалистической республики № 445-1 от 25.12.1990 г.// Экономика и жизнь, № 4, 1991. 
роста числа малых предприятий (в 2,1 раза) и численности занятых в них (7,7 \% от общего числа занятых). В это время наблюдается становление рыночной инфраструктуры (коммерческие банки, биржи, оптовые и посреднические организации и т. п.), коммерческой торговли, укрепление финансовых институтов.

С началом широкомасштабной приватизации развитие предпринимательства получает мощный импульс. В это время (1993-1994 гг.) появилось множество собственников и интенсивное участие малого предпринимательства в сфере услуг, торговли, общественного питания, легкой промышленности, производящей товары массового потребления и длительного пользования. Были заложены основы рыночных отношений. Сформировавшиеся капиталы давали основание предполагать об их способности к инвестиционной деятельности, к развитию предпринимательства. В результате разгосударствления и приватизации предприятий развивается свободная конкуренция, как необходимый атрибут рыночных отношений.

Развитие малого предпринимательства происходит по следующим основным направлениям:

создание общественных организаций и фондов поддержки, что позволяет не только не угаснуть малому предпринимательству, но и сохранить свои активные позиции в региональной экономике;

развитие базовых элементов системы информационного обеспечения малого предпринимательства на региональном уровне, включая необходимые технические и программные средства, организационные решения, базы данных;

совершенствование законодательной и нормативной базы в области государственной поддержки малого предпринимательства;

реализация инновационных процессов в малом предпринимательстве;

осуществление мероприятий по кредитованию малого предпринимательства.

Статистические данные свидетельствуют, что в 2002 г. работало более 875 тыс. малых предприятий с общей занятостью свыше 7,5 млн. человек. Доля в производстве ВВП при таких показателях составляет более 10 \%.

Для рыночной экономики важна не только рыночная конкуренция, но и другая характеристика, именуемая «концентрация капитала». Именно поэтому при достижении определенных экономических результатов, объективно необходимым стало создание крупных организаций корпоративного типа. По отношению к ним малое предпринимательство выступает как источник факторов производства, как рынок сбыта готовой продукции и источник личной предпринимательской инициативы ${ }^{1}$. Основной и главной особенностью развития предпринимательства современной России является соответствие таким условиям деятельности, когда малое предпринимательство и корпоративный сектор предполагают параллельность действия и взаимовлияние.

Как показывает не только зарубежная, но и отечественная практика появление корпоративных структур вытекает из логики развития предпринимательства, когда накопленные ресурсы полностью (или почти полностью) вкладываются в развитие собственно предпринимательства.

${ }^{1}$ Макинтайр Р. Малые предприятия в экономике переходного периода: анализ проблем и экономическая политика//Экономическая наука современной России, 2002..-№ 1.-С. 125. 
Особенность предпринимательства в рамках корпоративной структуры заключается в том, что, несмотря на хозяйственную независимость объединенных организаций, существуют сильные взаимные этические, организационные, финансовые, деловые и иные связи, делающие корпоративные структуры устойчивыми и надежными партнерами в предпринимательской деятельности.

Способы организации, формы и методы функционирования ФПГ обеспечивают эффективность их деятельности и способствуют консолидации промышленного и финансового капитала. Региональные ФПГ развиваются в регионах с диверсифицированной экономической структурой. Деятельность ФПГ технологического направления получили развитие в нефтегазодобыче и нефтепереработке, в металлургии и производстве композитных материалов, машиностроении, деревообработке, производстве материалов для жилищного строительства в инвестиционно-строительном комплексе.

С целью расширения возможностей предпринимательства в области строительно-монтажных работ, промышленности, научной и проектной деятельности на добровольной основе создаются ассоциации, создаваемые по отраслевому, межотраслевому и территориальному признаку.

Таким образом, на современном этапе развития предпринимательства быстро складывается самоорганизующийся корпоративный сектор экономики, субъектами которого являются такие формы объединений как ФПГ, ассоциации и др. Этот факт свидетельствует о новом повороте и переходе на иные социальноэкономические и политические отношения в начале 21 века'.

Правовой фундамент предпринимательства в России в настоящее время составляют:

1. Конституция РФ от 12.12.1993 г., которая гарантирует единство экономического пространства, свободное перемещение товаров, услуг и финансовых средств, поддержку конкуренции, свободу экономической деятельности, признание и защиту равным образом частной, государственной, муниципальной и иных форм собственности.

2. Гражданский кодекс РФ (ч. I принята 21.10.94, ч. II - 26.01.1996) - это своего рода «конституция» предпринимательства, так как в нем унифицировано правовое регулирование рыночных отношений, закреплены основные принципы гражданско-правового регулирования, обеспечены неприкосновенность и равенство защиты всех форм собственности, гарантировано развитие не противоречащих закону видов предпринимательской деятельности.

3. Федеральные законы Российской Федерации специального назначения: «Об акционерных обществах» от 26.12.1995г. №202-Ф3; «О некоммерческих организациях» от 12.01.1996 г. №7-Ф3; «О производственных кооперативах» от 8.05.1996 г. № 41-Ф3; «Об обществах с ограниченной ответственностью» от 8.02.1998 г. № 14-Ф3.

4. Федеральные законы Российской Федерации общего назначения: «О государственной поддержке малого предпринимательства в РФ» от 12.05.1995 г.; «О

${ }^{1}$ Подробнее см.: Асаул А.Н., Батрак А.В. Корпоративные структуры в региональном инвестиционно-строительном комплексе.-М.: Изд-во АСВ; СПб.: СПбГАСУ, 2001-168 с. 
конкуренции и ограничении монополистической деятельности на товарных рынках» от 22.03.1991 г.; «Об инвестиционной деятельности» от 26.06.1991 г.; «Об иностранных инвестициях» от 04.07.1991 г.; другие федеральные законы, указы Президента, постановления Правительства, нормативные акты федеральных и местных органов власти.

Не рассматривая критически сущность этих документов, отметим, что к настоящему времени в России создана современная, достаточная и полная нормативноправовая база для предпринимательской деятельности. 


\section{2. Генезис теорико-методологических основ в предпринимательстве}

В римском праве «предпринимательство» рассматривалось как занятие, дело, деятельность, особенно коммерческая.

Эволюция терминологической, содержательной сущности предпринимателя и предпринимательской деятельности связана с историей становления обмена, производства и распределения товаров и услуг, с уровнем развития научнотехнического прогресса (прил. 1).

Достаточно простое и весьма емкое определение предпринимательства дает В.И. Даль. В частности, он пишет, что «предпринимать» означает «затевать, решаться исполнить какое-либо новое дело, приступать к совершению чего-либо значительного»: отсюда «предприниматель» - «предпринявший» что-либо.

В современной экономической литературе в большинстве случаев сущность этого явления подменяется целью предпринимательской деятельности. Так, например, в «Большом экономическом словаре» под общей редакцией А. Н. Азрилияна дается следующее определение: «Предпринимательство - инициативная самостоятельная деятельность граждан, направленная на получение прибыли или личного дохода, осуществляемая от своего имени, под свою имущественную ответственность или от имени и под юридическую ответственность юридического лица» ${ }^{1}$ В учебниках предпринимательство определяется как непосредственная, самостоятельная, систематическая, на собственный риск деятельность по выполнению работ, оказанию услуг с целью получения прибыли, которая осуществляется физическими и юридическими лицами, зарегистрированными, как субъекты предпринимательской деятельности в порядке, установленном законодательством. Именно этот подход, в России закреплен законодательно ${ }^{2}$ Согласно современному российскому законодательству под предпринимательской деятельностью понимается «самостоятельная, осуществляемая на свой риск деятельность, направленная на систематическое получение прибыли от пользования имуществом - продажи товаров, выполнения работ или оказания услуг, лицами, зарегистрированными в этом качестве в установленном законом порядке»³ (рис. 1.1).

${ }^{1}$ Большой экономический словарь.- М.: Институт экономики, 1994.- С. 313.

2 Закон РФ "О государственной поддержке малого предпринимательства в Российской Федерации" от 14 июля 1995 года № 88-Ф3, ГКРФ и др.

${ }^{3}$ Гражданский кодекс РФ. Часть 1, Раздел 1, Подраздел 1., Гл.1 ст.2. 


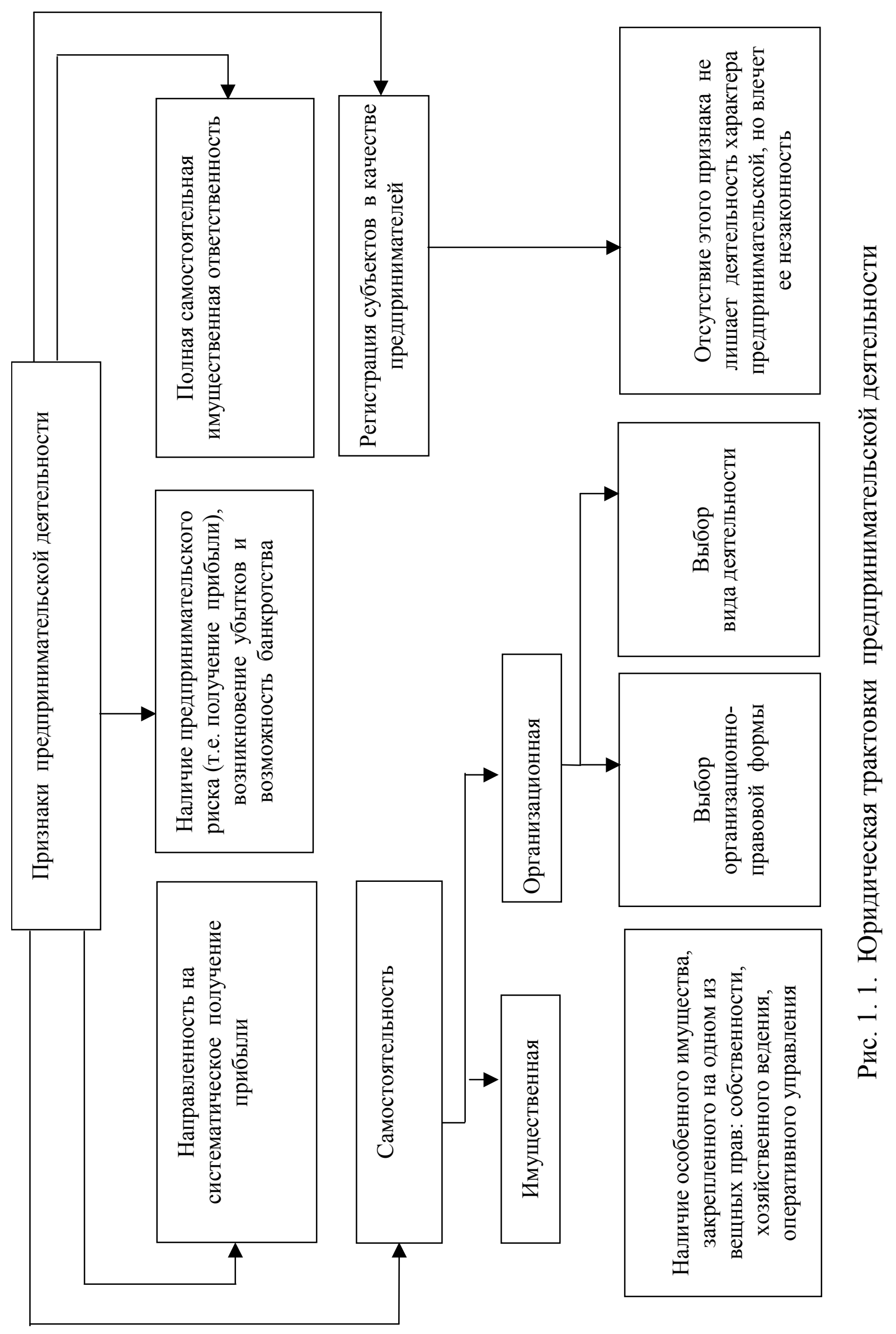


Предпринимательство принято определять как:

деятельность, направленную на максимизацию прибыли;

инициативную предпринимателей, заключающуюся в производстве товаров и оказании услуг, результатом которой является прибыль;

процесс организационной новации;

прямую функцию реализации собственности;

действия, направленные на возрастание капитала, и развитие производства;

специфический вид деятельности, направленный на неустанный поиск изменений в существующих формах жизни предприятий и общества, постоянная реализация этих изменений;

как стиль хозяйствования;

как процесс организации и осуществления деятельности в условиях рынка;

как взаимодействие субъектов рынка и т.д.

Рассматривая предпринимательство как продукт рыночного хозяйства, в историческом аспекте, мы видим, что развитие рыночного хозяйства является катализатором изменений в предпринимательстве, а именно: организационных форм, предпринимательских функций, масштабов и сфер применения.

Соответственно и терминологическая сущность и содержание, вкладываемые в понятие «предпринимательство», менялись и упорядочивались в процессе развития экономической теории.

Принято считать, что одним из первых, кто серьезно заинтересовался предпринимательством, был А. Смит. Однако лет за десять до него этими проблемами очень интенсивно занимался Р. Кантильон.

Именно он сформулировал тезис, согласно которому расхождения между спросом и предложением на рынке дают возможность отдельным субъектам рыночных отношений покупать товары дешевле и продавать их дороже. Именно он назвал этих субъектов рынка предпринимателями («предприниматель» - в переводе с французского «посредник»), а новые явления хозяйственной деятельности - предпринимательством.

Процесс развития теории предпринимательства проходил на основе осмысления практики предпринимательства в четыре этапа: на первом этапе внимание концентрировалось на риске предпринимателя. Р. Кантильон в XVIII веке впервые выдвинул положение о риске в качестве основной функциональной характеристики предпринимательства.

Утверждалось, что предприниматель - это любой индивид, обладающий предвидением и желающий принять на себя риск, устремленный в будущее, чьи действия характеризуются не только надеждой получить доход, но и готовностью к потерям. Последователями этой теории были представители немецкой классической школы XIX века И. Тюнен и Г. Мангольдт, а также американский экономист Ф. Найт.

В исторической ретроспективе исходным пунктом приложения предпринимательской инициативы была торговая деятельность, которая была связана с перемещением товаров с рынка на рынок, а источником дохода служила разница в 
ценах. В этот период предпринимательство играло подчиненную, вспомогательную роль, а его функциональное содержание ограничивалось поиском сфер прибыльного приложения капитала, притом в условиях практически полного отсутствия институциональной организации рыночного хозяйства. $B$ этих условиях доминирующими признаками предпринимательства были высокая степень риска и, соответственно, стремление $к$ максимизачии прибыли, а предпринимательская функция являлась монополией собственника, единоначально определяющего все сторонь своей деятельности и возлагающего на себя полную ответственность за ее результатьл. Не случайно именно эти признаки и были зафиксированы экономистами XVIII века как определяющие сущность предпринимательства.

По мере усложнения предпринимательской деятельности и обособлений функций, собственности и управления содержательный момент предпринимательства переносится в сферу организации и управления им¹.

Развитие этих представлений неоклассической теории привело к интерпретации предпринимателя как менеджера, комбинирующего факторами производства, а предпринимательство - как управленческой функции ${ }^{2}$, которая как утверждает Д.Б. Кларк - не связана ни с трудом, ни с собственностью на капитал; она состоит целиком в установлении и поддержании эффективных взаимодействий между факторами производства.

Bmорой эman научного осмысления предпринимательства концентрирует внимание на личности предпринимателя. В. Зомбарт и Ж. Пилевский рассматривали предпринимателя и предпринимательство в исторической перспективе, акцентируя внимание на преимуществах обществ где действуют люди с предпринимательскими способностями. Однако в, целом, эту волну связывают с именем Й. Шумпетера, полагавшего, что в основе экономического развития положена специфическая функция предпринимателя, которая проявляется всякий раз в стремлении использовать «новую комбинацию» факторов производства, следствием чего является нововведение, инновация. Если вместо количества факторов мы меняем саму форму функции, то получаем нововведение». Трактовка предпринимательства как новаторства, а предпринимателя как лица являющегося движущей силой прогрессивных изменений в экономике соответствовала этапу развертыввания НТР.

Многофункциональная модель предпринимательства возникла на третьем эmane со второй половины $\mathrm{XX}$ в. в результате теоретических исследований Й. Шумпетера, а также представлений новоавстрийской школы Л. Мизеса и Ф. Хайека. В них впервые предпринимательство было рассмотрено как процесс развития идеи, а их последователь И. Кирцнер построил теорию предпринимательства как процесс перехода от одного равновесного состояния «арбитражных» сделок к другому.

С точки зрения Й. Шумпетера, специфическая роль предпринимателей состоит в преодолении инерционности экономической системы и стремления хозяй-

${ }^{1}$ Ж.Б. Сэй, Дж.С.Милль

${ }^{2}$ А. Маршалл, К Меигер, Л. Вальрас, Ф Визу, Д.Б. Кларк, Дж.Р.Хикс. 
ственных субъектов действовать согласно установившимся практикам ${ }^{1}$. Сама по себе экономическая система обладает, по Шумпетеру, колоссальным инерционным потенциалом. Любая инновация в хозяйственной сфере сопряжена с определенным риском, которого большинство экономических субъектов стремятся избежать. В результате они чаще склонны действовать традиционно, а не новаторски, даже в ущерб собственной выгоде: бизнесмены не спешат вкладывать капитал в новые предприятия (даже если их рентабельность не вызывает сомнений), управляющие предпочитают сохранять профиль корпоративной деятельности (даже если другие отрасли представляют возможности для роста), работники не любят менять место работы (даже если им предлагают более выгодные условия).

Поскольку такая инерционность является свойством социальноэкономической среды, субъекты хозяйствования часто не склонны к инновациям не в силу собственной неадекватности, а как раз наоборот - по причине рациональной природы их действий. Стремление адаптироваться к устойчиво функционирующей среде заставляет отказываться от выгодных капиталовложений, внедрения новых технологий, кадровых комбинаций и т. п. «Наилучшие с экономической точки зрения и технически наиболее совершенные комбинации [производительных сил], - пишет Й. Шумпетер, - хотя и с неизбежностью, но все же очень часто не совпадают, причем вследствие приспособления экономики к правильно распознанным условиям, а не просто в силу отсутствия знаний или инертности» $^{2}$.

При этом Й. Шумпетер указывает, что наибольшие прибыли и убытки получаются в результате стихийных, заранее непрогнозируемых изменений внешней среды. В результате именно таких изменений возникают новые ситуации, приспособление к которым требует некоторого времени. «И до того, как это произошло, в народном хозяйстве можно наблюдать значительное число случаев положительной или отрицательной разницы между издержками и доходами» ${ }^{3}$ Речь идет о возможности получения определенным предприятием конкурентного преимущества в условиях неожиданного изменения внешней среды. Логика Й. Шумпетера заключается в том, что предпринимательство представляет собой, деятельность по сознательному внесению возмущений в хозяйственную среду в расчете на получение конкурентного преимущуества и, как следствие, высокого дохода.

$\mathrm{C}$ переходом к индустриальной стадии производства, приоритетной сферой приложения предпринимательства становятся отрасли материального производства. Теперь уже не игра на разнице рыночных цен, а поиск наиболее рациональной комбинации применяемых факторов, то есть эффективного способа производства, становится условием предпринимательского успеха. Усложнение деятельности повлекло за собой усложнение и предпринимательской функции, обусловившее ее рассредоточение в соответствии с управленческой структурой хозяйственной организации. Предпринимательская функция перестает быть монополией собственника, а содержательная сторона предпринимательства усматривается в комбинировании факторами производства с целью их наиболее эффективного использования.Производить, в концепции И.

\footnotetext{
${ }^{1}$ Шумпетер И. Теория экономического развития. М., 1982. С.63-64.

${ }^{2}$ Там же. С. 73.

${ }^{3}$ Там же. С. 98.
} 
Шумпетера, означает «комбинировать имеющиеся в нашей сфере вещи и силы» ${ }^{1}$. Производственная инновация - это создание новой комбинации такого рода. Рыночная конкуренция представляет собой не что иное, как конкуренцию таких комбинаций ${ }^{2}$, одни из которых оказываются сильнее и приносят их авторам (или хозяевам) доходы и почести, другие - не оправдывают возлагавшихся на них надежд, их инициаторы не получают вознаграждения, а часто и компенсации за вложенные силы и средства,

Вклад этого ученого в развитие теоретической базы исследования феномена предпринимательства определяется двумя факторами:

Й. Шумпетер первым: 1) представил развернутую концептуальную схему анализа предпринимательства как самостоятельного феномена, не сводимого напрямую к феномену капиталистического производства, 2) дал развернутое обоснование позитивной роли предпринимателей в экономической системе, положив тем самым начало развитию конструктивных теорий предпринимательства.

Современный этап развития теории предпринимательства можно отнести к четвертому этапу. Постиндустриальная стадия развития общества с характерными для нее ростом роли новаторства и социализации производства, установила иные приоритеты хозяйствования. Не рационализация использования ресурсов, $a$ рационализация самой формы и способа хозяйствования становится ключевым звеном предпринимательской деятельности. Целевые устремления связаны, $c$ обеспечением долгосрочной устойчивости хозяйственной организации, а не с максимизацией частного результата. Ключевую роль играет не приспособление к меняюшимся условиям, а способность преобразовывать сами условия хозяйствования в соответствии с тенденцииями развития общественных потребностей $и$ производства. Поэтому в постиндустриальной экономике инновационная деятельность становится определяющим признаком предпринимательства, а само оно начинает играть главенствующую роль в общественном производстве. В трудах П. Друкера ${ }^{3}$ рассматривается не только сущностные, но и управленческие аспекты предпринимательской деятельности, переходя на междисциплинарный уровень анализа. Работы Г. Пиншота положили начало формированию современных концепций внутрифирменного предпринимательства, укрепили понимания предпринимательства как глобального процессного явления, не обязательно ассоциируемого с понятием собственности.

На научное осмысление предпринимательства оказали влияние и достижения институциональной теории, рассматривающей организации (в том числе и предпринимательские) как открытые системы. Создание синергетической экономической теории, описывающих неравновесное динамично эволюционирующее сообщество разнообразных открытых экономических систем, повлияло на понимание самого понятия «предпринимательство».

Синергетический подход, исходящий из открытости системы акцентирует взаимосвязь предпринимателя и среды его деятельности - определяет предпринимательство как процесс самообновления и самоорганизации индивидуумов $u$ предприятий, осущеествляемый во взаимодействии с внешней и внутренней сре-

${ }^{1}$ Шумпетер И. Указ. соч. С. 158

${ }^{2}$ Там же. С. 160

${ }^{3}$ Друкер П. Эффективное управление. Экономические задачи и оптимальное решение. М.:Фаир-пресс. 
дой. Этот процесс преследует цель максимизации возможностей предпринимателя удовлетворять комплекс его соииально-экономических потребностей (а не максимизация прибыли) в рамках неравновесного динамического баланса противоречивых социально-экономических интересов участников этого процесса - индивидуумов, организаций и общества в целом. Принципиальная особенность синергетического подхода к теории предпринимательства содержится в учете единства предметно - материального и идеально-творческого начал в предпринимательской деятельности ${ }^{2}$ (рис. 1.2).

\footnotetext{
${ }^{1}$ Колесникова Л. Предпринимательство: от «максимизации прибыли» к синергии социально-экономических систем//Вопросы экономики.-2001.-№ 10.

${ }^{2}$ Необходимо отметить, что старообрядческий тип хозяйствования, сыгравший ключевую роль в развитии русского предпринимательства, предполагает неразрывную связь материальной жизни с высокой религиозной духовностью, связь действий в природном мире с миром божественным, ибо не существует «чистого» духа, без материи. Значит, и спастись можно, преобразуя не только свою душу, мир мыслей и чувств, но и свое тело и окружающий мир, в котором оно живет и действует.
} 


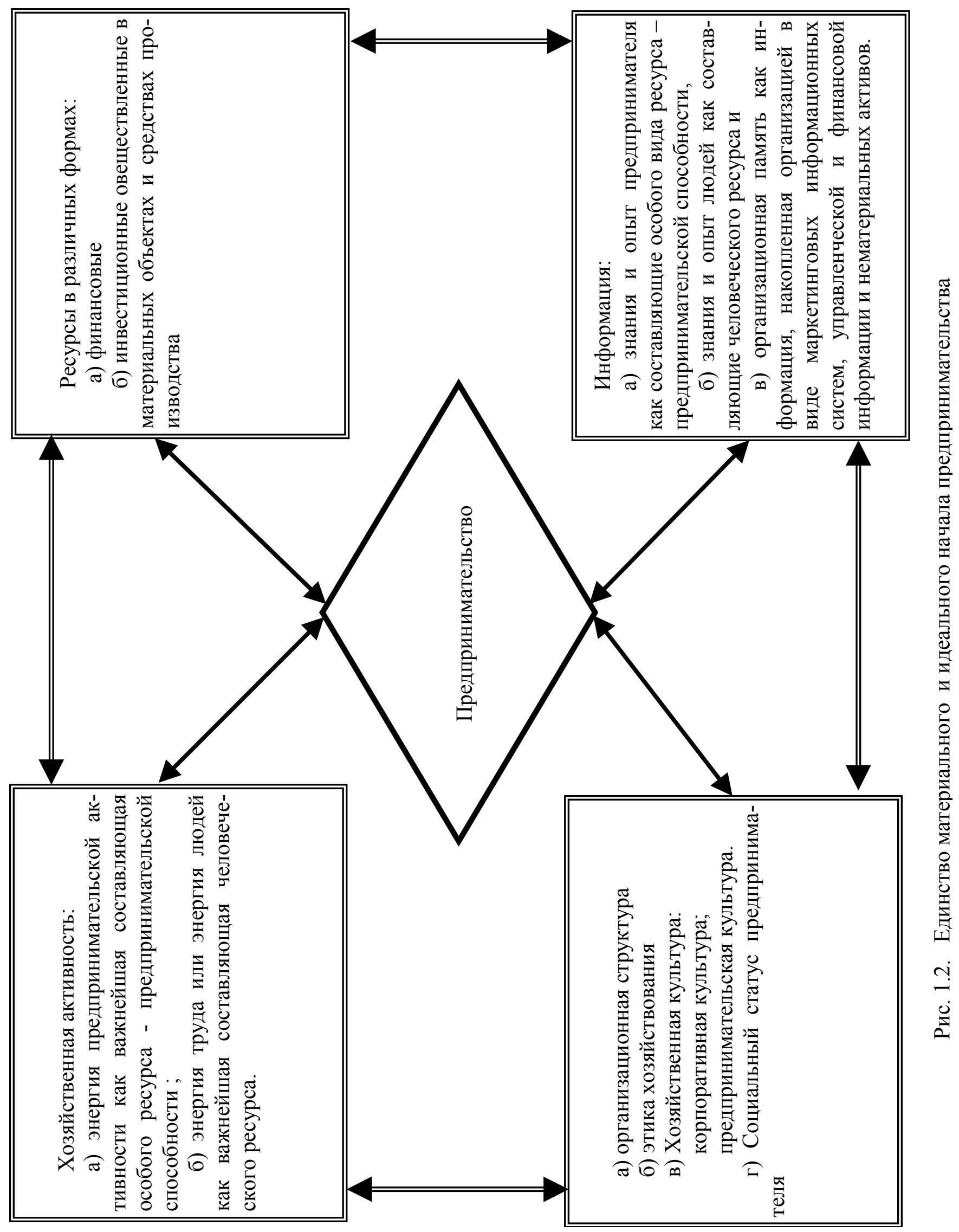

В сущности, специфика предпринимательства как особого типа хозяйственного поведения выражается в непрерывно осуществляемой цепи обменных опера- 
ций. Между тем, сам по себе обмен становится источником предпринимательства только тогда, когда превращается в составное звено единого хозяйственного оборота, а производство для обмена становится определяющей функцией хозяйствующих субъектов. Роль обмена в генезисе предпринимательства трудно переоценить.

Во-первых, обмен выступает исходным и конечным пунктами предпринимательства. Во-вторых, именно в процессе обмена предприниматель усматривает источник возможной выгоды, являющейся одновременно и мотивом, и оценкой успеха предпринятой им инициативы. В-третьих, сталкиваясь в процессе обмена с подобными себе лицами, предприниматель воспринимает свою деятельность как состязательную.

Наконец, изменение условий обмена выступает определяющим фактором развития предпринимательства. Все это свидетельствует о том, что именно в обмене предпринимательство идентифицирует себя, как особый тип хозяйственного поведения, а стадия обмена является определяющей его природу. Анализируя экономическую природу предпринимательства с этих позиций, мы видим, что принимаемые внешние его проявления в качестве сущностных черт- инициатива, риск, комбинирование факторами производства и новаторство - на самом деле отражают лишь различные функииональные стороны деятельности по осуществлению предпринимательства и могут рассматриваться лишь в качестве его признаков ${ }^{1}$.

Предпринимательская инищиатива имеет экономическую природу и связана $c$ наличием рыночной неопределенности и экономической свободы. В этом смысле она не должна рассматриваться как свойство человеческой натуры, а как стремление к реализации предоставляемых самим процессом рыночного обмена возможностей извлечения выгодbl. Поскольку такой обмен осуществляется к взаимной выгоде участников этого процесса, то предпринимательскую инициативу следует ассочиировать, с извлечением выгоды посредством удовлетворения общественных потребностей. Поэтому содержательным моментом предпринимательства является не механическое перераспределение в свою пользу существующих благ, а созидание дополнительных. Благодаря предпринимательской инициативе происходит нарушение рыночного ровновесия как в сфере обращения, так и в сфере производства.

Другой признак предпринимательства - коммерческий риск отличающийся от простого риска тем, что принятие его связано с нацеленностью на обращение рыночной нестабильности и неопределенности возникающих не только в силу изменчивости рыночных условий (изменения конъюнктуры, цен, предложений), но и как реакция на инициативы предпринимателей) в свою пользу, в форме определенного вознаграждения, а не со склонностью предпринимателей к риску.

Хотя предпринимательская деятельность связана с удовлетворением общественных потребностей, предприниматель принимает на себя имущественный риск не из благотворительных побуждений. Побудительным мотивом предпри-

1 Тарануха Ю.В. Предприятие и предпринимательство в трансформируемой экономике.М.: Издательство «Дело и Сервис», 2003.-368 с. 
нимательской деятельности является материальный интерес - прибыль которая может быть получена в результате рыночного обмена, и является результатом лучшего применения ресурсов в процессе хозяйственного оборота.

Новаторство, ставшее символом предпринимательства в XX веке, как элемент присутствует в нем всегда, поскольку деятельность в условиях нестабильности и неопределенности требует от предпринимателя постоянной изобретательности и творческого подхода ${ }^{1}$. В этой связи особенно важно подчеркнуть, что с экономической точки зрения новаторство представляет собой не открытие $u$ не изобретение, а практическую реализацию предпринимательской идеи, точнее говоря, коммерцииализацию новых технических, технологических, организационных $и$ uных достижений. В этой связи новаторскую роль предпринимательства вряд ли правомерно ограничивать только нововведениями, как полагал Й. Шумпетер. Она обязательно включает в себя распространение нововведений.

Изобретатель еще не новатор. Он становится таковым лишь тогда, когда реализует себя как предприниматель, то есть лицо, борющееся за лучшие результаты хозяйствования. Во-первых, лучший способ преодоления рыночной неопределенности - это изменение самой рыночной ситуации в выгодном для себя направлении, что возможно только посредством инновационной деятельности. Во-вторых, приобретение устойчивых рыночных преимуществ возможно также только посредством нововведений. Поэтому действительной причиной, понуждающей предпринимателей к новаторству, является конкуренция между ними. Новаторство, один их главных признаков предпринимательства, дающих ему возможность взаимодействовать с окружающей средой. Не интуиция и способность предугадать реакцию рынка, а созидательная деятельность по изменению самих рыночных условий становится определяющим фактором предпринимательства.

Как форма проявления творческого потенциала личности, новаторство, безусловно, связано с человеческим фактором. Однако как бы сильно не зависела склонность к новаторству от личностных качеств человека, как явление экономической жизни новаторство, прежде всего, обусловлено характером предпринимательской деятельности.

Таким образом, экономическое содержание новаторской функичи предпринимательства, заключается в расширении рыночного спроса.

Предпринимательство, как особый вид хозяйственного поведения реализовывает свои свойства ${ }^{3}$ (инициатива, риск, комбинирование и новаторство в условиях конкурентного взаимодействия хозяйствующих субъектов). Поэтому

${ }^{1}$ Шумпетер Й. Теория экономического развития. - М.: Экономика, 1989, С. 85-86.

2 Тарануха Ю.В. Предприятие и предпринимательство в трансформируемой экономике.М.: Издательство «Дело и Сервис», 2003.-368 с.

${ }^{3}$ Когда речь идет о явлении хозяйственной жизни, следует акцентировать внимание не на стоящих за ним личностях и выполняемых ими функциях, а на его собственной природе. В этой связи следует воспользоваться подходом К. Маркса, который совершенно справедливо отделял личностный аспект предпринимательства от самого явления, указывая, что собственно предпринимательская функция выполняется самим капиталом, в то время как предприниматель-капиталист всего лишь выполняет чисто управленческие функции, повинуясь внутренней логике движения капитала, единственная цель которого - расти (Маркс. К. Капитал Т.1, Маркс К., Энгельс Ф. Соч.Т.23). 
содержательный момент предпринимательской деятельности будет проявляться не только в завоевании приимуществ, но и в создании для себя лучших условий хозяйствования (главная специфическая черта предпринимательства как типа хозяйственного поведения). Результатом будет предпринимательская выгода как отражение реализованных конкурентных приимуществ.

В этой связи предпринимательство наиболее правильно определять как процеесс воздействующий на материальную культуру. В силу своего новаторства и посредством использования новых технологий создаются новые товары и стимулируются новые потребности.

В некоторых работах предпринимательство противопоставляется хозяйственной деятельности, что лишено здравого смысла. Ибо совершенно ясно, что вся хозяйственная деятельность не может быть новаторством т.к. новаторство выступает формой проявления накопленных результатов в процессе хозяйственной деятельности, что в последствии генерирует идею.

В нашей стране термины «предпринимательство» и «бизнес» употребляются как синонимы - русское название бизнеса.

Терминологически отличие этих терминов состоит в том, что бизнес для своей деятельности использует нарушение рыночного равновесия вызванного предпринимательством. В этом случае, как результат реализованной инициативы, бизнесмен получит дополнительный доход. С течением времени, когда все большее количество бизнесменов внедрит новейшие технологии использует технологии предпринимателя, рынок выровняет условия для производства и обращения и в соответствии с законом полезности, дополнительный доход будет сокращаться. Снижение доходов заставляет бизнесменов проводить диверсификацию, способствуя восстановлению рыночного равновесия.

Таким образом, предпринимательство отличается от бизнеса только одним сущзественным свойством - новаторством, приводящим к нарущению рыночного равновесия.

Предпринимательство в широком смысле, в отличие от бизнеса встречается значительно реже, «предприниматель, остающийся таковым» на протяжении десятилетий, встречается так же редко, как и коммерсант, который никогда в обычной жизни не бывал хоть немного предпринимателем» ${ }^{1}$ т.е. мы имеем дело с бизнесом. Бизнесмен может всю жизнь заниматься бизнесом и не быть предпринимателем, однако вся рыночная экономика без предпринимательства как соииально-экономического феномена сущуествовать не может.

В обиходе допускается равнозначность, этих терминов ибо узкий термин «предпринимательство» соответствует термину «бизнес» в широком смысле этого слова. В конкретном случае, когда речь идет о принципиальном различии между этими понятиями необходимо это уточнять. Итак, предпринимательство - это особый вид хозяйственной деятельности, суть которой заключается в стимулировании и удовлетворении спроса общества на конкретные потребности 
его членов, посредством рыночного обмена и направленной на завоевание конкурентных преимуществ через нарушение рыночного равновесия ${ }^{1}$.

В соответствии с принятой структурой процесса воспроизводства (производство, обмен, распределение, потребление) выделяют четыре главных сферы предпринимательства: производственная, коммерческая, финансовая и сфера потребления. Другие виды предпринимательской деятельности, например, инновационная, маркетинговая, включаются в состав четырех главных сфер предпринимательства ${ }^{2}$. Содержание предпринимательства, границы ее осуществления тесно связаны с формами и видами предпринимательской деятельности (табл. 1.1).

Таблица 1.1

Классификация предпринимательской деятельности

\begin{tabular}{|c|c|c|c|c|}
\hline $\begin{array}{c}\text { Признаки } \\
\text { классификации }\end{array}$ & \multicolumn{4}{|c|}{ Характеристика предпринимательской деятельности } \\
\hline $\begin{array}{l}\text { По сфере деятельно- } \\
\text { сти }\end{array}$ & $\begin{array}{l}\text { Производствен- } \\
\text { ная }\end{array}$ & Коммерческая & Финансовая & $\begin{array}{l}\text { Сфера } \\
\text { потребления }\end{array}$ \\
\hline \multirow{2}{*}{$\begin{array}{l}\text { По организационно } \\
\text { правовому статусу }\end{array}$} & $\begin{array}{l}\text { Без образования } \\
\text { юридического } \\
\text { лица }\end{array}$ & $\begin{array}{l}\text { Частное } \\
\text { предприятие }\end{array}$ & $\begin{array}{l}\text { Фермерское хозяй- } \\
\text { ство }\end{array}$ & $\begin{array}{l}\text { Общество с огра- } \\
\text { ниченной ответ- } \\
\text { ственностью }\end{array}$ \\
\hline & $\begin{array}{l}\text { Малое } \\
\text { предприятие }\end{array}$ & $\begin{array}{l}\text { Смешанное } \\
\text { товарищество }\end{array}$ & \begin{tabular}{|lr} 
Закрытое & или от- \\
крытое & акцио- \\
нерное общество
\end{tabular} & $\begin{array}{l}\text { Совместное пред- } \\
\text { приятие }\end{array}$ \\
\hline $\begin{array}{l}\text { По отношению к соб- } \\
\text { ствен-ности }\end{array}$ & $\begin{array}{l}\text { Индивиду- } \\
\text { альная (без при- } \\
\text { менения наем- } \\
\text { ного труда) }\end{array}$ & \multicolumn{2}{|c|}{ Частная } & Государственная \\
\hline $\begin{array}{l}\text { По количеству собст- } \\
\text { венников }\end{array}$ & $\begin{array}{l}\text { Индивиду- } \\
\text { альная, } \\
\text { частная } \\
\end{array}$ & Семейная & Коллективная & $\begin{array}{l}\text { Смешанная, } \\
\text { совместная }\end{array}$ \\
\hline $\begin{array}{l}\text { По масштабам произ- } \\
\text { водства и численно- } \\
\text { сти работников }\end{array}$ & $\begin{array}{l}\text { Малое пред- } \\
\text { прия-тие }\end{array}$ & \multicolumn{2}{|c|}{ Среднее предприятие } & Большое предприятие \\
\hline $\begin{array}{l}\text { По территориально- } \\
\text { му признаку }\end{array}$ & $\begin{array}{l}\text { Сельская, рай- } \\
\text { онная }\end{array}$ & $\begin{array}{l}\text { Городская, об- } \\
\text { ластная }\end{array}$ & $\begin{array}{l}\text { Региональная, нацио- } \\
\text { нальная }\end{array}$ & Зарубежная \\
\hline $\begin{array}{l}\text { По отраслевой при- } \\
\text { надлежности }\end{array}$ & $\begin{array}{l}\text { Строитель-ная, } \\
\text { тек-стильная }\end{array}$ & $\begin{array}{l}\text { Металло- } \\
\text { обрабатываю- } \\
\text { щая, горно- } \\
\text { добывающая }\end{array}$ & $\begin{array}{l}\text { Пищевая, } \\
\text { судостроительная }\end{array}$ & $\begin{array}{l}\text { Энергетика, } \\
\text { транспорт, } \\
\text { связь }\end{array}$ \\
\hline
\end{tabular}

Предпринимательская деятельность как продукт социально - экономического развития общества, требует постоянного и пристального внимания со стороны общества. Факты свидетельствуют, что даже в странах с развитой рыночной эко-

${ }^{1}$ Изменение в трактовках понятия «предпринимательство» необходимо рассматривать только в процессе исторического развития рыночного хозяйства, которое накладывало определенные акценты в содержательную часть термина «предпринимательство».

${ }^{2}$ Подробнее см.: Асаул А.Н. Предпринимательская деятельность в строительном комплексе (экономические проблемы).-СПб.: ИСЭП РАН, 1996.-236 с. 
номикой связи между государством и предпринимательством не всегда доброжелательны. И поэтому в целях поддержки предпринимательства возникают негосударственные общественные профессиональные организации

которые могут опосредованно влиять на управление экономикой регионов, а иногда и стран.

Общественные профессиональные организации выступают объединяющими органами для разрозненных, самостоятельно действующих предпринимательских организаций в одной или родственных областях экономики.

Так, например в Санкт-Петербурге в строительной отрасли работает более 30 общественных профессиональных организаций (союзы: архитекторов, реставраторов, стекольщиков, производителей сухих смесей и др., ассоциаций, проектных организаций, домостроителей и др.). Особенное влияние на деятельность инвестиционно-строительного комплекса (ИСК) оказывают общественные некоммерческие профессиональные организации: Союз строительных объединений и организаций (ССО), Союз строительных компаний, «Союзпетрострой». Основная задача направлена на установление плодотворных контактов между участниками ИСК, представление интересов организаций, работающих в ИСК региона, в органах государственной власти, вынесение на общественные слушания проектов и решение возникающих проблем и создание положительного имиджа Петербургского ИСК.

Новым формам негосударственной поддержки предпринимательства посвящена пп. 3.1, 5.3 и 5.4.

Во всех промышленно развитых странах правительственной поддержкой пользуется малое предпринимательство. В странах, где стороны государства отсутствует поддержка предпринимательства со стороны государства, развивается в основном, так называемое, уличное предпринимательство.

Суть государственной (правительственной) поддержки малых предприятий сводится чаще всего к выработке конкретных мер по трем направлениям:

консультационное сопровождение процесса создания и функционирования новых фирм на начальном этапе (1-3 года с момента образования фирмы);

оказание определенной финансовой поддержки вновь создаваемой структуре или предоставление такой структуре определенных льгот (обычно в сфере налогообложения);

оказание технической, научно-технической или технологической помощи маломощным в финансовом отношении предпринимательским структурам.

Государственной поддержкой охватываются обычно создаваемые предпринимательские структуры до момента их перехода из малых в категорию крупных предприятий.

В экономике России поддержка малого предпринимательства в производственной сфере государством, осуществляется в различных формах:

а) создание системы информационного обеспечения, обучения и переподготовки кадров, нормативной базы, финансовой инфрастуктуры и т.п.;

б) налоговые льготы и послабления; 
в) целевые фонды, финансирование из федерального и местных бюджетов, зарубежная финансовая помощь на поддержку предпринимательских структур в России.

В современной учебной и научной литературе предпринимательская деятельность, как правило, рассматривается в узких рамках - деятельность индивидуального предпринимательства. Однако принципы предпринимательской деятельности могут и должны использоваться и в государственном (общественном) секторе экономики.

Не вдаваясь в подробности, можно говорить о двух видовых фрормах предпринимательской деятельности: частной и государственной ${ }^{1}$.

Государственное предпринимательство ${ }^{2}$, есть форма осуществления хозяйственной деятельности, при которой принятие стратегических решений в отношении целей и способа предпринимательской деятельности принадлежит государству, а использование ее результатов имеет не частный характер. Реализуется государственное предпринимательство через:

a) государственные органы управления, которые уполномочены (в соответствии с действующим законодательством) управлять государственным имуществом (государственное предприятие) или б) органами местного самоуправления (муниципальное предприятие).

Частное предпринимательство есть форма осуществления предпринимательской деятельности, основывающейся на частной собственности и осуществляющаяся частными лицами в своих интересах. Это наиболее распространенная форма предпринимательства, имеющая многовековую историю, содержательным моментом которой является улучшение собственного хозяйственного положения. В некоторых случаях интересы частного предпринимательства могут противоречить интересам общества.

По способу организации частное предпринимательство может иметь индивидуальную, коллективную и корпоративные формы.

Характерным признаком частного предпринимательства является социальноэкономическая неоднородность его носителей. Реализовываться предпринимательская деятельность может на базе: а) личного труда - предприниматель без образования юридического лица или членов его семьи - фермерство, группы физических лиц - кооперативы; б) посредством применения наемного труда - коммерческие организации. Экономическая мотивация для них тоже будет разной для индивидуального и семейного предпринимателя - получение дохода, а для коммерческой организации получение прибыли.

Конечно, каждый из этих видов - государственное и частное предпринимательство - имеет свои отличительные признаки, но основные принципы их осуществления во многом совпадают. И в том, и в другом случае занятие такой

${ }^{1}$ Имеется в виду не столько тот факт, что государство выступает в качестве предпринимателя, сколько обстоятельство, что государственные или общественные предприятия функционируют на принципах предпринимательства.

2 По некоторым оценкам, государству принадлежит до половины всех имеющихся в стране активов, в том числе более или менее крупные пакеты акций в приватизированных предприятиях. 
деятельностью предполагает инициативность, инновационный подход, комбинирование факторов производства в условиях конкуренции. Схожей является и типология обоих видов предпринимательства.

Основное отличие государственного предпринимательства от частного состоит в том, что государство ставит перед своими предприятиями, помимо коммерческих, определенные социально-экономические цели. Рыночные показатели результатов деятельности (прибыльность и рентабельность) не являются для них универсальным критерием эффективности, поскольку их цель часто формируется под влиянием государственной политики и соответствует оптимальности участия государства в предпринимательской деятельности.

У государственного предпринимательства существуют свои специфические потенциальные источники сверхприбыли, обусловленные относительно крупными размерами госпредприятий, авторитетом и экономической мощью государства. В этой связи на первый план выходят не столько рисковые моменты (в максимальной мере представленные в малом предпринимательстве), сколько такие факторы, как:

1) значительные и стабильные объемы закупок сырья, материалов, комплектующих и т.п., предполагающие льготные параметры оплаты и скидки;

2) доступность кредитов на особо выгодных условиях;

3) экономия на масштабах производства;

4) широкие возможности получения нового оборудования, включая лизинговые;

5) устойчивая сеть деловых связей, приобщенность к источникам исчерпывающей информации о потенциальных рынках сбыта, партнерах, в том числе зарубежных.

Эти преимущества государственных коммерческих предприятий как субъектов рыночных отношений могут являться основой для снижения их индивидуальных издержек по сравнению с общественными и тем самым - для извлечения сверхприбыли.

Конечно, можно говорить о коллективном, семейном и ином предпринимательстве, но все это будут производные от двух указанных форм. 


\section{3. Сущность предпринимательства}

Сущность предпринимательства как особой формы хозяйствования не возможно раскрыть, не уяснив его содержания сути его носителя. Проблемы носителя предпринимательства связаны с различиями в трактовках самого понятия «предпринимательство».

Предприниматели, согласно определению Й. Шумпетера, - это хозяйственные субъекты, функцией которых является, осуществление новых комбинаций и которые выступают как активные субъекты предприятия ${ }^{1}$. При этом Й. Шумпетер полагает, что традиционное ограничение круга предпринимателей только лишь «самостоятельными субъектами» (частными лицами), в принципе, неверно. К предпринимателям следует относить всех, кто выполняет названную функцию, в том числе работников организации, а также и тех, кто реализует инновационную функцию импульсивно, эпизодически: экономистов, финансистов, юристов, консультантов и пр.

Статусный аспект идентификации предпринимателя Й. Шумпетером, не только не принимается в расчет, но представляется Шумпетеру принципиально неверными ${ }^{2}$. Существенным оказывается только функциональный аспект идентификации. В качестве предпринимателя признается только, лицо осуществляющее инновацию (новую комбинацию), и оно перестает быть таковым, как только учрежденное им «дело» начинает дальше функционировать как стабильная система.

Предпринимательство, по мнению Й. Шумпетера, не может рассматриваться как профессия, т. к. в этом статусе невозможно находиться длительное времяз Также весьма условным является и идентификация предпринимателей как класса - данная группа не имеет собственной классовой позиции, правда, предпринимателей отличает особый стиль жизнич

Особенностью предпринимателей как общественной группы является ее принципиальная немногочисленность. Предприниматели - это особый тип склонных к инновационной деятельности людей, которых всегда меньшинство. Большинство никогда не является способным к инновационной деятельности ${ }^{5}$.

${ }^{1}$ Шумпетер Й. Указ. соч. С. 169-170.

2 «Право собственности на промышленное предприятие или вообще на любое «имущество» не является для нас существенным признаком предпринимателя» (Шумпетер Й. Указ. соч. С. 170). «Не только крестьяне, ремесленники, представители свободных профессий, порой причисляемые к «предпринимателям», но и «фабриканты», «промышленники» и «коммерсанты», всегда попадающие в эту группу, с нашей точки зрения, вовсе не обязательно являются «предпринимателями» (Шумпетер Й. Указ. соч. С. 171).

${ }^{3}$ «...предприниматель, остающийся таковым" на протяжении десятилетий, встречается так же редко, как и коммерсант, который никогда в жизни не бывал хоть немного предпринимателем» (Шумпетер Й. Указ. соч. С. 174).

${ }^{4}$ Шумпетер Й. Указ. соч. С. 175.

${ }^{5}$ Шумпетер Й. Указ. соч. С. 177-183. 
Анализируя природу носителя предпринимательства, мы видим, что в зависимости от предпринимаемых в качестве сущностных черт предпринимательства, определяется и его субъект. Если новаторство, то менеджеры, а если риски, то собственники.

С развитием корпоративного предпринимательства, которое принципиально отличается от классического тем, что если в эпоху традиционного капитализма предприниматель (владелец капитала) был ключевой фигурой экономического поля, то теперь держателей акций, по мнению Дж. Гэлбрейта, отстранила от процесса управления «техноструктура» - высший менеджмент и специалисты, организующие деятельность предприятия ${ }^{1}$. При этом власть в эффективно функционирующей корпорации, практически, не принадлежит одному человеку, что было характерно для предшествовавших эпох. Напротив, потребности управления корпорацией требуют распределения власти между достаточно большим числом представителей менеджеров.

По своим деловым качествам, ценностям, корпоративным нормам поведения менеджеры представляют собой противоположность индивидуальным предпринимателям. Им чужды индивидуализм, жесткость, способность рисковать, соперничество и властолюбие. Напротив, им присущи стремление работать «в команде», коллективизм, осознание ценности сотрудничества. Принципиально отличны и интересы предпринимателей и менеджеров. Индивидуальный владелец капитала, как правило, стремился к получению максимальной прибыли. Для менеджеров гораздо важнее сохранение условий получения стабильного дохода и гарантии сохранения своего социального положения. Поэтому в процессе управления корпорацией высший менеджмент стремится отстранить владельцев капитала (акций) от процесса принятия решений, обосновывая данную тенденцию их некомпетентностью.

Таким образом, высший менеджмент, (по Дж. Гэлбрейту - техноструктура), функционально фактически заменил предпринимателей эпохи традиционного капитализма. Более того, процесс этот зашел так далеко, что если на начальном этапе формирования «нового индустриального общества» представители технострукутры стремились; подражать своим обладающим капиталом боссам, то ныне этого уже не наблюдается. «Можно почти с уверенностью сказать, что стремление рядиться в тогу классического предпринимателя - это явление, уходящее в прошлое. Молодое поколение администраторов приемлет тот факт, что они работают в рамках организации, и вытекающие отсюда требования, относящиеся к их поведению. Сознание взаимной зависимости в этой среде налицо» ${ }^{2}$.

Таким образом, в новых экономических условиях мы наблюдаем рассредоточение предпринимательской функции в процессе развития производства и, как следствие усложнение предпринимательской функции.

Современные условия хозяйственной деятельности, требуют не просто специальных знаний и специализации функций, но и рассредоточения самой предпринимательской функции в виде расчленения процесса принятия решений. В корпо-

\footnotetext{
${ }^{1}$ Гэлбрейт Д. Экономические теории и цели общества.-М., 1976.-С. 118-120.

${ }^{2}$ Гэлбрейт Дж. Новое индустриальное общество. М.1969.С138
} 
ративном предпринимательстве часть решений, в том числе стратегического характера, передана высшему менеджменту, в деятельность которой собственник вмешивается в случае крайней необходимости. Параллельно создается сложный механизм контроля за деятельностью управленцев, причем как со стороны собственника, так и со стороны общества. В свою очередь часть управленческих функций передается администрацией на более низкие этажи управления, что сопровождается созданием сложных систем стимулирования и контроля. В результате формируется достаточно жесткий механизм контроля за деятельностью всех участников, а предпринимательская функция становится все более распыленной и регулируемой. Кого же в этом случае мы можем назвать субъектом предпринимательства?

Быть носителем предпринимательства - значит обеспечивать реализацию фундаментальной функиии предпринимательства, т.е. ключом к решению данного вопроса является характер реализации предпринимательской функции, а не персонификация какого-либо признака предпринимательства, пусть даже доминирующего. В случае, когда пучок правомочий в отношении принятия решений сконцентрирован у собственника, то непосредственным носителем предпринимательства будет он. Когда же такой пучок рассредоточен по разным уровням управления, и реализация предпринимательской функции становится возможной только при условии мобилизации усилий всего коллектива, тогда предпринимательство становится уделом коллективной деятельности, носителем которой выступает коммерческая организация ${ }^{1}$. Принятие коммерческой организации в качестве носителя современного предпринимательства отнюдь не означает изменения его природы или содержательной стороны, а свидетельствует всего лишь об изменении модели осуществления предпринимательства 2 .

Рассредоточение предпринимательской функции в виде распределения процесса принятия решений и вовлечение в предпринимательский процесс все большего числа участников является объективным условием современного предпринимательства. Предпринимательство становится уделом коллективной деятельности, а его носителем выступает коммерческая организация. В связи с этим распределение прав собственности является объективным процессом и условием эффективного осуществления предпринимательской деятельности.

Поскольку важнейшие, с точки зрения осуществления предпринимательства, составляющие пучка прав собственности (организация и ликвидация предприятия, постановка целей, право окончательного контроля, право на остаточный доход) закрепляются за собственником, то, независимо от организационной формы осуществления предпринимательства, ее следует понимать как деятельность, реализующуюся, посредством управления в интересах собственника. Эффективная предпринимательская деятельность невозможна без мотивации наемных работников.

${ }^{1}$ Варнеке Х.Ю. Революция в предпринимательской культуре - М., 1999 С. 182-190

2 Тарануха Ю.В. Предприятие и предпринимательство в трансформируемой экономике.М.: Издательство «Дело и Сервис», 2003.-368 с. 
Мотивация - процесс направленный на побуждение человека к деятельности, результатом которой является достижение личной, коллективной или общественной цели - важнейшая составляющая организации современного предпринимательства.

Практически все предшественники Й. Шумпетера видели в качестве ведущих мотивов предпринимательской деятельности прибыль. Й. Шумпетер одним из первых представил развернутую трактовку неэкономических мотивов предпринимательства и выделил три основные группы таких мотивов':

1) стремление иметь «свою империю» - быть полновластным господином в собственном предприятии, которое предприниматель сам конструирует и сам строит и которое, в случае успеха, полностью отвечает его запросам, потребностям, ценностям.

2) воля к победе - возможность в рамках собственного «дела» доказать собственную состоятельность, проявить мужество, ум, стойкость в борьбе с конкурентами и другими факторами среды, реализовать себя как личность.

3) радость творчества - возможность заниматься любимым делом, полностью соответствующим индивидуальным интересам и установкам, возможность видеть конкретные результаты собственных усилий. При этом ключевыми в мотивации предпринимателя являются не факторы результата деятельности (полученный доход, общественное признание, статус и т. п.), а факторы процесса предпринимательской деятельности (поиск нового, возможности для проявления личностных качеств, борьба и преодоление препятствий на пути к успеху и т. д.).

Мотивация участников предпринимательской деятельности в коммерческой организации, как одна из функций и методов управления является ситуационным фактором внутренней среды предпринимательской организации. Аспекты ее решения могут быть разными: контроль и стимулирование, управление в т.ч. и предпринимательская культура и т.п.

Экономическая мотивация, как фактор развития предпринимательства, представляет собой прочесс согласования экономических ичелей, которые ставят перед собой и предприниматели и наемные работники при организации и ведении производственно-хозяйственной деятельности.

Формой участия субъекта предпринимательской деятельности в хозяйственной деятельности является его экономическая активность - целесообразная деятельность человека в экономических процессах, направленная на получение «чистой» (т.е. превышающей затраты) выгоды.

Поскольку экономические процессы в рыночной экономике - это результат множества актов выбора человеком способа достижения «чистой» выгоды, то соответственно в случае отсутствия выбора будет наблюдаться и отсутствие рыночной экономики. Здесь следует остановиться на том, что рыночное понимание «выбора выгоды» шире, чем только желание денежной выгоды (прибыли). Под этим термином понимается и возможность выбора сферы приложения капитала, сферы и формы конкуренции, выбора при изобилии предложения - словом выбора по

${ }^{1}$ Шумпетер Й. Указ. соч. С. 193 
всему набору возможностей, предоставляемых рыночной экономикой ее участнику и прежде всего - потребителю.

Как известно, рыночная экономика базируется на таких основополагающих принципах ${ }^{1}$ :

1.Экономическое самоопределение личности. Это - основа основ рыночной организации общественного производства, ибо означает право на личную свободу человека, самостоятельное улучшение своей жизни. Этот принцип создает и постоянно обеспечивает (и воспроизводит) равные шансы на рыночную активность для всех участников рыночной экономики и условие раскрытия творческого потенциала. Экономическое самоопределение личности это право человека на экономическую самодеятельность во всех ее формах, в том числе и на предпринимательскую.

2.Право быть собственником всех видов имущеества. Собственность в условиях рыночной экономики - это не гарантия беззаботного существования, а бремя имущественной ответственности за результаты коммерческого использования своей собственности, это необходимость ее постоянного рыночного воспроизводства. Право быть собственником возможно при гарантии обществом защиты, поддержки и равноправия всех видов и форм собственности, право на коммерческое применение объектов собственности и доходов от такого применения.

3. Равенство экономических прав любых юридических и физических лиц на ведение хозяйственной деятельности способно постоянно воспроизводить необходимое условие рыночной организации производства - ее открытость, многосекторность и обусловленную этим конкуренцию.

4. Экономическая свобода товаропроизводителя, выражается в его праве на самостоятельное определение объема и структуры своего производства, ассортимента продукции и объема ее реализации, установление цены на нее и выбора партнеров. Любая попытка внеэкономического ограничения экономической свободы товаропроизводителей противоречит природе рыночной экономики.

5. Распространение коммерческих принципов по «вертикали» и по «горизонтали», когда все сферы и все уровни экономики «пронизаны» рыночными отношениями и взаимодействующие по единым рыночным правилам.

6. Свободное ценообразование 2 . Одновременное воздействие на цену множества ценообразующих факторов (затраты труда и производства, издержек обращения, спроса и предложения, доходов и объема инвестиций) придает ценам ту непредсказуемость, которая и превращает рынок в повседневный экзамен и бесконечное состязание между всеми участниками экономического процесса. Именно эта непредсказуемость вынуждает товаропроизводителей к постоянному совершенствованию организации производства, минимизации его затрат, повышению качества, новаторству и риску.

7. Наличие рынков труда, товаров и капиталов, движение которых придает необходимый рыночной экономике импульс.

${ }^{1}$ Современная экономика. Общедоступный учебный курс. Ростов н/Д.: изд-во «Феникс», $1998-$ C. $23-26$

${ }^{2}$ Административное назначение цен допускается только в нерыночных секторах экономики (наука, образование, здравоохранение, оборона, экология и др.). 
8. Государственное регулирование рыночной экономики, включающее следующие главные направления: стабилизацию производства («налоговая и инвестиционная политика»); финансирование научно-технического прогресса («политика научно-целевых программ»); дотацию социально значимых отраслей («инвестиционная политика»); выравнивание уровней экономического развития различных регионов («региональная экономическая политика»); государственную поддержку конкуренции («политика демонополизации»); оздоровление денежной системы («финансовая и антиинфляционная политика»); преодоление чрезмерной имущественной дифференциации населения («политика доходов»).

9. Система социальной защчиты - главное средство ослабления неизбежных негативных социальных последствий рыночной экономики.

Система социальной защиты включает три главных направления: регулирование доходов предпринимателей посредством их налогового перераспределения; гарантию заработной платы наемных работников с помощью законодательного утверждения минимальной заработной платы как обязательной базы оплаты труда; защиту уровня жизни населения путем индексации заработной платы и других фиксированных доходов.

Если рассматривать экономическую активность человека, осуществляющую в рамках экономического процесса с точки зрения функционального подхода то мы видим, что форма проявления экономической активности есть предполагаемые (до востребования) возлагаемые (в момент вступления) или исполняемые (в ходе, в течение экономического процесса) функиии, функииональные обязанности.

Осуществление экономической активности человека возможно в двух ипостасях: в качестве наемного работника, и в качестве предпринимателя и каждая из них имеет свои особенности. Нас же в рамках рассматриваемой проблемы интересует именно предприниматель, как субъект предпринимательской активности.

Предпринимательская способность субъекта предпринимательства не ограничивается энергией предпринимательской активности и обязательно дополняется образованием, опытом, знаниями, навыками и умениями предпринимателя. Однако без самоорганизации - умения совершать последовательные, логически связанные и целенаправленные действия, на реализацию основной предпринимательской функции - новации - предприниматель состояться не может т.е. функция субъекта предпринимательства напрямую связана с самоорганизацией.

К основным, исходным положениям самоорганизации относятся:

генерирование идеи;

планирование, т.е. трансформация идеи в товар (работу, услугу);

принятие предпринимательского решения о реализации предпринимательского проекта;

создание предприятия, как имущественного комплекса, в рамках организационно-правовой формы и определение статуса своего участия в реализации предпринимательского проекта;

инвестирование (финансовое обеспечение предпринимательского проекта);

управление предприятием

оценка эффективности предпринимательской деятельности. 
Предпринимательская идея представляет собой выявленный возможный интерес фирмы-производителя, имеющий видимые очертания какой-либо конкретной экономической формы. Выявление такого интереса может осуществляться посредством совмещения возможностей предпринимателя с потребностями рынка, или, наоборот, путем совмещения потребностей рынка с возможностями предпринимателя.

Выступая в качестве особого вида экономической активности, предпринимательство на начальном этапе связано, только, лишь с идеей - результатом мыслительной деятельности, впоследствии принимающей материализованную форму.

Предпринимательство характеризуется обязательным наличием инновационного фактора. Инновация - нечто, воспринимаемое как новое, как нововведение. Нововведение - процесс, в ходе которого изобретение или открытие доводится до стадии практического применения и начинает давать экономический эффект, новое приложение научно-технических знаний, внедрение нового производственного метода или применение новой формы организации бизнеса, обеспечивающих рыночный успех, запуск в производство нового продукта, Под новшеством понимается новая система управления производством, качеством, внедрение новых методов организации производства или новых технологий - это тоже инновационные моменты.

В предпринимательстве принято рассматривать два основных элемента:

новаторскую инновационную деятельность как предпринимательскую функцию;

действия предпринимателя как носителя и реализатора данной функции (рис. $1.3)$.

Новаторская инновационная деятельность как последовательная цепь событий от новой идеи до ее реализации в конкретном продукте или технологии и дальнейшее распространение нововведения представляет собой следующие этапы.

Первый - отбор новых идей, знаний, новых продуктов, услуг, операций, принципов организации, как результат законченных научных исследований (фундаментальных и прикладных), опытно-конструкторских разработок, иные научнотехнические результаты, т.е. новащий.

Bторым является внедрение, введение новации в практическую деятельность, т.е. нововведение (инновация).

${ }^{1}$ От англ. Innovation - введение нового. 


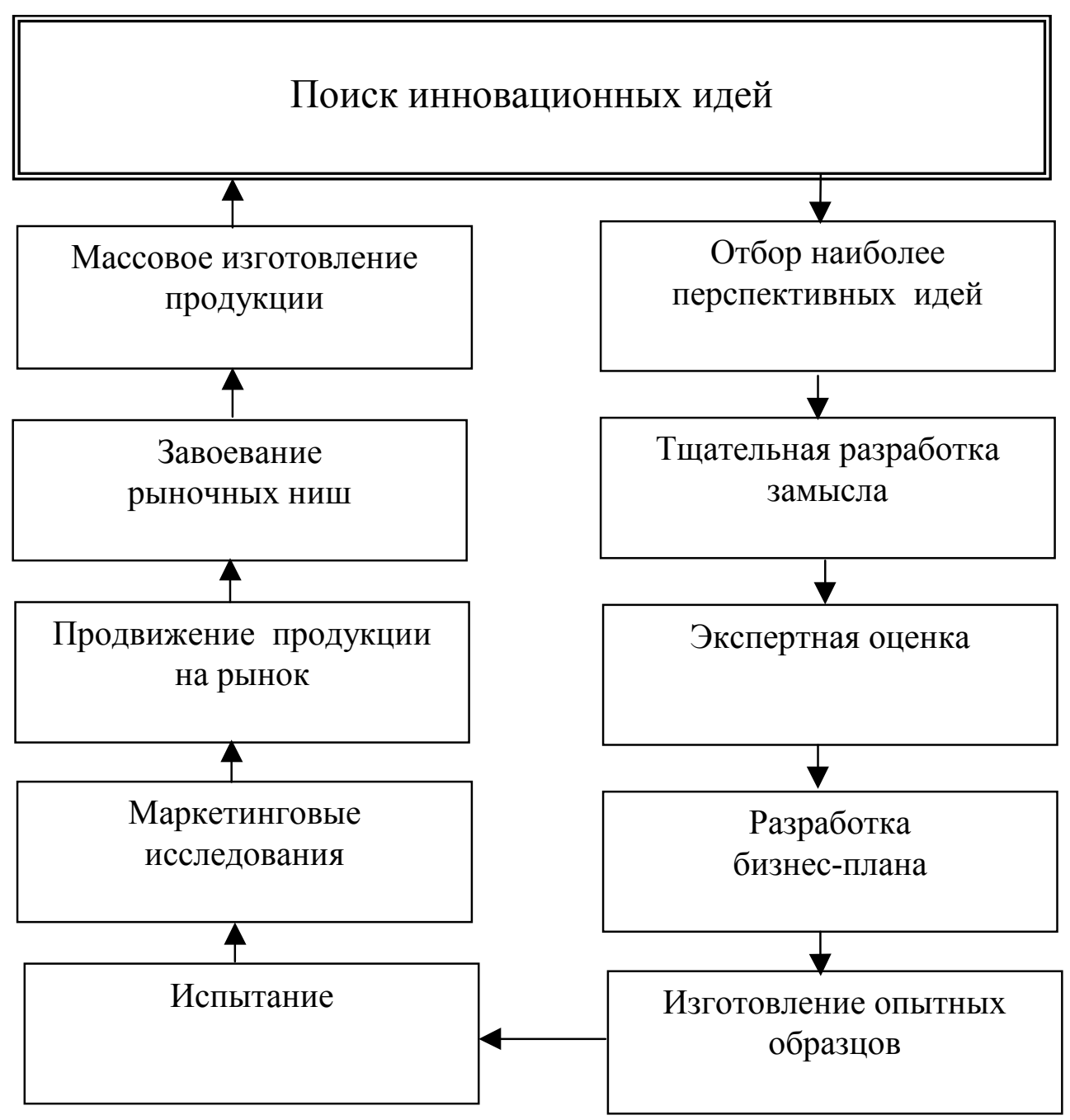

Рис. 1.3. Действия предпринимателя при разработке новшеств

Третьим этапом является диффузия инноваций, под которой подразумевается распространение уже однажды освоенной, реализованной инновации, т.е. применение инновационных продуктов, услуг или технологии в новых местах и условиях.

Идеи могут быть как собственные, так и заимствованные.

Генерирование собственных идей или заимствование чужих - предполагает создание предпринимательского проекта, в котором разработан алгоритм действий предпринимателя.

Обязательной составной частью предпринимательского проекта является технико-экономические обоснования (бизнес-план) трансформации идеи в предприятие, позволяющее реализовать идею. Поскольку в основе любой идеи всегда лежит конкретный продукт (товар, работа или услуга) который может быть востребован рынком, то в случае если на рынке предлагаемый продукт не востребован, то соответственно и идея будет не реализована. Для определения востребованности продукта идеи и состоятельности проводятся экспертные оценки. После генерирования предпринимательской идеи, на первом этапе предприниматель экспертирует свою идею на предмет совместимости идеи с возможностями предпринимателя самостоятельно. 
В случае невозможности совместить требования, соответствующие характеру и качеству идеи, со своими возможностями, предприниматель принимает решение об отказе реализации собственными силами и прорабатывает варианты коммерческого использования предпринимательской идеи.

В случае если первая экспертная оценка идеи положительна, то, как правило, для второй экспертизы приглашаются внешние эксперты. В этом случае изучается деловая среда, на предмет совместимости предпринимательской идеи с внешней средой и возможные формы ее реализации (индивидуальное предпринимательство, создание предприятия, интрапренерство и т.д.).

В случае выхода на рынок, предприниматель затрагивает чьи-то интересы, поэтому всегда необходимо просчитывать риски присущие как предпринимательской идее, так и процессу ее реализации в конкретной внешней среде предпринимательской деятельности. О сути предпринимательских рисков, факторах и методах снижающих риск рассматривается в 1.4.

Для принятия предпринимательского решения необходимо иметь информацию о соотношении на конкретном рынке между спросом и предложением продукта который заложен в предпринимательском проекте. Выявление соотношения между спросом и предложением продукта дает возможность предпринимателю принять решение о целесообразности реализации идеи. Если анализ показывает, что спрос на данный товар превышает предложение, то составляется бизнес план с точными расчетами потребностей в ресурсах и выявление эффекта от реализации экспериментальной идеи.

После определения размера первоначального (стартового) капитала т.е. тех финансовых вложений без осуществления которых процесс реализации идеи не возможен, осуществляется выбор инвестора.

В случае, когда предприниматель реализующий предпринимательскую идею является инвестором то сложностей в выборе организационно-правовой формы коммерческой организации не предвидится. Если же инвестор привлекается со стороны, то необходимо согласовать степень участия предпринимателя и инвестора, а также их статус. В случае необходимости, оценивается интеллектуальный капитал (в виде предпринимательской идеи) вкладываемый в создание предприятия. Далее определяется форма инвестирования ресурсов, выявляются потребности в формировании оборотного и основного капитала и оценка инвестиционного проекта.

Перед принятием предпринимательского решения о реализации рассматриваемой идеи обязательно проводится экспериментальная оценка полученной информации. В случае психологического убеждения предпринимателя в адекватности имеющейся информации предприниматель принимает решение на ментальном уровне, о целесообразности реализации идеи. Но возможны и другие решения: отказ от использования идеи или отсрочка начала реализации проекта до решения определенных условий или обстоятельств.

Последовательность вероятных действий предпринимателя от зарождения идеи до принятия предпринимательского решения отражена на рис. 1.4. 


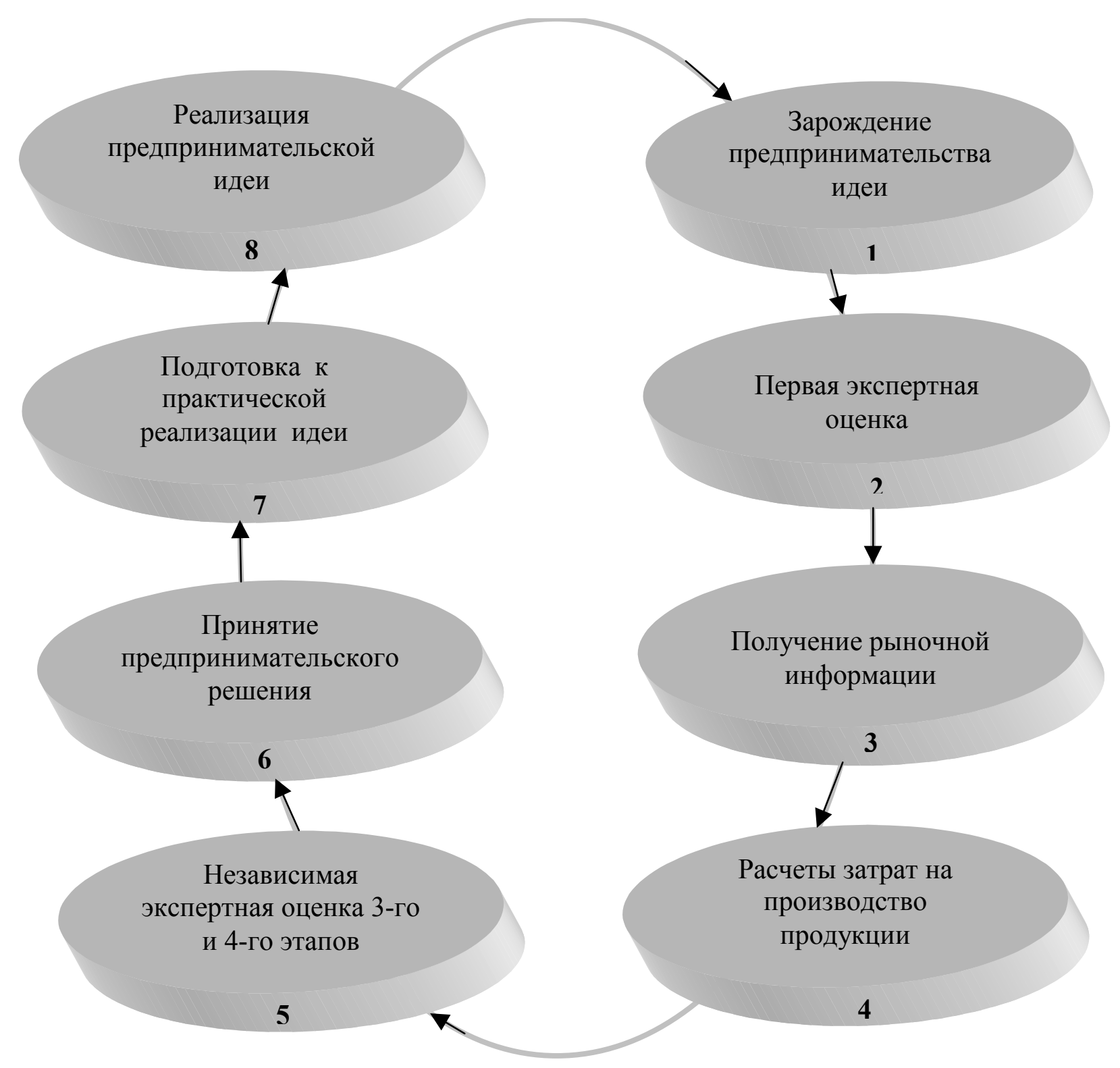

Рис. 1.4. Жизненный цикл предпринимательской идеи

Далее предприниматель реализует бизнес-план, с соблюдением очередности определенных им действий. Создание предприятия предполагает формирование условий, наличие которых позволяет предпринимателю реализовывать свою идею. Одной из форм образования основных средств является лизинг.

Создание предприятия предполагает необходимость профессионального управления им. В случае если предприниматель сам выполняет эти функции, то он выступает в качестве менеджера. Чаще всего предприниматель выполняет функции технического руководителя, а руководство предприятием передается профессиональным, наемным менеджерам.

Соизмерение затрат и результатов позволяет оценить эффективность работы предприятия. В сопоставлении этих факторов закладывается экономическая суть хозяйственной деятельности. ${ }^{1}$ Как известно прибыль определяет уровень до-

1 Подробнее см. Асаул А.Н., Асаул Н.А. Учет затрат и формирование себестоимости продукции на малых предприятиях / Экономика строительства. М. 2000. 
стижения поставленной цели, а она определяется разностью дохода от продажи продукиии (работ, услуг) и затрат на их производство и сбыт, поэтому реализация предпринимательской идеи предполагает управление затратами как средство достижения предпринимателем высокого экономического результата. Управление затратами не сводиться только к снижению затрат, а распределяется на все элементы управления организацией ${ }^{1}$.

Любая предпринимательская деятельность должна быть эффективной по определению. Эффективность любой деятельности принято выражать с помощью отнесения результата к затратам. Целевая ориентация такого отнесения: максимизировать результат, приходящийся на единицу затрат. Основным принципом измерения эффективности является взаимосвязь цели и конечного результата предпринимательской деятельности.

Поскольку результат предпринимательской деятельности всегда связан с ее целью, атрибутом которой является стимулирование и удовлетворение спроса общества на конкретный продукт (товары, работы и услуги), то соответственно объектами предпринимательской деятельности являются изготовленная продукция, выполненная работа или оказанная услуга, т. е. то, что может удовлетворить чью-либо потребность и что предлагается на рынке для приобретения, использования и потребления. ${ }^{2}$

Товары и услуги, являющиеся продуктом предпринимательства, охватывают самый обширный спектр вещей, предметов, видов деятельности, в которых нуждаются люди, семьи, фирмы, государство. Это могут быть потребительские товары и услуги, средства производства, материальные и духовные ценности, информация, валюта, деньги, ценные бумаги, строительные и ремонтные работы, словом, все, на что потребители предъявляют спрос, за что они готовы выкладывать деньги.

${ }^{1}$ Подробнее см. Лебедев В.Г., Дроздова Т.Г., Асаул А.Н. и др. Управление затратами на предприятии. Учебник. Издательский дом «Бизнес-пресса», СПб. 2000.

2 Подробнее см. Багиев Г.Л., Асаул А.Н. Организация предпринимательской деятельности / Уч. пособие. СПб. СПбГУЭФ. 2001. 


\section{4. Нестабильность, неопределенность и риск в предпринимательской деятельности.}

Родовым признаком предпринимательства является рисковая деятельность, т.е. риск - постоянный спутник предпринимателя. И не потому, что предприниматель склонен к риску, а с его нацеленностью на обращение рыночной нестабильности и неопределенности в свою пользу в форме определенного вознаграждения. Последнее и выступает решающим фактором, вынуждающим предпринимателя идти на риск. Поэтому и величина принимаемого им на себя риска напрямую зависит от вероятного увеличения дохода. Коммерческий риск отличается еще и тем, что он основывается на трезвом расчете и учете возможных отрицательных последствий. Стремление к успеху здесь всегда уравновешивается хозяйственной ответственностью, степень которой в значительной мере определяет приемлемый для предпринимателя уровень риска - недополучение дохода, несение убытков, потерю собственности.

В современной отечественной хозяйственной практике понятия «риск», «нестабильность», «неопределенность», «анализ рисков», «управление рисками» появились недавно и в большей степени в приложении к финансовому рынку. Лишь последние несколько лет эти понятия объединив накопленный международный опыт и российскую теоретическую базу законодательно закреплены ${ }^{1}$ и стали обязательной составляющей любого бизнес-плана инвестиционного проекта.

Предпринимательская среда потенциально несет в себе нестабильность и неопределенность в отношении будущих событий и соответственно риск. Первопричиной такого потенциала является нестабильность.

В общем случае, нестабильность предполагает переход к неизвестному состоянию, затрагивающему устойчивость какой-либо системы в нашем случае предпринимательской. Шкала колебаний нестабильности достаточно велика, от изменений, результат которых можно предвидеть до изменений совершенно непредсказуемых.

Условия нестабильности являются дестабилизирующими по отношению к предпринимательской деятельности. Причинами нестабильности является непривычное поведение или изменение отдельных элементов предпринимательской среды.

Нестабильность:

приводит к потере устойчивости предпринимательской единицы, соответственно ухудшает количественные значения показателей, ее характеризующих;

изменяет структуру и качественный состав предпринимательской единицы;

ухудшает показатели управляемости предпринимательской единицы; преобразует предпринимательскую организацию в новую предпринима-

1 «Методические рекомендации по оценке эффективности инвестиционных проектов и их отбору для финансирования» утверждено: Министерство экономики РФ, Министерство финансов РФ, Государственный комитет РФ по строительной, архитектурной и жилищной политике № ВК 477 от 21.06.1999г. 
тельскую структуру (делит или ликвидирует ее) согласно принципам самоорганизации.

Нестабильность для предпринимательской организации, предполагает как негативные тенденции и рисковые ситуации, так и возможности для новых уникальных событий которые в свою очередь могут расширить спектр возможных предпринимательских решений.

Признание нестабильности поможет снизить риски и привести к рождению новых предпринимательских идей.

Предпринимательская деятельность осуществляется в условиях наличия той или иной меры неопределенности, определяемой следующими факторами:

неполным знанием всех параметров, обстоятельств, ситуации для выбора оптимального решения, а также невозможностью адекватного и точного учета всей даже доступной информации и наличием вероятностных характеристик поведения среды;

наличием фактора случайности, т. е. реализации факторов, которые невозможно предусмотреть и спрогнозировать даже в вероятностной реализации;

наличием субъективных факторов противодействия, когда принятие решений идет в ситуации игры партнеров с противоположными или не совпадающими интересами.

Неопределенность - неполнота или неточность информации об условиях реализации предпринимательской деятельности, в том числе связанных с ними затратах и результатах. Причем неполнота относится к объему информации. позволяющему полностью выяснить истинное значение характеристик. Неточность это расхождение между истинными и полученными в ходе наблюдения данными. Неопределенность не означает отсутствия информации, а только не указывает конкретного численного значения характеристик. Неопределенность предполагает наличие нестабильности, при которой результаты действий не обусловлены, а степень возможного влияния этих факторов на результаты неизвестна.

В условиях риска и неопределенности предприниматель не имеет точного представления о факторах внешней среды и их влияния на результат предпринимательской деятельности, который можно рассматривать как функцию условий - факторов внешней среды (функцию полезности). Предприниматель может только предвидеть результат своей деятельности, но для анализа имеющихся альтернатив и принятия решения можно использовать матрицу решений, называемую также платежной матрицей. Пример матрицы решений приведен в таблице 1.2 .

Таблища 1.2

Матрица решений

\begin{tabular}{|c|c|c|c|c|}
\hline \multirow{2}{*}{ Альтернативы } & \multicolumn{4}{|c|}{ Состояние экономики } \\
\cline { 2 - 5 } & $\mathrm{S}_{1}$ & $\mathrm{~S}_{2}$ & $\mathrm{~S}_{3}$ & \\
\hline $\mathrm{A}_{1}$ & & & & \\
\hline $\mathrm{A}_{2}$ & & & & \\
\hline $\mathrm{A}_{3}$ & & & & \\
\hline$\ldots$ & & & & \\
\hline
\end{tabular}


где $A_{1} A_{2}, A_{3}$ - альтернативы стратегии действий; $\mathrm{S}_{1}, \mathrm{~S}_{2}, \mathrm{~S}_{3}-$ состояние экономики (стабильность, спад, рост и др.).

Числа в ячейках матрицы представляют собой результаты реализации $A j$. стратегии в условиях $S j$. При этом, в условиях риска вероятность может быть определена субъективно, в зависимости от того, какой информацией располагает Л ПР.

Методы принятия решений в условиях риска используют теорию выбора, получившую название теории полезности. В соответствии с этой теорией, предприниматель выбирает $A j$. из совокупности $\{A j\}(j=1, \ldots, n)$, если она максимизирует ожидаемую стоимость его функции полезности Yij...

В условиях риска при принятии предпринимателем решения главным является определение вероятности наступления состояния среды $S j$., т. е. степени риска. После этого определяется ожидаемая стоимость реализации каждой альтернативы, представляющая средневзвешенную стоимость $E(x)$.

$$
E(x)=P_{r} x_{1}+P_{p_{2}} x_{2}+\ldots P_{n} x_{n}=\sum_{i=1}^{n} P_{i} x_{P}
$$

где хі - результат реализации Ај; Pi. - вероятность реализации Ај в условиях $S_{f}$

Оптимальной стратегией является та, которая обеспечивает наибольшую стоимость.

$$
\begin{gathered}
E(x)=\sum_{i=1}^{n} P_{i} x_{i} \Rightarrow \max \\
\Pi \text { ри } \sum_{i=1}^{n} P_{i}=1
\end{gathered}
$$

Кроме показателя $E(x)$ при принятии решений в условиях риска используют еще один критерий - степень отклонения ожидаемой стоимости от предолагаемых последствий, т. е. степень риска (г>), называемый коэффициентом вариации. Он определяется отношением среднего квадратичного отклонения к средней арифметической:

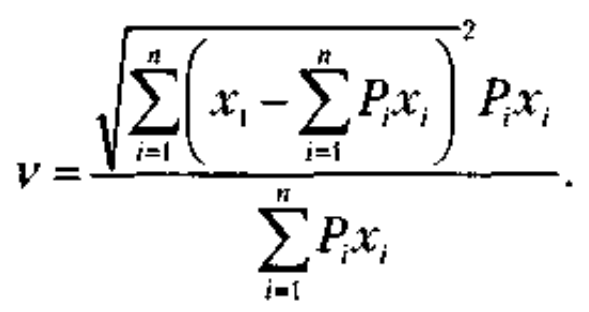


Коэффициент вариации вычисляется в процентах и характеризует показатель риска для каждой стратегии $A j .$. Чем выше значение коэффициента вариации, тем более рискованное решение предприниматель принимает.

В условиях риска осле определения предполагаемой стоимости $E(x)$ и степени риска и встает проблема определения компромисса между риском и прибылью. Как правило, получение больших доходов сопровождают более высокие значения степени риска, поэтому принимаемые предпринимателем решения будут зависеть не только от расчета показателей $E\{x)=2 \_{ }_{J} P_{i} x_{i}$, но и от финансового состояния организации.

Риск - потенциальная, численно измеримая возможность неблагоприятных ситуаций и связанных с ними последствий в виде потерь, ущерба, убытков, вплоть до банкротства и ликвидации предпринимательской единицы в связи с нестабильностью и неопределенностью, то есть с отдельных элементов предпринимательской среды, неблагоприятными обстоятельствами экономической деятельности, получения непредсказуемого результата в зависимости от принятого хозяйственного решения, действия.

Таким образом, предпринимательская деятельность проходит в условиях нестабильности, неопределенности и рисков и эти категории взаимосвязаны.

В количественном отношении нестабильность и неопределенность подразумевают возможность отклонения результата от ожидаемого (или среднего) значения, как в меньшую, так и в большую сторону. Соответственно, под риском в данном контексте понимается вероятность потери части своих ресурсов, недополучения доходов или появления дополнительных расходов и (или) обратное - невозможность получения значительной выгоды (дохода) в результате осуществления определенной целенаправленной деятельности. Поэтому эти три категории, влияющие на предпринимательскую деятельность и реализацию предпринимательской идеи, должны анализироваться и оцениваться совместно.

Предпринимательский риск имеет объективную основу из-за нестабильности внешней среды и неопределенности ее воздействия по отношению к предпринимателю.

С экономической точки зрения предпринимательский риск представляет собой событие, которое может произойти с некоторой вероятностью, при этом возможно три экономических результата (оцениваемых в экономических, чаще всего финансовых показателях): отрицательный, т. е. ущерб, убыток, проигрыш; положительный, т. е. выгода, прибыль, выигрыш; нулевой (ни ущерба, ни выгоды).

Природа нестабильности, неопределенности, рисков и потерь (рис. 1.5) при осуществлении предпринимательской деятельности связана с финансовыми убытками предпринимателя. 


\begin{tabular}{|c|c|}
\hline Нестабильность & Неопределенность \\
\hline $\begin{array}{l}\text { Непривычное } \\
\text { поведение или изменение } \\
\text { отдельных элементов пред- } \\
\text { принимательской среды. }\end{array}$ & $\begin{array}{c}\text { Неполнота или неточность } \\
\text { информации об условиях } \\
\text { реализации } \\
\text { предпринимательской идеи }\end{array}$ \\
\hline
\end{tabular}

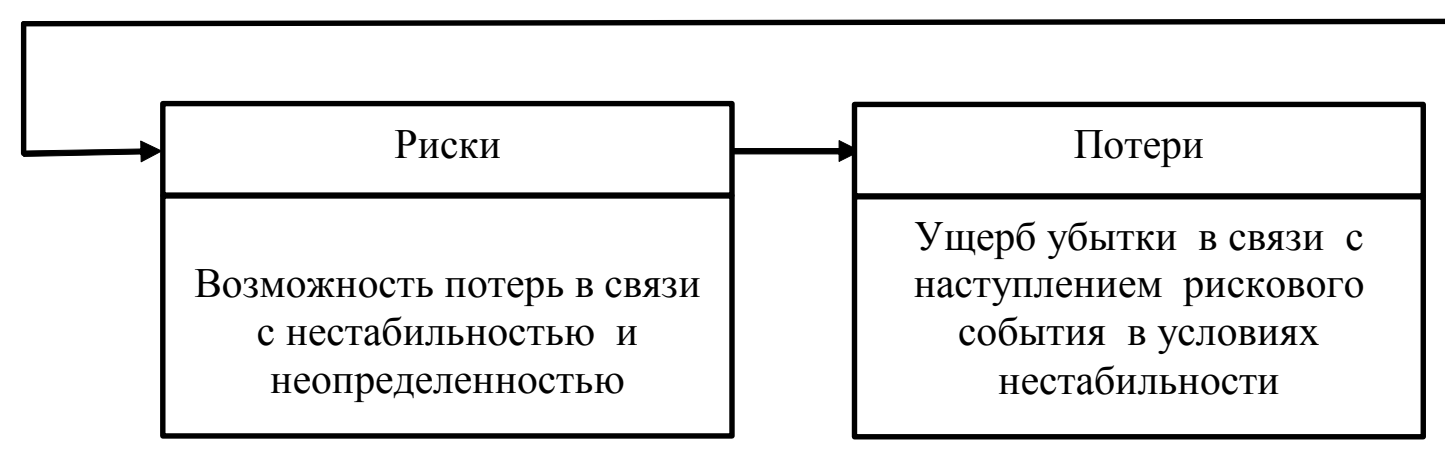

Рис. 1.5. Взаимосвязь категорий:

нестабильность - неопределенность - риски - потери

Финансовые риски можно объединить в три главные категории: риск локальный (чистый), спекулятивный и глобальный (рис. 1.6).

Локальный (чистый) риск, когда результатом их являются потери, но нет возможности вычгрыша.

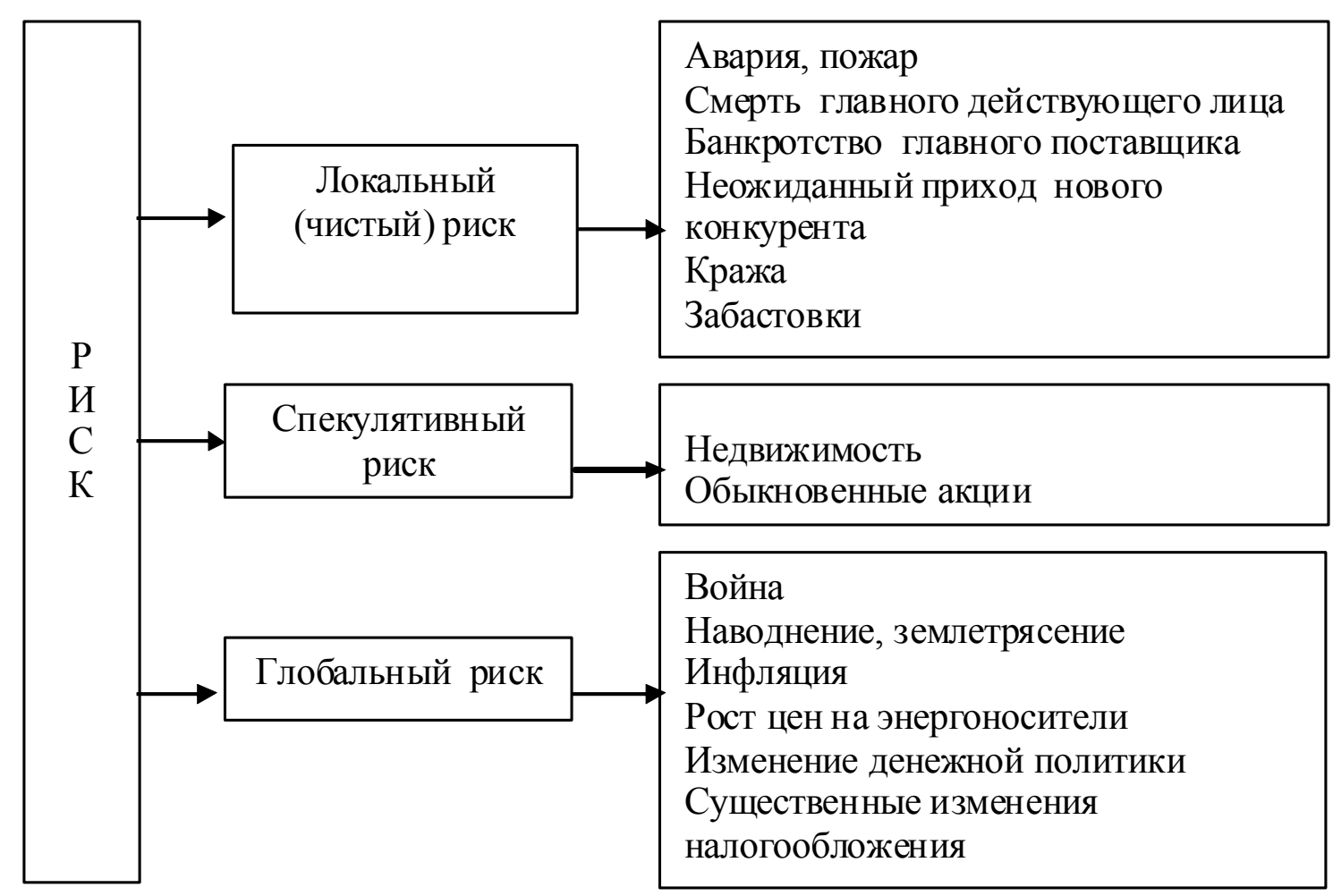

Рис. 1.6. Категории финансового риска 
Локальные риски возникают на уровне предпринимательской единицы Предприниматель мало, что может сделать для того, чтобы избежать локального (чистого) риска. Так любой предприниматель, имеющий грузовик должен считаться с риском аварии, а если он имеет объект недвижимости - с риском пожара.

Спекулятивный риск. При локальном (чистом) риске предприниматель может терпеть убытки или остаться без прибыли. В случае же спекулятивного риска предприниматель или вылгрывает, или проигрывает. Например, предприниматель решает вложить капитал в земельный участок в надежде на то, что земля поднимется в цене, но в зоне влияния начато строительство экологически вредного объекта (алюминиевый завод), стоимость земельного участка понижается.

Подобные инвестиции можно квалифицировать как спекулятивные, так как именно предприниматель, а не слепой случай подвергает его риску потерь. Точно так же инвестиции на приобретение обыкновенных акций могут принести или прибыль, или убыток.

Глобальный риск отличается как от чистого, так и от спекулятивного риска своим безличностным характером. Иными словами, глобальный риск не имеет фаворитов. Судьба не выделяет какого-то предпринимателя и обходит своим вниманием все остальные. Напротив, глобальный риск в одинаковой мере затрагивает всех участников предпринимательской деятельности. Как правило, он связан с экономическими, политическими, социальными и природными силами, воздействию которых подвержено человеческое общество.

Риски по своей природе весьма многочисленны и разнообразны, поэтому существует множество классификаций. Одна из них приведена в прил. 2.

Может показаться вполне очевидным тот факт, что предприниматели осознают существование всевозможных рисков, особенно таких, которые оказывают влияние на непосредственно их предпринимательскую деятельность. И тем не менее предприниматели часто игнорируют риск, особенно риск такого рода, который не кажется столь очевидным, поэтому предпиниматели просто обязаны подвергать всестороннему анализу все мыслимые возможности потерь.

Только с помощью такого анализа предприниматель может оградить свою деятельность от потерь, связанных с локальным (чистым) риском. Хотя эту цель оградить себя от возможных потерь - нетрудно осознать и поставить перед собой, достичь ее довольно трудно. Главной причиной этого является то обстоятельство, что управление предпринимательской деятельности с учетом риска относится к области скорее искусства, чем науки, и во многих случаях с трудом поддается точному анализу.

Так как риск - постоянный спутник предпринимательской деятельности -это заставляет предпринимателя не только анализировать варианты возможных альтернатив, но и искать возможность снизить его. Методы снижения рисков приведены на рис. 1.7. Рассмотрим их. 


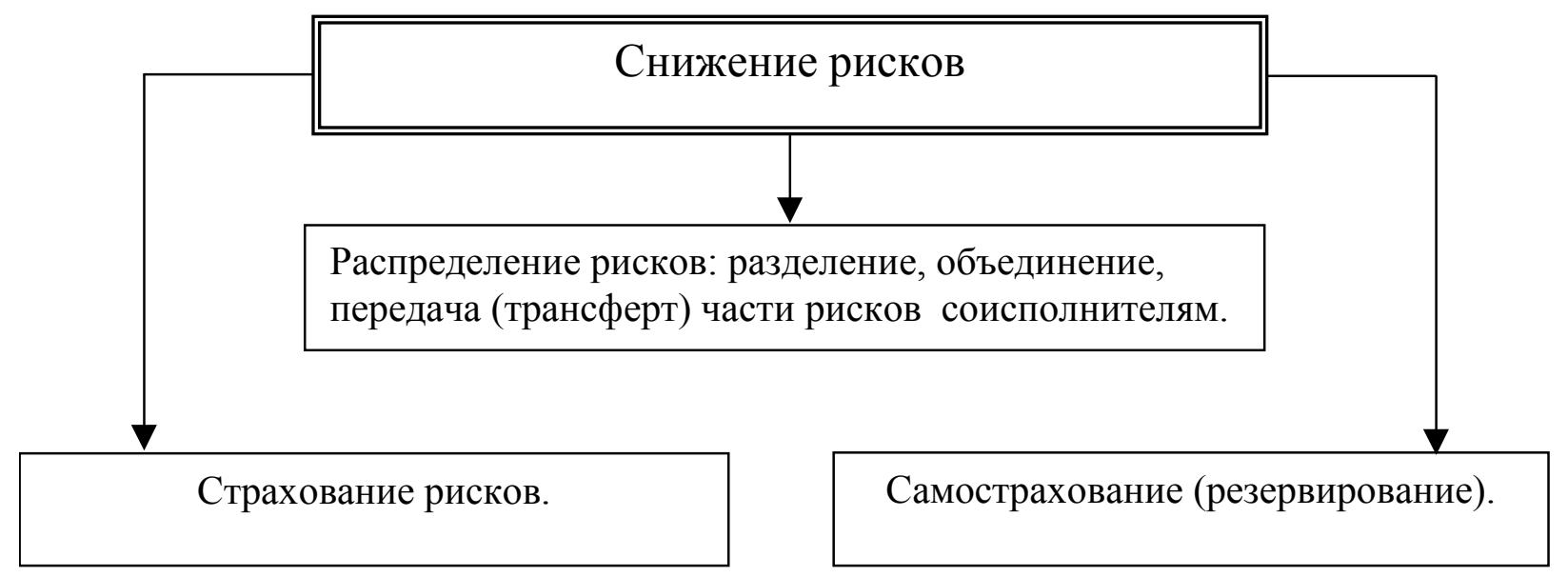

Рис. 1.7. Методы снижения рисков

Суть метода разделения рисков заключается в сокращении максимально возможных потерь за одно событие путем разделения активов фирмы, при одновременном возрастании числа рисков, за которыми необходимо следить.

Активы можно разделить следующим образом:

физически, т.е. хранить свободные денежные средства в различных банках;

по собственности, например, собственность фирмы записывается на имя управляющих компанией, созданных для этих целей.

Под объединением риска понимается метод снижения рисков, при котором возможный риск делится между несколькими субъектами экономики, что делает потери более предсказуемыми. В данном случае возрастает число единиц, подверженных риску, находящихся под контролем предпринимателя. Например, горизонтальная или вертикальная интеграция фирм с целью расширения рынка и т.Д.

Самым распространенным методом снижения риска является полная или частичная передача (трансферт) $)^{1}$ риска другой стороне, что позволяет учесть интересы сторон, участвующих в предпринимательской деятельности.

Как правило, вторая сторона:

лучше умеет просчитывать риски, знает лучшие способы и имеет больше возможностей для сокращения возможных потерь;

лучше умеет контролировать возможные риски и находится в преимущественной, по отношению к передающей стороне, позиции для сокращения возможных потерь, связанных с возникновением рисковой ситуации;

потери, в случае их возникновения, для второй стороны являются незначительными, в тоже время для предпринимательства они настолько существенны, что могут привести к потере финансовой самостоятельности и банкротству предпринимательской организации.

Основной способ передачи риска это заключение контрактов, возможные типы

\footnotetext{
${ }^{1}$ От фр. transfert - переводить.
} 
Возможные типы контрактов по передачи рисков

\begin{tabular}{|c|c|}
\hline Типы контрактов & Особенности \\
\hline 1 & 2 \\
\hline 1. Строительные контракты \\
\hline
\end{tabular}

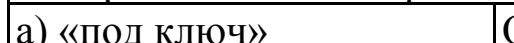

Ответственность возлагается на подрядчика до момента полной передачи объекта заказчику. Сюда входят: технологическое оборудование, материалы, запчасти и др., отдельно может быть включена частичная или полная ответственность подрядчика за порчу строительных механизмов. Оговариваются штрафные санкции за несвоевременную сдачу объекта в эксплуатацию и т.д.

б) «поставка оборудова-

Мерой ответственности подрядчика являются только последствия ния и контроль за строи- его действий и упущений по этим двум видам деятельности, без тельством»

учета стоимости оборудования, материалов и т.П., являющихся собственностью заказчика.

2. Аренда

(финансовый лизинг)

Часть рисков, связанных с арендованным имуществом, лежит на собственнике (арендодателе) - риск физических повреждений собственности; риск снижения коммерческой ценности объекта и т.п. К арендатору полностью переходит риск случайной гибели и риск случайной порчи арендованного имущества в момент передачи ему этого имущества.

3.Контракты на хранение и перевозку грузов

Объем передаваемых рисков зависит от статуса сторон, заключающих договор, и условий, оговоренных в договоре. Транспортной компании передаются, как правило, статические риски, связанные с гибелью товара во время перевозки. Динамические риски несет предпринимательская организация

4. Контракты продажи, обслуживания, снабжения.

a) гарантийные обяза- $\quad$ Предприятие-изготовитель берет на себя обязанность по устранетельства течение конкретного, заранее оговоренного договором промежутка б) соглашения о снабжении товаром на условиях поддержания неснижаемого остатка на складе

в) договора на сервисное обслуживание техники

5. Контракт-поручитель- Фигурируют три стороны; поручитель - принципал - кредитор. Поство времени

ручитель (юридическое или физическое лицо) принимает на себя риск неудачи деятельности принципала и дает гарантии кредитору на возмещение кредита в любом случае. 


\begin{tabular}{|c|c|}
\hline $\begin{array}{l}\text { 6. Договор факторинга } \\
\text { (финансирование под } \\
\text { уступку денежного тре- } \\
\text { бования) }\end{array}$ & $\begin{array}{l}\text { Передача кредитного риска. Участвуют три стороны: фактор- } \\
\text { посредник - предприятие - поставщик - предприятие -покупатель. } \\
\text { Фактор-посредник приобретает дебиторскую задолженность и в те- } \\
\text { чение двух-трех дней оплачивает } 70-80 \text { \% требований в виде аванса, } \\
\text { оставшаяся часть погашается по мере поступления средств на его } \\
\text { счета. }\end{array}$ \\
\hline 7. Биржевые сделки & $\begin{array}{l}\text { Снижение риска снабжения в условиях инфляционных ожиданий и } \\
\text { отсутствия надежных каналов закупки. }\end{array}$ \\
\hline $\begin{array}{l}\text { a) опционы на закупку } \\
\text { товаров и услуг }\end{array}$ & $\begin{array}{l}\text { Поставщик гарантирует продажу товара по фиксированной цене в } \\
\text { течение определенного срока. Опционы имеют вторичное хождение } \\
\text { на рынке, т.е. могут быть проданы по текущей котировке. }\end{array}$ \\
\hline $\begin{array}{l}\text { б) фьючерсные контрак- } \\
\text { ты на закупку растущих в } \\
\text { цене товаров }\end{array}$ & $\begin{array}{l}\text { 1. Исполнение контракта после его подписания отложено на опре- } \\
\text { деленный срок. } \\
\text { 2. Момент времени, в который совершается поставка товара или } \\
\text { услуги, строго фиксирован. } \\
\text { 3. В контракте может быть предусмотрена «плавающая» цена по- } \\
\text { ставки. Таким образом, покупатель получает гарантию получения } \\
\text { товара (услуги) в нужный срок по оговоренной цене, снижая тем } \\
\text { самым риск снабжения и инфляционный риск. С другой стороны } \\
\text { есть возможность отказа от контракта, если будут найдены альтер- } \\
\text { нативные и более эффективные каналы снабжения. }\end{array}$ \\
\hline
\end{tabular}

При передаче риска необходимо учитывать:

распределение риска между сторонами должно носить четкий характер;

принимающая сторона должна иметь возможности своевременного выполнения всех взятых на себя обязательств;

решение о передаче риска должно приниматься на базе критерия эффективности, в сравнении с аналогичными по надежности, методами снижения риска;

риск должен передаваться по обоюдно выгодной цене.

Страхование рисков как метод минимизации представляет собой сделку о передаче локального (чистого) риска путем заключения двустороннего договора. Страхование рисков представляет собой отношения по защите имущественных интересов предпринимателя при наступлении определенных событий (страхование случаев) за счет денежных фондов, формируемых из уплачиваемых ими страховых взносов (страховых премий).

Взамен на определенное вознаграждение, называемое премией, страховая компания соглашается выплатить обусловленную сумму для покрытия убытков при обстоятельствах, указанных в тексте договора, который называется страховой полис. Приобретая такой документ, предприниматель обменивает неопределенность крупной потери, - скажем, уничтожения здания стоимостью 5 млн. р. от пожара - на определенность малой потери - страховой премии.

Страховые компании считают, что риск может быть застрахован, если он отвечает следующим четырем критериям:

риск связан с угрозой большому числу клиентов;

убытки должны быть делом случая и не должны быть подвластны воле пред- 
принимателя;

убытки должны поддаваться точному измерению;

вероятные убытки должны быть столь серьезными, что предприниматель не сможет их восполнить.

В отечественной предпринимательской практике наблюдается активизация страхования профессиональной ответственности. Так, например, в сфере недвижимости популярно страхование:

профессиональной ответственности: риэлтеров, оценщиков, водителей и т.д.;

строительно-монтажных рисков;

банковских ипотечных кредитов под покупку уже построенного жилья;

инвесторов-дольщиков.

Страхование профессиональной ответственности получило развитие и при осуществлении предпринимательской деятельности по антикризисному управлению.

В законодательстве РФ введено понятие предпринимательского риска. Страхование предпринимательского риска предполагает заключение договора имущественного страхования, по которому одна сторона (страховщик) обязуется за обусловленную договором плату (страховую премию) при наступлении предусмотренного в договоре события (страхового случая) возместить другой стороне (страхователю) или иному лицу, в пользу которого заключен договор (выгодоприобретателю), причиненные вследствие этого события убытки в застрахованном имуществе либо убытки в связи с иными имущественными интересами страхователя (выплатить страховое возмещение) в пределах определенной договором суммы (страховой суммы).

По договору имущественного страхования могут быть, в частности, застрахованы следующие имущественные интересы:

риск утраты (гибели), недостачи или повреждения определенного имущества;

риск ответственности по обязательствам, возникающим вследствие причинения вреда жизни, здоровью или имуществу других лиц, а в случаях, предусмотренных законом, также ответственности по договорам - риск гражданской ответственности;

риск убытков от предпринимательской деятельности из-за нарушения своих обязательств контрагентами предпринимателя или изменения условий этой деятельности по не зависящим от предпринимателя обстоятельствам, в том числе риск неполучения ожидаемых доходов - предпринимательский риск.

Одним из видов имущественного страхования является страхование предпринимательского риска, когда может быть застрахован предпринимательский риск только самого страхователя и только в его пользу. Договор страхования предпринимательского риска лица, не являющегося страхователем, ничтожен. Договор страхования предпринимательского риска в пользу лица, не являющегося страхователем, считается заключенным в пользу страхователя.

При заключении договора страхования предпринимательского риска страховщик вправе произвести анализ рисков, а при необходимости назначить экспертизу. Оценка страхового риска страховщиком необязательна для страхователя, который вправе доказывать иное. 
При страховании предпринимательского риска, если договором страхования не предусмотрено иное, страховая сумма не должна превышать их действительную стоимость (страховой стоимости). Такой стоимостью для предпринимательского риска считаются убытки от предпринимательской деятельности, которые страхователь, как можно ожидать, понес бы при наступлении страхового случая.

Если в договоре страхования предпринимательского риска страховая сумма установлена ниже страховой стоимости, страховщик при наступлении страхового случая обязан возместить страхователю часть понесенных последним убытков пропорционально отношению страховой суммы к страховой стоимости'.

Самострахование (резервирование) - создание предпринимателем специального резервного фонда за счет отчислений из прибыли на покрытие непредвиденных расходов наступлении рисковых событий

Данный способ предусматривает установление соотношения между потенциальными рисками, влияющими на стоимость того или иного проекта, и размером расходов, необходимых для преодоления сбоев в выполнении проекта. Основной проблемой при создании резерва на покрытие непредвиденных расходов является оценка потенциальных последствий иска.

В настоящее время существуют различные методики формирования резервных (страховых) фондов. Все они, как правило, исходят из средневзвешенной величины различных компонентов: ресурсов, текущих активов, основного капитала.

За рубежом достаточно распространенной практикой является формирование величины страхового фонда в размере:

$1 \%$ от стоимости активов;

$1-5 \%$ от стоимости продаж;

3-5 \% от годового фонда выплат акционерам и т.п.

Одним из способов определения величины средств, направляемых на создание резервного фонда, может быть следующий: среднюю сумму потерь прошедшие три года необходимо разделить на среднегодовые, суммы, скорректировав их на среднегодовые темпы инфляции.

Самострахование - это слишком дорогостоящее дело для большинства предпринимателей. Лишь немногие могут уменьшить риск с помощью избыточных финансовых ресурсов и специально образованного страхового резервного фонда, т.к. он не вовлекается в оборот и является «мертвым», неработающим капиталом, не приносящим прибыли.

Самострахование целесообразно в том случае, когда стоимость страхуемого имущества, по сравнению с имущественными и финансовыми критериями всего бизнеса, невелика, а также, когда вероятность убытков чрезвычайно мала.

Предупреждение потерь также практикуется предпринимателями, хотя и не в такой степени, как методы снижения риска. Для того чтобы свести к минимуму вероятность риска, предприниматели могут:

проектировать свое производство, офис, магазин или склад таким образом, чтобы минимизировать вероятность пожара и несчастных случаев с работниками:

${ }^{1}$ Мазур И.И., Шапиро В.Д. и др. Управление проектами.-М.: Высшая школа, 2001.-875 с. 
проводить обучение работников технике безопасности и охране труда; содержать в исправном состоянии пожарно-охранную сигнализацию; охранять имущество, нанимая для этого специалистов, улучшая охранную сигнализацию и тщательно проверяя всех вновь поступающих на работу.

Подобные практические мероприятия могут предотвратить или хотя бы уменьшить потери.

Вероятность рисков - это вероятность того, что в результате принятия решения произойдут потери для предпринимателя. Вероятность при этом означает возможность получения определенного результата. Существует два метода определения вероятности нежелательных событий: объективный и субъективный. Объективный метод основан на вычислении частоты, с которой тот или иной результат обычно получен в аналогичных условиях. Субъективная вероятность является предположением относительно определенного результата. Этот метод определения вероятности нежелательного исхода основан на суждении, личном опыте и информированности предпринимателя.

Различные методы борьбы с возможными убытками базируются на работе с информацией. Недостоверность информации о партнерах (заказчиках, поставщиках и др.) особенно об их деловом имидже и финансовом состоянии грозит предпринимателю риском быть обманутым («кинутым»). Неполная информация о конкурентах при выходе на новый рынок также может стать источником потерь для предпринимателя. Таким образом, успех применения тех или иных методов зависит от степени достоверности и полноты информации.

Информация состоит из всех объективных факторов и предположений, влияющих на восприятие предпринимателем, принимающим решение, сущности и степени неопределенности, связанной с риском. Следовательно, все, что потенциально позволит снизить степень неопределенности, будь то факты, оценки или прогнозы, должно считаться информацией, которая может быть получена с использованием первичных и вторичных данных.

Первичные данные получают в результате исследований, специально проведенных для решения конкретной проблемы. Сбор данных в этом случае осуществляется путем наблюдений, изменений, опросов, интервью, экспериментов.

Количественные исследования связаны с проведением измерений и различных опросов. Характерными особенностями таких исследований являются: четко определенные формы данных и источники их получения, обработка собранных данных с помощью упорядоченных количественных процедур

Качественные исследования включают сбор, анализ и интерпретацию данных путем наблюдений, осуществляемых в нестандартной форме. Качество информации во многом определяется объемом выборки, для определения которой могут использоваться вероятностный метод и метод экспертной оценки.

Bторичные данные - это данные, собранные ранее из внутренних и внешних источников для целей, отличных от целей данного исследования. Вторичные данные являются наиболее доступным и дешевым способом получения информации о возможных рисках, которые можно почерпнуть из различных источников, как внешних, так и внутренних (рис. 1.8).. 
Как правило, сбор вторичной информации предшествует сбору первичной и повышает ее эффективность.

Основными недостатками вторичной информации является возможная несогласованность единиц измерения, использование различных определений и систем классификаций, трудность оценки достоверности. Использование такой информации возможно только в том случае, если удается преобразовать всю полученную информацию таким образом, чтобы она удовлетворяла предъявленным к ней требованиям.

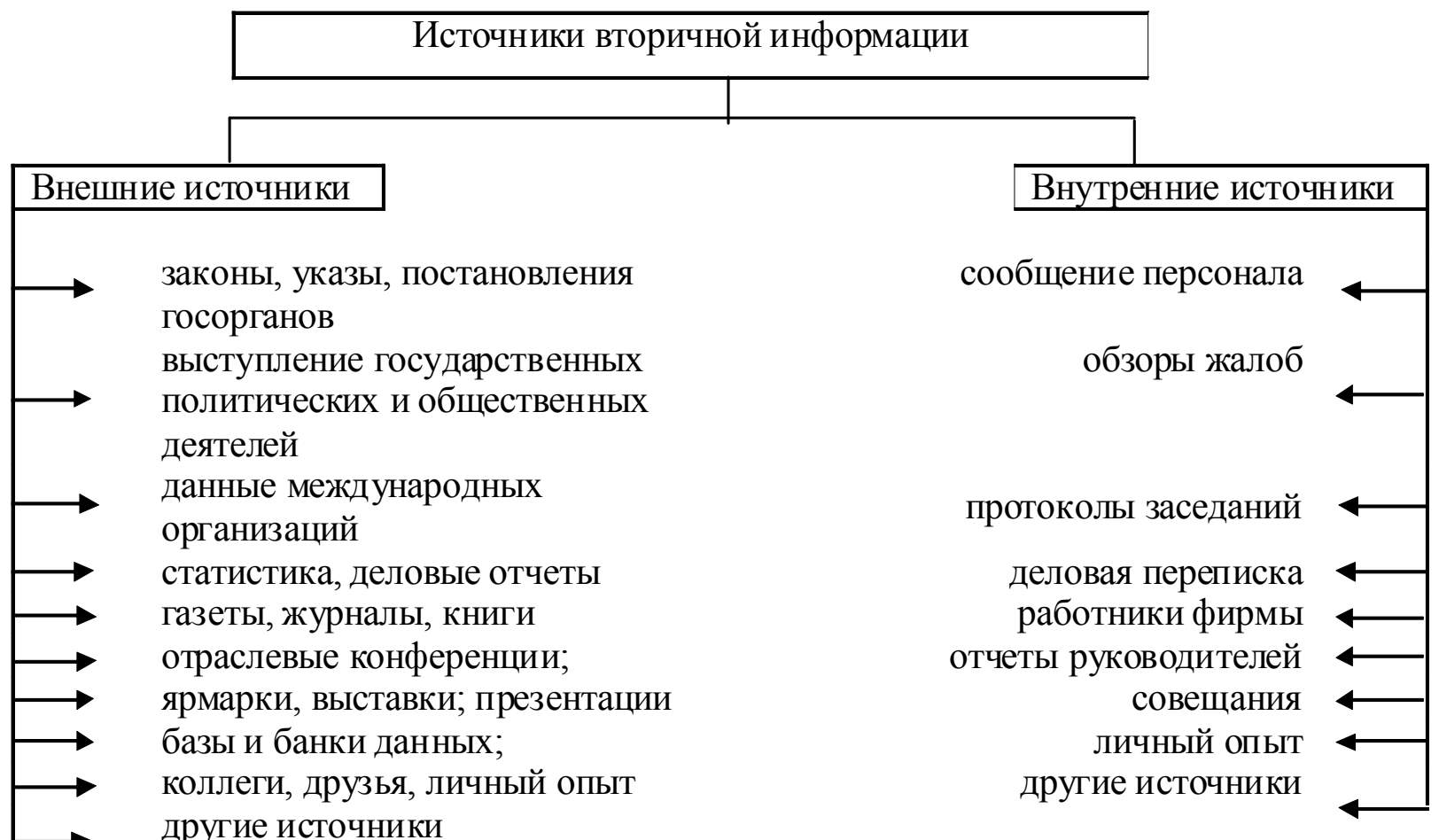

Рис. 1.8. Классификация источников вторичной информации

Разнообразие источников получения вторичной информации, и ее значительные объемы выдвигают необходимость тщательного анализа документов, содержащих информацию. На практике используются два основных типа анализа: традиционный (классический) и формализованный (количественный).

Традииионный анализ - цепь логистических построений, направленных на выявление сути анализируемого метода. Основной недостаток - субъективизм.

Формализованный анализ позволяет избавиться от субъективности за счет применения количественных методов. Однако, вследствие того, что не вся информация в документах может быть измерена количественно, данный метод носит ограниченный характер.

Внешнюю информацию можно подразделить на официально опубликованную и синдикативную (информацию, которую специальные информационноконсульские организации собирают, обрабатывают и продают своим подписчи- 
кам).

Техника формирования базы данных о критических точках среды, достижение которых может привести систему в состояние неустойчивости, включает в себя:

сканирование среды - изучение потока информации существующей в ретроспективе (позволяет выявить аналогичные риски и оценить их последствия для системы);

мониторинг среды - отслеживание текущей и вновь появляющейся информации с целью недопущения возникновения критической ситуации и потери устойчивости системы;

прогнозирование - создание информации о будущем среды, ее прогнозных критически точках (точках риска),

Методы сбора первичной информации делятся на количественные и качественные.

Оценивая информацию, необходимую для принятия надежного решения, следует учитывать ее своевременность, труднодоступность и, зачастую, слишком высокую стоимость. Перед предпринимателем всегда стоит вопрос определения оптимального объема информации в зависимости от затрат на нее и времени, потраченного на сбор.

Оценивая риски, которые предприниматель в состоянии принять, он, прежде всего, исходит из специфики предпринимательской идеи и важности проекта, из наличия необходимых ресурсов для ее реализации и возможностей финансирования вероятных последствий рисков. Степень допустимых рисков определяется с учетом таких параметров, как размер и надежность инвестиций в предпринимательский проект, запланированного уровня рентабельности и др.

Измерение рисков - определение вероятности наступления рискового события.

Для предпринимателя работа по идентификации рисков никогда не заканчивается, ибо по мере развития предпринимательского проекта появляются новые риски. Так выпуск нового изделия может быть связан с подверженностью новому риску. Задача предпринимателя и состоит в выявлении этих рисков и определения подверженности потерям от риска (см. рис. 1.9)

Таким образом, предпринимательский риск - экономическая категория, количественно и качественно выражающцаяся в неопределенности исхода намеченной к осуществлению предпринимательской идеи, отражающей степень успеха предпринимателя.

Предпринимательская деятельность предполагает не только констатацию факта наличия нестабильности, неопределенности, но и анализ рисков, управление рисками. 


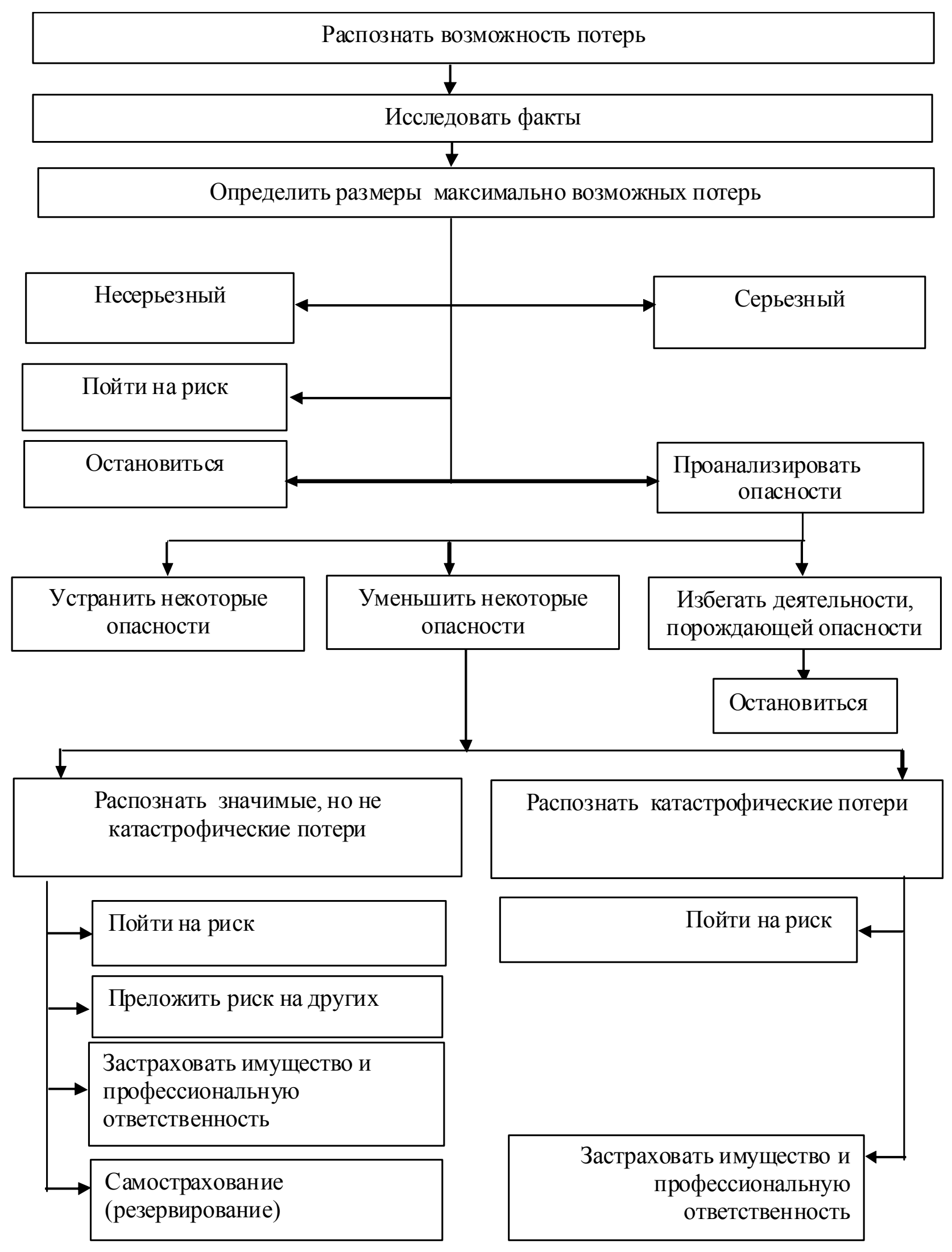

Рис. 1.9. Схема определения подверженности потерям от риска

Предприниматели должны защищать себя и свои организации от непредвиденного развития событий, которые могут парализовать предпринимательскую 
деятельность и привести к краху.

Есть четыре способа управления рисками: избегать риска; справиться с риском самому; предотвратить наступление неблагоприятного события; переложить риск на других.

Для того чтобы остановить свой выбор на одном из названных практических подходов, предпринимателю следует предварительно проанализировать степень своей подверженности риску, прибегая при этом к консультанту. Программа управления риском, которая станет результатом такого анализа, должна:

- четко выявить риски, которые могут привести к финансовым потерям;

- дать оценку того, насколько серьезными могут быть потери;

- выбрать оптимальный способ преодоления этих рисков.

Присутствие риска в предпринимательской деятельности имеет то общеэкономическое значение, что, с одной стороны, заставляя предпринимателя скрупулезно анализировать варианты возможных альтернатив, выбирая лучшие и наиболее перспективные из них, оборачивается прогрессивными сдвигам в производительных силах и ростом эффективности производства, а с другой - указывает на необходимость применения в отношении предпринимательской деятельности определенных ограничений и регламентации. 


\section{ГЛАВА 2 ПРЕДПРИНИМАТЕЛЬСКАЯ СРЕДА}

\section{1 Внешняя и внутренняя среда предпринимательства}

Под предпринимательской средой (ПС) понимается наличие условий и факторов, воздействующих на предпринимательскую деятельность и требующих принятия управленческих решений для их устранения или приспособления.

ПС представляет собой интегрированную совокупность объективных и субъективных факторов, позволяющих предпринимателям добиваться успеха в реализации поставленных целей и подразделяется на внешнюю, как правило, не зависимую от самих предпринимателей, и внутреннюю, которая формируется непосредственно самими предпринимателями.

Внешняя среда предпринимательства представляется сложным гетерогенным $^{1}$ образованием, охватывающим широкий круг элементов, взаимосвязанных как с фирмой - субъектом предпринимательской деятельности, так и между собой, образующие своеобразное системно - организованное «пространство», в котором функционируют и развиваются процессы, ограничивающие или активизирующие предпринимательскую деятельность. Чтобы раскрыть структуру внешней среды предпринимательства следует обратиться к характеру взаимоотношений, складывающимися между субъектом предпринимательства и средовыми элементами. В этом случае можно выделить ряд элементов, которые не подвержены непосредственному управляющему воздействию со стороны фирмы и не могут адекватно реагировать на ее поведение в силу косвенного, не опосредованного воздействия. Например, предприниматель не в состоянии оказать прямое влияние на характер деятельности фирм - конкурентов, однако формируя качество производимых товаров, реализуя определенную ценовую политику, проводя мероприятия, способствующие укреплению своего имиджа и общественного признания, оно создает определенные условия конкуренции, учитываемые всеми организациями, конкурирующими на рынке. Предпринимательская система, таким образом, оказывает ощутимое влияние на всех участников процесса конкуренции, распространяемое косвенным путем с помощью инструментов маркетингового воздействия. Такое влияние улавливается рынком и требует адекватного реагирования со стороны его различных субъектов.

Элементы внешней среды, поддающиеся косвенному воздействию со стороны системы предпринимательства, могут быть объединены в устойчивую и достаточно однородную совокупность с помощью критерия, выражающего характер воздействия (опосредованное). Эта совокупность может характеризоваться как отдельная группа элементов внешней среды - микроокружающая среда.

Изучая микроокружающую среду, важно помнить, что она не только испытывает некоторое влияние со стороны конкретной предпринимательской органи-

\footnotetext{
${ }^{1}$ От гр. heterogenes - неоднородный по составу.
} 
зации и адекватно реагирует на его поведение на рынке, но и оказывает заметное формирующее влияние на стиль и характер предпринимательской деятельности. Микроокружающая среда как - бы находится в фокусе рыночных процессов, отражающем наиболее существенные рыночные колебания. Ее элементы пребывают в состоянии постоянного взаимовлияния, когда каждый из них способен обуславливать изменения в поведении другого, но и вынужден приспосабливаться к этим изменениям.

Вместе с элементами микроокружающей среды во внешней среде предпринимательства отражается влияние факторов, имеющих более “жесткий” характер. Эти факторы (их можно назвать факторами макроокружающей среды) носят ограничивающие, а иногда и стимулирующие свойства, но в любом случае, свойства, проявляющиеся в одном направлении от элемента среды к конкретной предпринимательской организации.

Важнейшей особенностью таких факторов является отсутствие возможности для какого-либо воздействия на них со стороны отдельных субъектов рынка, и наоборот - необходимость в приспособлении к формируемым ими условиям. Безусловно, в общетеоретическом плане, вряд ли правомерно говорить о полном отсутствии возможности для воздействия на какие-либо факторы, так как все элементы социально-эколого-экономических систем находятся в единстве и динамической взаимосвязи. Можно говорить лишь об очень незначительном воздействии, практически не имеющем проявления в практике предпринимательства, и которым можно пренебречь при решении конкретных управленческих задач. Так, например, нельзя не отметить влияние предпринимательства, как явления, и предпринимателей, как его представителей, на характер правовой и нормативной базы. Предприниматель высказывает предпочтение той или иной форме государственного устройства, обладающей нормативно - правовыми рычагами, участвует в создании определенного общественного мнения, наконец, отдает свой «голос» представителям той или иной политической платформы, но вряд ли можно утверждать, что его позиции и действия могут иметь существенное, формирующее значение. Более целесообразен и плодотворен прогноз и учет государственнорегулируемых правовых процессов, чем попытки их приспособления к собственным интересам. Факторы макроосреды, таким образом, образуют некий ограничительный сегмент, требующий изучения со стороны предпринимательских структур и активного приспособления.

Макроокружающзая внешняя среда включает широкую совокупность элементов: природных, демографических, экономических, экологических, научно - технологических, законодательных, национальных и т.д. Они имеют различный характер и социально - экономическую природу и оказывают различное воздействие на тот или иной вид производственной и предпринимательской деятельности.

Чтобы выделить факторы, обуславливающие параметры конкретного предпринимателя, необходимо располагать научно обоснованной классификацией, отражающей структуру макрофакторов. В основу такой классификации могут быть положены пять крупных групп элементов, отражающих различные стороны социально - экономических взаимоотношений (рис. 2.1).

Каждый из этих элементов обладает собственной многокомпонентной струк- 
турой. Группа, объединяющая научно - технические элементь отражает уровень научно - технического развития, накладывающий технические и технологические ограничения на конкретный вид предпринимательства. Так, в условиях российского рынка заметно ограничивающее влияние уровня развития информационных технологий, охватывающее практически все области предпринимательской деятельности.

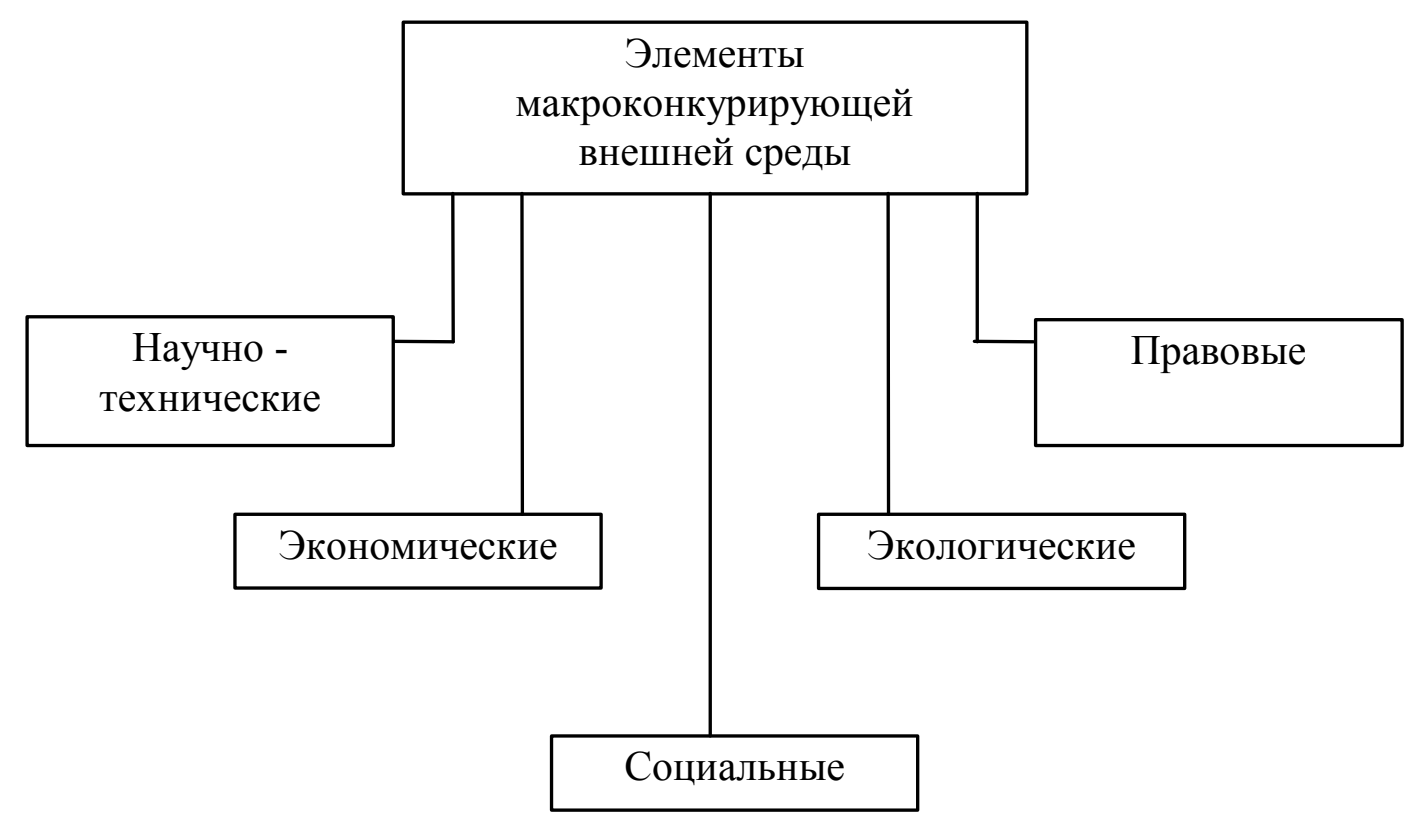

Рис. 2.1. Структура элементов макроокружающей внешней среды

Экономические элементы обуславливают, в первую очередь, объем денежных средств, которые потребитель может направить на рынок конкретного товара и которые формируют условия спроса и емкость данного рынка. Действие этих элементов определяет и структуру спроса, включающую различные виды товаров, соответствующих потребительским предпочтениям и доступных по цене.

Экономические факторы макросреды охватывают и сформировавшийся рынок труда, наличие свободных рабочих мест и, следовательно, избыток или недостаток рабочей силы, что влияет на уровень заработной платы работников.

К числу экономических факторов можно отнести особенности развития производственной сферы. При этом важно рассматривать два аспекта развития производственного базиса: отраслевой и региональный. В отраслевом аспекте изучается производственная, технологическая и организационная иерархия отраслевой структуры, ее ретроспективная динамика и перспективы. В региональном - требуется изучение характера размещения производительных сил и конкретных объектов производственной инфраструктуры, определяющих структуру предложения в границах конкретного региона, особенности материально - технической базы производственных процессов, оказывающих влияние на показатели эффективности производственной и всей предпринимательской деятельности. Учитывая особенности российского рынка, важно выделить в качестве особого структурного элемента производственно - транспортную инфраструктуру, ее мощность, протя- 
женность, техническую оснащенность, а также действующие тарифы на перевозки.

Экономическая ситуация формируется под влиянием политических факторов. Способы управления экономикой и обуславливаемая ими экономическая обстановка являются, в какой - то мере, отражением политических целей и задач, решаемых правительственными органами. Политические факторы иногда рассматривают как самостоятельные средоборазующие факторы, однако их влияние на условия конкретного бизнеса проявляются обычно посредством других факторов, в частности - экономических, накладывающих четко очерченные ограничительные рамки на многие параметры предпринимательской деятельности.

Политическая ситуация оказывает влияние на другие факторы внешней среды: социальные, правовые, экологические. Наибольший «политический импульс» испытывает на себе правовая среда. Виды законов и других правовых актов являются, как правило, следствием политических процессов, лоббирования и общественно-политическим давлением. Правовые документы любого вида всегда являются «жесткими» и однозначными ограничителями предпринимательства.

Политические факторы оказывают влияние на экологическую ситуацию, в частности - в виде протекционизма по отношению к общественным движениям в области борьбы за сохранение и восстановление окружающей среды. Таким образом, политические факторы распространяют свое влияние, минуя несколько ступеней - с помощью экономических, правовых или иных характеристик. При этом можно допустить их отсутствие в представленной структуре элементов, где выделены те, что находятся в непосредственном контакте с предпринимательским звеном и реально формирующем границы ее деятельности.

Расширенную совокупность элементов объединяют экологические факторы. Выражающие взаимоотношения между обществом и природой, они включают три самостоятельные подгруппы элементов:

природно-климатические;

природно-ресурсные;

природо-охранные.

Природно-климатические факторы выражают особенности географического местоположения потребительского рынка и удовлетворяющие его спрос предпринимательской структуры. Важно отметить, что требуют учета оба вида таких факторов, так как природные условия, в которых функционирует потребитель и предприниматель могут не совпадать.

Природно-ресурсные факторы связаны с наличием, объемом, качеством и условиями использования всех видов природных ресурсов, используемых в предпринимательской деятельности. В их числе: природное сырье, запасы воды, топлива, энергии.

Природо-охранные компоненты выражают степень загрязнения экосистемы, окружающей территорию потребительского рынка, включающей все ее компоненты. Влияние природо-охранных факторов выражается как в фиксированной степени экологического загрязнения, так и в форме, обуславливающей тип общественного поведения в отношении экологических проблем.

С точки зрения современной социально - этической потребности наиболее 
пристального внимания заслуживают социальные элементы макроокружающей внешней среды. Их группа, пожалуй, наиболее многочисленна. Пытаясь дать расширенную характеристику ее структуре, экономической природе и характеру воздействия на предпринимательскую деятельность, можно выделить две подгруппы:

элементы, имеющие материально-вещественную форму выражения;

элементы, не имеющие такой формы.

В первой подгруппе представлены конкретные объекты социальной инфраструктуры конкретного рынка. К числу таких объектов можно отнести широкую совокупность систем и сетей, обеспечивающих жизнедеятельность индивидуума, их групп и общества в целом. Это - объекты инженерного обеспечения, культурно - бытовой сферы, общественного транспорта, охраны общественного порядка, регионального и местного управления. Их наличие и отсутствие формируют условия для определения способа ведения предпринимательской деятельности, ее масштабов и территориальной специфики. Так, например, при отсутствии широкой и разнообразной эффективно функционирующей инфраструктуры, затруднительно или практически невозможно развитие некоторых видов бизнеса (туристической деятельности, производство бытовых услуг, некоторые виды строительного производства).

Ко второй подгруппе относятся элементы так называемой социально - духовной среды. Именно они формируют психологический климат, общественные предпочтения, вкусы и пристрастия.

В социально-духовной среде можно выделить исторические традиции, присущие территориальному образованию, в границах которого концентрируется целевой сегмент потребителей, этические нормы, тип общественного устройства, мировоззрения и нравственные устои. К социально - духовной среде можно отнести национальные, расовые, религиозные особенности потребителей, обуславливающие специфику социального поведения и образа жизни.

Социальные элементы внешней среды формируют социальный базис предпринимательства в форме инфраструктурных объектов и спроса потребителей конкретных товаров. Эти же элементы приобретают особое значение при решении проблем конкуренции, определении конкурентоспособности фирмы на рынке. Известно, что наиболее действенным методами конкурентной борьбы являются ценовые и неценовые методы. При этом к неценовым методам относятся повышение качества товара и совершенствование его параметров, наиболее значимых для потребителя. Однако, по мере развития рынка, активизации предпринимательской деятельности и постепенного удовлетворения спроса на различные товары ставится задача использования дополнительных методов конкуренции. К числу таких методов можно отнести конкуренцию, основанную на укреплении имиджа и общественном признании фирмы производителя. Такие методы наиболее эффективны в рамках предметной (маркетинговой) конкуренции, когда товары, присутствующие на рынке близки или полностью идентичны по качественным характеристикам или высокая платежеспособность целевого рынка отодвигает на задний план ценовые факторы.

Конкурируя на основе имиджа, являющегося самостоятельной социально - 
психологической характеристикой, фирма концентрирует внимание на социальных (а точнее - социально - духовных) компонентах, на основе которых строится программа формирования общественного мнения по отношению к фирме, ее склонности и стремлению к решению общественных задач, предпринимательской этике и общей культуре. Реализация подобной программы обеспечивает создание дополнительных конкурентных преимуществ, объективно необходимых в активной конкурентной среде.

Внутренняя среда предпринимательства охватывает широкий круг элементов представляющих совокупность внутренних условий функционирования предпринимательской организации и полностью зависит от предпринимателя. Когда речь идет о внутренней среде предпринимательства, то имеется в виду:

наличие капитала (как собственного, так и инвестированного);

выбор объекта предпринимательской деятельности и организационноправовой формы хозяйственной деятельности;

организационная структура организаций;

рациональность и эффективность предпринимательской деятельности и т. д.

Когда речь идет о внутренней среде предпринимательской организации то подразумевается ее структура, охватывающая не только управленческий механизм, направленный на оптимизацию научно-технической и производственносбытовой деятельности, но и на совершенствование технологий реализуемых процессов, с помощью которых предпринимательская активность (энергия), материалы и информация преобразуется в конечный продукт предпринимательской организации.

При формировании внутренней среды предпринимательства обычно выделяют две ее составляющие: ситуационные факторы и элементы внутренней среды

Элементы внутренней среды - это составные части предприятия, необходимые для достижения изелей. Основные элементы внутренней среды представлены на рис. 2.2.

Cитуационные факторы внутренней среды предпринимательской организации - это внутренние переменные, которые создаются предпринимателем исходя из анализа внешней среды и используются для определения граничных условий функционирования предпринимательской организации [3]. К основным ситуационным факторам относятся:

цели предпринимательства;

этика и культура предпринимательской деятельности;

внутрифирменное предпринимательство (интрапренерство).

Рассмотрим их.

Понятие «цуель» на первый взгляд кажется понятным без дополнительного объяснения, имеющее, казалось бы, самоочевидный смысл, в действительности относится к числу сложных категорий социологии, философии, экономики, управления

Цель - идеальное мысленное предвосхищение результата предпринимательской деятельности. Это предмет устремления, заранее намеченный конечный замысел, ожидаемый результат действия предпринимателя, то во имя чего 


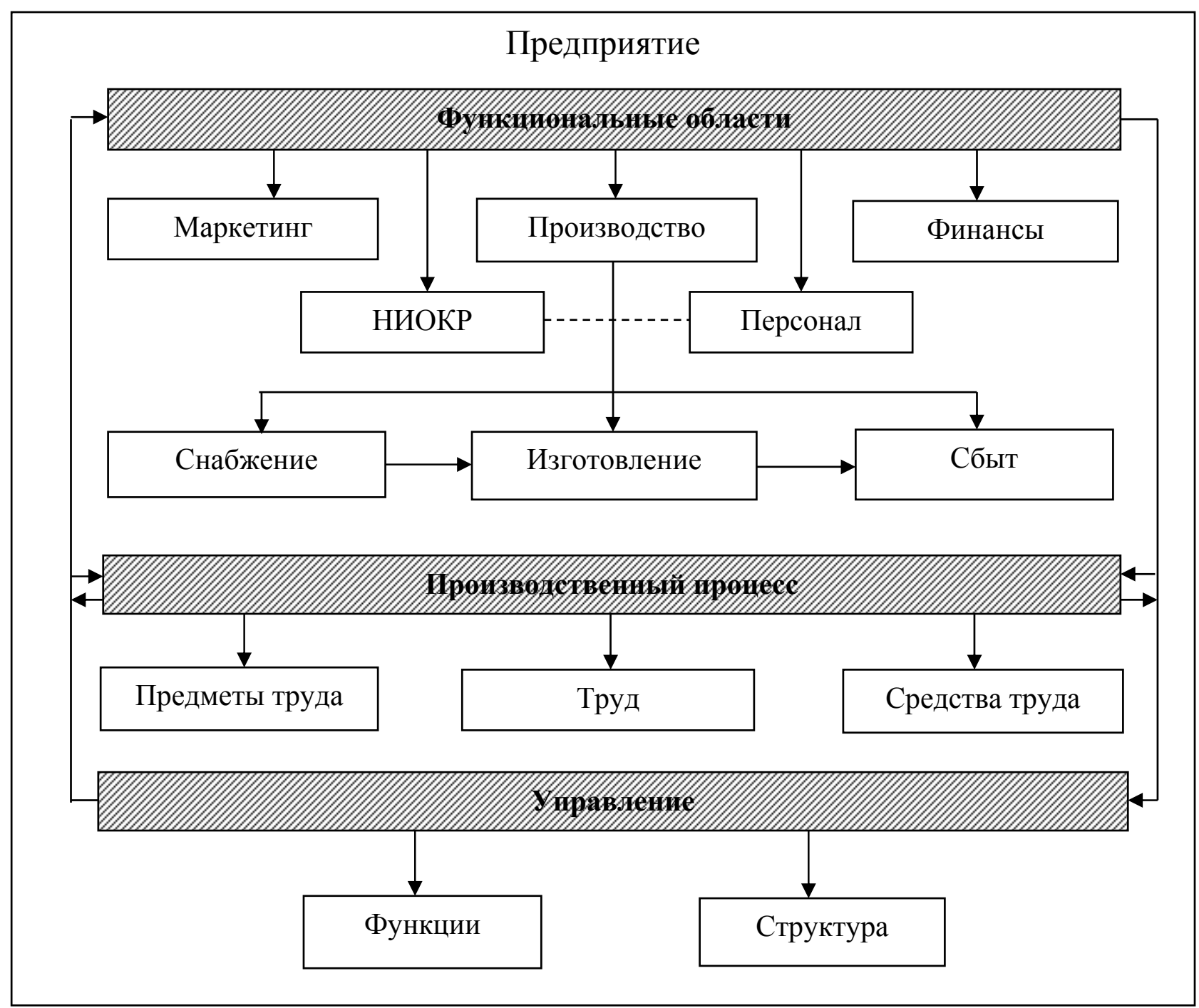

он работает. Родоначальник стратегического планирования и управления Игорь Ансофф определяет цель как критерий успеха или неудачи предпринимателя.

Рис. 2.2. Основные элементы внутренней среды [3] 


\section{2. Цели и задачи предпринимательской деятельности}

Цели направляют и регулируют предпринимательскую деятельность, поскольку вся ее деятельность направлена на их достижение ${ }^{1}$.

Процессы постановки и достижения, целей у предпринимателей постоянно сменяют друг друга рис. 2.3.

Новая цель для предпринимателя это стимулирующий фактор ${ }^{2}$. Однако, большей части предпринимателей необходимо признание достижения их успеха, они способны принимать на себя всю вину за неудачи.

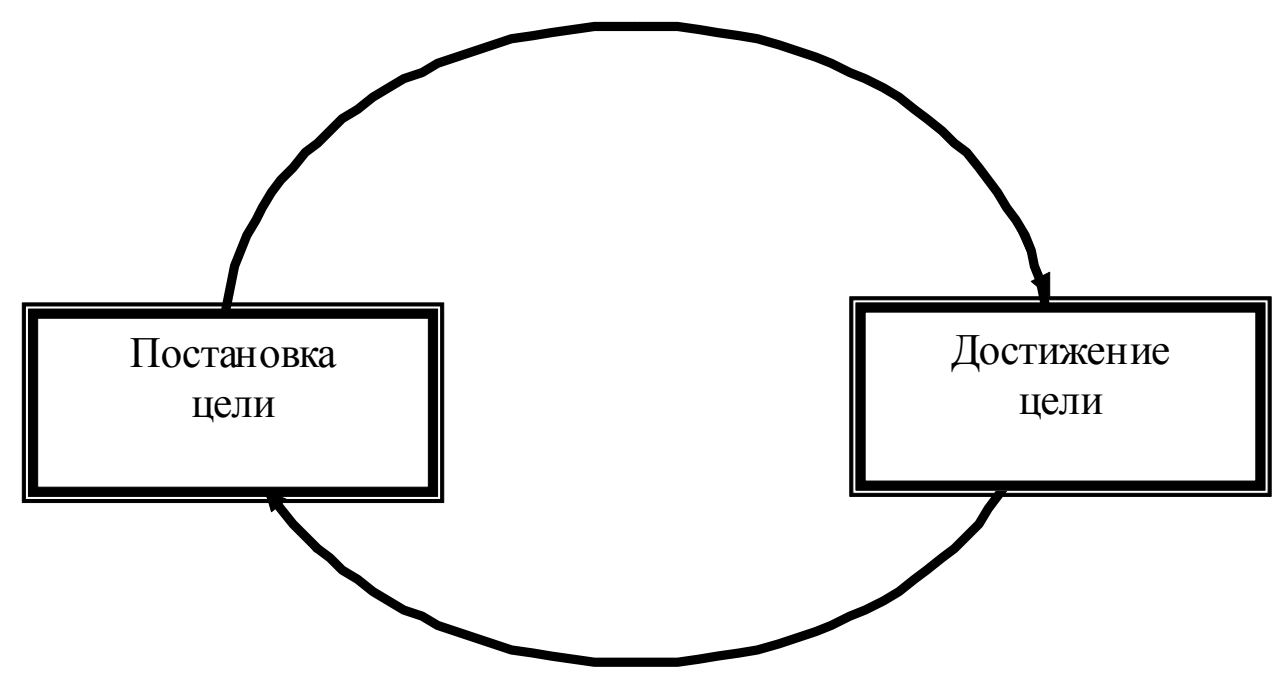

Рисунок 2.3. - Постановка предпринимательских целей

Основным вопросом, который должен разрешить предприниматель, является определение целей своей предпринимательской деятельности.

Если цели не определены, то их установление служит одной из самых главных и трудных задач управления предпринимательской деятельностью, составляющих предмет целеполагания. В этом случае формирование целей предпринимательской деятельности представляет первичную цель управления этой деятельностью, что наиболее ярко проявляется в планировании хозяйственной деятельности организации инвестиционного и финансовых процессов, управления затратами.

${ }^{1}$ Существует такое утверждение: счастье это стремление к значительным целям, но не обязательно их достижение. Это высказывание можно применить и к некоторым предпринимателям, которые, видя цель впереди уже счастливы, реализация этих целей для них необязательна.

2 «Рефлекс целей есть основная форма жизненной энергии каждого из нас. Жизнь только того прекрасна и сильна, кто всю жизнь стремится к постоянно достигаемой, но никогда не достижимой цели. Вся жизнь, все ее улучшения, вся ее культура делается людьми, стремящимися к поставленной ими в жизни цели» (И.П. Павлов, русский ученый-физиолог). 
Главная цель предпринимательской деятельности, которая обусловлена самой сущностью предпринимательства, заключается в стимулировании и удовлетворении спроса общества на конкретные потребности его членов (региона, страны). Однако это не единственная цель предпринимательства и помимо нее существует целая система различных целей (в том числе и частных, но не менее важных).

Главная иель предпринимателя - максимизация его возможностей удовлетворять комплекс социально-экономических потребностей предпринимателя в условиях неопределенности, она конкретизируется под влиянием внешней среде, исходя из возможностей внутренней среды и из его прошлого, а также из выполняемых предпринимательской единицей (ПЕ) функций.

Для того чтобы сохранить жизнеспособность и эффективность ПЕ, предприниматель должен ставить перед собой определенные цели точно так же, как он это делал до его создания. Эти цели могут быть различны. Наиболее типичными являются.

Цели развития ПЕ заключаются в изменении количественных параметров и качества функционирования ПЕ для перевода в желаемое, более благоприятное состояние, характеризуемое лучшими значениями целевых показателей. Цели развития могут состоять в определении финансированного ею уровня качества и эффективного производства, выхода на определенный уровень производства и потребления, удовлетворения потребностей потребителей.

Цели поддержания ПЕ в достигнутом ею состоянии возникают в условиях, когда надо закрепить это состояние потому, что оно удовлетворяет предпринимателя, либо вызвано опасностью ухудшения этого состояния, которую надо предотвратить.

Цель выхода из не желаемого состояния или цели дальнейшего спада, обеспечение выхода из кризиса характерны для ситуации, когда параметры, показатели функционирования ПЕ существенно ниже нормативного уровня, не удовлетворяют, целевым установкам предпринимателя и запросам потребителей, значительно хуже состояние аналогичных объектов. Целью предпринимателя в этой ситуации является преодоление спада, недопущения показателей предельно допустимого уровня, в стабилизации социально-экономической обстановки и создание предпосылок подъема.

Наряду с этим достаточно общими, глобальными целями возможны и вполне реальные более узкие, локальные цели, распространяющиеся на отдельные сферы, виды не только предпринимательской, но и социальной деятельности связанные с решением частных проблем, осуществлением проектов, программ.

Например, в качестве целей могут быть:

накопление денежных средств для завоевания новых рынков и развития производства;

улучшение социальных условий сотрудников ПЕ;

оптимизация спроса покупателей на продукцию ПЕ;

оказание помощи в улучшении этических и моральных норм общества, улучшение культуры потребления и т.д.

Как правило, такие локальные ограниченные цели, подчинены и входят в со- 
став перечисленных выше общих целей предпринимателя, соответствующих общественным целям.

Но цели ПЕ, не едины и не всегда совпадают с целями учредителей, менеджеров и коллектива. Более того, может наблюдаться противоречивость целевых устремлений внутри ПЕ, что наиболее типично в предпринимательстве. Несовпадение и противоречивость интересов людей, являющихся членами ПЕ может привести и приводит к разрушительным для ПЕ последствиям.

Наиболее опасны в этом отношении расхождения целей предпринимателя и членов коллективов ПЕ прикрываемые демагогическими заверениями предпринимателей о том, что они действуют в интересах коллектива. Истинные цели предпринимателя оказываются при этом завуалированными, скрытыми, ПЕ теряет целевую ориентацию и вместо того, чтобы организовать и ориентировать ее на достижение единых целей, вносят дезорганизацию ${ }^{1}$, приводят к низкой эффективности функционирования, а то и к деструкции ${ }^{2}$, банкротству ПЕ.

Решающим условием развития ПЕ является единство, не противоречивость целей предпринимателя и членов коллектива ПЕ. Естественно, что достижение полного соответствия целей не представляется возможным. Но должны существовать гармония интересов, определенный уровень совпадения целевых установок всех участников предпринимательской деятельности, переход за пределы которых недопустим.

Цели предпринимателей зависят от внешней среды, а выбор внешней среды выбирается предпринимателем в зависимости от целей.

Цели любой ПЕ (т.к. в ней протекают социально-экономические процессы) существенным образом связанны с потребностями людей и их удовлетворением. Любой экономический субъект, начиная от индивидуального предпринимателя, МП и завершая экономикой страны, функционирует, действует во имя потребления различных людей. Как известно, потребность - это нужда, необходимость в потреблении, использовании определенного количества товара и услуг, обеспечивающих жизнедеятельность приносящих людям удовлетворение их желаний. В конечном счете - именно удовлетворение количественно и качественно видоизменяюшихся потребностей людей, всего населения и составляет главную ичель экономики а, следовательно, и предпринимательской деятельности.

Цели ПЕ, (за исключением корпоративных структур) имеют ограниченный временной горизонт. Например, для предпринимателя, реализующего идею по выпуску инновационной продукции, цель которой поднять предпринимательскую организацию до уровня, при котором ее можно будет выгодно продать (чтобы воплотить в жизнь другую предпринимательскую идею), временной горизонт ограничен моментом продажи или слияния, так как после этого появляется новые ресурсы и новые перспективы.

Цели могут быть краткосрочными и долгосрочными.

Долгосрочные - это те цели, которые решают в течении длительного периода времени. Поэтому долгосрочные цели, направленные на поддержание и уве-

\footnotetext{
${ }^{1}$ От лат. destructivus - разрушительный, неплодотворный.

${ }^{2}$ От фр. desorganisation - нарушение порядка, дисциплины, нормальной деятельности.
} 
личение рентабельности должны подкрепляться решениями об обеспечении ресурсами таких долгосрочных потребностей, как исследования и разработка (НИОКР), создание новых производственных площадей и приобретение оборудования, обучение персонала.

Если бы поведение предпринимателя определялось исключительно ближайшими целями, подобного рода затраты были бы не оправданы. Поэтому важно, чтобы долгосрочные цели, направленные на поддержание и увеличение рентабельности, устанавливались по окончании краткосрочного периода развития.

Ближайшие и долгосрочные цели дают оценку товарно-рыночным возможностям в свете тенденций в отрасли и в экономике. Но в жизни присутствуют и непредвиденные обстоятельства, вероятность которых может быть относительно низка, но воздействие на рентабельность ПЕ - огромно. Это влияние может быть как негативным, приводящее к катастрофическим последствиям (война в Ираке принесла значительные потери для фирм которые в эту страну вложили инвестиции), так и позитивным открывающее перед ПЕ широкие перспективы, так, например дефолт в 1997 г. «сыграл на руку», например, производителям сухих строительных смесей.

Страхование может уменьшить риск, а новаторство осуществить «прорыв». Для этого необходимо поставить еще одну цель - гибкость ПЕ. Гибкость может быть внешней, которая достигается применением диверсификационной модели товарно-рыночных инвестиций, минимизирующей последствия и гибкость внутренняя, выражающаяся в ликвидности ресурсов ПЕ.

Любая цель как критерий успеха (или неудачи) состоит из трех элементов:

некоего атрибута призванного проверять выполнение критерия, средства измерения или масштаба, для оценки величины атрибута и задачи определенного значения, масштаба, которого стремиться достичь ПЕ.

Если взять основную цель предпринимательской единицы ее атрибут стимулирование и удовлетворение спроса общества на конкретные потребности его членов, то средством измерения будет норма прибыли на всем временном горизонте, а задачей - оптимизация этой нормы.

Прибыль является оценкой успеха и психологическим стимулом предпринимателя, показателем эффективности использования ресурсов и оценки инвестиционных возможностей, и соответственно источником развития предпринимательства. Именно по этому предпринимателю необходимо сосредоточить свои усилия на тех факторах, которые производят прибыль (а не на самой прибыли).

Для достижения целей определяются и решаются конкретные задачи предпринимательской деятельности в рамках текущей или перспективной политики ПЕ, которая определяет направление и методы осуществления предпринимательской деятельности, ее стиль. Все это обеспечивает эффективное поведение ПЕ в сложившихся или меняющихся условиях окружающей среды.

Задачи предпринимательской деятельности и их решение, способствующие достижению поставленных целей, можно разделить на три направления. Первое направление - это комплекс задач, решение которых обеспечивает успех инновационной деятельности предпринимателя, второе направление - это комплекс задач, решение которых формирует эффективность предпринимательской деятель- 
ности, которая осуществлялась или же только стала осуществляться, третье направление - предпринимательская деятельность должна быть не только эффективной, но и справедливой. Это происходит тогда, когда реализуется второе направление.

Прибыль является критерием того, насколько хорошо предприниматели удовлетворяют запросы клиентов. Как правило, чем выше прибыль, тем лучше удовлетворены потребности покупателей, и наоборот, чем ниже прибыль, тем меньше довольны покупатели. Увеличение нормы прибыли, например, требует решения комплекса таких задач, как обеспечение процесса производства необходимыми факторами производства; поиск источников финансирования; анализ выживаемости фирмы в меняющихся условиях конкуренции; удовлетворение потребностей покупателей или клиентов; увеличение объема продаж; оптимизация использования всех ресурсов; разработка маркетинговых стратегий; выбор поставщиков; выбор партнеров по бизнесу; повышение ликвидности фирмы; разработка мероприятий по охране окружающей среды и т.д.

Убеждение в том, что прибыль является единственной целью предприятия, является сомнительным и мало способствует его развитию. Основной проблемой предпринимателя является получение им достаточного дохода от использования ресурсов, а не максимизация прибыли. Не менее важным моментом в постановке задач является определение нормы возврата инвестиций в качестве средства измерения рентабельности.

Для того чтобы поставить перед собой разумные цели, предприниматель должен сначала оценить собственные силы и способности, определить наиболее эффективное направление своей деятельности. Самооценка - это творческий процесс при постановке целей, так как она может открыть перед предпринимателем интересные возможности завоевания новых рынков, сокращения или расширения номенклатуры продукции. Метод постановки целей с учетом собственных возможностей основывается на следующих положениях:

- в высококонкурентной экономике успех сопутствует в основном тем предпринимателям, которые работают на очень высоком профессиональном уровне, так как быть средним производителем почти так же рискованно, как и быть плохим;

- предприниматель должен способствовать формированию спроса на свою продукцию, привлекая новых покупателей (при условии, что выпускаемая продукция хорошего качества);

- продукция, работы или услуги могут быстро устаревать, но высокая репутация сохраняется годами.

После постановки целей предприниматель должен решить, каким образом лучше всего добиться их осуществления. Для этого он разрабатывает план действий, заключающийся в следующем:

- детальная разработка последовательных шагов достижения каждой цели;

- закрепление ответственности за осуществление каждого шага за предпринимателем или другой ключевой фигурой;

- определение контрольных сроков каждого шага.

План действий предназначен для осуществления задуманного. Без такого 
плана, способного вдохнуть жизнь в поставленные предпринимателем цели, они теряют смысл. Планированию предпринимательской деятельности посвящена глава 5. 


\section{3. Культурная средапредпринимательства}

Культура - это совокупность производственных, общественных и духовных потребностей людей, или высокий уровень чего-нибудь, высокое развитие, умение $^{1}$. Существует еще множество определений, однако, по сути, они сводятся к тому, что культура - это понятие интегрирующее различные аспекты жизни, деятельности, поведения людей, их объединений общества в целом на определенном историческом этапе своего развития.

Любая культура, том числе и предпринимательская содержит два основных аспекта: ценности и процедуры. Ценности - это этические идеалы, качества, являющиеся высшими нравственными категориями. Процедура - это официально зафиксированные и не писаные правила поведения, основанные на указанных ценностях.

В настоящее время используются термины «культура предпринимательства», «культура предприятия (фирмы)», «хозяйственная культура», «корпоративная культура », «организационная культура». Все эти идентичные понятия, под которыми понимается духовная жизнь людей в предпринимательской среде, в организации, их идейное нравственное состояние, ощущения, мышление и действия [6].

Хозяйственная культура - это как бы проекция экономики на сферу культуpы; верно также обратное утверждение, согласно которому она является проекиией культуры на сферу экономики. Другими словами, культурная компонента экономической деятельности (хозяйственная культура) неотделима от самой этой деятельности, является ее необходимой предпосылкой и способна активно воздействовать на нее, усиливая или замедляя развитие экономики. Точно так же можно утверждать, что экономическая составляющая культуры (хозяйственная культура) воздействует на всю культурную среду данного общества (включая науку, искусство, религию), причем прямо, непосредственно отражается на тех сферах культуры, которые наиболее тесно связаны с хозяйственной (таковыми являются правовая и политическая культура).

По отношению к хозяйственной деятельности культурная среда подразделяется на внешнюю и внутреннюю.

Внешняя культурная среда является составной частью макросреды, которая оказывает влияние на поведение субъектов хозяйственной деятельности.

Внутренняя культурная среда относится к микросреде субъекта хозяйственной деятельности и имеет отношение как к самой фирме, так и к партнерам, с которыми осуществляется взаимодействие.

Состав культурной среды характеризуется совокупностью факторов, к которым относят политику, технологию, образование, искусство, ценности и отношения, религию, язык, правоведение, социальный статус (рис. 2.4).

${ }^{1}$ С.И. Ожегов Словарь русского языка 


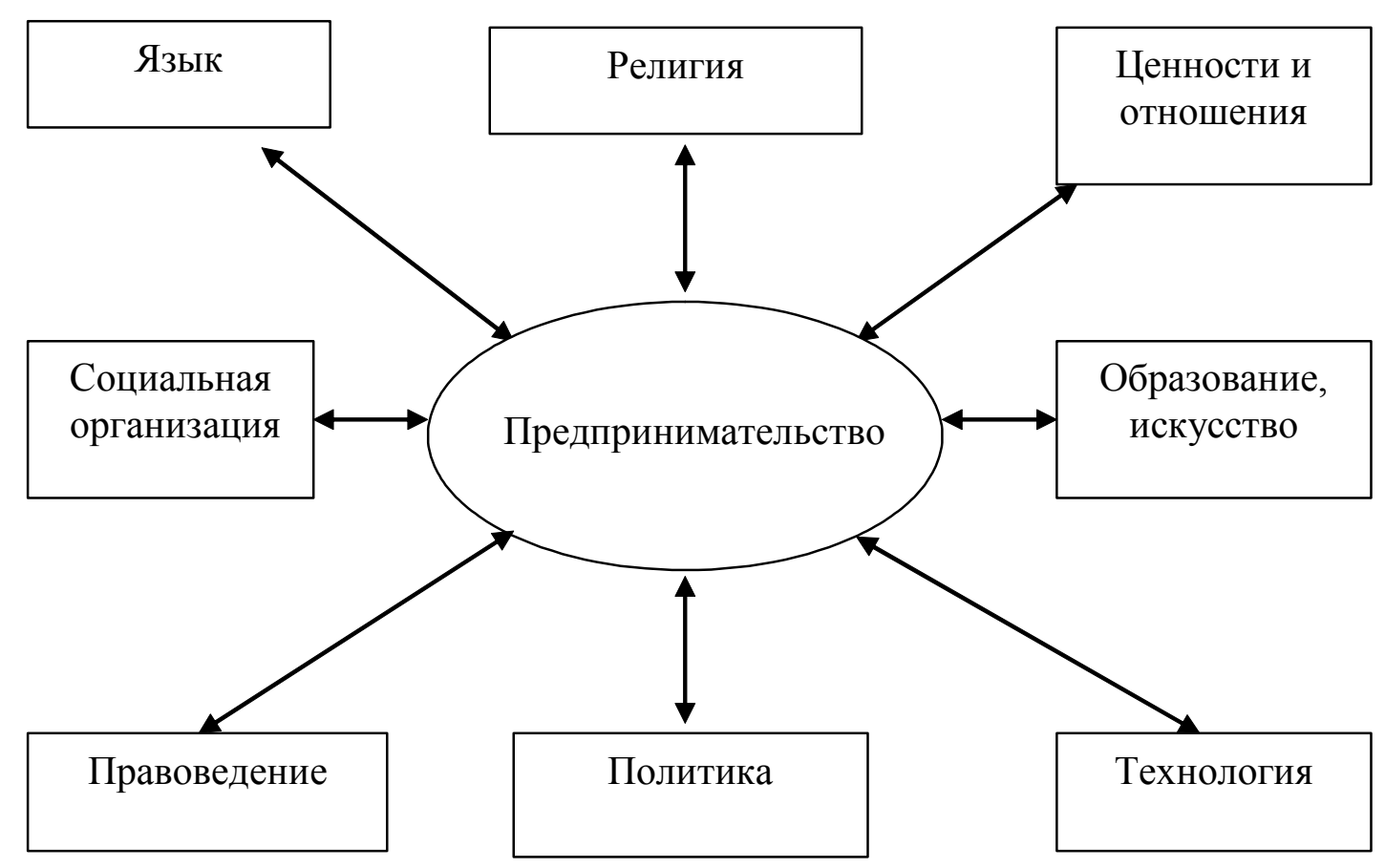

Рисунок $2.4-$. Состав культурной среды

Политика является всем известной категорией, однако не все предприниматели учитывают возможности этого фактора культуры в организации предпринимательства. Изучение политики может помочь понять потенциал общественного вклада той или иной страны в деловой климат фирмы. Стабильность политического климата, характеристики группировок, партий, поддерживающих зарубежный бизнес или препятствующих ему, степень влияния каждой из этих группировок - это те факторы, которые позволяют оценить степень предпринимательского риска в политическом отношении.

Технология - это область точных понятий, методов, измерений и знаний. Изучение технического уровня среды предпринимательства может дать информацию об уровне развития и потенциале рынка, о степени развитости его инфраструктуры, о том, какова степень урбанизации и развития "промышленных ценностей", а также выявить отношение к науке и нововведениям, установить научный потенциал, возможности проведения научных исследований

Образование и искусство, их уровень и профиль редко учитываются в организации предпринимательской деятельности. Однако сравнительный анализ этих факторов культуры может оказать помощь при изучении грамотности и ее влияния на техническое и профессиональное обучение, а также на эффективность рыночных связей и предпринимательских отношений. Образовательный уровень формирует к тому же отношение к ценностям, что целесообразно определять при формировании и развитии предпринимательской деятельности.

Технология - это область точных понятий, методов, измерений и знаний. Изучение технического уровня среды предпринимательства может дать информацию об уровне развития и потенциале рынка, о степени развитости его инфраструктуры, о том, какова степень урбанизации и развития "промышленных ценно- 
стей", а также выявить отношение к науке и нововведениям, установить научный потенциал, возможности проведения научных исследований.

Образование и искусство, их уровень и профиль редко учитываются в организации предпринимательской деятельности. Однако сравнительный анализ этих факторов культуры может оказать помощь при изучении грамотности и ее влияния на техническое и профессиональное обучение, а также на эффективность рыночных связей и предпринимательских отношений. Образовательный уровень формирует к тому же отношение к ценностям, что целесообразно определять при формировании и развитии предпринимательской деятельности.

Религия оказывает большое влияние на экономическую деятельность. Все основные религии - буддизм, ислам, христианство и др. - имеют несколько разновидностей (например, католицизм и протестантство). Своеобразный взгляд на мир и истинные ценности, как и отправление религиозных обрядов, может стимулировать или препятствовать стремлениям к переменам, применению новых методов в предпринимательстве. Для успешного осуществления предпринимательской деятельности необходимо учитывать развитость и роль религии в каждой стране, где планируется организация бизнеса.

Язык является основой, средством всех коммуникаций, в том числе и предпринимательских. На земном шаре имеется около 100 официальных языков и не менее 3000 самостоятельных диалектов.

В предпринимательской деятельности - как на национальных, так и на международных рынках - требуется знание нескольких языков. Английский язык является доминирующим, по меньшей мере, 2/3 деловой переписки в мире осуществляется на этом языке. Есть страны, где стремятся пользоваться только своим языком, например во Франции. Это следует учитывать при организации бизнескоммуникаций предпринимателям, бизнесменам, деловым людям.

Правоведение - знание законов своей страны, которые отражают нормы и правила отношений к ценностям, к собственности, защите личности, не должны восприниматься предпринимателями как второстепенный элемент культуры. Сравнение и знание различных систем законодательства могут способствовать пониманию традиций бизнеса в различных странах. Это может помочь избежать конфликтов, а в случае необходимости обратиться к органам правовой защиты.

Социальный статус населения, социальные особенности организации общества и первой его ячейки - семьи - в предпринимательстве имеют такое же значение, как и другие факторы культурной среды. Предприниматель в этом контексте должен знать, представляют ли его деловые партнеры семейные фирмы или же он будет иметь дело с профессиональными партнерами. Не менее важным является исследование социальной стратификации населения, чтобы установить, существует ли заметная разница между высшими, средними и низшими классами и каково их отношение к предпринимательству. Исследование и знание социальных особенностей общественных организаций позволяют установить, будут ли они содействовать или противостоять успеху в деятельности предпринимателя в конкретных социальных условиях.

Кроме того, хозяйственная культура всегда существует в определенных пространственных и конкретно-исторических условиях. Поэтому она испытывает 
воздействие и со стороны пространственных факторов (количественных и качественных) - особенностей климата, ландшафта, местонахождения страны, наличия в ней водных и иных путей сообщения, размеров ее общей и сельскохозяйственной территорий, их качества (полезные ископаемые, плодородие почвы и т.д.), и со стороны факторов временных (тот или иной период исторического развития данной хозяйственной культуры, этап воздействия на нее иных культур).

Так, в истории России наличие огромных неосвоенных пространств вызывало доминирование экстенсивного типа хозяйства над интенсивным; относительно суровый климат в сочетании с большим пространством предопределял необходимость коллективного, а не индивидуального хозяйствования. С этим во многом связана необычайная стойкость в России такой хозяйственной формы, как община, которая сохранилась здесь до ХХ столетия (даже после революции 1917 г. отдельные ее элементы были отчасти сохранены в колхозах, дойдя до наших дней). В данной связи можно утверждать: возникнув под воздействием географических и иных факторов, хозяйственная форма может, укрепившись, оказывать значительное воздействие как на структурные составляющие хозяйственной, правовой и политической культур, так и па религию, науку, искусство и другие специализированные области культуры. Это мы и видим на примере русской общины.

Как уже отмечалось, существенный момент содержания хозяйственной культуры - ценностное отношение к труду, богатству, накоплению, экономической деятельности вообще. Вовсе не случаен, скажем, факт возникновения и утверждения капитализма именно на базе протестантской этики, трактующей труд как высшую добродетель, а богатство - как благословение Божие, которое в то же время налагает на его владельца ответственность перед Богом. Наиболее систематично эту взаимосвязь выразил М. Вебер в своей классической работе «Протестантская этика и дух капитализма (1905), где впервые сформулированы проблемы «хозяйственной этики».

Известный русский мыслитель С.Н. Булгаков в начале прошлого века обращал внимание на известный факт близкой связи русского предпринимательства со старообрядчеством, из которого вышли представители целого ряда крупнейших российских предпринимателей. С его точки зрения, было бы «особенно интересно» вычленить и проанализировать «экономические потенции православия», которое коренным образом отличается от протестантизма. Православие, утверждал С.Н. Булгаков, располагает могучими средствами воспитания личности, выработки у нее чувства ответственности и долга, так необходимых для предпринимательской деятельности. «Нужно понять, что и хозяйственная деятельность может быть общественным служением и исполнением нравственного долга, и только при таком к ней отношении и при воспитании общества в таком ее понимании создается наиболее благотворная атмосфера как для развития производства, так и для реформ в области распределения, для прогресса экономического и социального» ${ }^{1}$.

В современных условиях, в условиях постиндустриального развития значимость культурных, ценностно-мотивационных факторов экономической деятель- 
ности резко повышается. Они в немалой степени определяют ныне экономический рост как на уровне отдельных хозяйствующцих субъектов, так и применительно к народнохозяйственному цуелому. В этой связи важно отметить следующее.

Вплоть до первой половины ХХ столетия воспроизводство культурной среды происходило в основном стихийно, и культура и целом действовала как «даровой ресурс». А формирование ценностной среды если и регулировалось сознательно, то лишь в сферах, удаленных от собственно хозяйственной - в идеологии, науке, искусстве (лишь в сфере образования отчасти имело место регулирование ценностной среды, приближенное к хозяйственным потребностям). Однако уже и 60 - 70-е годы (а в 80-х годах этот процесс усилился) воздействие государства и бизнеса на хозяйственную культуру приобретает плановый, скоординированный характер; оно превращается в национальную стратегию и даже закрепляется в сфере политической культуры. Пионерами в деле управления хозяйственной культурой внутри корпораций стали японские фирмы. Их пример принципиально нового отношения к культуре, воплощаемого в огромные прибыли, заставил и американские, и западноевропейские компании отказаться от присущего им «технократического» подхода. В середине 80-х годов более половины крупнейших американских корпораций перешло к управлению хозяйственной и организационной культурой. Среди высокоприбыльных компаний 88\% имели специальные подразделения, отвечающие за организацию внедрения «высших ценностей», 65 - специальные программы увязки этих ценностей с мерами по повышению производительности труда, 58\% - соответствующие целевые курсы для персонала.

В принципе управление трудовой этикой и хозяйственно-организационной культурой было известно и в средние века. Гильдии купцов, цехи ремесленников вместе с технологическими секретами мастерства имели определенные «кодексы чести», кодексы трудовой этики, которые передавались от отцов к сыновьям. Японские фирмы во многом возродили эти феодально-цеховые черты в своих внутренних отношениях, но сделали ставку в основном на коллективизм и единство служащих фирмы, тогда как в американских фирмах пытались стимулировать дух предпринимательской активности. Ныне имеет место как бы встречное движение хозяйственных предпринимательских культур Востока и Запада - Запад стремится развить в своих корпорациях принципы коллективизма и ценностного отождествления каждого работника с целями и организационно-хозяйственной культурой фирмы, а Восток пытается задействовать в рамках корпорации деятельные ипдивидуально-предпринимательские мотивации, без которых невозможна современная инновационно-предпринимательская культура.

Обобщая, можно сказать, что чисто «технократическое» понимание экономического роста, не учитывающее огромную роль культурной компоненты хозяйства, ныне преодолено и в развитых странах Запада, и в развивающихся странах Востока. Это и естественно, ибо управление хозяйственной культурой в целом и важнейшей се составляющей -ценностной мотивацией к труду, равно как и стереотипами хозяйственного поведения субъектов, - объективная насущная потребность и для мощных индустриальных держав, и для развивающихся государств, пытающихся мобилизовать заключенные в их культуре специфические традицио- 
налистские факторы в целях экономического развития и модернизации.

Однако уровень и размах управления хозяйственной культурой в странах с развитой рыночной экономикой и в странах с переходной (транзитивной) экономикой разумеется, весьма различны. Применительно к первым состояние этого вида управления диктуется высотой «постиндустриального развития», требующего не просто квалифицированного исполнителя, встроенного в иерархизованную бюрократическую структуру корпорации, а деятельного энергичного предпринимателя, имеющего определенную свободу и ответственность внутри корпорации, не отчужденного от нее, а личностно с ней слитого.

Становление подобного рода инновационно-предпринимательской культуры анализируется ныне и в теоретическом, и в организационно-прикладном плане, причем прикладные исследования зачастую опережают собственно научные разработки в этой области. В итоге «корпоративная этика» оценивается как «главный актив компании».

Новый тип личности, формируемый в корпорации, - это тип лидераносителя инновационно-предпринимательского духа, способного давать сотрудникам фирмы образцы социально значимого поведения в различных ситуациях, создавать новые и закреплять уже наработанные культурно-хозяйственные традиции (выдвижение такого рода лидеров в центр инновационной деятельности связано и с тем, что любое нововведение, ломая установившийся порядок, вызывает достаточно сильное противодействие).

Говоря об активном становлении хозяйственной культуры, прежде всего в крупных корпорациях, следует отметить и высший уровень формирования хозяйственной культуры - общенациональный, общегосударственный. С переходом к этому уровню расширяется и сама культурная среда и ее возможности. Государство определяет общенациональные цели, проводит «национальную политику», а также осуществляет социализацию экономики. В задачи национальной стратегии сегодня необходимо входят поддержка и распространение инновационной культуры, нередко на базе возрождения традиционных культурных ценностей (японская идея о возвращении к традициям, девиз Р. Рейгана «семья, труд, добрососедство» и т.д.). При этом фигура предпринимателя-новатора пропагандируется как образец для подражания, предпринимательская активность всячески облагораживается; налицо, таким образом, попытки возродить на новой основе старую хозяйственную этику, помогшую становлению капитализма. Внедрение на государственном уровне установок о ценности предпринимательства происходит практически во всех странах с развитой рыночной экономикой. Причем факт состоит в том, что данный процесс идет тем успешнее, чем выше консолидация общества.

Хозяйственная культура общества как особая специализированная сфера культуры всегда связана с деятельностью по производству жизни (жизнеобеспечением) и воплощена в таких своих носителях, как технологии, обычаи, нормы права; она кристаллизована в определенных институциональных структурах. Прежде всего, хозяйственная культура представлена в институциональной системе общественного разделения труда.

Деятельность людей по их жизнеобеспечению за пределами этой институци- 
ональной системы сопряжена с обыденной хозяйственной культурой (это, например, ведение подсобного хозяйства). Исторически на базе соответствующих стихийно складывавшихся образцов хозяйствования и взаимоотношений постепенно складывалась особая, институционально оформленная и закрепленная, отрефлексированная специализированная хозяйственная культура, имеющая своих конкретных субъектов.

Субъектами специализированной хозяйственной культуры в современном индустриальном («постиндустриальном») обществе выступают, с одной стороны предприниматели - менеджеры с другой, - ученые (экономисты, социологи, юристы, культурологи и т.д.). Первая указанная группа субъектов создает инновации в хозяйственной культуре самой своей деятельностью. Вторая - рефлексирует результаты этой деятельности, выделяет общее поле соответствующей исследовательской активности, выявляет тенденции и перспективы развития специализированной сферы культуры, предпринимательской культуры, корпоративной куль$m y p b l$ - намечает программы усиления в ней динамического элемента и т.п.

Уже в раннем средневековье в цехах ремесленников складывались особые специализированные подсистемы хозяйственной культуры со своей этикой, точной и строгой регламентацией профессионального мастерства, параметров качества изделий и т.п. С переходом к буржуазному строю, к индустриализму окончательно выкристаллизовывается особая специализированная сфера хозяйственной культуры, касающаяся всего общества, а не отдельных лишь его подсистем. Хозяйственная культура универсализируется, национальные культуры приобретают черты, характерные для промышленной стадии развития.

Рассматривая пути модернизации ведущих европейских стран, уже находящихся на «постиндустриальной» стадии развития, нетрудно выделить три основные модели развития хозяйственной культурыл.

Первая - англо-американская модель модернизации. Она предполагает, в частности, развитие фермерства и наличие свободной рабочей силы для потребностей промышленности. Различия в формах фермерства (в Англии преобладающим выступал тип фермера- арендатора, а в США - свободного фермера) не меняет общности типа модернизации. Вторая модель, характерная для южноевропейских и среднеевропейских стран, в том числе для Франции и Германии, отличается исторически сложившимся крупным классом мелкого крестьянства. Она характеризуется замедленными темпами модернизации. Так, как во Франции лишь после второй мировой войны городское население стало преобладающим по отношению к сельскому; не смотря на то, что французский промышленный переворот развернулся всего лишь на полстолетия позже английскою, страна долгое время не могла превратиться в индустриальную державу и оставалась аграрно-индустриальной.

Германия вступила па путь промышленного переворота на столетие позже Англии; когда уже складывались английская и французская фабрично-заводская индустрии, в Германии доминировало средневековое ремесленное производство. Однако более поздняя индустриализация имела и свои преимущества. Если во Франции промышленный переворот строился на основе поставок английских машин, в Германии он был осуществлен на базе собственного машиностроения: 
здесь сразу создавались крупнейшие для своего времени предприятия этой отрасли. Получив преимущества перед устаревшим машинным парком английской промышленности, германская индустрия стала развиваться небывалыми для XIX столетия темпами ${ }^{1}$.

Третья модель свойственна развивающимся странам «третьего мира», вступившим на путь модернизации почти на столетие позже, чем основные европейские государства. Этот тип модернизации объединяет страны с различной хозяйственной культурой. И, конечно, культурно-хозяйственное своеобразие накладывает свой неповторимый отпечаток на вид модернизации в рамках этого типа, хотя общим остается «вторичный» («вдогонку») характер модернизации, попытка быстрого перехода традиционных в своей основе обществ на путь индустриального развития. Один из таких видов являют страны Латинской Америки, имеющие свои специфические черты модернизации и свойства хозяйственной культуры. Особо должны быть выделены также новые юго-восточные «драконы» (например Южная Корея), модернизация которых сопрягалась с широким доступом к современной американской технологии, с крупными вложениями американского капитала.

Отечественная модель модернизации заключается в том, что, хотя первичная индустриализация (промышленный переворот и развитие капитализма) была осуществлена в России в основном по второй модели модернизации (европейской: во многом подобно немецкой), а в некоторых параметрах подобно французской, дальнейшее российское экономическое развитие, прерванное мировой войной и революцией, пошло но особому пути, в истории прежде не встречавшемуся.

Переходное состояние российской экономики предопределяет взаимосвязь специфических симбиозно взаимодействующих и противоречащих друг другу элементов системы экономических отношений. Здесь еще присутствуют компоненты старой административно-командной системы с присущими ей чертами и особым складом общественною сознания. Становящиеся институты рыночной экономки, первоначальное накопление капитала, проходящее в принципиально иных условиях, когда капитал формируется не в процессе длительной эволюции посредством капитализации дохода, а в основном путем деления государственной собственности и на основе принципа «больше получает тот, кто ближе к государственной власти», и не в период зарождения и становления нового общественного строя, где преобладает мелкотоварное производство, а в индустриальную эпоху, когда концентрация капитала достигла невиданных размеров, а рынок свободной конкуренции уступил место монополистической конкуренции в различных формах ее проявления, исторического этапа бурного развития научно-технического прогресса и повышения роли человеческого фактора, усложнения практики предпринимательства и возникновения новых закономерностей тенденциях его развития.

${ }^{1}$ Важнейшим стимулом хозяйственного прогресса выступила и национально-культурная идея объединения Германии под эгидой Пруссии. Создание единой железнодорожной сети создало экономические предпосылки хозяйственной интеграции немецких земель, ускорило развитие важнейших отраслей промышленности (выплавка стали, добыча угля, производство машин). 
Предпринимательство как особая сфера социальной деятельности со своими нормами, ценностями, правилами, традициями, предрассудками и т. д. формирует и воспроизводит свою особую субкультуру - предпринимательскую. В предпринимательской культуре присутствует своя этика и свой этикет, свой язык, свои принципы идентификации, включения и исключения.

Этика ${ }^{1}$ - система норм нравственного поведения и обязанностей людей по отношению друг к другу и обществу в целом.

Этика деловых отношений - это система универсальных и специфических нравственных требований и норм поведения, реализуемых в профессиональной деятельности.

В нее входят:

этическая оценка внутренней и внешней политики организации;

моральные принципы членов организации;

моральный климат в организации;

нормы делового этикета.

В каждой компании имеется определенная система общепризнанных нравственных процедур (норм, ценностей, знаний) обязательных для всех участников предпринимательской деятельности. Ядро корпоративной этики формируется основателями организации и непосредственно связано с их жизненным опытом и мировоззрением. Репутация и авторитет руководителя, эффективности его работы воспринимается подчиненными как данность, и они, в той или иной мере начинают подражать ему. Любой человек, решивший стать предпринимателем, т.е. начать свое дело, войти в мир бизнеса, уже только по этому является личностью не ординарной.. И качества этой личности начинают реализовываться, проецироваться на создаваемую им предпринимательскую организацию. Именно в человеческом взаимодействии и формируются корпоративные этические ценности.

Этика национального хозяйствования формируется совместными усилиями в этой сфере государства, деловых кругов, профсоюзного, гражданского общества и церкви ${ }^{2}$

Под предпринимательской этикой принято понимать свод неких моральных критериев, норм, нравственных параметров в поведении предпринимателя, о требованиях, предъявляемых культурным сообществом к стилю его работы, характеру общения с людьми, социальному облику.

Выросшее на базе властных полномочий российское предпринимательство связывает завоевание конкурентных преимуществ не с реализацией новаторской функции; предпринимательский успех усматривается, прежде всего, в реализации имеющегося административного ресурса. Достижение своих целевых установок

1 Аристотель определял понятие «этика» как «добродетели или достоинства, проявляющиеся в поведении человека» и считал, что этика «помогает познать, что следует делать и от чего следует воздерживаться».

2 VII Всемирный русский народный собор проходивший в 2002 г. по теме: «Вера и труд: духовно-культурные традиции и экономическое будущее России» в итоговом документе - Соборном слове заявил о том, что разработка этики национального хозяйствования, основанной на православных ценностях, является важнейшей задачей для современной России. 
предприниматель связывает с взаимодействиями, покоящимися не на рациональном действии, а на наличии личностных связей и персонифицированном доверии. При этом определяющим фактором формирования конкурентной устойчивости является не рационализация деятельности, а укрепление монопольного положения за счет получения исключительных прав, привилегий и льгот. Неудивительно поэтому, что для российских фирм при найме управляющих высшего звена определяющим моментом является не квалификация, а наличие у кандидатов личностных связей среди участников рынка и в государственных органах,

Предпринимательская культура отличается от других статуснопрофессиональных субкультур, например журналистской или офицерской или профессиональной культурой государственных служащих и т. д.

Предпринимательская культура часто имеет этнический оттенок, например русское «честное купеческое слово». Предпринимательская культура имеет собственное ядро - предпринимательские ценности, связанные со стремлением к прибыли, готовностью к риску, инновационностью, самостоятельностью и ответственностью, основанной на справедливости.

Правда, в отечественной практике произошло наоборот - приспособление самих условий хозяйствования к нуждам организации. В этом случае сформировалась соответствующая культура предпринимательства, опирающаяся не на рациональность поведения, а на личностные связи и бюрократические механизмы, где главным инструментом конкуренции служит возможность реализации административного ресурса.

Таким образом, это еще раз подтверждает тот факт, что условия, в которых осуществляется предпринимательская деятельность напрямую воздействуют на предпринимательскую культуру.

Особо следует отметить, что предпринимательская культура должна базироваться на таком важном принципе как справедливость. Предпринимательская деятельность обязательно должна быть не только эффективной, но и справедливой. В данном случае предпринимательская деятельность содействует поддержанию жизни тех, кто сам не может производить материальных ценностей, и тех, кто не должен производить такие ценности по роду своей деятельности, важный для общества и государства не в меньшей степени, чем работа, направленная на производство материальных благ.

Предпринимательская культура сохраняет поддерживает и развивает инновационную культуру, ту часть культуры общества, которая более всего развита именно у предпринимателей. Необходимо отметить, новаторский тип предпринимательской культуры обусловлен не внутренней эволючией организации, а был реакцией на изменение внешней среды-рыночных условий осуществления предпринимательской деятельности готовность к риску, потребность кинновации и активный поиск ее - все эти необходимые элементы является частью общечеловеческой культуры. 


\section{4 Внутрифирменное предпринимательство (интрапренерство)}

В настоящее время не только в теоретических исследованиях, но и на практике уделяется больше внимание не только предпринимательству как особому виду хозяйственной деятельности в условиях концентрации и создания для себя лучших условий хозяйствования посредством рыночного обмена, но и внутрифирменному предпринимательству - интрапренерству'. Необходимо обратить внимание на то, что внутреннее предпринимательство следует рассматривать как внутренний переменный ситуациональный фактор, который задается руководителем организации исходя из анализа внешней средь и используется для достижения организацией конкурентных преимуществ.

Выделение интрапренерства как особого вида предпринимательской деятельности, лишает предпринимательство бытия, превращая его в то « возникающий, то исчезающий фактом»²

Возникновение интрапренерства (рис. 2.5), во-первых, обусловлено объективными тенденциями социально-экономического развития общества, когда доминирующими для многих становятся социальные аспекты мотивации деятельности человека, когда люди стремятся к самостоятельности, самовыражению. Они хотят реализовать эти потребности, получить больше самостоятельности в своей организации в рамках ее организационной структуры. Недооценка этих желаний может привести к снижению интереса к выполняемой работе и уходу из организации наиболее способных и перспективных работников в поисках возможности для самореализации и творчества.

Во-вторых, причиной интереса к интрапренерству стала тенденция появления новых технологий, которые необходимо внедрять с целью увеличения конкурентных преимуществ.

В крупных организациях работающих достаточной стабильно и успешно, как правило, сдерживается новаторство, блокируются нововведения, могут игнорироваться инициативы, особенно, если они не связанны непосредственно с основной деятельностью организации, т.е. наблюдается консерватизм.

${ }^{1}$ Термин «интрапренер» был введен в оборот американским исследователем Г.Пиншо и в дальнейшем получил развитие:

entrepreneur - человек, который идет на риск при создании новой организации или внедрении новой идеи, продукта или услуги.

entrepreneurship - предпринимательская деятельность, проводимая внутри крупной фирмы или иного большого делового предприятия

entrepreneurial manager - менеджер, который изыскивает возможности и идет на преднамеренный риск, осуществляя изменения и вводя усовершенствования на своем предприятии.

${ }^{2}$ Штайльманн К Новая философия бизнеса T II. Риски и успех предпринимательства в постсоциалистическом обществе. - Москва-Берлин: Российское психологическое общество, 1998-с 175 предпринимательство в XX веке. Под ред. А.А. Дынкина. М.: Наука, 1992- с. 312 Милер А.Е., Чуканова С.Н. Интрапренерство - Омск: Изд-во Омского ун-та, 1998 
Организации с традиционной структурой управления, как правило, действуют на основе четкого иерархического соподчинения и набора инструкций, всесторонне регламентирующих их жизнедеятельность.

В организациях предпринимательского ${ }^{1}$ типа руководителем создается атмосфера поиска, поощряются выдвигаемые идеи, предложения и новые решения. Развитие духа интрапренерства обеспечивает эффективное развитие предпринимательской организации и позволяет достичь конкурентных преимуществ в сравнении с другими организациями.

С социально-психологических позиций предпринимательская деятельность - это средство реализации потребностей личности в независимости, богатстве, престижной работе, положении в обществе. В некоторых организациях создаются условия для превращения человека, выдвинувшего предпринимательскую идею, в совладельца фирмы - партнера, существуют и другие виды заинтересованности. Индивидуальный предприниматель может реализовать эти потребности полностью. В партнерском бизнесе они несколько ограничены, поэтому в предпринимательской организации для интрапренера должны быть созданы определенные условия, обеспечивающие реализацию его новаторских идей (рис. 2.6).

Под внутрифирменным предпринимательством понимается реализация предпринимательских целей внутри существующей коммерческой организации, выпускающей определенную продукцию (работы или услуги), в которой руководителем создаются условия для выдвижения и реализации новаторских предпринимательских идей по коммерциализации новых технических, технологических и иных достижений для чего выделяются ресурсы (интракапитал) $)^{2}$ - для их реализации и оказывается всесторонняя помощь для практической реализации идеи.

1 Предпринимательская организация - это организация, которая активно идет на реализацию всех возможных предпринимательских идей.

${ }^{2}$ Интракапитал - капитал, необходимый для реализации и идей, лежащих в основе внутрифирменного предпринимательства 


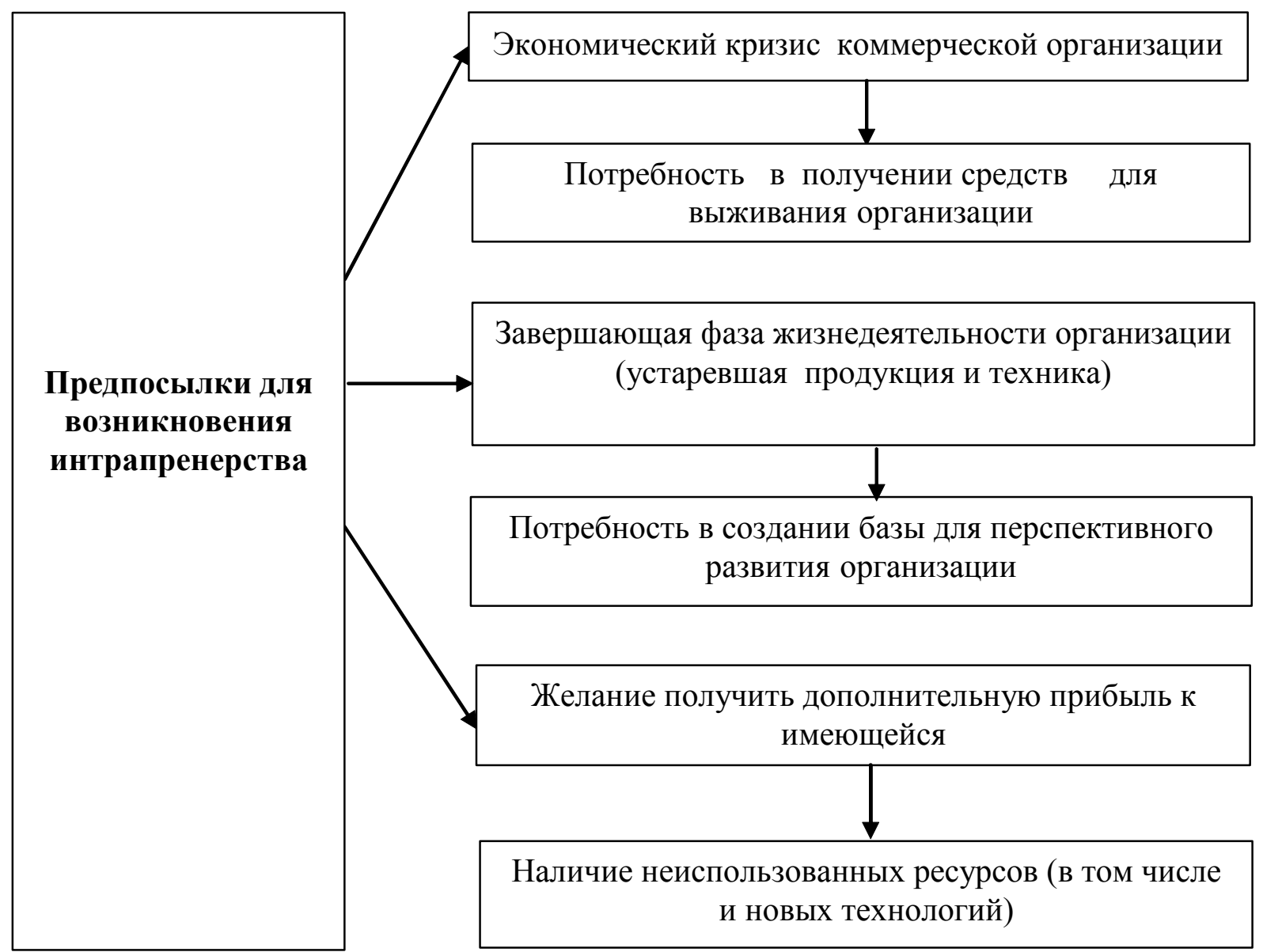

Рисунок 2.5 - Потребности, формирующие предпосылки для возникновения интрапренерства

Внутрифирменное предпринимательство можно рассматривать как деятельность по производству и реализации продукции (работ) на основе интеграции предпринимательской инициативы и возможностей коммерческой организации. Таким образом, человек, инищиирующий и ведущий свою предпринимательскую деятельность в рамках действующей организации - это интрапренер.

Сущность деятельности интрапренера состоит в том, что он не ждет каких либо изменений в деятельности организации и лишь потом реагирует на них соответствующим образом, а «заставляет» происходить выгодные для коммерческой организации изменения, т.е. перестраивает обычный процесс в предпринимательский, инновационно-интрапренерский.

Главной целью внутрифирменного предпринимательства является стимулирование и удовлетворение спроса общества на конкретные потребности общества в рамках существующей коммерческой организации.

Главной целью интрапренера является максимизация его возможностей в условиях действующей коммерческой организации

Цели внутрифирменного предпринимательства формируется в условиях внутренней среды коммерческой организации под воздействием внешней среды. 


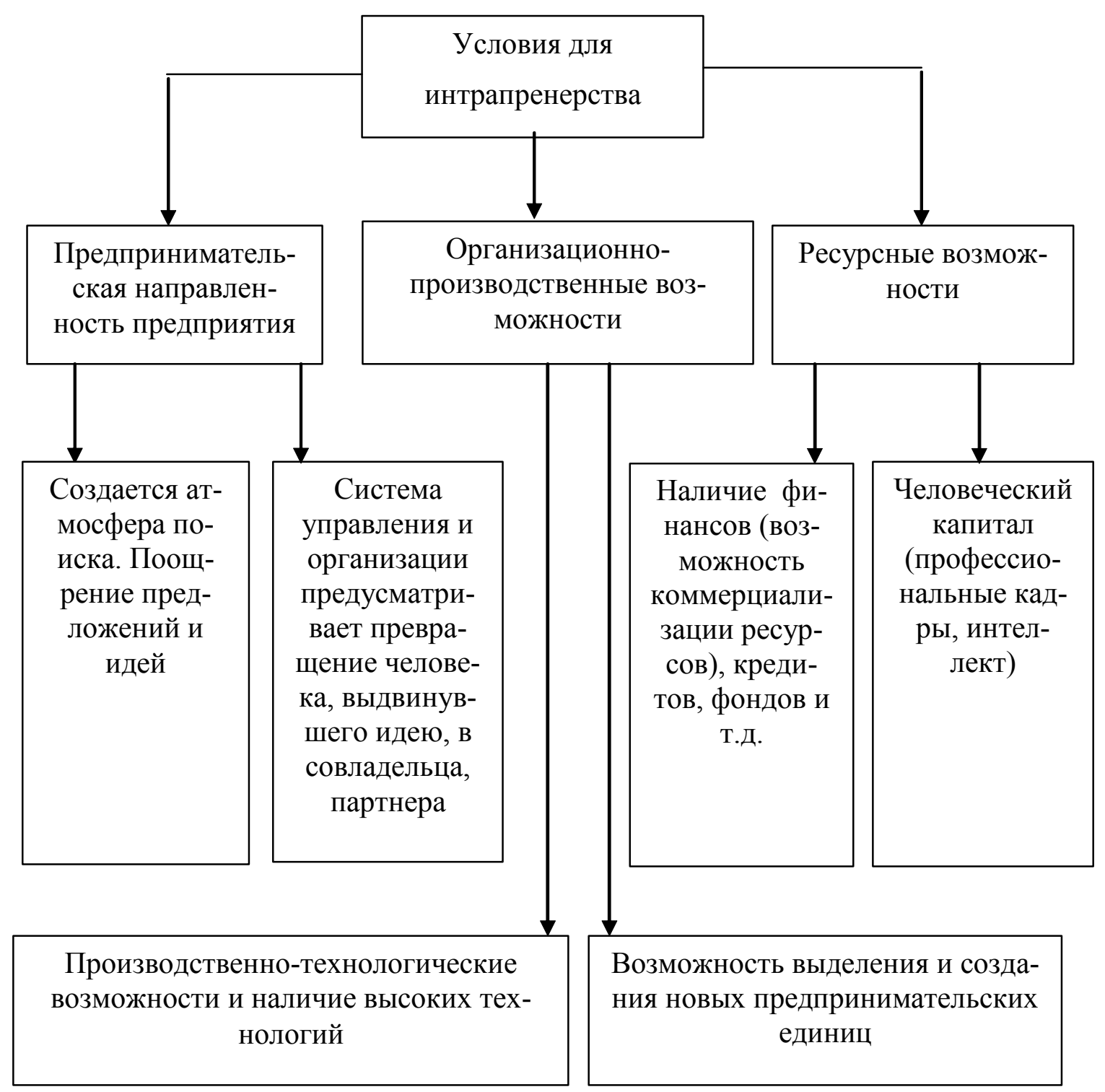

Рисунок 2.6-. Условия для возникновения партнерства интерпартнера и организации предпринимательского типа

потребность в получении денежных средств для устойчивого развития коммерческой организации;

потребность в создании ресурсной базы для перспективного развития коммерческой организации;

желание получить дополнительную прибыль к имеющейся.

Также целью внутрифирменного предпринимательства является обеспечение интересов - организации и интрапренера выдвинувшего и реализовавшего предпринимательскую идею. 


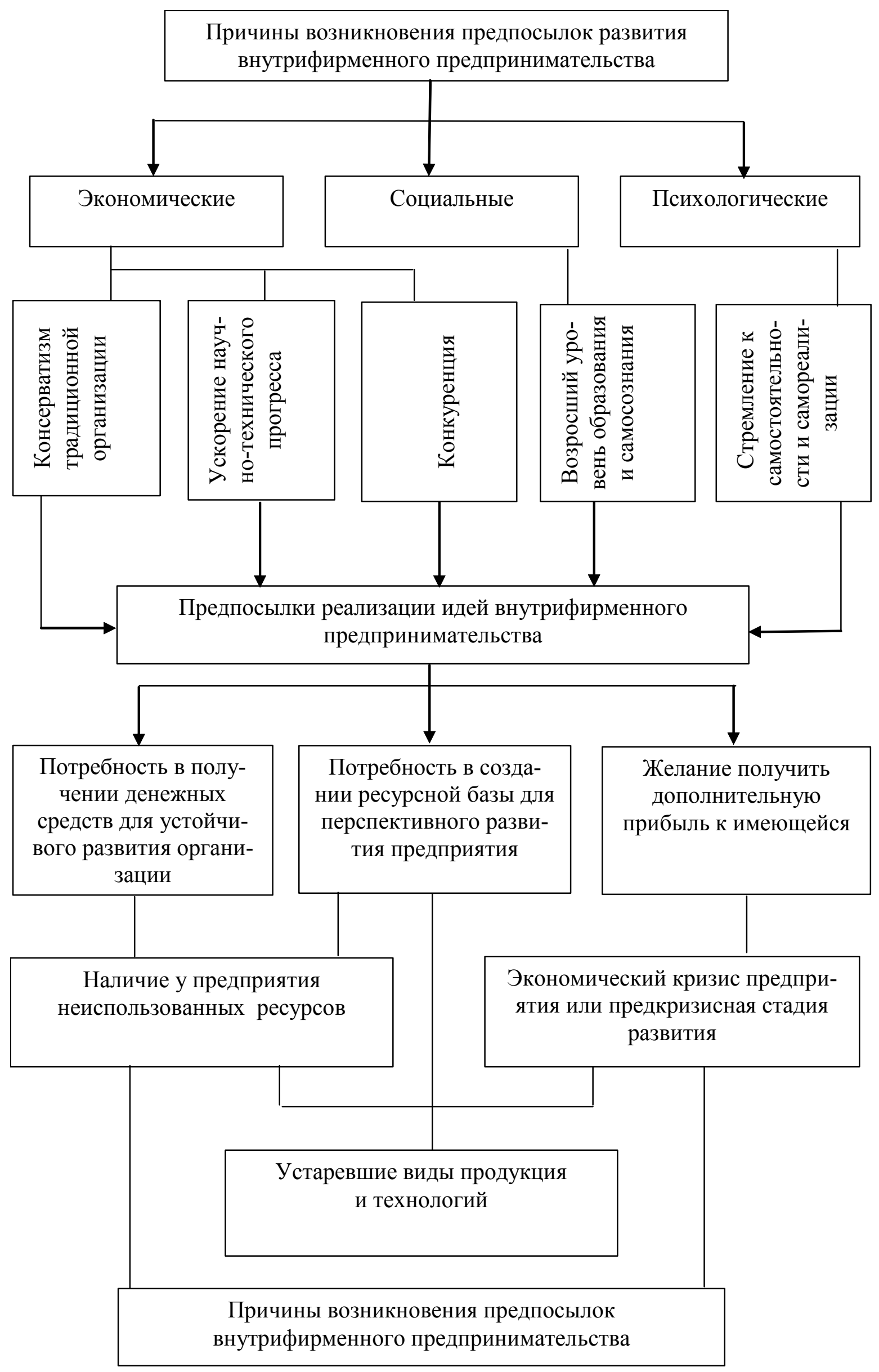

Рисунок 2.7 -. Цели внутрифирменного предпринимательства 
Для развития внутрифирменного предпринимательства в действующей организации традиционного типа ${ }^{1}$ необходимо обеспечить дух предпринимательства и механизм реализации его возможностей, мероприятий, создающих условия для предпринимательской деятельности.

В задачи интрапренера может входить:

1. Реализация возможностей улучшения продукции (работ, услуг), сдвигая таким образом кривые спроса;

2. Поиск новых методов организации производства и новых технологий, сдвигая кривые затрат.

Разработка совершенно новых видов продукции (работ, услуг), создавая новые рынки, характеризующиеся совершенно новыми кривыми спроса и предложения.

То есть одной из главных задач развития внутрифирменного предпринимательства является создание ситуаций, максимально развивающих творческую активность и реализация новаторских способностей.

При этом необходимо учитывать данные исследований в области оценки человеческих способностей с точки зрения потенциальных созидателей (в частности интрапренеров).

Так в результате американских исследований было выявлено, что только $1 \%$ людей одарены «исключительной творческой потенцией» т.е. тем типом который связывается с выдающимися достижениями в том числе в области внутрифирменного предпринимательства. 10\% по шкале Ричарда и Киннея обладают «Высокой» творческой потенцией, $60 \%$ - «умеренной» и «некоторой» творческой потенцией. Около $30 \%$ людей не проявляют творческой активности или делают это в малой степени.

Поэтому, для обеспечения успеха интрапренера необходимо знать его возможности в решении актуальных задач, стоящих перед организацией, и создавать комплекс условий по реализации этих возможностей. Интрапренеру в свою очередь необходимо определить следует ли ему устанавливать партнерские отношения с коммерческой организацией или лучше вести частную предпринимательскую деятельность. Интрапренер должен обладать определенными личностными качествами (рис. 2.8).

1 Организация традиционного типа - работающая в устойчивом режиме, в установившихся управленческих и организационно-производственных структурах и консервативно относящаяся ко всем возможным изменениям. 


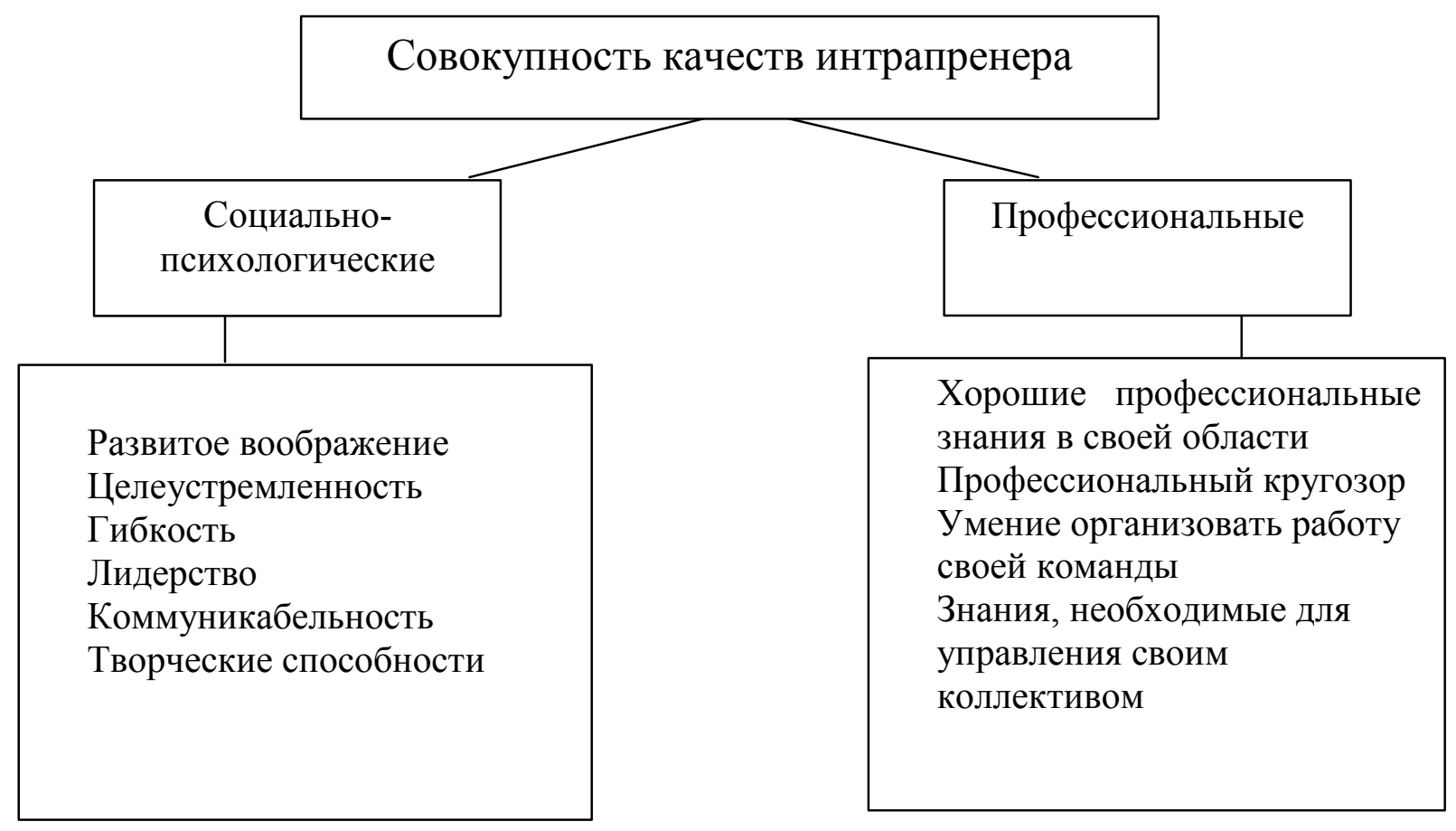

Рисунок 2.8 -. Требования к качествам интрапренера

На всех стадиях предпринимательской деятельности происходит совершенствование элементов внутрифирменного предпринимательства (рис. 2.9). Главным элементом внутрифирменного предпринимательства является дух предпринимательства, являющейся отличительной характеристикой состояния людей, идущих по пути внедрения рисковых проектов.

На уровне предпринимательской организации дух предпринимательства является тем необходимым климатом и настроем сотрудников, которым должна пропитаться вся организация для достижения успеха внутрифирменного предпринимательства. 


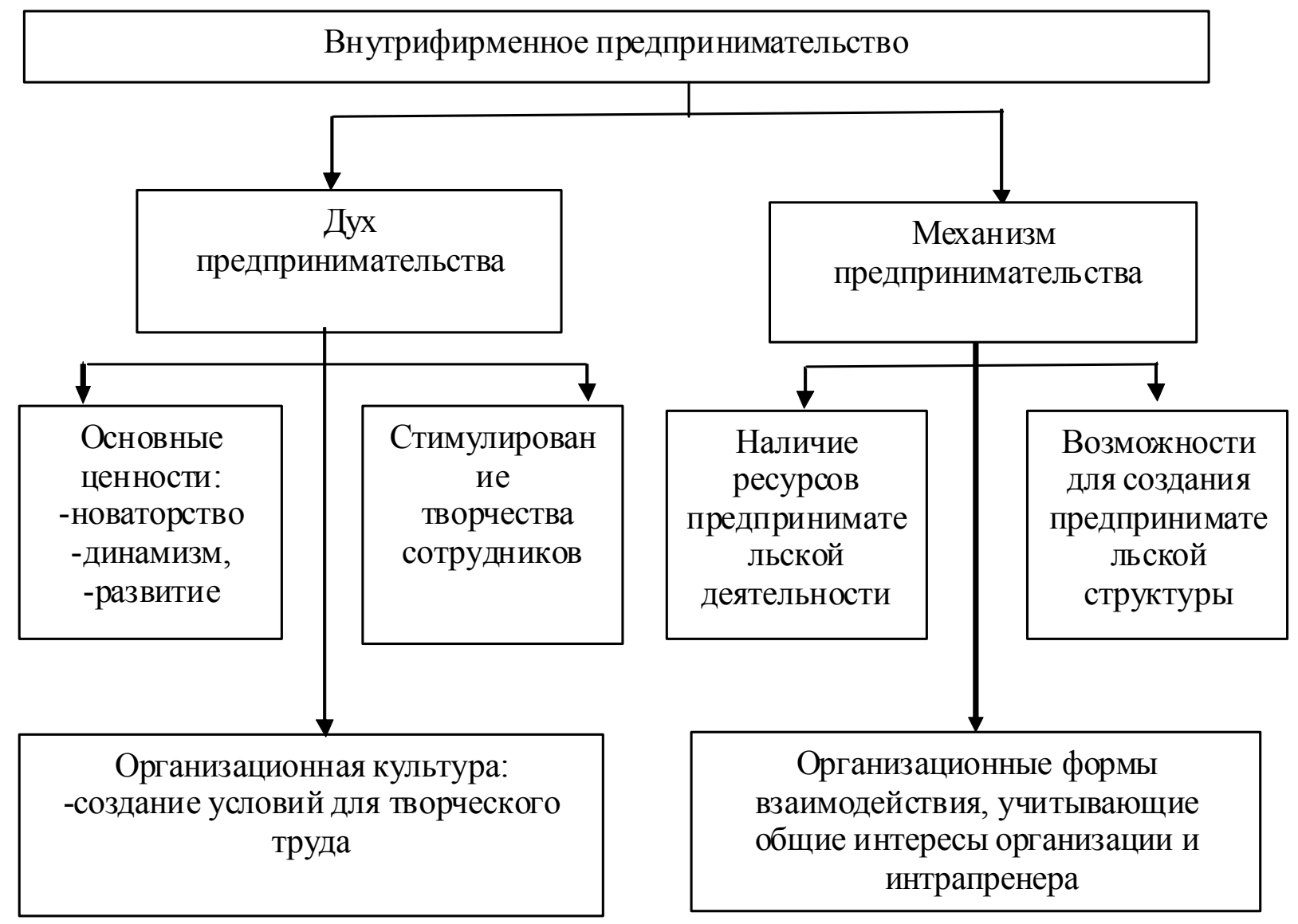

Рисунок 2.9 -. Элементы внутрифирменного предпринимательства

При реализации внутрифирменного предпринимательства каждый работник имеет свою часть обязанностей, за которые он отвечает, в то же время каждый зависит от остальных в деле достижения наилучших результатов.

Поскольку предпринимательская организация должна осуществлять множество действий, а все они носят различный характер, постольку внутри организации также должен использоваться принцип разделения функций по внутрифирменному предпринимательству, то на основе этого разделения устанавливается специализация интрапренеров и группирование остальных работников в фирме в соответствии с различными направлениями внутрифирменного предпринимательства и их стадиями.

Структура внутрифирменного предпринимательства определяется путем разработки целостной схемы производительного процесса в рамках предпринимательской организации, который включает в себя полный набор направлений интрапренерства, без реализации которых невозможно эффективное достижение целей предпринимательской организации.

Развитие внутрифирменного предпринимательства в организации предполагает выделение таких ориентиров, как новаторство и динамизм.

Новаторство - базовая характеристика при описании предпринимателя, но проявляться она может в разных формах. Новаторский дух проявляется в форме находки. Чаще всего такая находка связана с профилем деятельности предприни- 
мательской организации. Новаторский дух может затрагивать различные стороны деятельности организации: от обновления продукции до изменения управленческой политики. При реализации внутрифирменного предпринимательства незаменимым является такое качество человека, как способность к мобилизации (динамизм деятельности), под которой понимается способность приведения всех имеющихся возможностей в активное состояние, т.е. в состояние готовности к действиям.

Мобилизационные (или организаторские) способности, включают умение: сконцентрироваться на какой-то идее, действии или событии;

мобилизовать необходимые ресурсы в нужных форме, качестве и количестве;

мобилизовать существующие связи, контакты, отношения.

Способность к мобилизации является результатом комбинации природной предрасположенности и приобретенного профессионального опыта.

Указанные элементы подводят к еще одной характеристике на основе новаторства и динамизма, а именно - развитию, когда мобилизация внутренних способностей и качеств приводит к новому состоянию интрапренера, способствующему рождению предпринимательской идеи.

Поскольку внутрифирменное предпринимательство («интрапренерство») трактуется как активность по развитию предпринимательской деятельности внутри большой корпорации, то и механизм интрапренерства должен не только создавать возможности для творческого поиска, включать соответствующее вознаграждение для интрапренеров, всемерно стимулировать их деятельность и обеспечивать защиту от бюрократических препон внутри фирмы. Что касается вознаграждения за идеи внутрифирменного предпринимательства, то соответствующим вознаграждением для работников может стать новая занимаемая им должность после удачной реализации предпринимательской идеи и соответственно возросший личный доход.

В таких организациях мотивация работников на творческое сотрудничество, будет одной из главных задач что не ведет к достижению целей внутрифирменного предпринимательства.

Создание условий для "включения" творческой энергии работников - сильный стимулирующий фактор поиска талантливых сотрудников внутри предпринимательской организации. Поэтому необходимо осознанное отношение менеджеров к творческому капиталу предпринимательской организации, представленному ее работникам.

Доминирующей тенденцией мотивации является развитие сильных сторон персонала, когда недостатки будут просто перекрываться возрастающими достоинствами. Необходимо постоянно диагностировать сильные качества людей, всячески их развивать и стимулировать эффективное применение, т.к. талантливый работник требует творческой работы.

Исследуя элементы внутрифирменного предпринимательства, можно сказать, что все они направлены на выявление и развитие в сотрудниках организации необходимых творческих навыков, способствующих реализации собственных идей производства и реализации продукции. 
Этапы взаимодействия интрапренера и организации предпринимательского типа представлены табл. 2.1.

Таблица 2.1

Этапы взаимодействия интрапренера и организации предпринимательского типа

\begin{tabular}{|c|c|c|}
\hline Интрапренер & Характер связи & $\begin{array}{l}\text { Организаиия пред- } \\
\text { принимательского } \\
\text { типа }\end{array}$ \\
\hline \multicolumn{3}{|c|}{ Зарождение предпринимательской идеи (ПИ) } \\
\hline \multicolumn{3}{|c|}{\begin{tabular}{l|l|l} 
1. Формирование ПИ & . \\
\end{tabular}} \\
\hline & & $\begin{array}{c}\text { 2. Определение по- } \\
\text { тенциала организа- } \\
\text { ции для реализации } \\
\text { ПИ }\end{array}$ \\
\hline \multicolumn{3}{|c|}{ Реализация ПИ } \\
\hline $\begin{array}{l}\text { 3. Разработка пугей эффек- } \\
\text { тивного использования ре- } \\
\text { сурсов для реализации ПИ }\end{array}$ & партнерство & $\begin{array}{c}\text { 3. Предоставление } \\
\text { необходимых ресур- } \\
\text { сов для реализации } \\
\text { ПИ } \\
\end{array}$ \\
\hline \multicolumn{3}{|c|}{ Функционирование ПИ } \\
\hline $\begin{array}{l}\text { 4. Контроль за функциониро- } \\
\text { ванием ПИ }\end{array}$ & партнерство & $\begin{array}{l}\text { 4. Получение прибы- } \\
\text { ли от реализации ПИ }\end{array}$ \\
\hline $\begin{array}{c}\text { 5. Получение вознагражде- } \\
\text { ния за реализацию ПИ по } \\
\text { итогам функционирования }\end{array}$ & & \\
\hline \multicolumn{3}{|c|}{ Завершающая стадия функционирования ПИ } \\
\hline $\begin{array}{c}\text { 6. Формирование новой ПИ в } \\
\text { случае решения о диверси- } \\
\text { фикации }\end{array}$ & 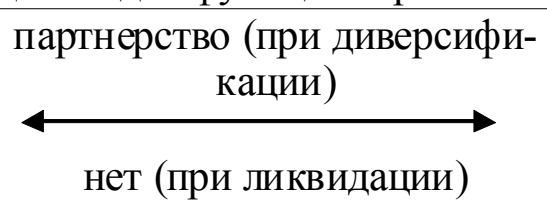 & $\begin{array}{l}\text { 6. Диверсификация } \\
\text { или ликвидация ПИ }\end{array}$ \\
\hline
\end{tabular}

В соответствии с основными фазами становления внутрифирменного предпринимательства весь процесс по совершенствованию предпринимательской организации состоит из следующих стадий:

анализ предпосылок для развития внутрифирменного предпринимательства; создание условий для формирования внутрифирменного предпринимательства;

создание структуры внутрифирменного предпринимательства;

формирование системы взаимосвязи и взаимодействия партнеров в рамках внутрифирменного предпринимательства.

Традиционные компании имеют, как правило, жесткую иерархическую структуру управления. В предпринимательских организациях где развито интрапренерство горизонтальная гибкая разветвленная структура позволяет экспериментировать, внедрять новые идеи, что ведет к эффективному сочетанию общих целей организации и интрапренера. Основные различия организаций традиционного предпринимательского типа представлены в табл. 2.2. 
Таблица 2.2 Сравнение организации традиционного типа о организаций предпринимательского типа

\begin{tabular}{|c|c|c|}
\hline \multirow{2}{*}{$\begin{array}{l}\text { Элементы } \\
\text { Сравнения }\end{array}$} & \multicolumn{2}{|c|}{ Характеристика организаций } \\
\hline & Традиционные организации & Организации- интрапренеры \\
\hline Ценности и цели & $\begin{array}{c}\text { Консерватизм, сохранение ста- } \\
\text { бильности }\end{array}$ & $\begin{array}{c}\text { Новаторство, поиск новых воз- } \\
\text { можностей }\end{array}$ \\
\hline $\begin{array}{l}\text { Основные моти- } \\
\text { вации руково- } \\
\text { дства персоналом }\end{array}$ & $\begin{array}{c}\text { Власть, сохранение работы, } \\
\text { вознаграждение за рутинный } \\
\text { труд, четкая перспектива }\end{array}$ & $\begin{array}{c}\text { Самовыражение, творчество, } \\
\text { стремление к богатству через } \\
\text { новаторскую деятельность }\end{array}$ \\
\hline $\begin{array}{c}\text { Система управле- } \\
\text { ния }\end{array}$ & $\begin{array}{c}\text { Иерархическая, жестко струк- } \\
\text { турированная, многоступенча- } \\
\text { тая }\end{array}$ & $\begin{array}{c}\text { Разветвленная горизонтальная, } \\
\text { линейная, матричная, способст- } \\
\text { вующая взаимодействию от- } \\
\text { дельных подразделений }\end{array}$ \\
\hline Стиль управления & Авторитарный & Демократический, либеральный \\
\hline $\begin{array}{c}\text { Взаимоотношения } \\
\text { персонала }\end{array}$ & $\begin{array}{c}\text { На основе конкуренции и со- } \\
\text { перничества }\end{array}$ & $\begin{array}{c}\text { На основе взаимодействия и } \\
\text { взаимопомощи для достижения } \\
\text { общих целей }\end{array}$ \\
\hline $\begin{array}{l}\text { Характер плани- } \\
\text { рования карьеры }\end{array}$ & $\begin{array}{c}\text { Долгосрочное продвижение по } \\
\text { служебной лестнице }\end{array}$ & Достижение успеха и высоких \\
\hline
\end{tabular}

Следует заметить, что как, и любое другое явление, интрапренерство имеет положительные и отрицательные качества (табл. 2.3)1.

Таким образом, сущность внутрифирменного предпринимательства можно характеризовать с двух точек зрения:

с точки зрения предпринимательской организации - как метод управления в организации, в основе которого заложена инициатива исполнителей, а не администрирование. При этом необходимо учитывать, что высшее руководство предпринимательской организации все же оставляет за собой функции контроля;

с точки зрения субъекта реализации - как форма экономической активности интрапренера.

Итак:

1. Интрапренерство является не только одной из форм развития предпринимательства, расширяющих сферу его возможностей, но и ситуационным фактором, который задается предпринимателем (руководителем предпринимательской организации) исходя из анализа внешней среды и используется для определения граничных условий функционирования предпринимательской организации.

2. Под интрапренерством следует понимать деятельность предприятия по достижению своих целей на основе использования возможностей предпринимательства внутри фирмы.

1 Томилов В.В., Крупанин Т.Д. Маркетинг и интрапренерство в системе предпринимательства: Учеб. пособие /СПб, СПбГУЭФ, 1998. 
Таблица 2.3

Сравнительные характеристики внутрифирменного предпринимательства

\begin{tabular}{|c|c|c|c|c|}
\hline \multirow[b]{2}{*}{$\Pi / \Pi$} & \multicolumn{2}{|c|}{ Интрапренерство } & \multicolumn{2}{|c|}{$\begin{array}{c}\text { Индивидуальное } \\
\text { предпринимательство }\end{array}$} \\
\hline & Достоинства & Недостатки & Достоинства & Недостатки \\
\hline 1 & 2 & 3 & 4 & 5 \\
\hline 1. & $\begin{array}{c}\text { Доступность } \\
\text { финансов } \\
\text { предприятия - } \\
\text { партнера }\end{array}$ & $\begin{array}{c}\text { Бюрократизация, рутин- } \\
\text { ный характер деятель- } \\
\text { ности, затрудняющий } \\
\text { принятие и возникно- } \\
\text { вение предпринима- } \\
\text { тельской идеи }\end{array}$ & $\begin{array}{l}\text { Полная свобода в } \\
\text { своих действиях }\end{array}$ & $\begin{array}{c}\text { Недостаток финансо- } \\
\text { вых и прочих } \\
\text { ресурсов для реализа- } \\
\text { ции предпринима- } \\
\text { тельской идеи }\end{array}$ \\
\hline 2. & $\begin{array}{c}\text { Организационно - } \\
\text { технологическая } \\
\text { помощь при реа- } \\
\text { лизации предпри- } \\
\text { нимательской идеи }\end{array}$ & $\begin{array}{c}\text { Ограничение пред- } \\
\text { принимательской дея- } \\
\text { тельности } \\
\text { интрапренера } \\
\text { принятыми } \\
\text { организацией - учреди- } \\
\text { телем рамками }\end{array}$ & $\begin{array}{l}\text { Повышенная } \\
\text { мотивировка }\end{array}$ & $\begin{array}{c}\text { Сложности технологи- } \\
\text { ческие, организацио-- } \\
\text { ные }\end{array}$ \\
\hline 3. & $\begin{array}{c}\text { Возможность } \\
\text { получения } \\
\text { помощи в форс- } \\
\text { мажорных } \\
\text { обстоятельствах }\end{array}$ & $\begin{array}{c}\text { Необходимость перво- } \\
\text { очередного учета инте- } \\
\text { ресов предприятия - } \\
\text { учредителя }\end{array}$ & $\begin{array}{c}\text { Максимальная моби- } \\
\text { лизация своих сил и } \\
\text { средств для решения } \\
\text { поставленной задачи }\end{array}$ & $\begin{array}{c}\text { Не на кого } \\
\text { рассчитывать при по- } \\
\text { явлении } \\
\text { форсмажорных } \\
\text { обстоятельств }\end{array}$ \\
\hline 4. & $\begin{array}{c}\text { Возможности } \\
\text { использования } \\
\text { предпринима- } \\
\text { тельской струк- } \\
\text { турной системы } \\
\text { продвижения и } \\
\text { сбыта предприятия } \\
\text { - учредителя }\end{array}$ & $\begin{array}{c}\text { Погоня } \\
\text { предприятия-учредителя } \\
\text { за краткосрочными ус- } \\
\text { пехами }\end{array}$ & - & - \\
\hline 5. & $\begin{array}{c}\text { Возможности } \\
\text { использования } \\
\text { опыта, деловой } \\
\text { хватки, } \\
\text { маркетинга и т.д. }\end{array}$ & 一 & - & - \\
\hline
\end{tabular}

3. В основе интрапренерства лежат: создание условий для предпринимательской деятельности, стимулирование и реализация предпринимательских возможностей сотрудников на основе использования ресурсов и организационнопроизводственных возможностей предпринимательской организации.

4. Внутрифирменное предпринимательство одновременно характеризуется как элементами духа, так и механизма предпринимательства, которое при наличии соответствующих ресурсов и организационных форм взаимодействия реализуется посредством таких ценностей как новаторство, динамизм и развитие. 


\section{ГЛАВА 3 \\ ФОРМИРОВАНИЕ И РАЗВИТИЕ ПРЕДПРИНИМАТЕЛЬСКИХ СЕТЕЙ}

\section{1. Сетевые формы объединения организаций (кластеры, предпринима- тельские сети)}

За последнее десятилетие в поведении и сознании граждан государств СНГ состоялись и продолжают происходить значительные изменения. Они вызваны, прежде всего, переходом к другой системе развития общества, построенной на внедрении рыночных отношений и активизации предпринимательской деятельности. При этом важными становятся отношения и поведение людей на разных уровнях их участия в предпринимательской деятельности: между предпринимателями и наемными работниками, предпринимателями и государственными органами, предпринимателями и высшими учебными заведениями и т.п.

Объединение усилий предпринимателей, органов управления, субъектов инвестиционной и инновационной деятельности на определенной территории дает значительные преимущества в конкурентной борьбе и рационализации производственно-рыночных процессов. Такое объединение усилий в некоторых странах оказалось достаточно эффективным с точки зрения реализации программ экономического развития регионов, а иногда и национальных систем.

Объединение участников бизнес-среды базируется на положениях сетевого подхода, получившего широкое распространение в международной хозяйственной практике последних десятилетий. Сетевой подход реализует концепцию взаимодействия, которая опирается на ряд ключевых признаков, свойственных современному предпринимательству:

- схожесть целевых ориентиров реально функционирующих бизнессубъектов (например: обеспечение конкурентных преимуществ, оптимального использования ресурсов, укрепление рыночных позиций и т.п.);

- необходимость использования мер государственной поддержки;

- необходимость привлечения инвестиций в условиях развивающихся рынков (к числу которых относится, в частности, сфера капитального строительства);

- необходимость активизации инновационных возможностей предпринимательства;

- развитие информационно-коммуникационных технологий;

- стремление к получению синергетического эффекта;

- развитие концепции бенчмаркинга, ориентирующую предпринимательские структуры на изучение и конструктивное использование опыта, накопленного лидерами бизнес-сферы;

- развитие идеологии и партнерства.

Спецификой сетевого подхода (в рамках более общего системного подхода) является интеграция отраслевых и территориальных аспектов, возможность более 
полного использования инфраструктурного потенциала, а также способность к изменению конфигурации сети: замене элементов, присоединению дополнительных элементов.

Объединение организаций в единую сеть осуществляется на основе вертикальных и горизонтальных взаимодействий между различными бизнессубъектами и их симбиозной взаимозависимости, определяемой принципом синергизма. Такие объединения позволяют малым и средним организациям комбинировать преимущества малых форм предпринимательства и крупных производств.

Одной из разновидностей современных сетевых объединений являются предпринимательские сети (ПС). Предпринимательскую сеть можно идентифицировать как группу фирм-участников того или иного рынка, объединившихся с целью эффективного использования ресурсов и специфических преимуществ для совместной реализации предпринимательских проектов. Используя преимущественно горизонтальные связи и механизмы специализации и взаимодополнения они получают дополнительные возможности к достижению более высоких результатов.

Предпринимательская сеть объединяет совокупность сетевых партнеров. Cemевые партнеры - это организации, которые формируют предпринимательскую стратегию на основе положений сетевого подхода и в соответствии с принципами функционирования предпринимательских сетей, участниками которых они являются.

Предпринимательскую сеть (как и любое другое сетевое образование) характеризует:

- наличие единой цели;

- наличие четкой внутренней структуры;

- высокая степень взаимосвязи структурных элементов;

- наличие взаимосвязи с внешней средой.

Отличительная черта ПС - предпринимательская целеориентация. ПС всегда направлена на решение задач управления рынком на основе активизации предпринимательских инициатив, гибкости, стратегической маневренности и перманентности инноваций.

В совокупности известных сетевых образований выделяются кластерные модели. Кластеры представляют собой объединения бизнес-субъектов, функционирующих в пределах четко очерченных территориальных образований.

Кластеры можно рассматривать как одну из разновидностей крупных сетей предпринимательского типа. Они представляют собой сеть, охватывающую широкий спектр социально-экономических аспектов. Являясь следствием территориально-отраслевого деления общественного воспроизводства кластеры реально воплощают идеологию сетевого подхода.

Предпринимательские сети отнюдь не всегда столь масштабны. Они могут объединять представителей малого и среднего бизнеса, интегрировать деятельность малых предприятий различного профиля в сферу деятельности представителей крупного бизнеса.

Предпринимательские сети не подвержены жесткой привязке к территори- 
альным параметрам могут иметь локальный характер, а "подвижность" их масштабов позволяет обеспечивать большую гибкость, адаптивность и мобильность предпринимательской деятельности.

Кластеры, в сравнении с предпринимательскими сетями, объединяют значительно широкий круг участников, в том числе институты поддержки, производственные и коммерческие структуры, среди которых производители, поставщики, а также высшие учебные заведения и научные организации. Они агрегируют принципы, как отраслевого, так и регионального (межотраслевого) объединения участников, основанного на вертикальных взаимоотношениях между разнородными фирмами и на взаимодействии инновационных процессов с быстроменяющимся характером рыночных отношений.

Имущественные связи играют весьма существенную роль при объединении, однако, предпринимательские структуры могут группироваться и без опоры на эти связи. Это так называемая форма поддержки предпринимательства в форме индустриальных сетей (производственных сетей, производственных сетевых организаций, предпринимательских сетей) ${ }^{1}$. ПС сочетает элементы рынка и иерархической координации действий, но на первый план в ней выходят кооперационные и информационные связи, а имущественные связи могут присутствовать в форме долевого участия.

Входящие в ПС предпринимательские структуры сохраняют свою автономность, но используют механизмы через вхождения:

- активизируется появление новых управленческих идей и решений;

- ослабляется сдерживающее влияние межорганизационной и внутрифирменной субординации на реализацию этих идей и формирование необходимых связей.

Предпринимательские сети формируются преимущественно на основе динамики структуры рынков, интенсивной по-сути. Кластеры - отражают региональные, межрегиональные, национальные, а в ряде случаев и межнациональные процессы, и являются следствием распределения производительных сил. Однако опыт, накопленный отечественной и зарубежной управленческой практикой в области использования кластерной концепции, может быть успешно применен при формировании сетей любого уровня, в том числе и предпринимательских сетей, функционирующих в инвестиционно-строительном комплексе.

Результаты создания новых производственных систем на основе сетевых структур - кластеров стал темой Первого Всемирного конгресса в Париже (Январь 2001г.) проведенного по инициативе Организации сотрудничества и развития (OECD) и рядом других организаций (LEED, DATAR, UNIDO и др.).

Центральной Европейской Инициативой (C.E.I.) разработаны принципы кластеризации для 5 стран Вышеградской группы, в которую входят Венгрия, Поль-

${ }^{1}$ Асаул А.Н., Денисова И.В. Интеграция строительных фирм в форме сетевых индустриальных организаций//Регион: политика, экономика, социология. 2001. № 1. С. 61-64; Асаул А.Н. Сетевые индустриальные организации как форма концентрации производства// "Світовий та вітчизняний досвід запровадження нових виробничих систем (кластерів) для забезпечения економічного розвитку територій": Сб. материалов конф. Союза экономистов Украины Киев, 2001 C.40-48. 
ша, Словакия, Словения и Чехия.

C.Е.I. выявляет основные проблемы и препятствия на пути кластеризации и определяет специальные аспекты кластерного анализа, с тем, чтобы вырабатывать свод стратегических рекомендаций, применимых для регионов. С.Е.І. содействует развитию сотрудничества между местными и региональными партнерами, между частными и государственными структурами проводит исследования кластеров, определяет перспективы их развития и решает, связанные с ними проблемы. Над программами кластеризации в регионах ведется работа, по обеспечению синхронизации со всеми странами Европейского Союза.

Решение этих задач позволяет составить карту кластеров, которые далее должны исследоваться совместно группами местных экспертов и специалистами в рамках утвержденной программы развития кластеризации в странах Вышеградской группы.

В основе кластерной концепции C.Е.I. положены эффект регионализации, необходимость унификации экономического и технического инструментария, а также целесообразность их дифференциации в силу характера и специфики отдельных стран (групп стран, регионов).

Страны Вышеградской группы переориентировали свою государственную политику в сторону европейского рынка и являются наиболее последовательными в реализации кластеризации. Эти страны имеют наиболее благоприятные показатели в сравнении с другими странами с переходной экономикой в области иностранных инвестиций и погашении инфляции. Из всех 27 восточноевропейских стран с переходной экономикой Вышеградская группа за 11 последних лет реформ сумела превзойти уровень ВНП, который она имела до начала трансформации, и этому в немалой степени способствовало внедрение новых производственных систем - кластеров, которые за последние два десятилетия получили широкое распространение не только в странах Европейского союза (Австрия, Италия, Финляндия, Франция,), но и в Европейских странах с переходной экономикой, так называемой "Новой Европы", в развивающихся странах (Индия, Нигерия, Чили, Гана), а также в арабском мире (Марокко, Иордания, Сирия, Ливан, Египет, Саудовская Аравия, Объединенные Арабские Эмираты и др.).

На постсоветском пространстве лидером по реализации мирового опыта создания новых региональных производственных систем на основе кластеров является Украина. Первым шагом внедрения кластерной концепции на Украине была Программа "Подолье Первый", которая начала свою деятельность в Хмельницкой области в середине 1998 г. Программа "Подолье Первый" - это попытка остановить спад производства и повысить производительность промышленности региона Подолье на Украине собственными силами, используя преимущества от кооперации и от объединения усилий без привлечения государственных средств. На сегодня главная цель Программы - возрождение промышленного предпринимательства в трех областях: производства строительных материалов, швейной и переработки сельскохозяйственной продукции.

Объединение ряда малых предприятий в строительный кластер позволило начать собственное производство обширной номенклатуры строительных смесей (шпаклевок, клеев, наливных полов и т.п.). Примечательно, что для организации 
производства было использовано местное оборудование, полученное в лизинг или выкупленное в результате конверсии бывших военных объектов, а также местное сырье (песок, глина, гипс, цемент и т.п.), но были заимствованы и внедрены новые зарубежные технологии производства смесей. Участники строительного кластера нашли собственную оригинальную форму взаимоотношений, позволяющую аккумулировать средства и ресурсы (финансовые, производственные, трудовые) для реализации масштабных предпринимательских проектов, например, строительства многоквартирных домов по заказам населения.

Создание и продвижение распространения кластерной модели в регионе Подолья и во всей Украине обеспечивает созданная в 1998 г. общественная организация - Ассоциация "Подолье Первый", в руководящий комитет которой вошли известные в регионе представители власти, руководители банков, учебных заведений, предпринимательских структур, в том числе и директоры кластеров, инновационных фондов, торгово-промышленной палаты и других организаций.

Для эффективной работы кластеров необходимо их тесное сотрудничество с научными учреждениями и органами местной власти. В руководящий комитет Ассоциации входят ведущие ученые Технологического университета Подолья, руководители управлений экономикой областной администрации, председатели городских и сельских советов. Организации, которые входят в кластеры Ассоциации "Подолье Первый" получают такие преимущества, как доступ к помощи экспертов по технологической модернизации производства, по вопросам внедрения торговых знаков и экспортных стандартов, новейших технологий и маркетинга, участие в промышленных выставках, ярмарках, программе стандартизации.

В Соединенных Штатах организации, подобные Ассоциации "Подолье Первый", являются связующим звеном и часто определяют подходы и системы сотрудничества между предпринимательскими структурами и властью. Они, как правило, выполняют такие функции:

- обеспечивают постоянные коммуникации правительства, предпринимательства и общественности;

- являются нейтральным субъектом экономической и общественной политики, где формируются новые идеи относительно путей улучшения экономической среды и повышения жизненного уровня населения;

- выступают как катализатор и посредник в создании и поддержке инициатив относительно последовательных изменении в экономике и гражданском обществе.

Появление Ассоциации "Подолье Первый" в Украине пришлось на время изменений в социально-экономических условиях как государства в целом, так и в отдельных его регионах. В настоящее время Ассоциация является активным двигателем преобразований относительно изменения взаимоотношений между предпринимателями и властью, сотрудничества научных учреждений и предпринимательских структур, уменьшения недоверия между организациями-конкурентами в одной области промышленности и особенно на одной территории, стимулирования внедрения инноваций, поиска инвестиций, технической и консультативной поддержки перспективных проектов.

Таким образом, кластеры следует рассматривать как новый способ агрегиро- 
ванного использования преимуществ отраслевого расположения организаций и возможностей регионального управления. Кластеры ориентированы на экономический успех территории, на которой они расположены и, как и органы власти, которым поручено управление регионом или государством, могут обеспечить его экономическое развитие, привлечение дополнительных инвестиций, активизацию инновационных процессов, а также решение многих социальных проблем.

Сущность понятия "кластер"1 состоит в объединении отдельных элементов (составных частиц) в единое целое для выполнения определенной функции или реализации определенной цели. Это же значение вкладывается и в экономическое содержание этого слова. Так, американский ученый Майкл Портер, специалист в области кластеров, дает следующее определение: "Kластеры - это сосредоточение в географическом регионе взаимосвязанных организаций и учреждений в границах отдельной области"2. Кластеры охватывают значительное количество разного рода предпринимательских структур, важных для конкурентной борьбы, а именно: поставщиков специального оснащения, новых технологий, услуг, инфраструктуры, сырья, дополнительных продуктов и т.П.. Кроме того, "...много кластеров включают органы власти и прочие учреждения - такие, как университеты, центры стандартизации, торговые ассоциации, которые обеспечивают образование, специализированное переобучение, информацию, исследования и техническую поддержку".

Подобное определение кластеров, дает Лоурен Э. Янг, который пишет: "Кластеры фирм - это группы компаний, расположенных рядом. В отдельных случаях такие сосредоточения образовывают группы компаний, которые принадлежат к одной и той же отрасли". К общим характерным признакам кластеров, кроме тех, что названы в определении, Лоурен Янг относит также расположение вблизи больших исследовательских университетов; образование преимущественно из небольших частных компаний; наличие опыта работы их работников во многих разных организациях соответствующей отрасли. ${ }^{3}$

Еще один американец, Вольфганг Прайс пишет: "Создание кластеров и внедрения кластерной модели поведения организаций есть способ восстановления доверия между правительством и бизнесом и трансформации изолированных фирм в предпринимательское сообщество". ${ }^{4}$

Таким образом, кластер - это группа близких, географически взаимосвязанных компаний и сотрудничающих с ними организаций, совместно участвующих в предпринимательской деятельности, характеризующихся общностью направлений этой деятельности и дополняющих друг друга. Они создают основу для притока иностранных инвестиций, обучения широкого круга предпринимателей, развития малого и среднего предпринимательства, повышения гибкости и мобильно-

${ }^{1} \mathrm{C}$ английского языка слово "claster" переводится как гроздь, букет, щетка, или как группа сосредоточение (например, людей, предметов), или как пчелиный рой.

${ }^{2}$ Портер М. Конкуренция. - М.: Изд. дом "Вильяме"; 2000. - 495 с.

${ }^{3}$ Соколенко С.И. Производственные системы глобализации: Сети. Альянсы. Партнерство. Кластеры: Укр.Контекст. - Киев: Логос, 2002.

${ }^{4}$ Войнаренко М.П. Кластерные технологии в системе развития предпринимательства, интеграции и привлечения инвестиций. http: www.unece.org/ie/wp8/documents/novsem.htm 
сти компаний, создания широкого спектра ПС. Одновременно кластеры выступают и как форум, в рамках которого ведется диалог между деловыми, правительственными и научными кругами о путях развития конкурентных преимуществ в рамках города, страны ${ }^{1}$.

Характерными особенностями успешной деятельности кластеров, как правило, могут быть:

- взаимосвязи, которые позволяют участникам кластеров приобретать более мощный производственно-рыночный потенциал в сравнении с теми организациями, которые работают поодиночке;

- кооперация и сотрудничество, которые являются стимулами к поиску новых, более совершенных предпринимательских идей и решений;

- ориентация на потребности рынка, которая является главным фактором определения стратегии предпринимательства;

- обеспечение соответствия стратегии каждого отдельного вида предпринимательской деятельности общей стратегии развития региона.

Возникновение и развитие кластерной модели поддержки регионального развития отдельных отраслей промышленности имеет долгую историю. Примеры эффективности функционирования отдельных кластеров свидетельствуют о перспективности использования такой модели для объединения предпринимательских структур в разных областях и регионах. В особенности эффективными и своевременными они могут оказаться для' отечественных организаций во времена выхода из ситуаций экономического кризиса. Внедрение данной концепции возможно на любой территории и в любой отрасли. А достижение успеха базируется на целом ряде преимуществ, которые получают разрозненно действующие организации, объединяясь в кластер. ${ }^{2}$

Кластер, объединяя независимые и неформально связанные компании и учреждения, представляет собой организационную форму, которая получает значительное количество преимуществ за счет высокой производительности, эффективности и гибкости в процессе организации предпринимательской деятельности.

Объединяя в себе одновременно и конкуренцию и сотрудничество, кластеры имеют значительные преимущества в конкурентной борьбе. Ведь современная конкуренция зависит, прежде всего, от производительности и гибкости предпринимательских процессов, а не от географического расположения области, доступа к ресурсам или масштаба организации. Большие и малые предпринимательские структуры могут быть высокопроизводительными в любой области, если они применяют современные методы организации работы, используют передовые технологии и предлагают уникальные продукты. Кластерные модели позволяют во всех областях применять передовые технологии, обеспечивая их высокую технологичность.

В связи с этим, М. Портер делает вывод, что не существует такого понятия, как низкотехнологические области. Есть лишь низкотехнологические организа-

${ }^{1}$ Портер М. Международная конкуренция.-М., 1993.

${ }^{2}$ Подробнее см. Асаул А.Н. Кластерный характер развития регионального инвестиционно-строительного комплекса // Экономика развития региона: проблемы, поиски, перспективы / Ежегодник. Вып.4. Волгоград, Изд-во ВолГУ, 2004. 
ции (не предпринимательского типа), то есть, это те организации, которые не способны использовать новейшие технологии и работать так, чтобы повысить производительность и внедрять инновации.

Кластерная модель объединения организаций предлагает новый способ получения преимуществ от таких факторов как географическое расположение, сотрудничество, специализация, кооперация, инновация и т.п. М. Портер определил возможности увеличения конкурентоспособности организаций, объединяющихся в кластеры по трем направлениям:

1. Кластеры повышают производительность компаний, используя преимущества тех, кто работает в одной географической зоне.

2. Кластеры, направляя свою деятельность на высокотехнологические инновационные проекты, достигают более существенного экономического роста, чем их конкуренты.

3. Кластеры стимулируют создание новых организаций, которые в будущем становятся участниками этих же кластеров и тем самим усиливают их.

Лоурен Янг также выделяет ряд преимуществ отраслевых кластеров, причем, как на уровне отдельных организаций, так и на уровне общества. Так организации, которые объединяются в кластеры, получают преимущества за счет роста в них качества рабочей силы, разного рода исследований и более скорых изменений в технологии. Кроме того, положительный эффект, дает удешевление первичных факторов производства, вследствие более эффективного использования новинок и роста производительности за счет обмена идеями между участниками кластера и широкого выбора (быстрого набора) кадров для организаций с открытыми вакансиями.

Создание и эффективное функционирование кластеров придает дополнительный стимул в решение общественных задач. Возрастают возможности получения работы для большого количества трудоспособного населения, что, в определенной мере, решает проблемы безработицы; усиливается экономическое развитие регионов, которые оказывают содействие созданию и развитию кластеров; происходит совершенствование базы налогообложения за счет привлечения местной власти для лоббирования мероприятий по поддержке развития предпринимательства в регионе.

Специализация и кооперация, которые происходят в кластерах, обеспечивают деление рынка на сегменты и цивилизованную специализацию предпринимательской деятельности, что уменьшает транспортные затраты, обеспечивает рациональное разделение труда, обмен знаниями, технологиями, квалифицированной рабочей силой. ${ }^{1}$

Кластеры, сдерживая внешнюю конкуренцию и ускоряя инновации в предпринимательских структурах, могут удерживать определенную часть рынка через дифференциацию продукции внутри кластера и внутри региона.

Кластеры всегда стараются усовершенствовать свои средства производства, внедрять новейшие технологии, обеспечивать высокие стандарты качества про-

${ }^{1}$ Подробнее см. Асаул А.Н. Методология нобелевских работ и опыт изучения мезоэкономических объединений в регионе // Нобелевские лауреаты по экономике. 
дукции. Эта форма привлекает капиталы и кредиты на выгодных условиях от финансовых учреждений, которые конкурируют в обслуживании процветающих отраслей. Объединение организаций в кластеры открывает более реальные возможности получить инвестиции и для небольших организаций-участников соответствующих объединений.

Членство в общественной организации, которая объединяет кластеры, и в самих кластерах дает возможность получать помощь экспертов-консультантов по вопросам технологической модернизации предпринимательской деятельности; экспертов по внешней торговле относительно внедрения торговых знаков и экспортных стандартов; экспертов юридических учреждений относительно регистрации и оформления соответствующих документов и т.п.

Для участников кластеров расширяется доступ к информации относительно разных аспектов деятельности, открывается возможность создания компьютерного центра и использования Internet для получения информации об имеющихся свободных материальных ресурсах, рынках сбыта, возможностях выхода на зарубежные рынки, налаживанию связей с партнерами по производству, а также получению информации о конкурентах, как на внутреннем, так и внешнем рынках.

Значительные преимущества участникам кластера дает общая закупка и продажа. Общая закупка оснащения, комплектующих, материалов и т.п. ведет к уменьшению цены за счет увеличения объемов закупок. Кроме того, для участников объединения существенно уменьшаются затраты на маркетинговые исследования, рекламу, страхование, внедрение сертификатов качества, участие в промышленных выставках, торговых ярмарках и конференциях, поездках предпринимателей в более развитые страны для изучения передового опыта и т.п.

Открываются возможности общей переподготовки и поиска необходимых (в зависимости от специализации) опытных и квалифицированных рабочих. Уменьшается риск от перемещения (передислокации) рабочих с других организаций в рамках одного кластера, а также снижаются затраты на переобучение.

Важно подчеркнуть, что участники кластеров получают многочисленные преимущества именно от объединения и сотрудничества, не теряя при этом своей самостоятельности.

Развитие малых и средних предприятий на основе использования концепции кластеров требует новых подходов к определению политики поддержки предпринимательства органами власти и их вмешательства в системы его регулирования. Вмешательство должно базироваться на трех принципах.

Во-первых, потребности рынка определяют развитие мощностей, а вмешательство в деятельность и стратегию развития предпринимательской деятельности должны определяться потребностями потребителей.

Во-вторых, политика должна быть нацелена на объединение усилий всех сторонников кластерных объединений, то есть на коллективные действия. Вмешательство должно оказывать содействие развитию связей между организациями, кооперации и специализации, обмену знаниями и т.п.

В-третьих, целью политики должно быть содействие укреплению способности к самодостаточности, выживанию и инновациям в частном предпринимательстве.

Ключевой характеристикой действующих кластеров - параметры рынков, на 
которые они работают. Именно спрос определяет деятельность эффективно работающих кластеров. Выходы на новые рынки, которые имеют высшие требования к продукции, ее качеству и условиям поставок могут быть реальным стимулом к усовершенствованию. Органы власти могут стимулировать такие стратегии путем предоставления субсидий для проведения торговых ярмарок для привлечения покупателей и для организации обмена опытом между местными и зарубежными компаниями.

Характеристика деятельности отдельных отечественных организаций, объединившихся в кластеры и ПС, свидетельствует о пригодности этих концепций для применения на российском рынке. При этом, следует учитывать, что отсутствие стандартизированных правил в области кластеризации приводит к тому, что все исследуемые и формирующиеся кластеры имеют индивидуальный и уникальный характер. Несмотря на общие направления развития и линии поведения в производстве продукции, уникальность каждого региона приводит к разным конечным результатам.

Предпринимательские сети, в общем виде, могут иметь формализованный характер (образовывать самостоятельные организационные формы) и неформализованный. В строительстве эффективно функционирует целый ряд таких сетей.

В качестве примера ПС может служить акционерная производственнопроектная агростроительная корпорация "Нечерноземагропромстрой", деятельность которой распространена на 28 регионов России. При этом характерен факт объединения в самые разнообразные организационные корпоративные формы в соответствии с региональными условиями деятельности':

холдинги - "Дороги России" (Москва);

ассоциации - "Новгородсельстрой", "Архоблстрой", "Удмуртсельстрой" (некоммерческая);

объединения - "Псковагропромстрой", "Чувашагропромстрой", "Калугаагрострой", "Соколовский строительный комплекс" (Рязанская область), "Агростроймонтаж" (Мурманская область), "Калининградагрострой", "Вологдагрострой", "Комижилстрой";

акционерные общества - "Брянскагропромстрой", "Арзамасагрострой", "Ярославльагропромстрой";

государственные предприятия - ГУП "Центральный научноисследовательский, экспериментальный и проектный институт по сельскому строительству" (ЦНИИЭПсельстрой); "Центрэлеваторспецмонтаж" (Московская область);

ПС - "Проектно-строительное объединение "Леноблагрострой".

Основными принципами сетевой интеграции строительных организаций являются:

1. Формирование единого информационного пространства, когда в ПС через взаимодействие головной организации с организациями-участниками вырабатывается новая информация, становящаяся движущей силой деловой активности.

1.1. Генерация и обмен новой информацией:

${ }^{1}$ http://www.napstroi.ru 
- изучение и распространение опыта по созданию и работе фондов развития жилищного строительства с последующим внедрением в организациях, входящих в корпорацию;

- изучение отечественного и зарубежного опыта строительства монолитных, каркасных и каркасно-монолитных домов;

- изучение, обобщение передового опыта внедрения новых технологий, материалов, оборудования и распространение его в организациях и предприятиях корпорации в виде информационных материалов (обзоры, тематические подборки, экспресс-информация), издание и распространение сборников "Новые технологии, оборудование и материалы";

- обеспечение организаций информацией о мерах по снижению стоимости строительства за счет внедрения эффективных технологий, материалов и оборудования;

- доведение до организаций информации о конъюнктуре цен на основные виды отечественных и зарубежных материалов;

- организация семинаров-совещаний, учебных семинаров;

- подготовка информационных справок об опыте работы лучших коллективов.

1.2. Единство финансового пространства:

- проведение зачетов по погашению бюджетной задолженности, что предполагает полную ее ликвидацию по платежам в бюджет;

- проведение взаимозачетов с поставщиками и подрядчиками по заявкам входящих в корпорацию организаций, что приводит к улучшению их финансового положения;

- разработка и защита в Минэкономики РФ, Минфине РФ и Минсельхозпроде РФ бюджетной заявки для финансирования строительства производственной базы организаций, входящих в корпорацию. При этом составляются детальные бизнеспланы и проекты, делаются расчеты и определяется экономическая эффективность вложения средств;

- инвентаризация кредиторской задолженности за выполненные работы на объектах собственной производственной базы в соответствии с перечнем строек на развитие производственных мощностей для жилищного строительства на селе. Экономическая эффективность данной деятельности выражается в полном погашении кредиторской задолженности.

1.3. Единство технологического и строительного пространства:

- работа по сохранению технологического единства сельского строительного комплекса;

- согласование с Минэкономики перечня строек, которые финансируются в определенный год. При этом экономически определяется общая сумма финансирования.

1.4. Единство правового пространства:

- методологическая и консультативная помощь организациям, входящим в ПС, по финансовым вопросам;

- методологическая и консультативная помощь организациям и предприятиям при формировании территориальных фондов индивидуального жилищного строительства. При этом консультации проводятся в объеме, необходимом строитель- 
ным фирмам, входящим в ПС;

- практическая помощь организациям, входящим в корпорацию, в вопросах защиты экономических интересов;

- помощь в получении и продлении лицензии РФ на строительную деятельность;

- консультационные услуги и методическая помощь организациям корпорации в области материально-технического обеспечения;

- методологическая помощь организациям, входящим в корпорацию, по подготовке документов, необходимых для получения централизованных инвестиционных ресурсов и валютных кредитов.

2. Совершенствование строительных процессов. Как известно, отдельная строительная фирма зависит от доступа к ресурсам, контролируемых другими фирмами. Будучи включенной в ПС, эта фирма получает доступ к технологиям, сырьевым материалам, комплектующим и т.д.

2.1. Строительство и внедрение эффективных технологий:

- внедрение в производство конструкций с применением различных теплоизоляционных систем, в том числе системы "РУСХЕК", при строительстве новых, реконструкции и утеплении существующих зданий. При использовании таких конструкций в 2-3 раза снижается материалоемкость и повышается термическое сопротивление стены. Объем внедрения по данному пункту составляет 200 тыс.кв.м фасадов зданий;

- строительство экспериментальных жилых домов с учетом современных архитектурно-планировочных решений, теплозащитных требований с применением современных автономных систем инженерного обустройства (на настоящий момент уже построено 4 таких дома);

- внедрение локальных котельных при строительстве многоквартирных жилых домов (к настоящему моменту объем внедрения составляет 8 котельных). При этом достигается снижение эксплуатационных затрат и повышение конкурентоспособности подобных объектов;

- внедрение системы поквартирного отопления жилых домов;

- организация и совершенствование технологии производства эффективных стеновых и теплоизоляционных материалов на основе пенобетона. На этой базе корпорацией создано 6 предприятий, которые осваивают данную продукцию;

- организация производства новых видов бетонных и железобетонных изделий повышенной сложности методом вибропрессования (труб, колец). Выпуском данного вида конкурентоспособной продукции занимаются 8 предприятий, входящих в ПС "Нечерноземагропромстрой";

- внедрение в производство железобетонных конструкций и строительных растворов высокоэффективных химических добавок типа "Лигнопан" (2 предприятия);

- организация работ по строительству, реконструкции и техническому перевооружению предприятий стройиндустрии с обеспечением ввода в действие мощностей по производству строительных изделий, материалов, конструкций;

- инженерное обустройство сельских поселков и жилых домов.

2.2. Внедрение новых архитектурно-планировочных решений: 
- отбор паспортов проектов жилых домов с учетом новых требований СНиП по теплотехнике и корректировка ранее выпущенных каталогов жилых индивидуальных домов (на основе собранных данных уже составлен каталог паспортов);

- подготовка каталога паспортов проектов крестьянских (фермерских) хозяйств и перерабатывающих предприятий малой мощности.

2.3. Внедрение новейших основных и оборотных фондов строительства:

- внедрение высокоэффективного вибропрессового оборудования, в том числе для изготовления бордюрного камня, мелких стеновых блоков и дорожных элементов мощения. Реализацией данного проекта занимаются 5 предприятий;

- производство высокоэффективных основных видов строительных машин и изготовление новых образцов и партий машин и оборудования. Данное направление, прежде всего, направлено на повышение в организациях производительности труда и снижение затрат на капитальный ремонт строительных машин.

3. Формирование общей коммерческой политики и политики внешнеэкономической деятельности.

3.1. Сбыт и сервисное обслуживание, приобретение необходимых ресурсов:

- участие в реализации продукции организаций, входящих в корпорацию (изучение рынка, налаживание контактов с потенциальными потребителями, увеличение числа организаций-поставщиков и расширение номенклатуры поставляемых изделий и материалов). Экономическая эффективность данных проектов рассчитывается отдельно;

- оказание участникам корпорации практической помощи в реализации готовых квартир и приобретении незавершенных строительством жилых домов для достройки;

- практическое содействие в поставке более дешевых строительных материалов и изделий. Данное обстоятельство приводит к удешевлению строительномонтажных работ и других работ.

3.2. Участие в инвестиционных проектах:

- головная компания стремится к максимальной загрузке, входящих в корпорацию строительных компаний, чему способствуют работа с федеральными министерствами и ведомствами государственного управления по вопросам инвестиционной политики, финансирования государственных и других программ, участие в подрядных торгах на федеральном уровне. В частности, корпорация участвует в реализации президентских программ "Строительство на территории РФ жилья для граждан, выезжающих из районов Крайнего Севера и приравненных к ним местностей", "Государственные жилищные сертификаты", программ "Крестьянский дом", ведет работу с ОАО "Норильская горная компания" ("Норильский никель");

- организация подготовки материалов для участия в конкурсах корпорации и Госстроя РФ, вследствие чего достигается максимальное вовлечение в инвестиционно-строительную деятельность организаций и предприятий, повышается их конкурентоспособность;

- совершенствование работы Фонда развития информации и прогрессивных технологий.

3.3. Внешнеэкономическая деятельность:

- организация совместной деятельности с организациями по структурной пере- 
стройке производства, техническому сопровождению внедрения новых технологий и повышению конкурентоспособности продукции на взаимовыгодных условиях.

4. Повышение профессионального уровня персонала.

4.1. Повышение квалификации руководящего персонала:

- профессиональное лицензирование руководителей;

- организация стажировок руководящего персонала с целью изучения мирового опыта строительства;

- повышение квалификации руководителей, специалистов (на каждый год планируется определенное количество человек);

- организация персональных школ лучших руководителей. Корпорацией уже создано 5 школ на базе передовых организаций, что заметно повысило уровень деловой квалификации в управлении производством.

4.2. Повышение квалификации рабочих:

- организация стажировок рабочего персонала с целью изучения мирового опыта строительства;

- обучение рабочих в учебных комбинатах.

4.3. Стимулирование труда и социальная защита:

- награждение работников предприятий и организаций государственными и ведомственными наградами за высокоэффективный труд;

- проведение реабилитационных мероприятий и оказание лечебной помощи работникам;

- разработка Положения о порядке формирования и расходования Фонда социальной поддержки, направленного на улучшение социальных условий работников организаций, входящих в корпорацию.

Не менее важно наличие в ПС специализированного научнопроизводственного центра, в который привлекаются ученые, научные работники, молодые специалисты.

В состав корпорации "Нечерноземагропромстрой" входит ГУП "Центральный научно-исследовательский, экспериментальный и проектный институт по сельскому строительству" (ЦНИИЭПсельстрой), которое выполняет:

- разработку научно-технических прогнозов в сельском строительстве;

- разработку и участие в выполнении целевых государственных программ различных отраслей АПК;

- исследования и разработку строительных деревянных, металлических, железобетонных и композитных конструкций и изделий для сельского строительства;

- исследования и разработку технологии, оборудования и технологических линий по производству строительных конструкций, изделий;

- исследования и разработку новых видов материалов и изделий, способов и оборудования для их производства;

- оценку теплотехнических качеств эксплуатируемых и проектируемых сельскохозяйственных зданий с разработкой способов повышения их тепловой защиты;

- энергоаудит с разработкой энергосбережения на промышленных, производственных сельскохозяйственных зданиях и гражданских объектах; 
- совершенствование объемно-планировочных и конструктивных решений сельскохозяйственных производственных, общественных и жилых малоэтажных зданий, инженерных сетей и оборудования;

- разработку проектов сельскохозяйственных производственных, общественных и жилых зданий;

- издательскую деятельность;

- подготовку научных кадров через аспирантуру.

В последнее время получают развитие так называемые оболочечные строительные организации, которые строят реализуют конкретную бизнес-идею. В своем арсенале они имеют торговую марку, команду менеджеров и оборотный капитал. Все остальное (от разработки проекта строительства до продажи и сервисного обслуживания) такая организация приобретает у специализированных компаний, входящих в ПС. Именно этой бизнес-модели соответствует "Домостроительная инвестиционная компания" ("Доминко"), которая ввела в 2001 г. 6 тыс. кв. м жилья повышенной комфортности, а в настоящее время занимается реконструкцией здания-памятника и жилых домов в Адмиралтейском районе города.

Результаты деятельности указанных объединений свидетельствуют об их возможности эффективно функционировать в условиях быстро развивающегося инвестиционно-строительного рынка. При этом актуализируются задачи совершенствования систем управления сетевыми структурами в строительстве, а в более общем смысле - и в других отраслях производственно-экономического комплекса. Решению этих задач будет способствовать изучение теоретикометодологических основ формирования и развития предпринимательских сетей, их адаптация к условиям инвестиционно-строительного комплекса, поиск методов и приемов, позволяющих управлять ПС с учетом ключевых положений современного менеджмента и маркетинга, базирующихся на сочетании принципов использования рыночной адаптивности и рационализации ресурсов.

Под воздействием глобализационных процессов в мировой экономике происходят изменения объекта хозяйственного управления ${ }^{1}$. Так, в индустриальном обществе этим объектом управления выступали предприятия и фирмы, включающие несколько предприятий. В постиндустриальном, информационном - основным объектом хозяйственного управления становятся индустриальные, предпринимательские сети, представляющие планомерно организованную на основе долгосрочных контрактов сеть предприятий и организаций, участвующих в проектировании, производстве, реализации (а в жилищно-коммунальном хозяйстве и строительстве и в сервисном обслуживании). В объединениях традиционного типа (холдингах, концернах, трестах и т.д.) организации могут полностью или частично лишиться юридической, хозяйственной самостоятельности и т.д. Подобные объединения имеют, как правило, громоздкую управленческую структуру, что не всегда позволяет им достаточно четко и своевременно реагировать на изменения внешней среды. Кроме того, они имеют тенденцию к монополизации.

${ }^{1}$ Подробнее см.: Асаул А.Н., Белоус А.Б. Состояние экономической теории и методологии в решении проблемы управляемости//Регион: политика, экономика, социология.-СПб., 2002.-С. $3-4^{\prime}$. 
Мировой и отечественный опыт ${ }^{1}$ показывают, что этих недостатков лишена сетевая форма организации научно-производственного цикл.

В экономике под сетью понимается способ регулирования взаимозависимости участников единого технологического процесса (отличающийся от координации их деятельности с помощью рыночных механизмов), основанный на кооперативной «игре», и особых отношениях².

Переход от чисто рыночных к сетевым отношениям кооперирующихся фирм в конце XX в. назван сетевой революцией. За последние годы по этой проблеме издано более 100 монографий (преимущественно в США, Великобритании, ФРГ). Эти работы посвящены анализу конкуренции в сетевых организациях, природе менеджмента снабженческих сетей и кооперативной стратегии в сетях, динамике межфирменного сотрудничества в сетевых альянсах.

Основоположником кластерной концепции развития новых производственных сетей является М. Портер ${ }^{3}$, который описал идеальный тип кластера. Клаcmep - это группа близких, географически взаимосвязанных компаний и сотрудничающих с ними организаций, совместно действующих в определенном виде бизнеса, характеризующихся общностью направлений деятельности и дополняющих друг друга. Они создают основу для притока иностранных инвестиций, обучения широкого круга предпринимателей, развития малого и среднего предпринимательства, повышения гибкости и мобильности компаний, создания широкого спектра сетевых структур. Кластеры позволяют оптимизировать межфирменные контакты, наладить эффективную кооперацию, согласовывать планы бизнессубъектов - различных организаций участвующих в инвестиционно-строительной деятельности. Одновременно кластеры выступают и как форум, в рамках которого ведется диалог между деловыми, правительственными и научными кругами о путях развития конкурентных преимуществ в рамках региона, страны. Таким образом, кластер является новой формой сетевой организации межфирменного взаимодействия, позволяющей быстро, инновационно адаптировать внутренние структуры и внешние взаимосвязи к быстро меняющейся внешней среде. ${ }^{4}$

Документом «Декларация об укреплении экономического сотрудничества в Европе» (1997 г.) и «План действий», детализирующий первый документ, провозглашают формирование новых производственных систем на основе сетей и кластеров в качестве одного из наиболее актуальных направлений развития европейского сотрудничества. Активное развитие кластеров считаются эффективным направлением инновационной предпринимательской деятельности. Кластерная концепция развития предприятия фокусируется на взаимосвязях между корпора-

1 Подробнее см.: Асаул А.Н. Формирование мезоэкономических объединений в инвестиционно-строительном комплексе региона//Известия вузов.-Строительтво.-2004.-№ 1.

${ }^{2}$ Подробнее см.: Асаул А.Н., Денисова И.В. Интеграция строительных фирм в форме сетевых индустриальных организаций/Регион: политика, экономика, социология. 2001. № 1. С. 61-64.

${ }^{3}$ Портер М. Международная конкуренция. -М., 1993.

${ }^{4}$ Бляхман Л.С., Петров А.Б. Интегрированная технологическая цепь как объект управления в глобальной экономике // Проблемы современной 
тивными структурами ${ }^{1}$, инвестиционными, посредническими, научными, учебными, общественными организациями региона. Суть кластерной концепции, заключается в реализации консолидированного потенциала регионов, экономическая территория которых является основой для развития европейского сотрудничества, а решение проблем региональной экономики - одно из главных направлений деятельности европейского сообщества.

За последние два десятилетия развитие новых производственных структур получило широкое распространение не только в странах европейского союза (Австрии, Италии, Финляндии, Франции), но и в европейских странах с переходной экономикой, в развивающихся странах (Индии, Нигерии, Чили, Гане), а также в арабском мире в Марокко, Иордании, Сирии, Ливане, Египте, Саудовской Аравии, Объединенных Арабских Эмиратов и др.)

Мировой опыт создания новых производственных систем на основе сетевых структур - кластеров стал темой Первого всемирного конгресса в Париже (январь 2001 г.), проведенного по инициативе Организации сотрудничества и развития (OECD) и ряда других (LEED, DATAR, UNIDO и др.).

Развитию этих новых производственных систем посвящены две конференции (2001 г. Киев ${ }^{2}$ и 2003 г. Луцк ${ }^{3}$ ), организованные Союзом экономистов Украины, и Международный экономический форум (2001 г.-Киев), организованный Министерством экономики и вопросов европейской интеграции Украины. На конференциях рассматривались перспективы и пути внедрения новых организационноэкономических технологий управления региональным развитием на основе создания сетевых производственных систем как вертикальных, так и горизонтальных.

Центральной европейской инициативой (C.E.I.) разработаны принципы кластеризации для 5 стран Вышеградской группы, в которую входят Венгрия, Польша, Словакия, Словения и Чехия (в С.Е.І. входят 17 государств). C.Е.І. выявляет основные проблемы и препятствия на пути кластеризации и определяет основные положения кластерного анализа и вырабатывает на их основе свод стратегических рекомендаций для регионов. С.Е.I. содействует развитию сотрудничества между местными и региональными партнерами, частными и государственными структурами, проводит исследования кластеров, определяет перспективы их развития и решает связанные с ними проблемы.

${ }^{1}$ Подробнее см.: Асаул А.Н., Батрак А.В. Корпоративные структуры в региональном инвестиционно строительном комплексе. М.: Изд-во АСВ;СПб.: СПбГАСУ, 2001.

${ }^{2}$ Г. Киев, III съезд Союза экономистов Украины (31 октября-2 ноября): «Світовий та вітчизняний досвід запровадження нових виробничих систем (кластерів) для забезпечення економічного розвитку територій». Подробнее см.: Асаул А.Н. Сетевые индустриальные организации как форма концентрации производства//Сб. материалов конф. Союза экономистов Украины «Світовий та вітчизняний досвід запровадження нових виробничих систем (кластерів) для забезпечения економічного розвитку територій». Киев, 2001.

${ }^{3}$ Г. Луцк, II Пленум Союза экономистов Украины, межобластная школа-семинар «Новые производственные системы: мировой опыт и разработка моделей для обеспечения повышения экономического роста регионов» (30-31 января). Подробнее см.: Асаул А.Н. Развитие новых региональных производственных систем на основе самоорганизации//Матеріали економічного самміту м. Луцьк, 30 січня 2003 року, Киев, 2003. 
Страны Вышеградской группы переориентировали свою государственную политику в сторону европейского рынка и являются наиболее последовательными в реализации кластеризации. Эти страны имеют более благоприятные показатели, чем другие страны с переходной экономикой, в области иностранных инвестиций и снижения инфляции. Из 27 восточноевропейских стран с переходной экономикой страны Вышеградской группы за 11 последних лет сумели превзойти уровень ВНП, который они имели до начала реформ. Этому в немалой степени способствовало внедрение новых производственных систем - кластеров. На постсоветском пространстве лидером в реализации мирового опыта создания производственных систем на основе кластеров является Украина.

Невзирая на трудности переходного периода (бессистемность в подходе к проведению реформ, отсутствие синхронности при вводе законов, противоречия между нормативными актами и содержанием конституции, в начале 1998 г. в Подольском регионе (Хмельницкая, Винницкая и Тернопольская обл.) сформировались 3 кластера: строительный, швейный, и агропромышленный. Был создан Управляющий комитет неправительственной общественной организации «Поділля Перший» (PPNGO), целью которой являлось развитие предпринимательской активности посредством консолидации государственных органов власти, муниципальных образований региона (городов Каменец-Подольского, Староконстантинова, Грицива и др.), научных организаций (например, Хмельницкого технологического университета), различных агентств и ассоциаций, предпринимательских кругов и банковских структур (Укрсоцбанк, Хмельницкая торговопромышленная палата). Деятельность «Подольского» кластера основана на добровольном вхождении в кластер и финансовой поддержке малого бизнеса. Это привело к повышению инновационности выпускаемой продукции и реализации мощного регионального интеллектуального потенциала ${ }^{1}$.

Строительный кластер Подольского региона Украины насчитывает около 30ти предприятий строительной отрасли, которые специализируются на выполнении строительно-монтажных работ, производстве строительных материалов, проектировании, дизайне и обеспечивают выполнение полного цикла строительных работ, со сдачей объектов «под ключ». В кластер входят также предприятия и учреждения инфраструктуры, которые предоставляют торговые, юридические, аудиторские, маркетинговые, информационные, образовательные и научноисследовательские услуги (рис. 3.1). ${ }^{2}$

Основные достижения: 1. За 2 года деятельности кластера сдано в эксплуатацию более 10-ти объектов жилищного, бытового и промышленного назначения. 2. За 2003 год предприятиями кластера освоено 3,85 млн. долл. США, произведено собственной продукции на 1404 тыс. дол. США, создано 480 новых рабочих мест. 3. За счет сокращения сроков строительства и себестоимости 1 метра квадратного снижено стоимость жилья на $10 \%$. 4. Привлечено дополнительных инвестиций в регион в суме - 750 тыс. дол. США. 5. За счет внедрения новых технологий тру-

${ }^{1}$ Войнаренко М.П. Кластерные технологии в системе развития предпринимательства, интеграции и привлечения инвестиций.

2 Малый Н. Кластер - новая форма предпринимательского объединения. http// www.unece.org/ie/wp8/documents/novsem.htm 
доемкость строительных работ уменьшена на 15\%. 6. Создана школа подготовки и повышения квалификации специалистов строительной сферы города.

Строительный кластер отличается от других типов объединения тем, что имеет значительно более широкое членство и цели. Кластер объединяет все компоненты производственного процесса, от поставщиков сырья к потребителям конечного продукта, включая сферу обслуживания и специализированную инфраструктуру.

При этом, основной целью объединения является достижение конкретного экономического результата - производство конкурентоспособного продукта, что способствует повышению эффективности деятельности каждой отдельной организации, и ускорению развития экономики региона в целом.

1. Формирование единого информационного пространства, когда через взаимодействие головной организации с организациями-участниками вырабатывается новая информация, становящаяся движущей силой деловой активности.

1.1. Генерация и обмен новой информацией: изучение и распространение опыта по созданию и работе фондов развития жилищного строительства с последующим внедрением в организациях, входящих в корпорацию; обеспечение организаций информацией о мерах по снижению стоимости строительства за счет внедрения эффективных технологий, материалов и оборудования; доведение до организаций информации о конъюнктуре цен на основные виды отечественных и зарубежных материалов; организация семинаров-совещаний, учебных семинаров. 


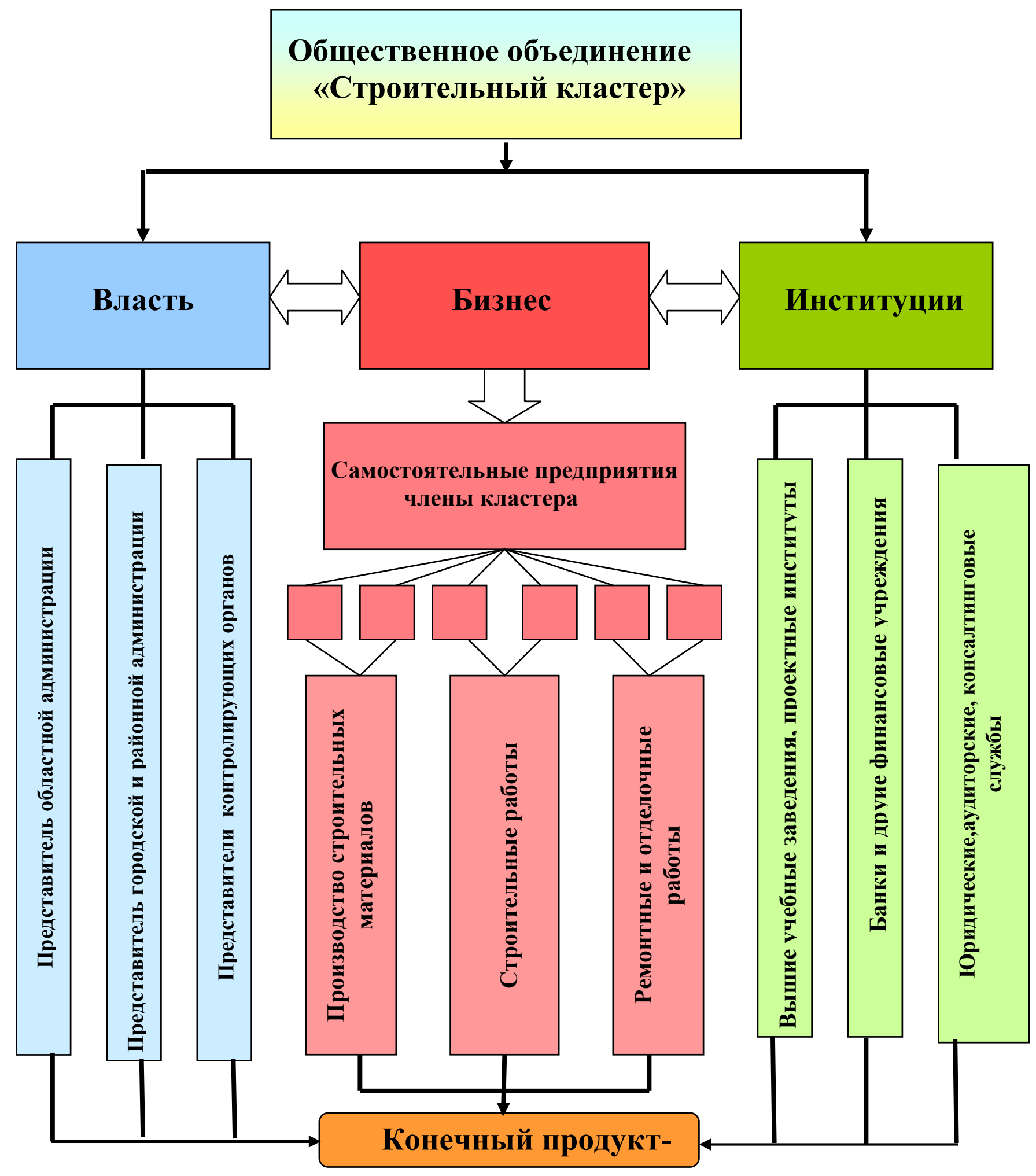

Рисунок 3.1 - Модель строительного кластера

Преимущества объединения в кластер:

1.Возможность привлечения финансовых ресурсов в строительную сферу - 
(путем объединения общих финансовых возможностей участников кластера, привлечения инвестиций, совместное участие в конкурсах проектов, которые финансируются в виде грантов, объединение общих финансовых возможностей для обеспечения гарантий на получение кредитных ресурсов).

Так, объединение финансовых ресурсов участников кластера, дало возможность на базе одного из участников кластера организовать производственную линию по выпуску сухих строительных смесей. Это дало возможность всем участникам кластера перейти на использование собственных сухих смесей.

2. Возможность снижения себестоимости строительной продукции и услуг организаций входящих в кластер.

Наличие собственного производства на основе местной сырьевой базы, способствует снижению затрат на транспортировку, сохранение, торговые услуги, что в свою очередь удешевляет себестоимость жилой площади и ремонтных работ. Более того, не возникает проблем со сбытом: продукция полностью используется внутри кластера.

3. Объединение более 30 предприятий строительной сферы Подольского региона, дало возможность участникам кластера эффективно отстаивать свои интересы на уровне органов местной власти и местного самоуправления.

Благодаря кооперации совместных усилий участников кластера, получена поддержка и доверие власти. Так, совместно с Хмельницким горисполкомом разработана долгосрочная программа «Современное жилье», которая предусматривает на протяжении 2003-2010 лет строительство в областном центре 5-ти многоэтажных жилых домов улучшенной планировки.

4. Реализация участниками кластера программы «Современное жилье» - это обеспечение постоянной загруженности организации строительной отрасли и смежных отраслей; создание новых рабочих мест; содействие возрождению промышленности отдельных районов области, где находятся месторождения полезных ископаемых, которые используются в строительстве. Так, на данный момент создан кластер строительных материалов (кирпич, рубероид, фаянс, др.), который охватывает Славутский, Шепетовский, Полонский, Теофипольский и Белогорский районы Хмельницкой области, другие регионы Украины. Кроме того, реализация данной программы предусматривает внедрение новой каркасно-монолитной технологии строительства жилья, что было бы невозможно, при условиях деятельности предприятий в условиях рынка поодиночке. ${ }^{1}$

5. Объединение организаций на уровне региона - принципиально новый уровень отношений, который базируется на порядочности и доверии между участниками кластера и можно сказать новый способ мышления 2 .

Итак, кластер - это отраслевое, территориальное и добровольное объединение предпринимательских структур, которые тесно сотрудничают с научными (образовательными) учреждениями, общественными организациями и органами мест-

${ }^{1}$ Подробнее см.: Асаул А.Н., Иванов С.Н. Современные проблемы и тенденции формирования системы управления региональным инвестиционно-строительным комплексом//Сб. Науч. труды Вып. III. Международная академия менеджмента М., 2002. С. 37-50.

2 Малый Н. Кластер - новая форма предпринимательского объединения. http// www.unece.org/ie/wp8 
ной власти с целью повышения конкурентоспособности собственной продукции, работ или услуг и содействия экономическому развитию региона. В кластер входят многочисленные организации смежных, взаимодополняющих отраслей и другие структуры, которые играют важную роль в создании конкурентной среды: университеты и исследовательские учреждения, организации, осуществляющие подготовку кадров, и отвечают за информационное, и техническое обеспечение, торговые ассоциации и др. Подобные объединения оказывают положительное влияние не только на отдельные организации, но и ни экономику региона в целом. ${ }^{1}$

Характерной особенностью кластеров, несмотря на масштабы их образований или отраслевую принадлежность, является их направленность на создание и производство конкурентоспособной продукции, работ или услуг которая может быть экспортирована за границу, или по крайней мере за пределы региона. Как правило, кластеру не присуща ориентация на внутреннего потребителя. Создание строительного или жилищно-коммунального кластера - это особая форма кластерной модели, поскольку и строительство и жилищно-коммунальное хозяйство это вид деятельности, ориентированный прежде всего на внутренний рынок и основной продукцией которой является строительство и обслуживание современного комфортного жилья ${ }^{2}$.

Для того, чтобы кластер состоялся как жизнеспособная, самодостаточная, успешная и эффективная организация необходимо наличие следующих основных условий (рисунок 3.2.)

ИНИЦИАТИВА - инициативные и влиятельные люди из числа предпринимателей, структур власти, общественных организаций, учебных заведений и научных организации, способные своим авторитетом, умом, организаторскими способностями и знаниями сплотить, заинтересовать и на деле доказать полезность кластеров как для самих их членов, так и для региона;

ИННОВАЦИИ - новые технологии в организации производства, сбыта, управления, финансирования, способные открыть новые возможности в конкурентной борьбе;

ИНФОРМАЦИЯ - через взаимодействие головной организации с организациями-участниками вырабатывается новая информация, которая становится движущей силой деловой активности. Формируется единое информационное пространство.

ИНВЕСТИЦИИ - участие в новых инвестиционных проектах. Опыт развитых стран свидетельствует, что кластеры привлекают гораздо больше инвестиций, чем отдельные компании.

ИНТЕГРАЦИЯ - производство и реализация комплектующих изделий, оборудования, инструмента, технологий, ноу-хау и других нематериальных активов, со-

${ }^{1}$ Соколенко С.И. Производственные системы глобализации: Сети. Альянсы. Партнерство. Кластеры: Укр. Контекст. - Киев: Логос, 2002.

${ }^{2}$ Подробнее см. Асаул А.Н. Маркетинговые аспекты деятельности строительной организации/Маркетинг.-2002.-№ 1.

${ }^{3}$ Авдашева С.Б., Дементьев В. Акционерные и неимущественные механизмы интеграции в российских бизнес-группах //Российский Экономический журнал № 1, 2000. 
зданных по заказу головной организации предпринимательской сети предназначены для изготовления конкурентной продукции и не могут быть реализованы на свободном рынке для широкого потребителей.

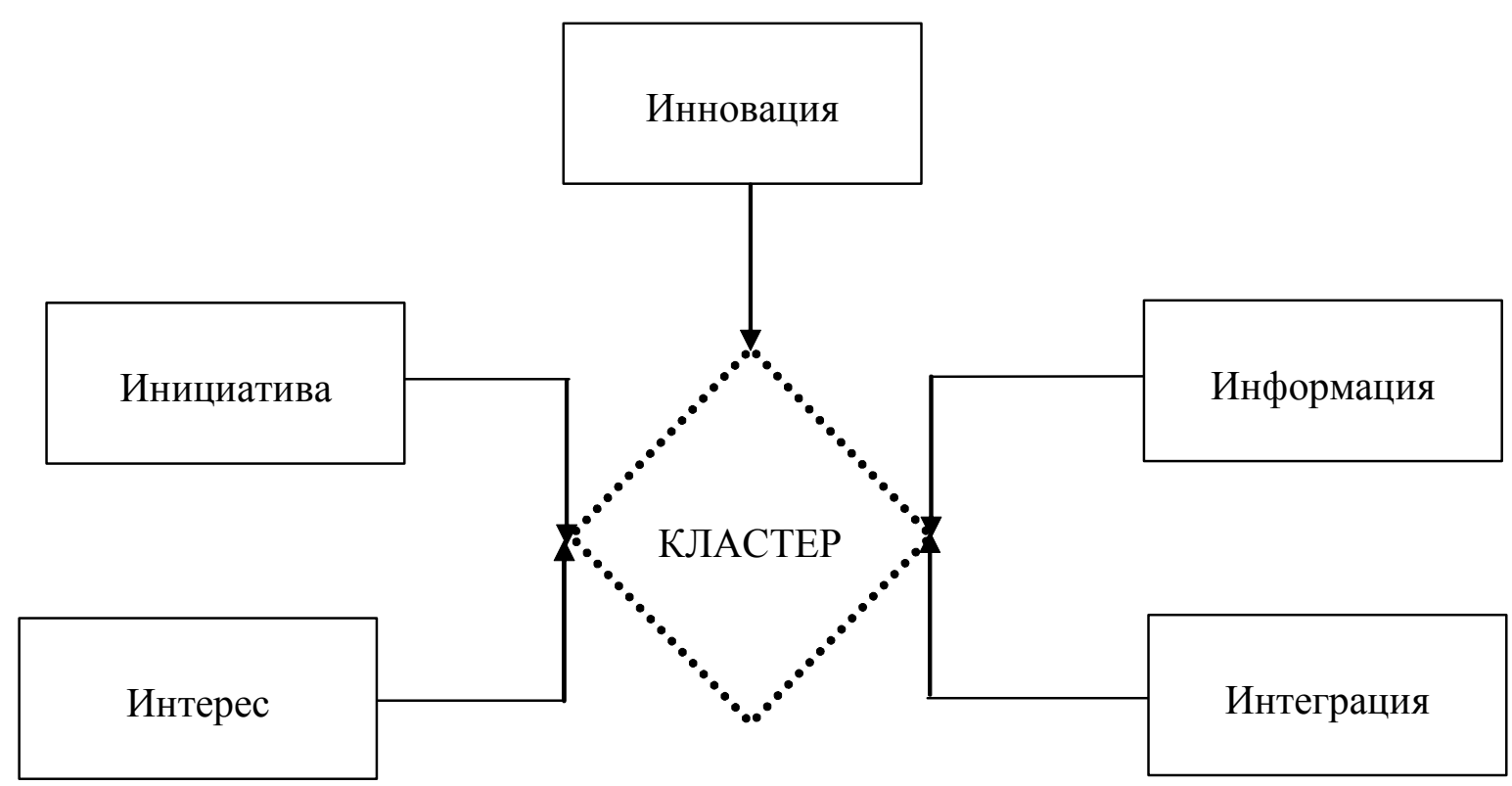

Рисунок 3.2. - Необходимые условия создания кластеров (Концепция "5-И” М.Войнаренко)

ИНТЕРЕС - обеспечивает основное условие жизнедеятельности предпринимательской или общественной структуры, предполагающей наличие заинтересованности участников кластерных объединений и получение ими определенной экономической выгоды.

Экономические связи, лежащие в основе создания кластеров, основаны на долгосрочных контрактах (в отличие от холдингов, базирующихся на имущественных интересах) и осуществляются на основе вертикальных и горизонтальных взаимодействий между различными бизнес-субъектами и их симбиозной взаимозависимости, определяемой принципом синергизма'. Такие объединения позволяют малым организациям сочетать преимущества малых форм предпринимательства и крупных производств². Между фирмами, принадлежащими разным собственникам, возникает родство при сохранении каждой из них своей автономности.

В кластере элементы рынка сочетаются с иерархической координацией дей-

${ }^{1}$ Подробнее см.: Асаул А.Н. Роль европейского сотрудничества в развитии новых производственных систем//Науч. тр. Международного союза экономистов и Вольного экономического общества России (Ежегодное Собрание членов Международного Союза экономистов «Роль и место европейского сотрудничества в развитии мировой экономики». Германия-АвстрияСловакия-Венгрия, 17.10.2003-26.10.2003). -М.-СПб., Вольное экономическое общество, т. 13, 2004.

${ }^{2}$ Подробнее см.: Асаул А.Н., Денисова И.В. Проблемы и тенденции развития малого предпринимательства на региональном уровне//Науч. труды Международного союза экономистов и Вольного экономического общества России Т. 11 М.; СПб. 2002. С 211-221. 
ствий, но на первый план выходят кооперационные и информационные связи, а имущественные связи могут присутствовать в форме долевого участия.

Кластеры можно идентифицировать как группу фирм-участников того или иного рынка, объединившихся, на основе долгосрочных контрактов, с целью эффективного использования ресурсов и специфических преимуществ для совместной реализации предпринимательских проектов. Используя преимущественно горизонтальные связи, специализацию и дополняя друг друга, они получают возможность для достижения более высоких результатов.

Отличительная черта кластера - целевая предпринимательская деятельность. В рамках кластера объединяется не только производственный, Но и инновационный бизнес, комплексное управление качеством продукции, сервисное обслуживание. Объединение усилий предпринимателей, органов управления, субъектов инвестиционной и инновационной деятельности на определенной территории дает значительные преимущества в конкурентной борьбе, способствует рационализации производственно-рыночных процессов, перераспределению рисков и проведению гибкой политики, необходимой в условиях быстро меняющейся конъюнктуры. Такое объединение усилий в развитых странах оказалось достаточно эффективным.

Главной особенностью кластеров является сетевая форма организации производственного цикла. Экономический эффект от создания кластеров в строительной сфере обусловлен:

производственно-строительной кооперацией, позволяющей эффективно использовать совокупный потенциал сетевых партнеров;

снижением затрат на модернизацию строительной продукции путем передачи части работ партнерам, специализирующимся в конкретных видах деятельности;

повышением эффективности процесса обеспечения строительного производства сырьем, материалами, деталями, конструкциями на основе установления долгосрочных партнерских связей;

повышением эффективности выполнения отдельных управленческих функций за счет разделения труда, специализации, привлечения специализированных организаций строительного профиля;

повышением эффективности работ в области сбыта и сервисного обслуживания, приобретения необходимых ресурсов;

повышением надежности сетевых партнеров в инвестиционно-финансовой кооперации.

Несмотря на общее направление развития инвестиционно-строительной деятельности ${ }^{1}$ и линии поведения в производственных системах, уникальностью каждого региона, безусловно, приводит к разным конечным результатам, тем более что каких-либо устойчивых правил в области кластеризации еще не разработано.

${ }^{1}$ Подробнее см.: Асаул А.Н. Формирование системы управления строительным комплексом в современных условиях/Региональные и отраслевые проблемы инвестиционной деятельности//Материалы международной конференции МАИЭС Владимир, изд-во Владимирского государственного университета, 2002. 


\section{2 Отечественный опыт формирования предпринимательских сетей}

Характеризуя роль и значение предпринимательских сетей в развитии хозяйственного комплекса Российской Федерации целесообразно рассматривать эволюцию предпринимательства, которая инициировала появление объективных предпосылок становления сетевых структур.

В процессе становления рыночной экономики России образовался предпринимательский сектор народного хозяйства. Его формирование осуществлялось путём:

- приватизации и акционирования государственных предприятий;

- создания малых предприятий.

Оба процесса развивались высокими темпами. На начальном этапе реформирования наблюдался активный рост и развитие предпринимательского сектора преимущественно за счет приватизации и акционирования. На последующих стадиях - активизировалось формирование новых предпринимательских структур и трансформация уже созданных. ${ }^{1}$

Совокупность субъектов предпринимательской деятельности, сформировавшихся в годы реформ, образует систему предпринимательства. В нее входят:

- крупные предприятия (преимущественно ОАО, ЗАО, ООО);

- малые предприятия (юридические лица) различной организационной правовой формы;

- предприниматели без образования юридического лица (ПБОЮЛ);

- крестьянские (фермерские) хозяйства;

В предпринимательском секторе экономики трудятся примерно 60 000, в числе малых предприятиях - 6485 тыс. человек, а предпринимателей без образования юридического лица более 10000 человек².

Общий объём выручки предприятий России за 2000 год составил 14562784 млн. руб³. , причём из них на долю крупных и средних предприятий (КСП) приходится 62,5\%, на долю малых предприятий (МП) - 35,3\%, а на долю предпринима-

${ }^{1}$ Подробнее см. Асаул A. Н. Становление предпринимательской деятельности в контексте парадигмы глобализации экономики // Науч. тр. Международного союза экономистов и Вольного экономического общества России. М. - СПб., ВЭО. Т. 10. 2002.

${ }^{2}$ Российское обозрение малых и средних предприятий 2001. - М.: 2002. Савицкая Г. В. Анализ хозяйственной деятельности предприятия: 4-е изд. перераб. и доп. - Минск: ООО «Новое знание», 2000.

${ }^{3}$ Одинщов М. В., Ежкин Л. В. Корпорация и реструктуризация как две стороны реформирования предприятия // Менеджмент в России и за рубежом №6,2000. Российское обозрение малых и средних предприятий 2001. - М.: 2002. Томи-лов В. В., Крупанин А. А., Хакунов Т. Д. Маркетинг и интрапренерство в системе предпринимательства: Учебное пособие. - СПб.: СПбГУЭФ, 1998. 
телей без образования юридического лица $-2,2 \%{ }^{1}$. Малые предприятия в целом показывают лучшие финансовые результаты, чем остальные предприятия. В 2000 году $2 / 3$ малых предприятий закончили год с положительным финансовым результатом. Доля убыточных предприятий в общем, числе хозяйствующих субъектов среди МП ниже, чем среди средних и крупных. В общем, объём прибыли по итогам 2000 года, доля малых предприятий составила чуть более одной десятой части, однако в таких отраслях как строительство и торговля МП формируют более $80 \%$ положительного финансового результата. Каждый работник МП внёс практически вдвое больший вклад в формирование положительного финансового результата по сравнению с занятыми на всех предприятиях в среднем. В смысле рентабельности активов, за последние пять лет малые предприятия были, как правило, эффективней крупных и средних предприятий.

Динамика численности субъектов малого предпринимательства приводится в табл.3.1.

Таблица 3.1

Динамика численности субъектов малого предпринимательства в России (ед.)

\begin{tabular}{|l|l|l|l|l|}
\hline $\begin{array}{l}\text { Субъекты малого } \\
\text { предпринимательства }\end{array}$ & 1998 г. & 1999 г. & 2000 г. & 2001 г. \\
\hline Малые предприятия & 868008 & 890600 & 879334 & 843000 \\
\hline Фермерские хозяйства & 270154 & 261126 & 261677 & 262000 \\
\hline \multicolumn{1}{|c|}{ ПБОЮЛ } & 35976111 & 3875252 & 4236924 & 4497000 \\
\hline
\end{tabular}

Доля малых предприятий в общем, числе предприятий и организаций составила в 2001 году $26,3 \%$. Место малого предпринимательства в отраслевом разрезе представлена в приложении А. В экономике Российской Федерации в 2000-2003 г.г. наблюдаются устойчивые положительные тенденции. Это вызвано отчасти внешними причинами (высокие цены на сырьевые товары, прежде всего, на нефть, на мировых рынках в 2000 году), отчасти - внутренними причинами (оздоровление ряда секторов экономики, рост инвестиционной активности предприятий, рост внутреннего спроса). Рост ВВП в 2002 г. составил 105\% по сравнению с 2001 г. Наблюдается прирост объемов промышленной продукции в ряде отраслей (табл.3.2), если рассматривать период длительностью 4-5 лет.

Таблица 3.2

Динамика производства промышленной продукции в отдельных отраслях $(\%$ к предыдущему году)

\begin{tabular}{|l|c|c|c|c|c|}
\hline & 1997 & 1998 & 1999 & 2000 & 2001 \\
\hline $\begin{array}{l}\text { Промышленность - всего } \\
\text { в том числе }\end{array}$ & 102 & 95 & 108 & 109 & 104,9 \\
\hline электроэнергетика & 97,9 & 97,5 & 100,2 & 101,8 & 101,6 \\
\hline топливная промышленность & 100,3 & 97,5 & 102,4 & 105 & 106,1 \\
\hline черная металлургия & 101,2 & 91,9 & 114,4 & 115,6 & 99,8 \\
\hline
\end{tabular}

${ }^{1}$ Томилов В. В., Крупанин А. А., Хакунов Т. Д. Маркетинг и интрапренерство в системе предпринимательства: Учебное пособие. - СПб.: СПбГУЭФ, 1998. 


\begin{tabular}{|l|c|c|c|c|c|}
\hline цветная металлургия & 105 & 95 & 108,5 & 111,3 & 104,9 \\
\hline $\begin{array}{l}\text { химическая и нефтехимическая промышлен- } \\
\text { ность }\end{array}$ & 102 & 92,5 & 121,7 & 114,3 & 106,5 \\
\hline машиностроение и металлообработка & 103,5 & 92,5 & 115,9 & 115,5 & 107,2 \\
\hline $\begin{array}{l}\text { лесная, деревообрабатывающая и целлюлозно- } \\
\text { бумажная промышленность }\end{array}$ & 101,2 & 99,6 & 117,2 & 109,5 & 102,6 \\
\hline промышленность строительных материалов & 96,6 & 94,2 & 107,7 & 107,6 & 105,5 \\
\hline легкая промышленность & 97,6 & 88,5 & 120,1 & 122 & 105,0 \\
\hline пищевая промышленность & 99,2 & 98,1 & 107,5 & 107 & 108,4 \\
\hline
\end{tabular}

Можно предположить, что положительные тенденции в экономике страны связаны не в последнюю очередь с деятельностью предпринимательского сектора народного хозяйства. Его развитие будет осуществляться путём:

- дальнейшей приватизации госпредприятий;

- продажей государственной собственности в ряде акционерных обществ;

- создания новых малых и средних предприятий.

Любой представитель системы предпринимательства определённым образом взаимодействует с другими субъектами предпринимательской деятельности. Современное предприятие не может быть универсальным. Оно специализируется на изготовлении какой-либо продукции (услуге) и устанавливает деловые контакты, хозяйственные связи с поставщиками сырья, с изготовителями комплектующих деталей и узлов, с продавцами и т. д. Разделение и кооперация труда являются объективными факторами современной экономики, обеспечивающими эффективность производства за счёт применения специализированного высокопроизводительного оборудования, использования кадров высокой квалификации и т.д. В современном народном хозяйстве существуют отраслевая специализация (строительство, машиностроение, лесозаготовки, лесопереработка и т.д.). Предприятия специализируются на изготовлении различных видов изделий (тракторов, автомобилей, мебели и т.д.); на выполнении различного рода научно-исследовательских опытов, конструкторских и проектных работ; на оптовой и розничной торговле; на сервисном обслуживании различной техники и т.д. Рассматривая всю совокупность субъектов предпринимательства можно их успешно разделить на три группы:

- организации, функционирующие автономно;

- организации, функционирующие с определённой степенью взаимодействия;

- предприятия (организации), функционирующие в составе объединения, имеющего свою специфическую организационную структуру ${ }^{1}$.

Характеристика системы предпринимательства в интеграционном аспекте представлена на рис.3.1. Субъекты предпринимательства, функционирующие автономно, решают свои задачи во внешней среде путём разовых контактов. Чаще всего это действия по покупке (продаже) сырья, материалов, изделий на соответ-

${ }^{1}$ Головина А.Н. Методология разработки проблемы специализации и кооперации, производства в условиях трансформируемой экономики // Известия Уральского университета, 1999. Доничев О.А. Предпринимательство в строительном комплексе. // Российский экономический журнал №7, 1995. 
ствующих рынках, без налаживания длительных партнёрских связей. Многие предприятия устанавливают длительные деловые связи с другими организациями, которые становятся их стабильными партнёрами. На этой основе осуществляется производственная кооперация, ресурсное обеспечение, защита общих интересов и т.д. Эти партнёрские отношения реализуются на основе долгосрочных контактов и договоров и т.д. при сохранении участникам полной юридической самостоятельности ${ }^{1}$.

Ряд предпринимательских субъектов осуществляет интеграционное функционирование в составе различного рода производительно-хозяйственных объединений частично или полностью теряя свою юридическую и административную самостоятельность ${ }^{2}$.

Основные направления взаимодействия бизнес субъектов представлены на рис.3.2.

Основной целью интегрированного функционирования бизнес субъектов является решение собственных тактических и (или) стратегических задач путём привлечения и использования возможностей предприятия - партнёра. Такое функционирование необходимо для:

1. надёжного обеспечения предприятия сырьём и полуфабрикатами, надёжного снабжения комплектующими изделиями;

2. производственная кооперация;

3. выполнения отдельных технологических процессов, требующих уникального, дорогого, сложного в эксплуатации оборудования;

4. выполнения НИОКР, конструирования, проектирования, изготовления, транспортировки, сбыта, сервисного обслуживания и т.д.;

5. реагирование на изменение, увеличение спроса при ограниченных производственных мощностях и т. п.;

6. концентрация производства на базе интеграции отдельных юридических самостоятельных бизнес субъектов;

7. привлечение на взаимовыгодной основе ресурсов партнёров (финансовых, производственных) и прочие для решения различных актуальных задач.

${ }^{1}$ Вахмистров А. И., Асаул А. Н. Роль корпоративных объединений в системе управления региональным строительным комплексом. - СПб.: Стройиздат, СПб., 2003. Вороновиџкий М. М. Перекрестная собственность как механизм вертикальной интеграции на товарных и финансовых рынках / Экономика. и математические методы, 1997. Драчева Е. Л., Либман А. М. Проблемы определения и классификации интегрированных корпоративных структур // Менеджмент в России за рубежом №4, 2001.

2 Горбунов А. Р. Дочерние компании, фирмы, холдинги: Организационная структура создания кредитных союзов. - М.: «Анкил», 1999. 


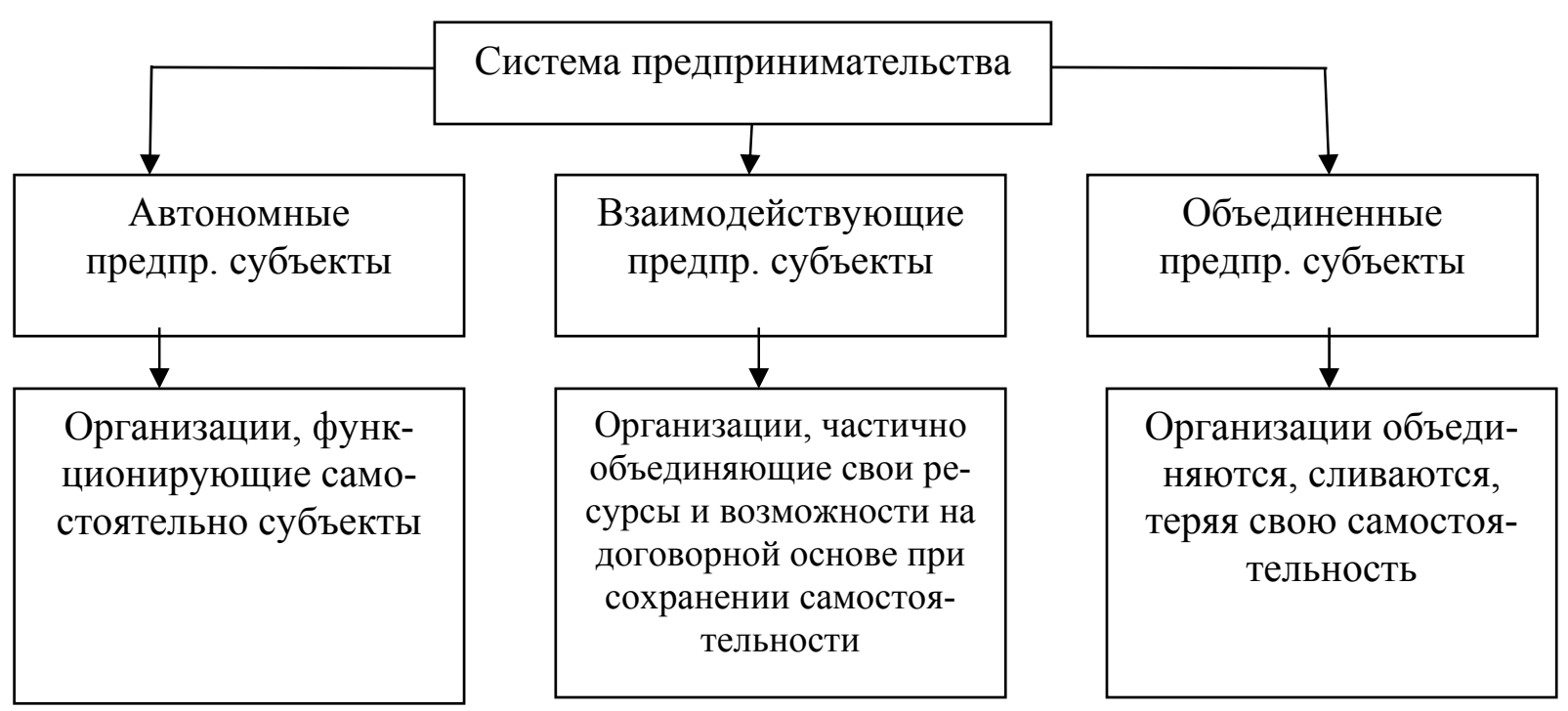

Рисунок 3.3. Характеристика системы предпринимательства (интеграционный аспект)

Одной из целей взаимодействия организаций является получение партнёрского кредита. Его наиболее значимые преимущества: длительные сроки, на которые можно получить кредит; меньшие процентные ставки по сравнению с банковским кредитом; высокая оперативность в получении такого рода кредитов. Это определяется следующими факторами. Во-первых, предприятие-партнёр, предоставляющее кредит, обладает более широкими представлениями о производственных рисках, более информировано о реальном финансовом положении партнёра. Вовторых, оно, по сравнению банком, обладает дополнительными рычагами воздействия на заёмщика благодаря наличию хозяйственных связей. Наличие таких связей между заёмщиком и кредитором, с одной стороны, создаёт основу для погашения кредита в неденежной форме, а с другой стороны, позволяет увеличить "горизонт кредитования". В-третьих, партнерский кредит, может предоставляться без оформления каких-либо документов, что существенно снижает уровень налогообложения данной формы кредитования по сравнению с банковским кредитованием. В-четвертых, партнерский кредит в форме займов организаций-партнеров носит, зачастую, взаимный характер: в зависимости от ситуации одно и то же предприятие выступает то кредитором, то заемщиком. Возможности по привлечению партнерского кредита в известной мере связаны с типом контроля за предприятием. В случае фирм, контролируемых внешними собственниками, данные возможности объективно несколько шире по сравнению с предприятиями, контроль которых осуществляется директором. Это происходит потому, что внешний собственник более часто управляет несколькими фирмами, что обеспечивает необходимую основу для оперативной "переброски" ресурсов между предприятиями в рамках собственного бизнеса ${ }^{1}$.

1 Экономическая стратегия фирмы/ Под ред. А.П. Градова. - СПб.: Специальная литература, 1995. 


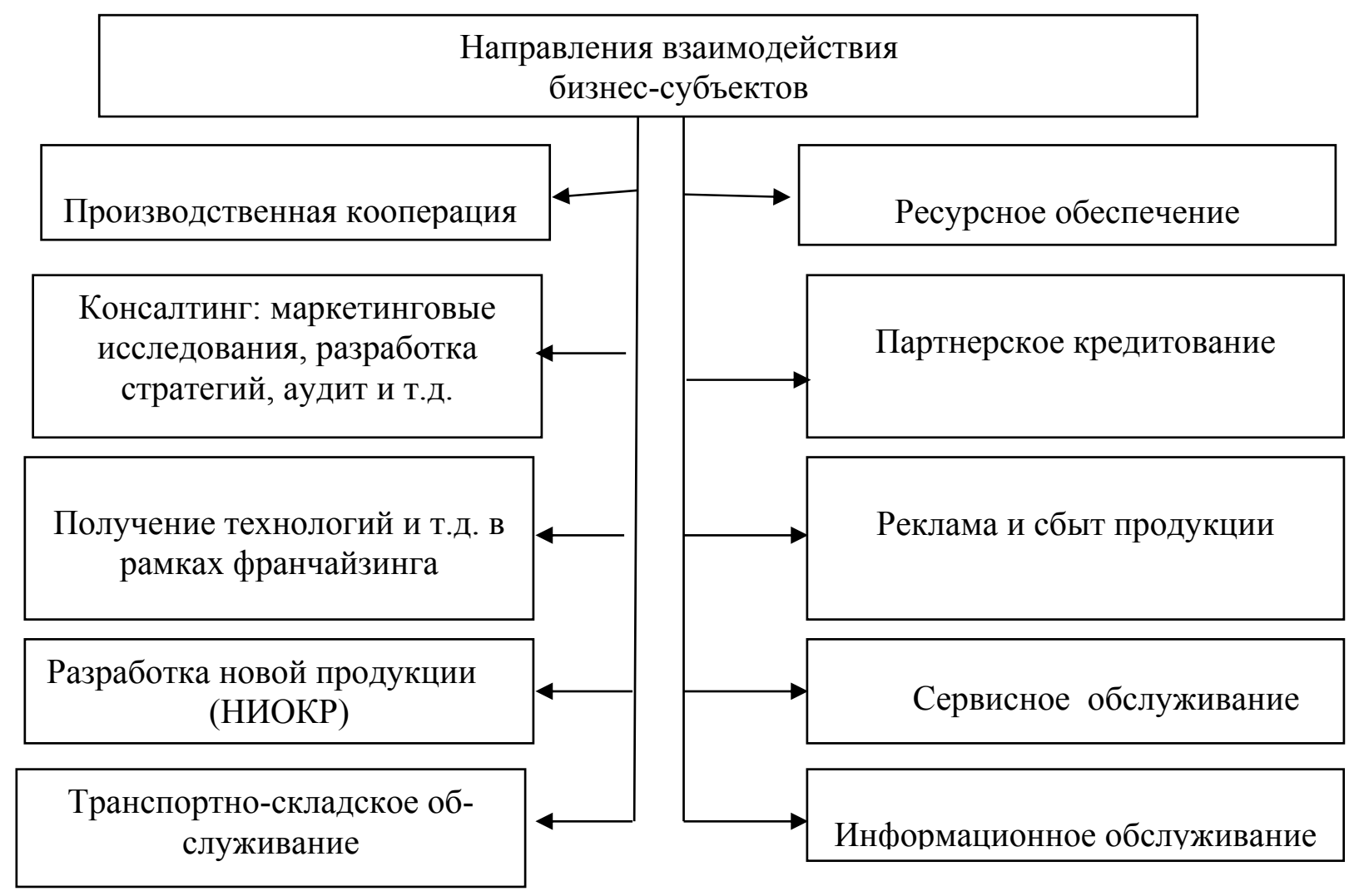

Рисунок 3.2.-Основные направления взаимодействия бизнес-субъектов

Тенденции развития современных организаций показывают, что в зависимости от ставящихся целей и задач, они решают задачи объединения в интегрированные хозяйственные комплексы на основе принципов кооперации. Это основа управления современными производственными процессами, развивающимися в различных отраслях и сферах. От того, на сколько разумно и четко организовано бизнес-взаимодействие, как быстро устраняются возникающие организационные, технологические, финансовые и прочие проблемы, во многом зависит конечный экономический результат ${ }^{1}$.

Разумная устойчивая кооперация возникает, прежде всего, тогда, когда экономически самостоятельные организации видят в этом обоюдную выгоду.

Организации кооперируются, как правило, для совместного выполнения крупных проектов, для осуществления единых задач и координации поведения на рынке, внедрения инноваций. Интеграция на основе кооперации может быть временная и постоянная и принимать различные организационные формы. Она может быть организована как по отраслевому признаку (межотраслевая и внутриот-

${ }^{1}$ Авдашева С. Б. Хозяйственные связи в российской промышленности: проблемы и тенденции последнего десятилетия.- М.: ГУ-ВШЭ, 2000. Вороно-виикий М. М. Перекрестная собственность как механизм вертикальной интеграции на товарных и финансовых рынках / Экономика и математические методы, 1997. Головина A. H. Методология разработки проблемы специализации и кооперации, производства в условиях трансформируемой экономики // Известия Уральского университета, 1999. Портер М. Конкуренция: Учебное пособие. - СПб.: М.: Киев: Изд-во «Вильянс», 2000. 
раслевая кооперация) так и по территориальному признаку (межрегиональная и внутрирегиональная кооперация), а так же кооперация на межгосударственном уровне ${ }^{1}$.

Внутрифирменная кооперация может быть организована, как предметная, подетальная, узловая, и технологическая. Главное добиться более четкой организации производства и сокращения издержек.

В современных условиях внутрифирменная концентрация может происходить как без изменения юридического статуса предприятий - участников интеграционных процессов (например, в случае образования консорциумов, союзов, финансово промышленных групп), так и с потерей такой самостоятельности. Примером такого рода может служить создание концернов ${ }^{2}$.

Внутрифирменная концентрация сочетается с интеграцией бизнес-субъектов в формах горизонтальной и вертикальной интеграции, а также диверсификации.

В случае горизонтальной интеграции, границы нового структурного образования трансформируются вширь. Такое образование сосредотачивает все больший объем производства однотипной продукции. Эта интеграция в пределах одной отрасли, которая изменяет рыночную структуру отрасли. Если повышение концентрации в отрасли находится в пределах допустимого то и существенно не снижает конкуренцию и дает эффект от увеличения масштабов производства, такое слияние допустимо и желательно. Если слияние может привести к монопольному положению объединения, то оно противоречит антимонопольному законодательству.

Зарубежный опыт показывает, что различные формы интеграции являются одним из основных путей развития бизнеса

Вертикальная интеграция - это появление новых структур в результате объединения организаций, как правило, относящихся к разным отраслям, по принципу технологической связанности производственных процессов, восходящей - от конечной к начальным стадиям технологического цикла; и нисходящей - от начальных стадий к конечным.

Частным случаем концентрации является комбинирование производства. Этот процесс представляет собой построения различных комбинаций производств, тес-

${ }^{1}$ Авдашева С. Б., Дементьев В. Акционерные и неимущественные механизмы интеграции в российских бизнес-группах // Российский экономический журнал №1,2000. АсаулА. Н., Иванов C. H. Актуальность создания и эффективное управление корпоративными строительными структурами петербургского региона / Международная академия менеджмента. Научн. тр. Вып. IV. М., 2003. Гурков И. Б. Адаптация промышленной фирмы. - М.: ГУ-ВШЭ, 1997.

${ }^{2}$ Головина А. Н. Методология разработки проблемы специализации и кооперации, производства в условиях трансформируемой экономики // Известия Уральского университета, 1999. Джордж Т. М., Тис Д. Д. Конкуренция и кооперация в стратегии американских корпораций.- В кн.: Уроки организации бизнеса // Сост. Демин А.А., Катькало В.С.- СПб.: Лениздат, 1994. Котлер Ф. Основы маркетинга. - М.: Бизнес-книга, Има-Кросс Плюс, 1995.

${ }^{3}$ Интегрированные финансово-управленческие структуры. Под ред. А. А. Тур-чака. СПб.: Изд-во Наука, 1996. Пивоваров И. С. Стратегический менеджмент холдинга. - СПб.: Печатный двор, 1994. Управление строительными инвестиционными проектами: Учебное пособие / СПбГАСУ: Под ред. В. М. Васильева, Ю. П. Панибратова. - М: СПб.: Изд-во СПбГАСУ, 1997. Частный бизнес: становление и развитие в регионах России.- МАЦ-ИСАРП, 1998. Ogus A. Pourguoi et comment song-traiter-Entreprise moderne d'egition, 1993. Roubet $V$. La pratigue de la sowstraitance-Eclitions du Moniteur, 1991. Rey P., StiglitzJ. The Role of Exclusive Territories in Product's Competition // Rand Journal of Economics, 1995. 
но связанных между собой в технологическом, экономическом, и организационном отношениях.

Комбинирование осуществляется с целью комплексного использования всех видов производственных процессов, рационального сочетания отдельных стадий и сокращения общей длительности производственного цикла, снижения стоимости и совершенствование управления производством.

Процесс концентрации производства и интеграции развивается в первую очередь там, где имеются наиболее выгодные условия для централизации и интеграции научно технического промышленного и финансового капитала.

В любом случае объединение предпринимательских структур не должно быть случайным, призвано служить целям укрепления производственного потенциала и улучшения экономических параметров его участников ${ }^{1}$.

В народном хозяйстве России активно формируются предпринимательские объединения на основе имущественных связей, т.е. путем создания дочерних предприятий и так называемых зависимых обществ с перекрестной собственностью (табл.3.3).

В подавляющем большинстве отраслей народного хозяйства (в промышленности, в строительстве, на транспорте) новые интегрированные бизнес-группы (если они не были созданы в процессе приватизации) развиваются на основах, не связанных с имущественными правами.

Развития отраслевой структуры идет по следующим направлениям:

- вертикальная интеграция "назад" - установление контроля над поставщиками;

- вертикальная интеграция "вперед" - установление контроля над потребителями;

- горизонтальная интеграция в рамках основной специализации.

Таблица 3.3

Дочерние и зависимые предприятия в отраслях экономики России

\begin{tabular}{|l|l|l|l|l|l|l|}
\hline \multirow{2}{*}{ Отрасль экономики } & 1997 & \multicolumn{2}{l|}{ На 1.07 .1999} \\
\cline { 2 - 7 } & $1^{*}$ & $2^{* *}$ & $1^{*}$ & $2^{* *}$ & $1^{*}$ & $2^{* *}$ \\
\hline Всего по России & 2727146 & 103422 & 2901237 & 117047 & 2980618 & 120488 \\
\hline Промышленность & & & & & \\
\hline Транспорт & 339406 & 9588 & 352397 & 10139 & 359979 & 10313 \\
\hline Связь & 60071 & 4312 & 67417 & 4840 & 70084 & 5032 \\
\hline Строительство & 11080 & 3939 & 12124 & 4511 & 12480 & 4607 \\
\hline $\begin{array}{l}\text { Торговля и общественное } \\
\text { питание }\end{array}$ & 286977 & 12061 & 298043 & 12476 & 303102 & 12484 \\
\hline $\begin{array}{l}\text { Материально техническое } \\
\text { снабжение и сбыт }\end{array}$ & 39447 & 3717 & 41170 & 3830 & 41677 & 3741 \\
\hline
\end{tabular}

${ }^{1}$ Майзель А. И., Пивоваров И. С. и др. Предпринимательские структуры в рыночной экономике. - СПб.: СПбГУЭФ, 1995. Нестеренко Е. Г. Организационно-экономические основы формирования и функционирования финансово-промышленных групп. - Самара, 1997. 


\begin{tabular}{|l|l|l|l|l|l|l|}
\hline $\begin{array}{l}\text { Финансы, кредит, страхова- } \\
\text { ние, пенсионное обеспече- } \\
\text { ние }\end{array}$ & 50939 & 18537 & 52391 & 18960 & 53053 & 19053 \\
\hline
\end{tabular}

* Количество предприятий в отрасли

** Количество дочерних и зависимых предприятий

Первое направление выглядит перспективным для российских конгломератов. При этом преследуются две цели - нейтрализация двойной надбавки и закрытие рынка для потенциальных конкурентов. Довольно часто попытки интеграции с помощью имущественных прав, когда компании противостоит сопоставимый по размеру контрагент, заканчиваются неудачей.

Интеграция "вперед" часто связывается с установлением контроля над неплатежеспособными потребителями путем конвертации задолженности в акции либо с помощью процедуры банкротства с назначением лояльного кредитора внешнего управляющего. Она практикуется в России сравнительно редко. Ожидаемые выигрыши незначительны по сравнению с затратами на приобретение эффективных конкурентов. Что же касается неэффективных производств, то, хотя издержки на их поглощение невысоки, реструктуризация требует масштабных инвестиций, и для них ожидаемая отдача оказывается несопоставимо мала по сравнению с затратами ${ }^{1}$.

Подавляющее большинство крупных российских интегрированных групп имеют непрозрачные формальные отношения собственности. Преобладающей формой холдинга в большинстве развивающихся групп - является распределенный холдинг². Она типична не только для крупнейших групп, но и для относительно небольших. Распределенный холдинг служит очевидным способом защиты от предела имущественных прав с помощью, как титулов собственности, так и других механизмов. В частности, система распределенного холдинга позволяет обойти ряд законодательных ограничений, предусмотренных в частности, Законом "О конкуренции и ограничении монополистической деятельности на товарных рынках". При прочих равных условиях, чем более запутана система имущественных взаимоотношениях, тем меньшей привлекательностью обладает входящая в сферу воздействия группы предприятие для потенциального инвестора. Среди финансово-промышленных конгломератов России особое место занимают так называемые управленческие группы, в противоположность имущественным. Распространение объединений компаний, не имеющих значительных имущественных связей, отражает особую роль рыночных контрактов в переходной экономике. Из-за высоких внешних трансакционных издержек в переходной эконо-

${ }^{1}$ Интегрированные финансово-управленческие структуры. Под ред. А. А. Турчака. - СПб.: Изд-во Наука, 1996.

${ }^{2}$ Клейнер Г., Качалов Р. Управление малыми многопрофильными корпорациями // Проблемы теории и практики управления №5, 1999. Организация строительного производства: Учебник для вузов / Под ред. Цая Т.Н., Грабового П. Г. - М.: Ассоциация строит. Вузов, 1999. Предпринимательство: итоги, проблемы, перспективы // Под ред. А. И. Муравьева. - СПб.: СПбГУЭФ, 1997. Повышение эффективности функционирования строительного комплекса в современных условиях: Сборник научных трудов / СПбГИЭА / Под ред. В. В. Бузырева. СПб.: СПбГИЭА, 1998. Френкель А. А. Экономика России в 1992-1996 гг.: тенденции, анализ, прогноз. - М.: Финстатинфор, 1996. 
мике фактически граница фирмы расширятся за пределы юридически зарегистрированной организации. Устойчивые контрактные отношения в ряде случаев заменяют внутрифирменные связи. Контракты между юридически независимыми лицами могут начать создание некой "квазифирмы". На уровне разграничения фактических и формальных прав собственности это означает, что контакты между предпринимательскими структурами - как явные, так и неявные - приобретают значительную роль в качестве механизма координации в экономике, в том числе в качестве основы интеграции ${ }^{1}$.

Во многом нерешенной для российской экономики остается проблема монополизации, причем существенной тенденцией именно последнего пятилетия можно считать образование крупных многопрофильных холдингов, диверсификацию деятельности отдельных успешных предприятий. Так некоторые нефтяные компании активно работают на рынке зерна, в оптовой и розничной торговле, крупные металлургические холдинги заметны на рынке продукции машиностроения и пищевой промышленности и т.д. С другой стороны в последние два года остро встала проблема реструктуризации естественных монополий. Фактически, речь идет о коренном изменении всей структуры российской экономики ${ }^{2}$.

Важным направлением интеграционного взаимодействия бизнес-субьектов является установление "промышленного партнерства " или " делегированного" производства. (так называемые субконтрактинг). Субконтрактинг - это сетевая рыночная организация производственного процесса, позволяющая оптимизировать размещение заказов на стороне. Использование "субконтрактинга" способствует установлению эффективных связей между хозяйствующими субъектами различных организационно-правовых форм, что снижает управленческие риски и позволяет рационально использовать имеющиеся у предприятия ресурсы ${ }^{3}$.

Взаимодействие бизнес-субъектов в сфере снабжения связано с подбором партнеров, обеспечивающих предпринимательское звено необходимыми ресурсами на длительный период. При этом возможны инвестиции в развитие их сырьевой базы, в первичную переработку сырья, в развитие транспортных связей 4 .

Одной из форм ресурсного обеспечения является лизинг (аренда). При этом организацией - партнером является лизингодатель. Между бизнес-субьектами возникает совокупность экономических и правовых отношений.

Перспективным видом взаимодействия предприятий является франчайзинг.

В последние годы наблюдается интенсивное развитие отечественных франчайзинговых организаций, которые многое почерпнули из опыта западных фран-

${ }^{1}$ Бухвальд Е., Виленский А. Российская модель взаимодействия малого и крупного предпринимательства // Вопросы экономики №12, 1999. Горбунов А. Р. Дочерние компании, фирмы, холдинги: Организационная структура создания кредитных союзов. - М.: «Анкил», 1999.

${ }^{2}$ Клейнер Г., Качалов Р. Управление малыми многопрофильными корпорациями // Проблемы теории и практики управления №5, 1999.

${ }^{3}$ Карлоф Б. Деловая стратегия. - М.: Экономика, 1992. Организация строительного производства: Учебник для вузов / Под ред. Цая Т. Н., Грабового П. Г. - М.: Ассоциация строит. Вузов, 1999.

${ }^{4}$ Полтавиев С. И., Ворониов Г. И., Березин В. П. Особенности функционирования инжиниринговых фирм в сфере управления строительством. // Экономика строительства №1,1999. Управление строительными инвестиционными проектами: Учебное пособие / СПбГАСУ: Под ред. В.М.Васильева, Ю.П.Па-нибратова. - М.: СПб.: Изд-во СПбГАСУ, 1997. 
чайзоров. Развитие отечественных франчайзинговых организаций может стать наиболее успешной и плодотворной сферой роста франчайзинга из-за культурной и общественной приемлемости продукции или услуг, а также знания российскими предпринимателями местных особенностей.

Сама суть франчайзинга предусматривает мощную систему обучения малому бизнесу. Ни в одном университете предприниматель не получает такого количества практического обучения со стороны опытных, заинтересованных в успехе своих "учеников" преподавателей, как в учебных центрах франчайзоров.

Развитие международного франчайзинга влечет за собой инвестирование значительных иностранных капиталов в российскую экономику. По неофициальным данным американских экспертов даже современная начальная стадия развития российского международного франчайзинга характеризуется иностранными инвестициями в объеме более 600 млн. долл. США.

В феврале 1996 года руководителями ряда малых предприятий и организаций, содействующих развитию малого бизнеса, была учреждена Российская Ассоциация Развития Франчайзинга (РАРФ). Ассоциация оказывает помощь потенциальным франчайзорам - российским фирмам, хорошо развившим свое дело и нуждающимся в дальнейшем его расширении, зарубежным франчайзорам, готовым развивать свое дело в России, потенциальным франчайзи, в роли которых выступают малые представители бизнеса, проводит конференции и семинары с целью ознакомления возможно большего числа бизнесменов с основами франчайзинга ${ }^{1}$.

Поскольку РАРФ является общественной организацией, ее возможности довольно ограничены. Для того чтобы коммерческие компании - франчайзоры, франчайзи, а также различные организации могли способствовать развитию франчайзинга в России, инициативная группа, состоящая из представителей российских и зарубежных франчайзоров, а также РАРФ, создали в 1999 году новую ассоциацию под названием "Ассоциация франчайзинга" (РАФ).

Главными направлениями работы обеих ассоциаций являются:

представление и защита интересов предпринимателей-участников франчайзинга в органах законодательной и исполнительной власти;

содействие разработке и реализации федеральных, региональных и отраслевых программ развития и поддержки франчайзинга;

обучение предпринимателей, желающих работать в системе франчайзинга;

консультации по всему спектру вопросов работы в системе франчайзинга (юридическая, финансовая, организационная помощь, конфликтные ситуации и др.)

информационно-посреднеческая помощь, поиск партнеров, помощь в ведении переговоров и оформлении договорных отношений;

организация выставок, семинаров, периодических и отдельных печатных изданий;

организация международного франчайзинга, в том числе адаптация зарубежной системы франчайзинга к российским условиям, поиск партнеров, анализ рынков, помощь при создании базовых предприятий франчайзинга по лицензиям "

\footnotetext{
${ }^{1}$ Малое предпринимательство. Опыт, проблемы, перспективы: Материалы II съезда малых предприятий и предпринимателей Санкт-Петербурга. - СПб.: ЦПН, 1998.
} 
мастерфранчайзи".

Холдинги, конгломераты, компании, обладающие жесткой иерархической управленческой структурой наряду с отмеченными выше достоинствами имеет существенный недостаток - малую гибкость. Они чаще всего малоадаптивны, инерционны, не могут достаточно быстро и эффективно реагировать на изменения внутренней и внешней среды. Кроме того, такая форма интеграционного взаимодействия неприемлема для многих представителей малого и среднего бизнеса, так как ограничивает их права собственника и свободу действий․․

От этих недостатков свободные организации межфирменных связей на основе формирования предпринимательских сетей.

Предпринимательская сеть (ПС) является, по сути, новой формой организации межфирменного взаимодействия, позволяющая быстро, гибко, инновационно адаптировать внутренние структуры и внешние взаимосвязи в возрастающей неопределенности хозяйственной среды. Перспективным направлением развития предпринимательских сетей в стране является создание сети малых предприятий вокруг крупных. ${ }^{2}$ Во всем мире крупные предприятия передают сервисные и инновационные работы малому бизнесу. Подобная технологии, относятся к кластерным, снижают суммарные издержки производства за счет углубления ее специализации и кооперации ${ }^{3}$.

Проблеме развития кластерных предпринимательских сетей был посвящен ряд выступлений на Четвертой всероссийской конференции представителей малых предприятий. Они показали растущий интерес к развитию данной разновидности предпринимательских сетей. Так в Липецкой области итальянские бизнесмены готовы создавать сеть малых и средних предприятий, работающих на нужды завода бытовой техники "Стинол", принадлежащего итальянской "Мерлони".

На прошедшем в рамках конкуренции "круглом столе" "Взаимодействие малого и среднего бизнеса в ТЭКе" представители малых предприятий, работающих в основном в области нефтедобычи и розничной продажи нефтепродуктов, обсуждали возможности такого взаимодействия в топливно-энергетическом комплексе. По мнению выступающих необходимо покончить с "уравниловкой" в области условий хозяйствования, ведущей малые нефтедобывающие предприятия к банкротству. Единая тарифная, таможенная и налоговая политика, ориентирующаяся на высокие экспортные цены, неприемлема для представителей малого бизнеса, работающих на небольших и истощенных месторождениях и реализующих свою продукцию на внутреннем рынке. Обсуждение развития кластерных сетей показало отсутствие научно-методических проработок данного вопроса. Доля малых предприятий в общей численности бизнес-единиц достаточно велика (см. прило-

${ }^{1}$ Прокопович Д. А. Проблемы сочетания централизованного управления холдингом со стремлением снизить риски // Менеджмент в России и за рубежом №2, 2002. Повышение эффективности функционирования строительного комплекса в современных условиях: Сборник научных трудов / СПбГИЭА / Под ред. В. В. Бузырева. - СПб.: СПбГИЭА, 1998.

2 Подробнее см. Асаул А. Н. Сетевые индустриальные организации как форма концентрации производства // Сборник материалов конференции Союза эко номистов Украины. Киев, 2001.

${ }^{3}$ Полтавцеев С. И., Воронцов Г. И., Березин В. П. Особенности функционирования инжиниринговых фирм в сфере управления строительством. // Экономика строительства №1, 1999. 
жение Б). Растет понимание не только преимуществ специализации, малого бизнеса, но и необходимости использования разных форм производственной и сбытовой кооперации, разделения риска. Формируются новые формы организации и координации производства и межфирменного взаимодействия, как по вертикали, так и горизонтали, в рамках ПС. Одной из важнейших их характеристик считают взаимное соглашение участников придерживаться общих приоритетов и интересов, разработку общей стратегии развития. Предпринимательские сети как бы нивелируют отрицательные черты административной иерархической системы и жесткой рыночной конкуренции ${ }^{1}$. Они особенно эффективны в случаях, когда успех каждого из участников зависит от надежного обмена информацией, ее совместного интегрирования и накопления. Важным принципом формирования предпринимательских сетей является взаимовыгодный обмен ресурсами между кооперирующими участниками. Компания становится членом сети при условии наличия экономии, обеспечиваемой сотрудничеством с другими фирмами. Специализация в рамках ПС должна обеспечивать фирме ключевые конкурентные преимущества. В предпринимательской сети выдвижение фирмы-лидера происходит как бы естественным путем, на основе консенсуса. Наряду со снижением издержек побудительным мотивом для вступления фирмы в ПС является стремление получить доступ к ключевым ресурсам, знаниям, технологии, изменить характер конкуренции, ускорить процесс нововведений, снизить степень риска и т.п. Жизнеспособность и долговременность ПС определяются достижением более высокой производительности, надежности сбыта, наличием справедливых механизмов распределения полученной работы. Коммерческие организации в целях координации своей деятельности, а также представлению и защите общих имущественных и пр. интересов могут по договору объединяться в форме ассоциаций или союзов, являющихся иерархическими организациями. Развитие информационных технологий дает новую возможность для осуществления интеграции и кооперации в рамках альянсов. При этом самостоятельные бизнес-партнеры интегрируют и кооперируют свою деятельность, как будто бы это осуществляется в рамках единой организации. Подобные "виртуальные" организации имеют значительный потенциал для усиления своих конкурентных возможностей, значительно увеличивают гибкость и эффективность деятельности альянса. При этом расширяются и укрепляются связи с поставщиками и потребителями, а также информационные потоки предоставляют возможность для принятия стратегических решений. Ocновные разновидности предпринимательских сетей представлены на рис.3.5.

Ряд авторов выдвигает сетевую теорию взаимодействия бизнес-субъектов ${ }^{2}$.

${ }^{1}$ Малое предпринимательство. Опыт, проблемы, перспективы: Материалы II съезда малых предприятий и предпринимателей Санкт-Петербурга. - СПб: ЦПН, 1998.

${ }_{2}$ Асаул $A$. $H$. Развитие новых региональных производственных систем на основе самоорганизации / Ноеі виробнич1 системи і развиток економжи Украши (матер1али економ1чного самм1ту) м. Луцьк, 2003. Асаул А. Н., Денисова И. В. Интеграция строительных фирм в форме сетевых индустриальных организаций Регион: политика, экономика, социология», №1, СПб., 2001. Асаул А. И., Иванов С. Н. Актуальность создания и эффективное управление корпоративными строительными структурами петербургского региона / Международная академия менеджмента. Научн. тр. Вып. IV. М., 2003. Май-зель А. И., Пивоваров И. С. и др. Предпринимательские структуры в рыночной экономике. - СПб.: СПбГУЭФ, 1995. Стаханов В. Н., Ивакин E. K. Маркетинг строительства: Учебное пособие для вузов. - М.: Приор, 2001. Толмачев Е. Л., 


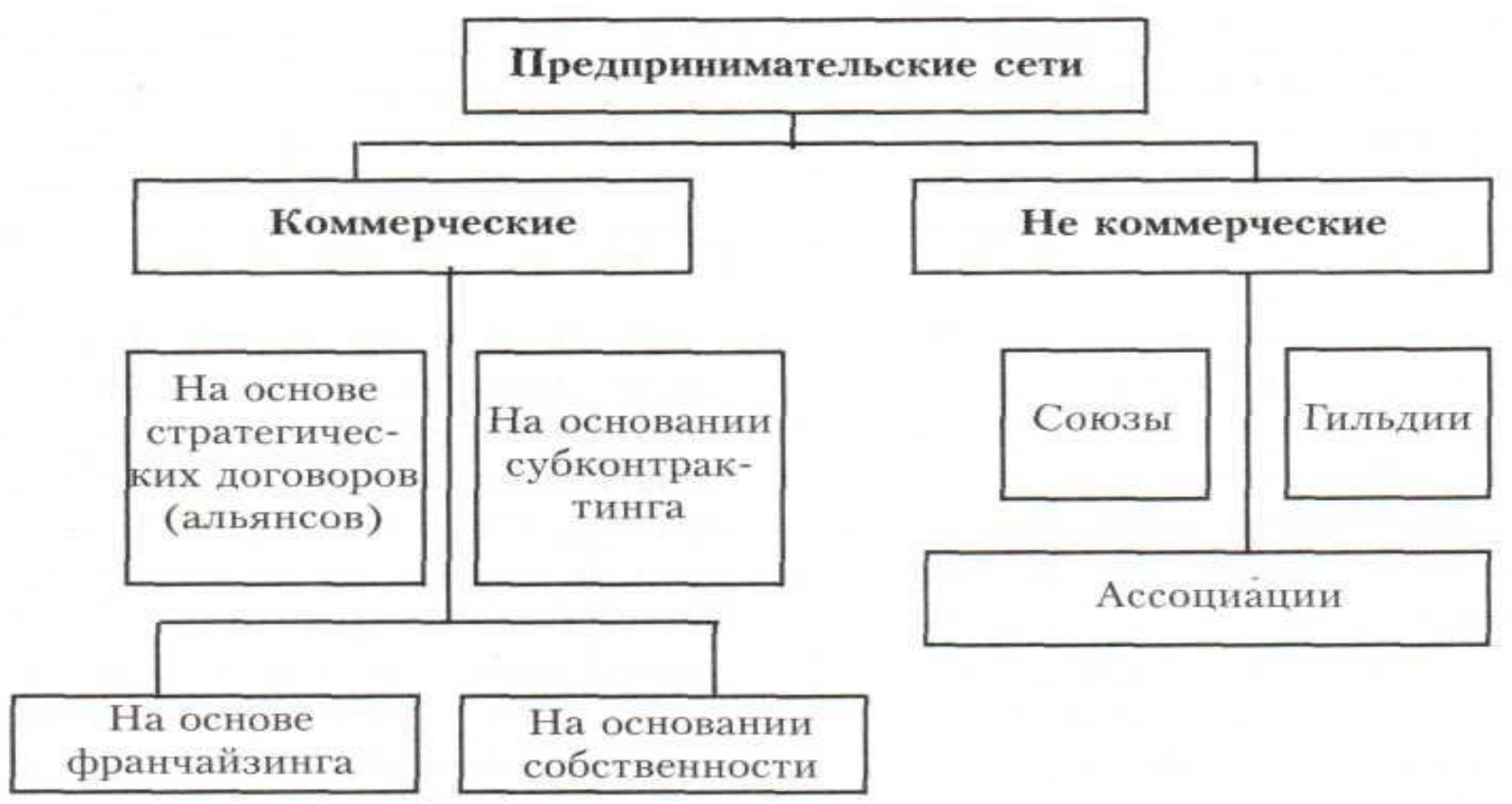

Рис. 3.5. Основные разновидности предпринимательской сети

Под сетевой организацией, как правило, понимается коалиция взаимозависимых специализированных экономических единиц со своими целями (независимые фирмы или автономные организации), которые действуют без иерархического контроля, однако все они задействованы в системе с общими целями, через многочисленные горизонтальные связи, взаимную зависимость и обмен. Далее делается вывод, что основным отличием сетевой теории от экономической теории организации является "вовлеченность". Кроме того, сетевая теория в меньшей степени содержит неоклассическую экономическую теорию, а в большей - социологические аспекты и политику коалиций. ${ }^{1}$

Содержательно сетевая концепция заключается в следующем:

рыночные субъекты развивают и поддерживают отношения друг с другом в целях получения дополнительных ресурсов;

совокупность рыночных субъектов, взаимодействующих длительное время, образует сеть заинтересованных в общих конечных результатах организаций;

развитие горизонтальных связей способствует укреплению отношений и определяет устойчивое положение партнеров в сети;

сетевые отношения позволяют фирмам снижать затраты на создание и реализацию инноваций.

Основными элементами сетевой теории являются субъекты рынка. Каждое предприятие представляет собой подсистему, в которой в зависимости от преследуемой цели и особенностей инновационной деятельности можно выделить функциональные подразделения, вступающие в контакт с другими подразделени-

Монахов Б. Е. Экономика строительства: Учебное пособие. - М.: ИД-Организация, 2003. Читипаховян П. Методологические проблемы стратегического планирования развития интегрированных корпоративных структур // Российский экономический журнал № 9, 2000.

${ }^{1}$ Подробнее см. Асаул А. И., Батрак А. В. Корпоративные структуры в региональном инвестиционном строительном комплексе / Монография. СПб.: Изд-во АСВ, СПбГАСУ, 2001. 
ЯМИ.

В рыночной экономике увеличивается динамизм развития социальноэкономических систем под влиянием конкуренций и требований научнотехнического прогресса. При этом проблема специализации отдельных бизнессубъектов и их кооперация приобретает новое звучание и большое значение.

Выбор партнеров по взаимодействию и формированию структуры предпринимательской сети обусловлено:

Задачами, проблемами, целями бизнес-субъектов,

Состоянием внешней среды, в которой функционирует взаимодействующие субъекты

Практика показывает, что существует проблема заключения сделок между хозяйственными субъектами.

Одним из существенных недостатков практики управления бизнес-субъектами заключается в том, что зачастую важные вопросы по их интеграции решаются интуитивно, без должной проработки, научного анализа и выбора наилучших решений.

Выбирая партнеров для разовых сделок, 1/3 от участвующих в опросе предпринимателей основывается на рекомендациях друзей и знакомых, около 6\% - на рекомендациях органов власти, около 10\% - на рекомендациях тех, кто обеспечивает безопасность предприятия ("крыш"). Для 53\% предпринимателей для совершения разовых сделок никакие рекомендации не нужны ${ }^{1}$.

При выборе партнеров для более длительных отношений предпринимательские структуры проявляют большую осторожность, учитывая в 35\% случаев рекомендации знакомых, в 10\% - рекомендации органов власти, в 18\% - рекомендации "крыш" и в 24\% - другие рекомендации. Не нуждаются ни в чьих рекомендациях при выборе постоянных партнеров 33\% от принявших участие в опросе предпринимателей (рис.3.6) .

С увеличением размера организации резко сокращается (с 50\% до 15\%) число считающих, что для заключения, как разовой сделки, так и установления долгосрочных контактов не нужны никакие рекомендации. При налаживании длительных отношений, с увеличением размера организации, снижается значение рекомендаций друзей и знакомых; при этом несколько растет значение рекомендаций органов власти и организаций, обеспечивающих безопасность предприятия.

Основным фактором, гарантирующим надежность связей с партнерами, является наличие формального договора и, соответственно, возможности обратиться в суд или арбитраж (65\% ответивших). Другими гарантиями выступают индивиды или организации, обеспечивающие безопасность предпринимательской структуры (15\% от числа ответивших), участие фирм в капитале друг друга (9\%), возможность вмешательства местных властей (6\%). Для 23\% респондентов такие гарантии не может дать никто и ничто. Заметим, что с ростом масштабов бизнесструктуры доля таких пессимистов падает (см. диаграмму).

На основе анализа места и роли предпринимательских сетей в системе предпринимательства можно сделать следующие основные выводы:

${ }^{1}$ Савицкая Г. В. Анализ хозяйственной деятельности предприятия: 4-е изд. перераб. и доп. - Минск: ООО «Новое знание», 2000. 
Эффективному развитию функционирования малого и среднего бизнеса способствует формирование предпринимательских сетей.

Существует устойчивая тенденция к активизации сетевых объединений, причем наиболее актуальными становятся именно предпринимательские сети, наиболее полно решающие задачи обеспечения рыночной адаптивности.

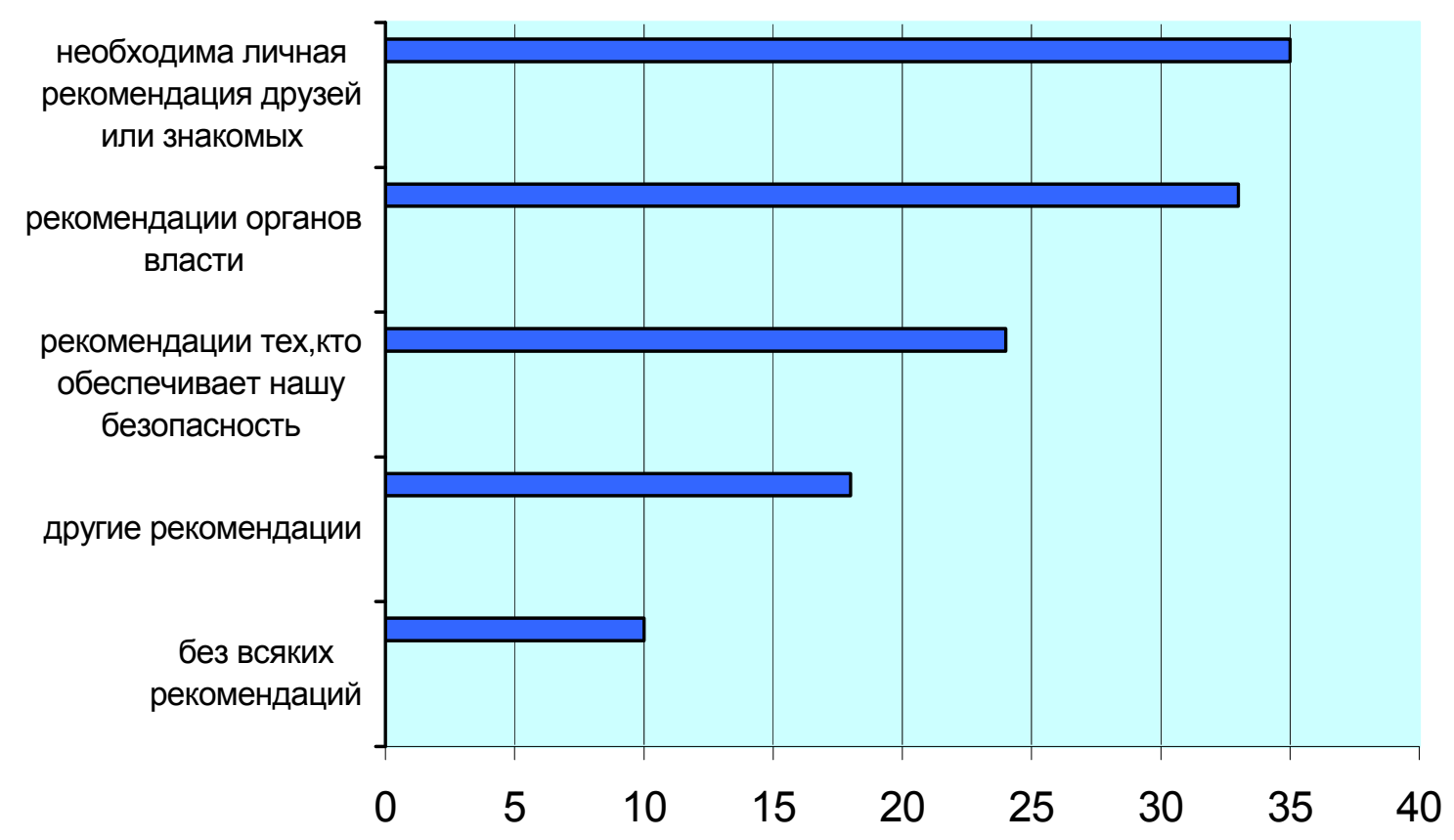

Рисунок 3.6 - Требуемые рекомендации при выборе постоянных параметров, в $\%$ от числа ответивших

Многовариантность управленческих решений при формировании предпринимательских сетей (подбора параметров, обоснование ее конфигурации, определении видов и форм специализации труда и т.д.) делает актуальным выбор наилучших с учетом параметров бизнеса и состояния и тенденции изменения внутренней и внешней среды.

\section{3 Исследование влияния факторов внешней и внутренней среды сете- вых объединений}

В неоклассической экономической теории процесс преобразования исходных ресурсов в готовый продукт осуществляла автономная юридически экономическая организация (предприятие). В современных условиях изменяется видение базовой модели предприятия. Она заменяется моделью кооперации и интеграции. Такая модель характеризуется тем, что в поведении предпринимательских объек- 
тов выявляется тенденция к кооперации производства и корпоратизации предприятий ${ }^{1}$ У Устойчивость этой тенденции позволяет утверждать, что важнейшими элементами рыночной экономики новейшего периода выступает совместное функционирование бизнес-единиц в рамках предпринимательских сетей. Исследуем факторы, вызывающие потребность и целесообразность их формирования.

Для изучения сложных объектов и проблем их функционирования и развития служит системный подход и системный анализ. Данный подход к исследованию объекта представляет собой конкретизацию материалистической теории познания и позволяет формализовать на определенных принципах процесс анализа, подготовки и обоснования путей решения выявленных проблем. Он позволяет лучше понять происходящие процессы функционирования бизнес-единиц и причины их вхождения в предпринимательские сети, дать их формализованное описание. Для регулирования процесса формирования и функционирования предпринимательских сетей необходим переход от частных эмпирических зависимостей и связей к созданию и формализации логического описания общей картины объекта во всей ее сложности и взаимообусловленности.

Системный подход позволяет проводить анализ всех совокупных факторов процесса и выявить их влияние в целом и его отдельных параметров на степень достижения поставленной цели. Состояние системы определяется свойствами основных ее элементов, ее возможностью функционировать для достижения поставленной цели в ответ на входной импульс.

Бизнес-единица представляет собой производственную систему:

- динамичной, так как ее состав и параметры, ее элементы (количество и их характеристики) меняются во времени;

- - искусственной, созданной людьми;

- открытой, связанной с внешней средой;

- стохастической, так как ее поведение можно предсказать с некоторой вероятностью.

Все объекты, явления, процессы, в том числе и протекающие в рамках социально-экономических систем различного уровня взаимосвязаны и влияют друг на друга, поэтому рассматривая бизнес-единицу необходимо учесть влияние среды на объект и объекта на среду. В общем виде функционирование бизнес-единицы можно представить в виде:

$$
\mathrm{P}_{\text {б.е. }}=\mathrm{F}\left(\mathrm{B}_{\text {б.е. }} ; \Pi_{\text {б.е. }}\right)
$$

где

$\mathrm{P}_{\text {б.е. }}-$ результат функционирования бизнес-единицы;

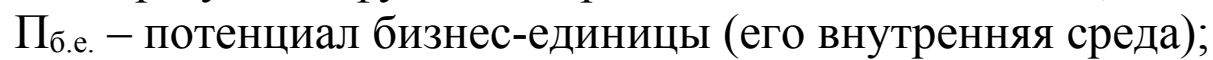

$\mathrm{B}_{\text {б.е. }}$ - состояние внешней среды, внешних условий ее функционирования.

Внешняя среда бизнес-единицы может характеризоваться двумя группами па-

${ }^{1}$ Авдавшева С.Б., Дементьев В. Акционерные и неимущественные механизмы интеграции в российских бизнес-группах // Российский экономический журнал №1, 2000. Асаул А.Н., Батрак А.В. Корпоративные структуры в региональном инвестиционно-строительном комплексе. СПб.: Изд-во АСВ, СПбГАСУ, 2001. 
раметров: параметрами микросреды, непосредственно влияющих на производственно-хозяйственную деятельность бизнес-единицы; параметрами макросреды, влияющих косвенно. Внешняя среда формирует входной импульс системы, воспринимает реакцию системы на входной импульс, воздействует на ее состояние. Внешняя среда, как известно, - это специфические, экономические, социальные условия и законы, нормы, правила, обычаи, потребности, возможности, определяющие предпринимательскую деятельность в данное время и в заданном месте. Она определяет условия предпринимательской деятельности и наличие необходимых для нее ресурсов: человеческих, материальных, информационных и т.д. ${ }^{2}$

Внешняя макросреда характеризуется следующими укрупненными группами элементов: социально-экономической политикой государства ( $\left.\mathrm{B}_{\text {с.э. }}\right)$; научнотехническим уровнем (достижения) ( $\left.\mathrm{B}_{\text {н.т. }}\right)$; демографической обстановкой $\left(\mathrm{B}_{\text {д. }}\right)$; уровнем нравственности и культуры $\left(\mathrm{B}_{\text {к.н. }}\right)$; уровнем общего и специального образования (Воб.).

Опыт становления рыночной экономики в России позволяет выявить следующие основные тенденции изменения факторов внешней среды предпринимательской деятельности:

- положительного изменения фактора (вр.д.) связаны с отработкой и дальнейшим совершенствованием законодательства, регулирующего предпринимательскую деятельность;

- положительного изменения фактора (вр.т.), связанного с увеличением (незначительным) платежеспособного спроса;

- отрицательной динамики фактора (в рентной среды, с ростом конкуренции;

- отрицательной тенденции изменения фактора состояния сырьевых ресурсов (вр.с.), связанное с увеличением их стоимости и стоимости их транспортировки;

- отрицательной тенденции изменения параметров рынка трудовых ресурсов (в.р.), связанное с ухудшением их качества и стоимости;

- положительной (на перспективу) тенденцией изменения рынка финансов (в.ф.), их большей доступностью и снижения стоимости кредита.

Внутренняя среда бизнес-единицы характеризуется параметрами состояния ее основных элементов, определяющих ее потенциал (Пб.е.), ее способность функционировать в определенных внешних условиях ${ }^{2}$ В качестве основных внутренних факторов бизнес-единицы рассматриваются:

- параметры продукции (товаров, работ, услуг) - Пт;

- параметры производства - Пп;

- параметры ресурсного обеспечения - Пр;

- параметры системы управления - Пу;

- параметры системы сбыта - Пс;

1 Завлин П.Н., Васильев А.В., Кноль А.И. Оценка экономической эффективности инвестиционных проектов. - СПБ.: Наука, 1995.

2 Завлин П. Н., Васильев А. В., Кноль А. И. Оценка экономической эффективности инвестиционных проектов. - СПб.: Наука, 1995. Казанский Ю. Н. Строительство в США и России: экономика, организация, управление. Научный центр корпорации «Двадцатый трест». - СПб.: «Двадцатый трест», 1995. 
- параметры, характеризующие финансовое положение -

Представленные в наборе параметры создают пространство состояния системы. Все параметры (факторы) находятся в определенной взаимозависимости. Рассмотрим, прежде всего, взаимосвязь параметров макро и микросреды, в которой функционирует бизнес-единица ${ }^{1}$.

Так, социально-экономическое положение страны $\left(\mathrm{B}_{\text {с.э. }}\right)$ в значительной степени определяет:

- принципы, методы, инструментарий регулирования предпринимательской деятельности, законы, нормы, правила, инструкции и т.д. (В.б.);

- величину и структуру платежеспособного спроса на продукцию системы предпринимательства ( $\left.\mathrm{B}_{\text {р.т. }}\right)$;

- возможности для развития предпринимательства, которые способствуют росту или сокращению количества бизнес-единиц;

- налоговую и таможенную политику в отношении сырьевых отраслей и соответственно влияет на количественные и ценовые параметры сырьевых рынков (топливо, металл, лес и т.д.) (Вр..);

- уровень занятости в стране, регионах, среди людей разных профессий; стоимость рабочей силы, т.е. ситуация на рынке трудовых ресурсов ( $\left.\mathrm{B}_{\text {т.p. }}\right)$;

- наличие финансовых ресурсов в стране и кредитную политику, т.е. состояние рынка финансов;

- ассигнование на развитие науки и техники, т.е. влияет на рынок научнотехнической продукции (новых технологий и т.д.) ( $\left.\mathrm{B}_{\text {н.т. }}\right)$.

Уровень научно-технического развития определяет:

- состояние рынка научно-технической продукции, наличие новых идей, технологий, разработок, товаров и т.д. (В

- возможности создания новых бизнес-единиц, базирующихся на реализации новых разработок и т.д. (Вк.с.).

Демографическая ситуация в стране $\left(\mathrm{B}_{\text {д. }}\right)$ влияет на:

- структуру платежеспособного спроса $\left(\mathrm{B}_{\text {р.т. }}\right)$, на состояние рынка трудовых ресурсов (B.p.).

Состояние нравственности и культуры общества $\left(\mathrm{B}_{\text {н.к. }}\right)$ : $\left(\mathrm{B}_{\text {T.p. }}\right)$.

- на метод регулирования бизнеса (В.б.), на состояние трудовых ресурсов

Направленность, структура, качество и стоимость образования (В на:

- состояние рынка трудовых ресурсов (В

Факторы внешней среды определенным образом влияют на параметры внутренней среды, определяющие потенциал предприятия:

- на финансовый потенциал бизнес-единицы (П

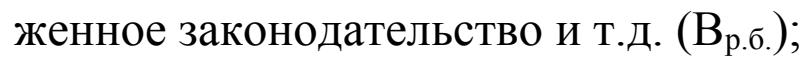

${ }^{1}$ Келлер $T$. Концепции холдинга: организационные структуры и управление. - Обнинск: ГЦПИК, 1998. Куприянова И. В., Михайлушкин А. И. Об особен ностях предпринимательской деятельности в строительстве. Экономическая политика в области жилищного строительства в условиях рыночных отношений. - СПб.: СПбГИЭА, 1994. Удалое В. П. Малый бизнес как экономическая необходимость: В 2 кн. - СПб.: Изд-во СПбГУЭФ, 2002. 
- на технологические возможности бизнес-единицы влияют состояние рынка научно-технической продукции $\left(\mathrm{B}_{\text {р.н.т. }}\right)$ и рынок финансов $\left(\mathrm{B}_{\text {р.ф. }}\right)$;

- на потенциал продукции $\left(\Pi_{\Pi}\right)$ влияет состояние рынка научно-технической продукции $\left(\mathrm{B}_{\text {р.н.т. }}\right)$; финансовые возможности $\left(\Pi_{\phi}\right)$; доступность сырья $\left(\mathrm{B}_{\text {p.c. }}\right)$; (B.p.);

- на кадровый потенциал предприятия (Пк) влияет рынок трудовых ресурсов

- на управленческий потенциал предприятия $\left(\Pi_{y}\right)$ влияет рынок трудовых ресурсов $\left(\mathrm{B}_{\text {т.р. }}\right)$ и рынок научно-технической продукции $\left(\mathrm{B}_{\text {р.н.т. }}\right)$.

Проведенный выше анализ показывает взаимосвязь и значительную взаимообусловленность факторов внешней и внутренней среды (рис. 3.7).

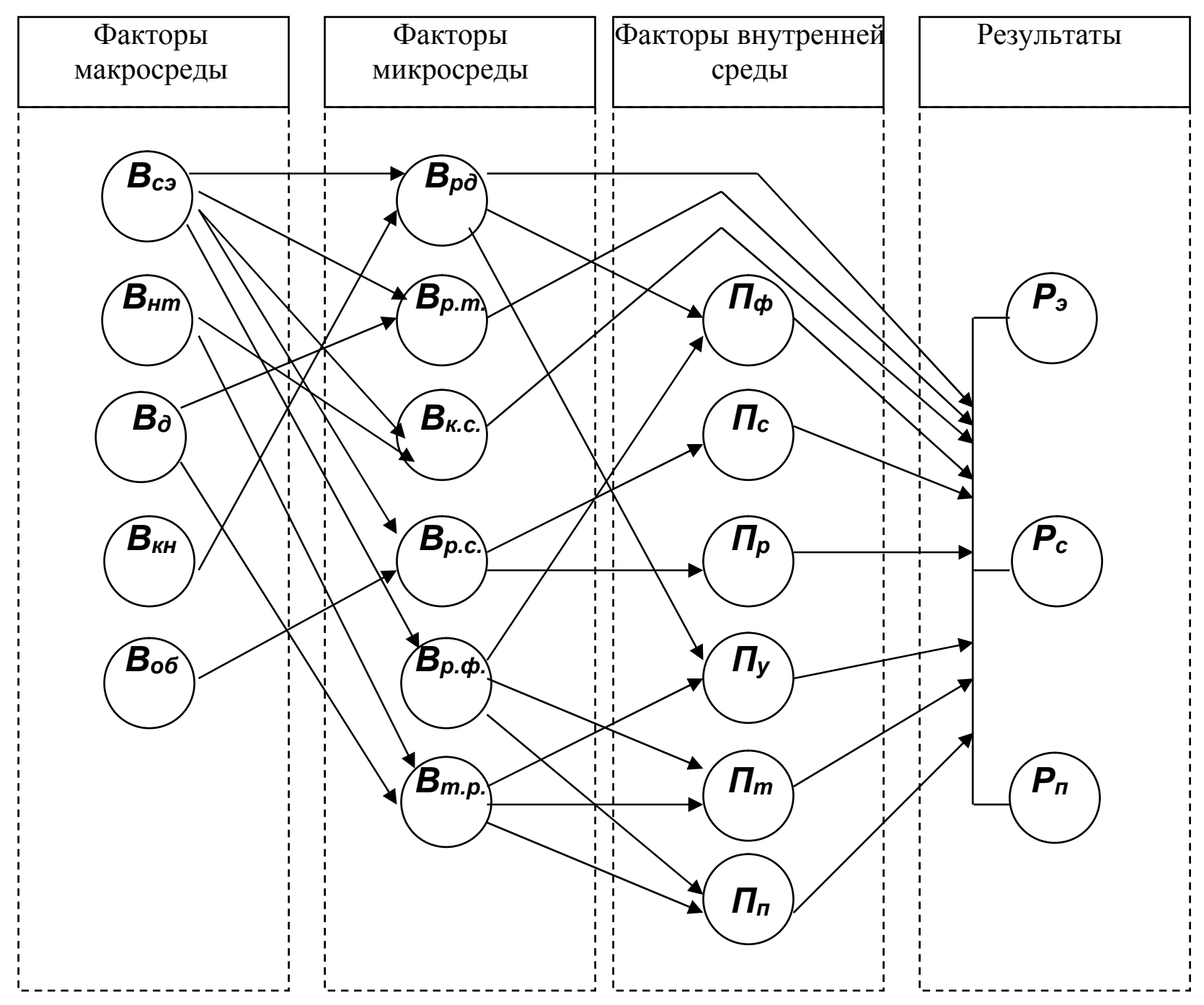

Рисунок .3.7. Взаимосвязь параметров внешней, внутренней среды и результатов функционирования бизнес-единицы

Для лучшего понимания проблем, стоящих перед бизнес-единицами, и определения путей их решения автором проведен анализ тенденции изменения пара- 
метров внешней и внутренней среды их функционирования ${ }^{1}$.

Анализ проводился на экспертной основе. В качестве экспертов выступали тридцать предпринимателей - менеджеров, которые ответили на вопросы специальной анкеты. Состояние отобранных выше факторов внешней среды оценивалось следующим образом:

- удовлетворяющие требованиям благоприятности бизнесу (У);

- не удовлетворяющие требованиям благоприятности бизнесу $(\mathrm{H})$.

Тенденции изменения факторов внешней среды оценивались:

- положительно для бизнеса (П);

- отрицательно для бизнеса (O);

- без изменений (стабильность) (C).

Изменения внешней макросреды обусловлены следующим:

- положительной тенденцией экономики государства $\left(\mathrm{B}_{\text {с.э. }}\right)$;

- положительным изменением научно-технической сферы;

- появлением новых научных разработок, новой технологии (НОУ-ХАУ);

- отрицательными тенденциями изменения демографической обстановки: уменьшением численности и старение населения;

- сохранением низкого уровня нравственности и культуры.

Результаты экспертного анализа тенденций изменения факторов внешней макро и микросреды бизнес-единиц приводится в табл.3.4.

Таблица 3.4 - Оценка (экспертное) состояния и тенденций изменения параметров внешней среды бизнес-единицы

\begin{tabular}{|c|c|c|c|}
\hline Факторы внешней среды & $\begin{array}{c}\text { Условное } \\
\text { обозначение }\end{array}$ & $\begin{array}{c}\text { Оценка } \\
\text { состояния }\end{array}$ & $\begin{array}{c}\text { Оценка тен- } \\
\text { денций измене- } \\
\text { ний }\end{array}$ \\
\hline $\begin{array}{c}\text { Социально-экономическое положение в } \\
\text { стране }\end{array}$ & $\mathrm{B}_{\text {с.э. }}$ & $\mathrm{y}$ & $\Pi$ \\
\hline Научно-технический уровень развития & $\mathrm{B}_{\text {н.т. }}$ & $\mathrm{y}$ & $\Pi$ \\
\hline Демографическая обстановка & $\mathrm{B}_{\text {д.о. }}$ & $\mathrm{H}$ & $\mathrm{O}$ \\
\hline Состояние нравственности и культуры & $\mathrm{B}_{\text {н.к. }}$ & $\mathrm{H}$ & $\mathrm{C}$ \\
\hline Законы, правила, нормы, регулирующие \\
бизнес & $\mathrm{B}_{\text {р.б. }}$ & $\mathrm{y}$ & $\Pi$ \\
\hline $\begin{array}{c}\text { Состояние рынка товаров и услуг (плате- } \\
\text { жеспособного спроса) }\end{array}$ & $\mathrm{B}_{\text {р.т. }}$ & $\mathrm{y}$ & $\Pi$ \\
\hline Состояние конкурентной среды & $\mathrm{B}_{\text {к.с. }}$ & $\mathrm{y}$ & $\mathrm{C}$ \\
\hline Состояние рынка трудовых ресурсов & $\mathrm{B}_{\text {т.р. }}$ & $\mathrm{y}$ & $\mathrm{C}$ \\
\hline Состояние рынка финансов & $\mathrm{B}_{\text {р.ф. }}$ & $\mathrm{H}$ & $\Pi$ \\
\hline Состояние рынка сырья & $\mathrm{B}_{\text {р.с. }}$ & $\mathrm{y}$ & $\mathrm{O}$ \\
\hline
\end{tabular}

Внутренние факторы связаны, прежде всего, со степенью прогрессивности продукции, состоянием техники, технологий; с квалификацией работников; с эффективным использованием основных средств производства и их соответствием

1 Читипаховян П. Методологические проблемы стратегического планирования развития интегрированных корпоративных структур // Российский эконо мический журнал №9, 2000. Экономико-математические методы и модели планирования и управления. - М.: Знание, 1993. 
научно-техническому уровню и т.д.

Экспертная оценка тенденций изменения факторов внутренней среды приводится в табл.3.5.

Воздействие внешних и внутренних факторов на функционирование бизнесединицы вызывает необходимость решения двух видов задач:

- повышение эффективности их текущей производственно-хозяйственной деятельности;

- обеспечение эффективности развития на определенную перспективу;

- снижение рисков (опасностей, угроз).

Под воздействием внутренних и внешних факторов возникают определенная дестабилизация, несоблюдение экономических принципов рациональной производственно-хозяйственной деятельности. В этой ситуации перед бизнес-единицей и ее руководством возникают проблемы (рис.3.8).

Таблица 3.5

Оценка (экспертная) тенденций изменения факторов внутренней среды бизнес-единицы

\begin{tabular}{|l|c|c|c|}
\hline Факторы & $\begin{array}{c}\text { Условное } \\
\text { обозначение }\end{array}$ & $\begin{array}{c}\text { Оценка } \\
\text { состояния }\end{array}$ & Тенденции \\
\hline $\begin{array}{l}\text { Потребительские свойства товара } \\
\text { (услуги) }\end{array}$ & $\Pi_{\text {п }}$ & Инд. & О \\
\hline Технологические возможности & $\Pi_{\mathrm{T}}$ & Инд. & $\mathrm{O}$ \\
\hline Кадровый потенциал & $\Pi_{\text {к }}$ & Инд. & Инд. \\
\hline Управленческий потенциал & $\Pi_{\mathrm{y}}$ & Инд. & Инд. \\
\hline Финансовый потенциал & $\Pi_{ф}$ & Инд. & Инд. \\
\hline
\end{tabular}

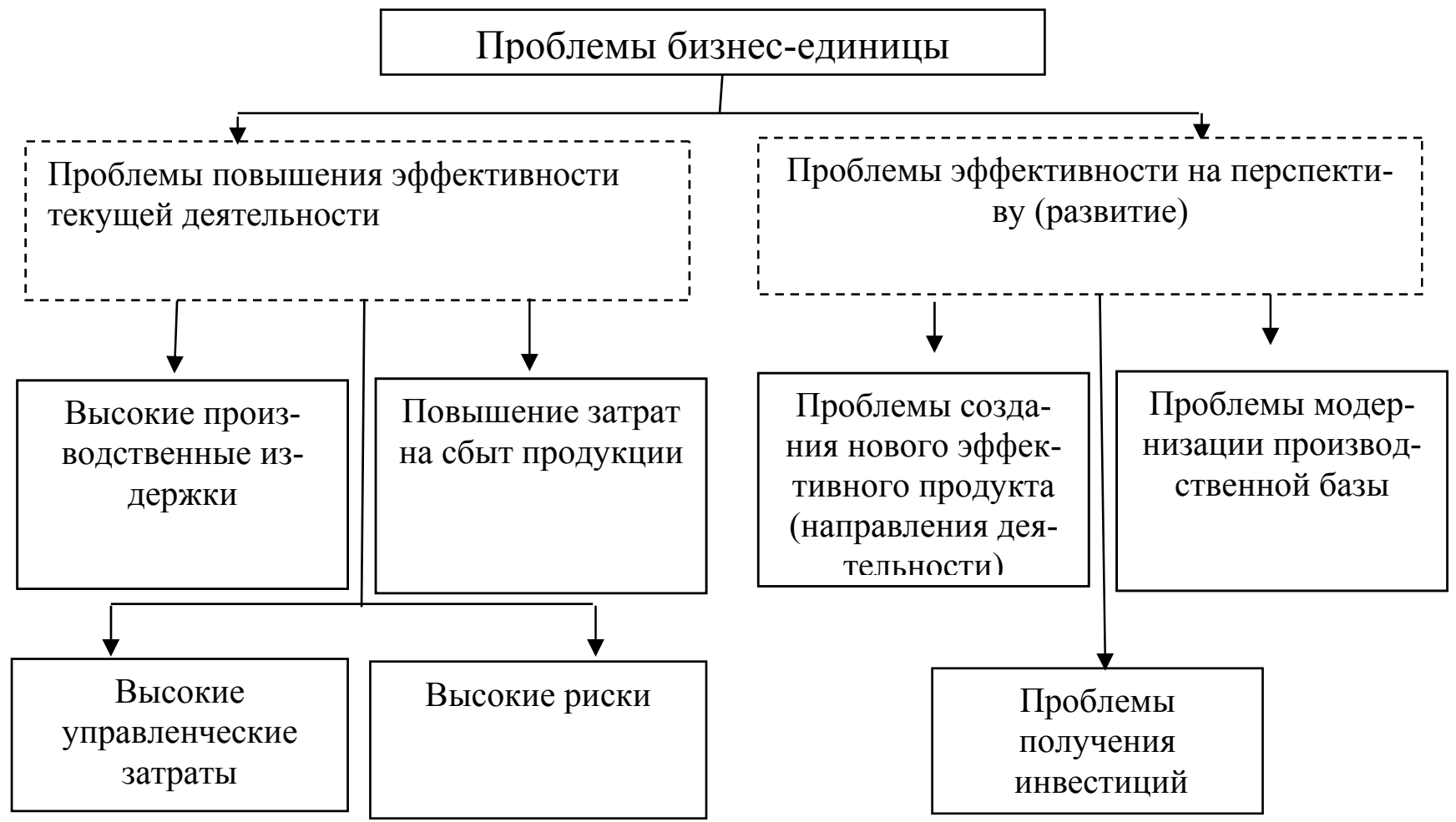

Рисунок 3.8. - Экономические проблемы бизнес-единицы 
В качестве основных методов снижения производственных издержек можно предложить:

- оптимизацию загрузки производственных мощностей (увеличение сменности, коэффициента загрузки и т.д., сокращения простоев оборудования);

- повышение производительности труда за счет внедрения рациональных трудовых приемов и ликвидации потерь рабочего времени;

- обеспечение оптимального использования всех производственных ресурсов (сырья, площадей, энергии);

- сокращение производственного цикла, незавершенного производства;

- оптимизацию складских запасов;

- повышение качества и сокращение брака.

Снижение управленческих расходов может быть достигнуто за счет:

- рационализации организационной структуры бизнес-единицы;

- рационального разделения и кооперации управленческого труда;

- оптимизации управленческого аппарата;

- автоматизации и компьютеризации управленческого труда

Возможности решения проблем бизнес-единиц за счет вхождения в предпринимательскую сеть рассмотрены в табл.3.6.

В процессе долгосрочного функционирования бизнес-единиц происходят различного рода изменения параметров организации и внешних условий его существования. Эти изменения происходят как стихийно, так и под регулирующим воздействием органов власти ${ }^{1}$.

Под воздействием внутренних и внешних факторов возникают определенные дестабилизации, несоблюдение экономических принципов рациональной производственно-хозяйственной деятельности. В этой ситуации перед бизнес-единицей и ее руководством возникают проблемы. Базовыми факторами их зарождения являются: развитие научно-технического прогресса общества, неравномерное развитие различных отраслей народного хозяйства, снижение нормы прибыли действующего традиционного производства, рост потребностей населения в новых, улучшенных товарах и услугах

Многие современные проблемы развития бизнес-единиц предприятий малого и среднего бизнеса могут успешно решаться за счет концентрации производства, углубления специализации и разделения труда ${ }^{2}$.

В качестве основных методов снижения производственных издержек можно предложить:

- оптимизацию загрузки производственных мощностей (увеличение сменности, коэффициента загрузки и т.д., сокращения простоев оборудования);

1 Уильямсон О. И. Экономические институты капитализма: фирмы, рынки, отношенческая конрактация. - СПб.: Лениздат, 1996. Экономико-математические методы и модели планирования и управления. - М.: Знание, 1993. Экономика предприятия и отрасли промышленности. Серия «Учебники, учебные пособия». - 3-е изд., перераб. и доп. - Ростов-на Дону: Феникс, 1999.

${ }^{2}$ Головина А. Н. Методология разработки проблемы специализации и кооперации, производства в условиях трансформируемой экономики // Известия Уральского университета, 1999. 
- повышение производительности труда за счет внедрения рациональных трудовых приемов и ликвидации потерь рабочего времени;

- обеспечение оптимального использования всех производственных ресурсов (сырья, площадей, энергии);

- сокращение производственного цикла, незавершенного производства;

- оптимизацию складских запасов;

повышение качества и сокращение брака.

Снижение управленческих расходов может быть достигнуто за счет:

- рационализации организационной структуры бизнес-единицы;

- рационального разделения и кооперации управленческого труда;

- оптимизации управленческого аппарата;

- автоматизации и компьютеризации управленческого труда.

Вхождение бизнес-единицы в предпринимательскую сеть позволяет оптимизировать экономический потенциал всех участников предпринимательской сети, получить синергетический эффект от объединения их ресурсов. Вхождение бизнес-единицы в предпринимательскую сеть переносит конкуренцию межфирменную в конкуренцию объединений (сетей).

Таблица 3.6 - Возможности решения проблем бизнеса за счет вхождения в предпринимательскую сеть

\begin{tabular}{|c|c|c|}
\hline № & Задачи & Пути решения \\
\hline 1 & 2 & 3 \\
\hline \multicolumn{3}{|c|}{ 1. Проблемы повышения эффективности функционирования бизнес-единиц } \\
\hline 1.1 & $\begin{array}{l}\text { Снижение производ- } \\
\text { ственных издержек }\end{array}$ & $\begin{array}{l}\text { - Оптимизация технических возможностей }\left(\Pi_{\mathrm{T}}\right) \text { на основе } \\
\text { производственной кооперации; } \\
\text { - Увеличение кадрового потенциала }\left(\Pi_{\mathrm{\kappa}}\right) \text { и рост произво- } \\
\text { дительности труда за счет углубления специализации произ- } \\
\text { водства; } \\
\text { - Увеличение финансового потенциала }\left(\Pi_{\phi}\right) \text { за счет до- } \\
\text { ступа к финансовым ресурсам партнеров; } \\
\text { - Увеличение конкурентоспособности продукции (цены) } \\
\text { за счет ее модернизации при участии партнеров, осуществ- } \\
\text { ляющих НИР и ОКР. }\end{array}$ \\
\hline 1.2 & $\begin{array}{l}\text { Повышение качества } \\
\text { управления }\end{array}$ & $\begin{array}{l}\text { - За счет разработки и реализации совместной стратегии с } \\
\text { партнерами; } \\
\text { - За счет централизации отдельных управленческих функ- } \\
\text { ций (информационных, бухгалтерских, маркетинговых и др.) }\end{array}$ \\
\hline 1.3 & $\begin{array}{l}\text { Повышение эффектив- } \\
\text { ности сбыта продукции }\end{array}$ & $\begin{array}{l}\text { - За счет вхождения в предпринимательскую сеть сбыто- } \\
\text { вых организаций; } \\
\text { - За счет оптимизации сбытовой сети; } \\
\text { - За счет кооперации и концентрации сбытовых процессов } \\
\text { в рамках предпринимательской сети. }\end{array}$ \\
\hline 1.4 & Снижение рисков & $\begin{array}{l}\text { - При закупке сырья, материалов и комплектующих; } \\
\text { - При проведении сбытовых операций. }\end{array}$ \\
\hline \multicolumn{3}{|c|}{ 2. Проблемы эффективного развития бизнес-единицы } \\
\hline 2.1 & $\begin{array}{l}\text { Создание нового про- } \\
\text { дукта (новых направле- } \\
\text { ний деятельности) }\end{array}$ & $\begin{array}{l}\text { - За счет налаживания партнерских отношений с крупны- } \\
\text { ми предприятиями, имеющими подразделения НИР и ОКР; } \\
\text { - За счет налаживания партнерских отношений с иннова- } \\
\text { ционными организациями; }\end{array}$ \\
\hline
\end{tabular}




\begin{tabular}{|c|c|c|}
\hline & & $\begin{array}{l}\text { - За счет привлечения инвестиций партнеров по предпри- } \\
\text { нимательской сети. }\end{array}$ \\
\hline 2.2 & $\begin{array}{l}\text { Модернизация произ- } \\
\text { водственной базы }\end{array}$ & $\begin{array}{l}\text { - За счет производственной кооперации; } \\
\text { - За счет привлечения инновационных организаций (НИИ, } \\
\text { КБ, ПБ); } \\
\text { - За счет привлечения инвестиций партнеров и совмест- } \\
\text { ного финансирования. }\end{array}$ \\
\hline 2.3 & $\begin{array}{l}\text { Модернизация, развитие } \\
\text { системы сервиса и сбыта }\end{array}$ & $\begin{array}{l}\text { - За счет создания объединений, разветвленной системы } \\
\text { сервиса и сбыта на основе объединения и оптимизации соот- } \\
\text { ветствующих ресурсов партнеров. }\end{array}$ \\
\hline
\end{tabular}

Ряд фирм участвуют в межфирменных союзах для того, чтобы лишить конкурента доступа к ресурсам и создать препятствия для третьей фирмы. При этом необходимо учитывать, что межфирменное сотрудничество целесообразно лишь при сохранении контроля за собственным бизнесом, иначе бизнес-единица может оказаться в ситуации игнорирования ее интересов ради другого (их) участников предпринимательской сети ${ }^{1}$.

В современных условиях формируются институты, определяющие базовые свойства и правила взаимоотношений субъектов рыночной экономики ${ }^{2}$.

Одним из основных интегрирующих элементов выступает договор, который юридически обеспечивает выполнение взаимных обязательств в процессе разработки производства и сбыта товаров и услуг.

Предприятие в институциональном аспекте может рассматриваться как целостный экономический субъект, интегрирующий разнообразные социальноэкономические процессы с целью обеспечения своего эффективного стабильного развития.

Таким образом, основными предпосылками для вхождения бизнес-единицы в предпринимательскую сеть является наличие проблем, которые наиболее эффективно решаются совместно сетевыми партнерами.

\section{4. Процессы формирования и функционирования предпринимательских сетей}

Предпринимательская сеть представляет собой комплекс бизнес - единиц (сетевых партнеров), которые функционируют самостоятельно в режиме взаимодействия со своими сетевыми партнерами. Они осуществляют свою производственно - хозяйственную деятельность с определенной степенью согласованности, вырабатывая тактические и стратегические управленческие решения, общие для всех участников предпринимательской сети. Таким образом она (сеть) выступает как объект управления.

${ }^{1}$ Асаул А. Н., Батрак А. В. Корпоративные структуры в региональном инвестиционностроительном комплексе.- СПб.: Изд-во АСВ, СПбГАСУ, 2001.

2 Головина A. H. Методология разработки проблемы специализации и кооперации, производства в условиях трансформируемой экономики // Известия Уральского университета, 1999. 
Общая схема классификации объединений, функционирующих в современной экономике России представлена в приложении Е.

Под данное выше базовое определение подходит целый класс объектов, имеющих общие основные признаки и в то же время обладающих своими характерными особенностями. Общие характеристики сетевых организаций приводятся в приложении Ж. Для более полного понимания процессов формирования и функционирования предпринимательских сетей необходимо учитывать их типологические особенности.

Наиболее часто при классификации корпоративных структур (наиболее близких к предпринимательской сети) используют в качестве базовых классификационных признаков: степень имущественного контроля внутри группы; организационно - правовую форму участников; жесткость взаимосвязей ${ }^{1}[1,7,25]$.

Этот подход не отражает особенности предпринимательских сетей, сохраняющих, как правило, организационно - правовые формы сетевых партнеров и не исчерпывает их все разновидности.

Задачи, которые ставят бизнес - единицы при их вхождении в предпринимательскую сеть, могут быть следующими: выживание, увеличение прибыли, дальнейшее развитие.

Задачу выживания ставит перед собой бизнес - единица при неблагоприятных изменениях факторов внешней или внутренней среды. В этом случае вхождение бизнес - единицы в предпринимательскую сеть должно позволить либо избежать, либо минимизировать грядущие потери.

Задача увеличения прибыли связана со снижением производственных и закупочно-сбытовых издержек или с увеличением производства и продаж продукции бизнес- единицы.

Задача дальнейшего развития связана с выбором эффективных стратегий бизнеса, проектированием нового продукта или разработкой новых направлений деятельности и созданием базы для его реализации.

Формирование предпринимательской сети актуально для бизнес - единиц любых отраслей, осуществляющих любые виды деятельности. В то же время отраслевая специализация определяет своеобразие потребностей и возможностей во взаимодействии соответствующих предприятий и организаций. Бизнес - единицы в процессе взаимодействия осуществляют различные виды и методы кооперации ради достижения поставленных целей.

Все многообразие предпринимательских сетей различается: по цели их создания; по отраслевой принадлежности (специализации бизнес - единиц, выпускаемой продукции); по направлениям взаимодействия (кооперации); по степени взаимодействия в капиталах сетевых партнеров; по количеству участников; по территориальному размещению; по уровню корпоративного управления.

${ }^{1}$ Авдашева С. Б. Хозяйственные связи в российской промышленности: проблемы и тенденции последнего десятилетия. - М.: ГУ-ВШЭ, 2000. Асаул А. Н., Батрак А. В. Корпоративные структуры в региональном инвестиционно-строительном комплексе. - СПб.: Изд-во АСВ, СПбГАСУ, 2001. Джордж Т. М., Тис Д. Д. Конкуренция и кооперация в стратегии американских корпораций. Джордж Т.М., Тис Д.Д. Конкуренция и кооперация в стратегии американских корпораций.- В кн.: У роки организации бизнеса // Сост. Демин А. А., Катькало В. С. - СПб.: Лениздат, 1994. 
Классификационные признаки предпринимательских сетей приводятся на рис.3.9.

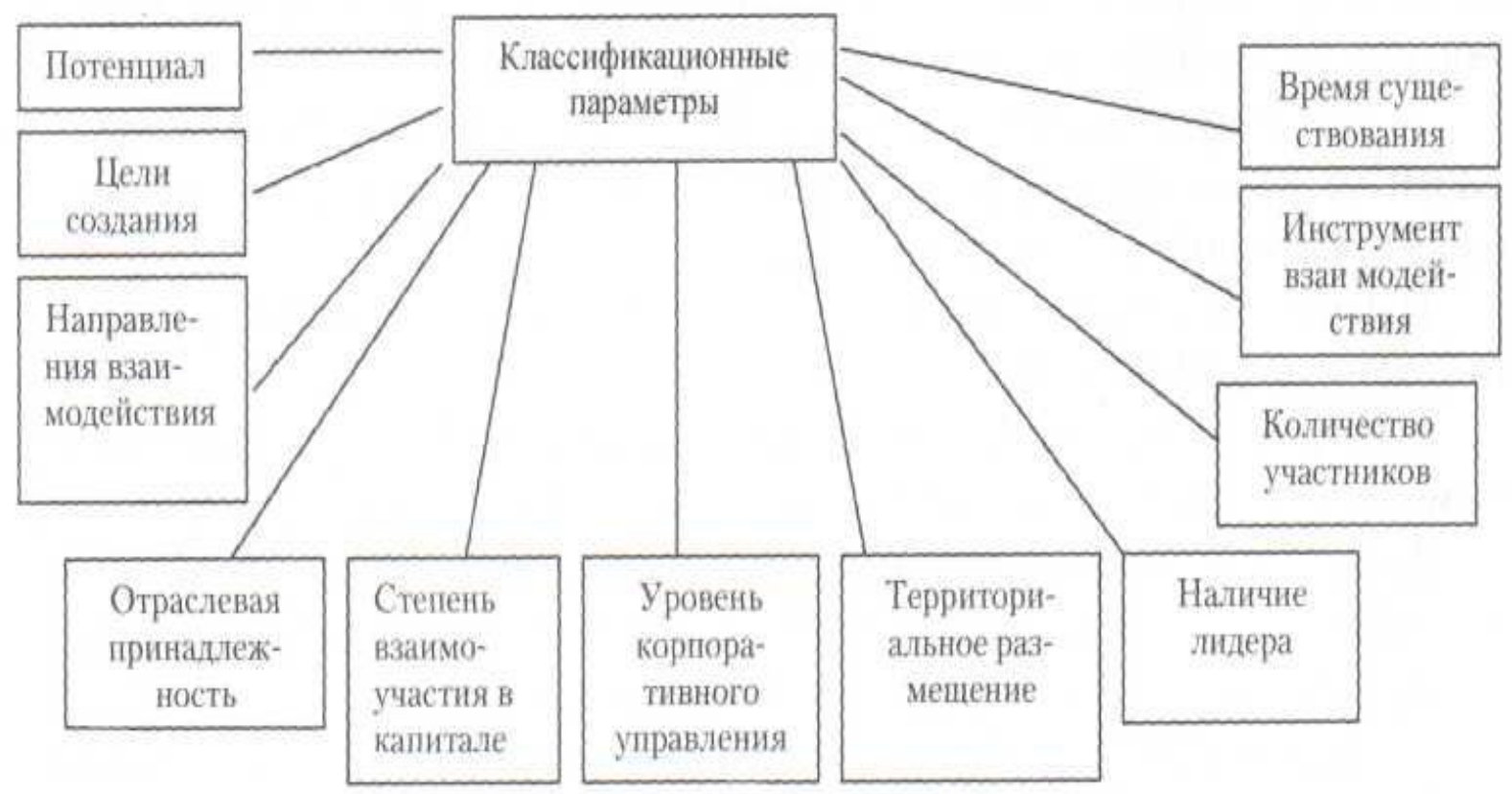

Рисунок 3.9. -. Классификационные признаки предпринимательских сетей

Развернутая типология предпринимательских сетей имеет следующий вид:

1. По целям создания можно выделить следующие разновидности: направленные на повышение эффективности производства сетевых партнеров, направленные на повышение эффективности сбыта, направленные на повышение эффективности ресурсного обеспечения, направленные на повышение эффективности управления, направленные на повышение эффективности НИР и ОКР, направленные на получение дополнительных финансовых ресурсов (доступ к инвестициям), направленные на снижение рисков, опасностей, угроз, направленные на усиление конкурентных позиций; направленные на усиление безопасности предпринимателя и бизнеса, направленные на достижение нескольких выше названных целей.

2. По отраслевой принадлежности можно выделить следующие разновидности: предпринимательские сети в промышленности, строительстве, других отраслях.

3. По направлениям взаимодействия сетевых партнеров можно выделить следующие разновидности сети: производственно - кооперированные, ресурсно кооперированные, сбытово - кооперированные, управленческо - кооперированные, кооперированные в сфере НИОКРа, финансово - кооперированные, комплексно - кооперированные.

4. По степени взаимоучастия в капиталах сетевых партнеров: с автономным капиталом, без его консолидации; с частным объединением активов отдельных участников; с владением материнской компанией контрольного, блокирующего или полного пакетов акций других участников.

5. По уровню корпоративного управления: сети, в которых сетевые партнеры согласуют элементы, разделы своих планов, имеющих взаимный интерес; сети, в которых сетевые партнеры отдельные функции (элементы) управления интегри- 
руют на договорной основе; сети, в которых сетевые партнеры совместно реализуют корпоративную программу с помощью определенных централизованных органов управления.

6. По количеству участников: малые предпринимательские сети (две - три предпринимательские единицы); средние предпринимательские сети (до десяти предпринимательских единиц); крупные (свыше десяти предпринимательских единиц).

7 По территориальному размещению: в одном городе (области); в одном регионе; межрегиональные; национальные; межнациональные.

8 По наличию лидирующего предприятия: имеющие примерно равный вес и финансово--производственные возможности.имеющие материнское предприятие, контролирующее деятельность "дочек". имеющие в качестве лидера предприятие (организацию), для нужд которой функционируют прочие участники сети.

9 По потенциалу (производственным, финансовым возможностям) могут быть выделены предпринимательские сети: мелкие, средние и крупные (монополисты).

10. По времени существования: образующиеся для решения разовых задач на непродолжительное время (эпизодические); для решения текущих проблем, для решения стратегических задач (долгосрочный период).

11. По инструменту интеграции: бизнес - единицы взаимодействуют на основе заключенных между ними контрактов; на основе стратегических договоров; на основе целевых программ.

Параметры предпринимательской сети должны отвечать следующим требованиям эффективности:

1. Целевая направленность предпринимательской сети должна соответствовать или сочетаться с целями бизнес - единиц, сетевых партнеров.

2. Отраслевая принадлежность предпринимательской сети определяется специализацией входящих в нее бизнес - единиц и должна соответствовать целям и задачам входящих в нее сетевых партнеров.

3. Направление взаимодействия сетевых партнеров должно обеспечивать вид и глубину кооперации, необходимой для достижения целей вхождения бизнес единиц в сеть.

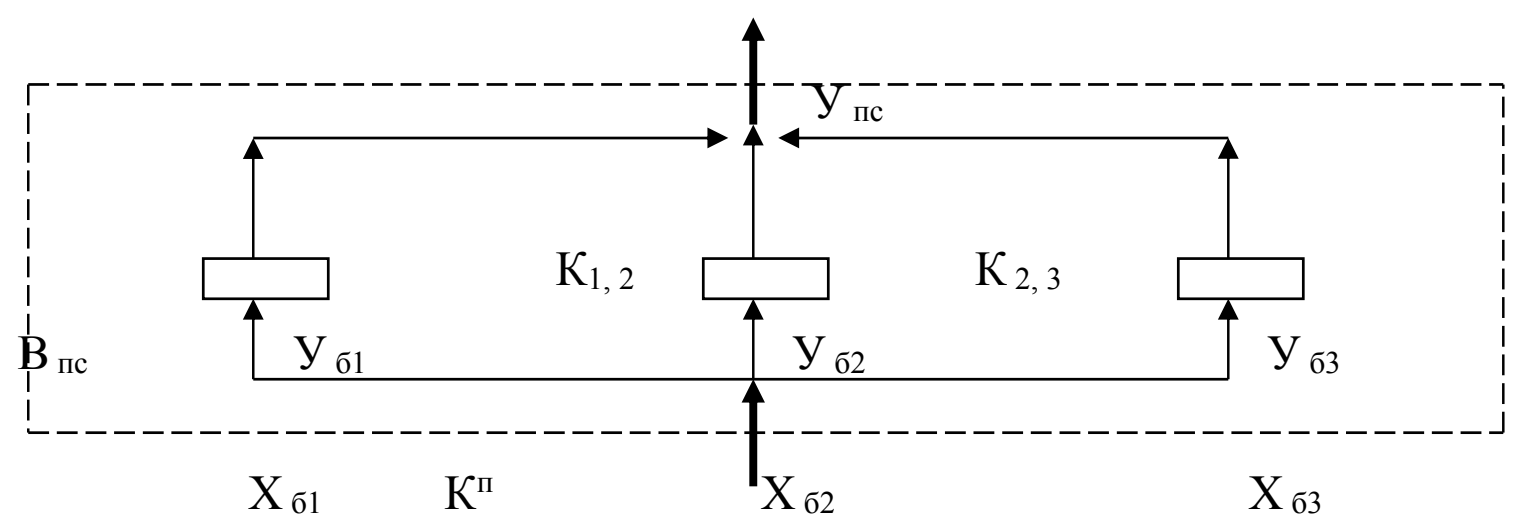

1-й вариант: закупочно-сбытовая (реализационная) кооперация 


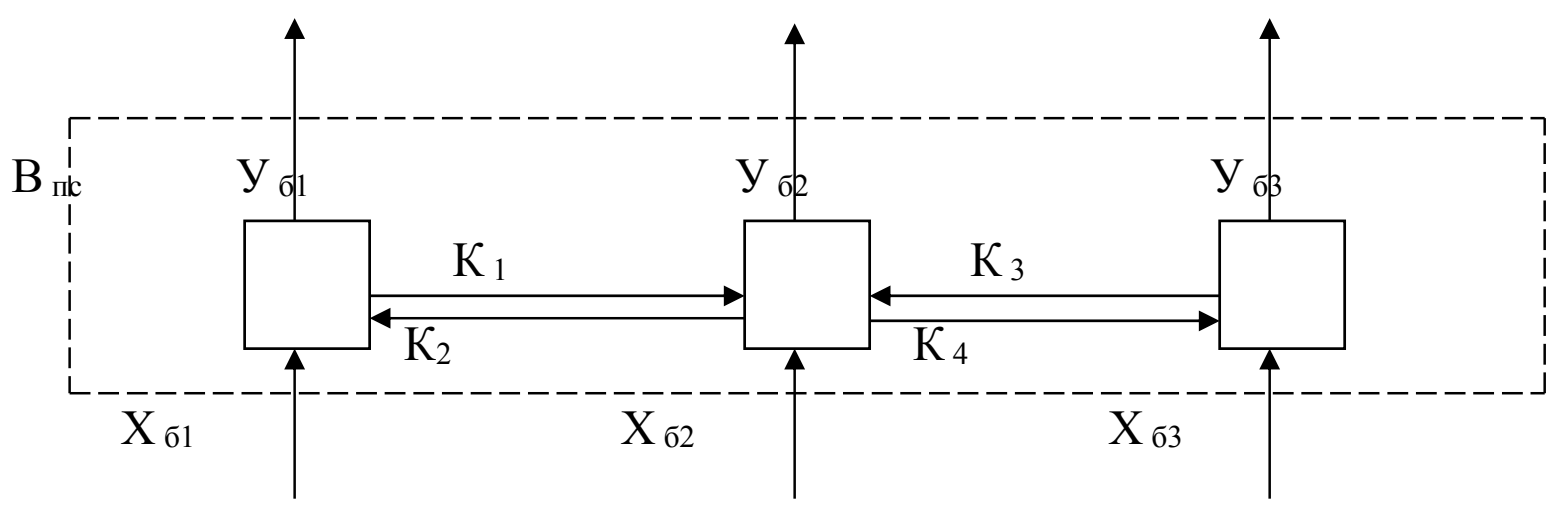

2-й вариант: производственная промежуточная кооперация

Рисунок 3.10 -. Модели функционирования предпринимательских сетей разной формы кооперации (1-й и 2-й вариант)

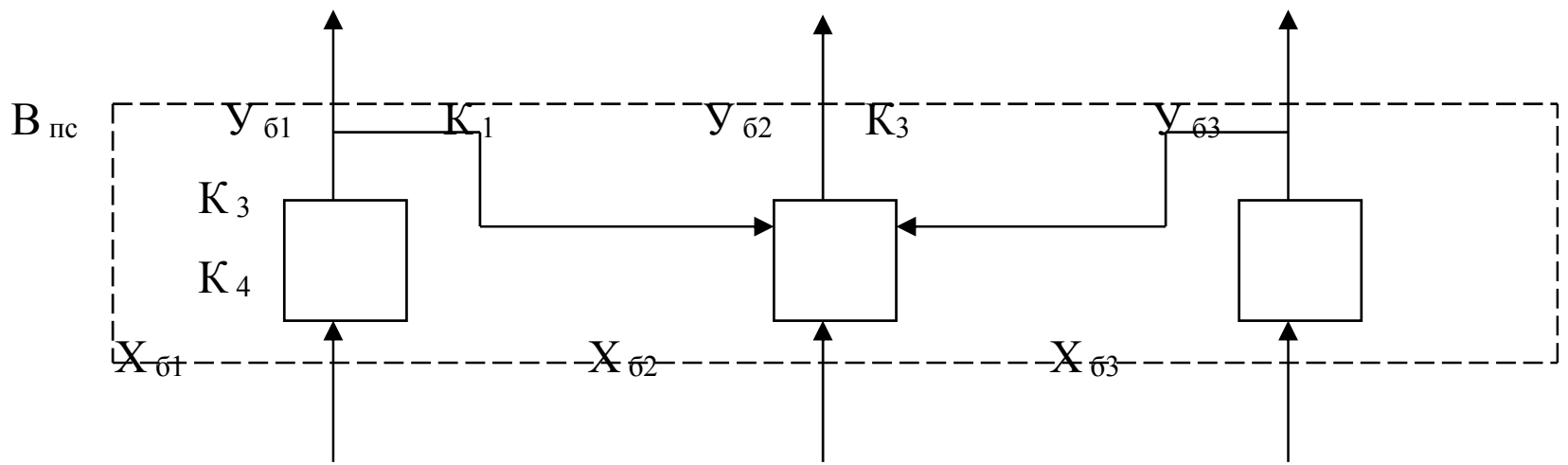

3-й вариант: смешанная производственная кооперация

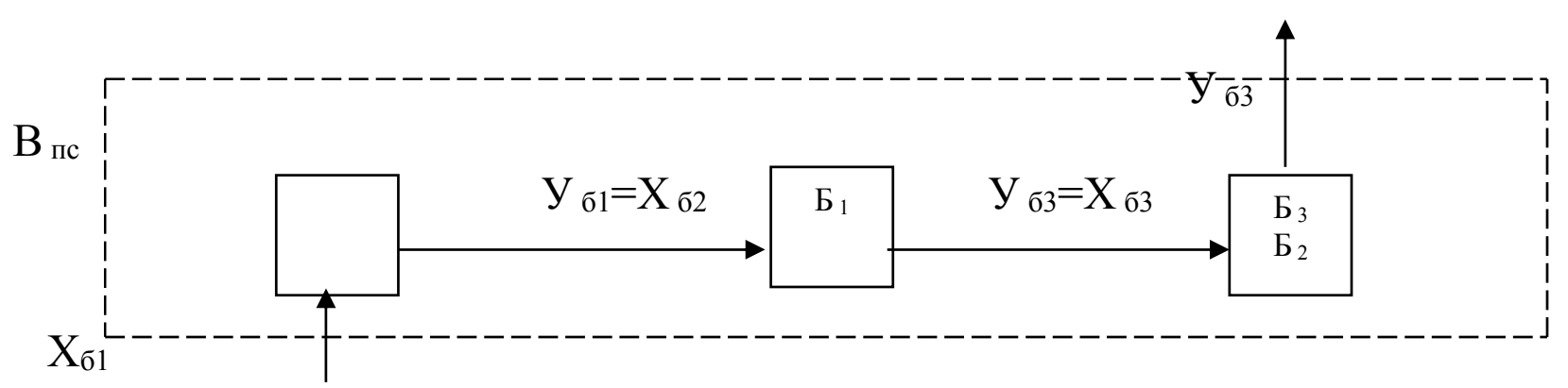

5-й вариант: специализация бизнес-единиц по отдельным стадиям производственного процесса

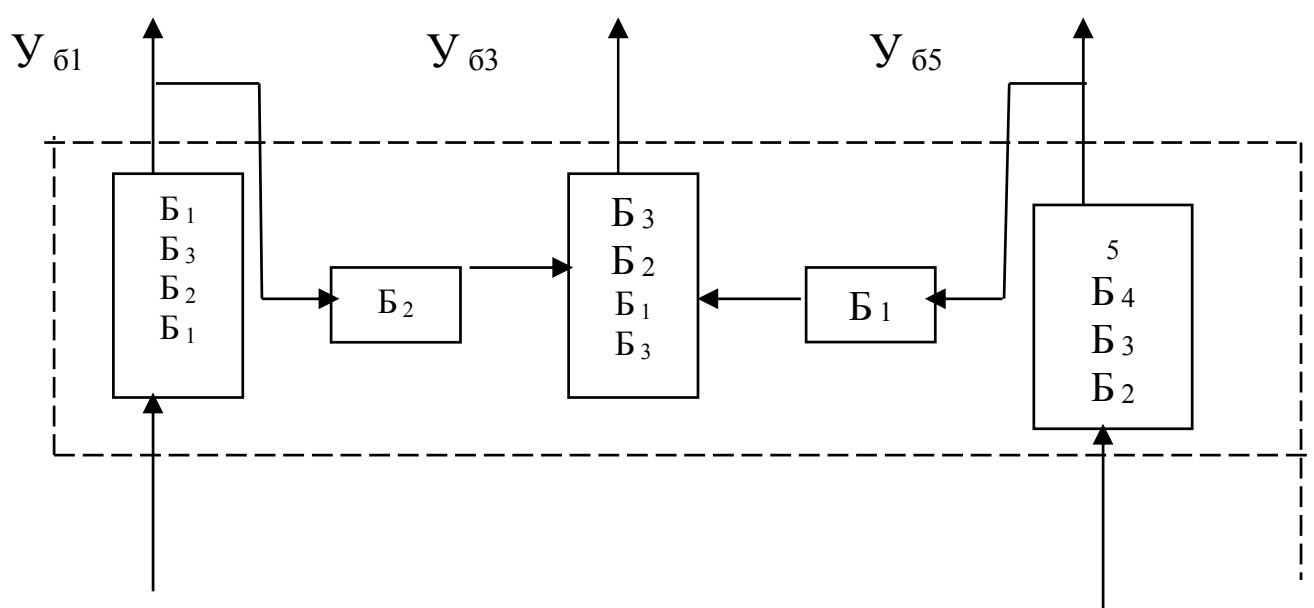


5-й вариант: часть продукции бизнес-единиц Б1 и Б2 является комплектующими изделиями - модель комплектации

Рисунок 3.11 -. Модели функционирования предпринимательских сетей

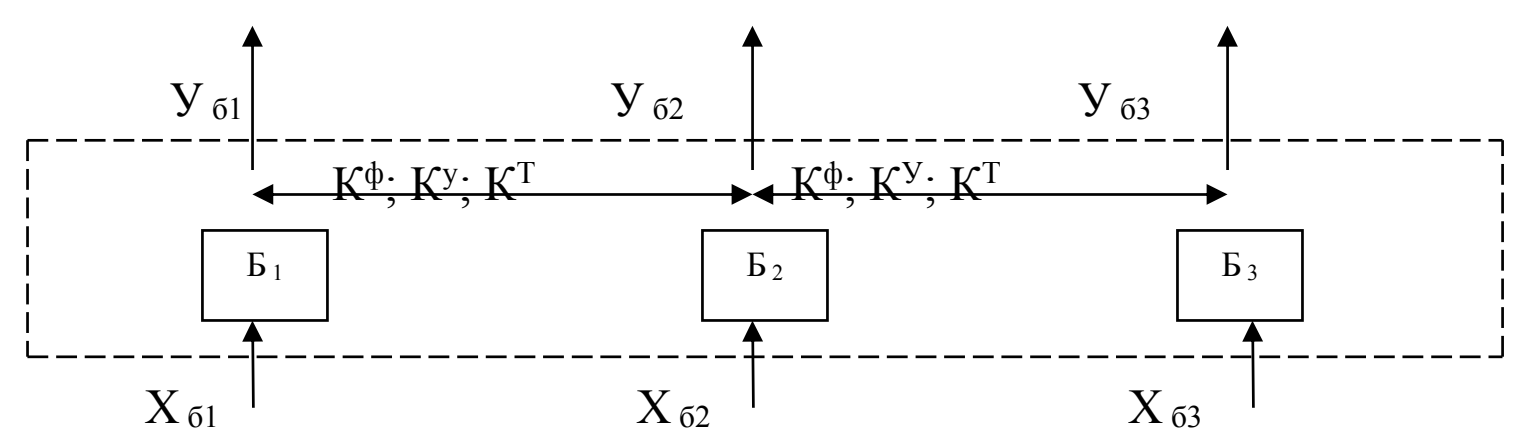

6-ой вариант: кооперация в области финансов, управления и создания нового товара

Рисунок 3.12 -. Модели функционирования предпринимательских сетей (6-й вариант)

4. Степень взаимоучастия в капиталах участников связана с личностной стратегией собственника. Высокая степень взаимоучастия снижает свободу действий сетевых партнеров, частичное взаимоучастие способствует их сплочению. В условиях совместной реализации многочисленных сложных проектов, на которых в значительной степени замкнута вся деятельность сетевых партнеров взаимоучастие в их капиталах представляется целесообразным.

5.Количество сетевых партнеров должно быть:

достаточным для решения их проблем на основе максимальной кооперации их возможностей;

ограниченым по возможностям эффективной координации их деятельности и управления без создания специальных структур.

6. Состояние и величина потенциала предпринимательской сети определяется локальными потенциалами сетевых партнеров и условий их кооперации. Они должны обеспечивать достижение поставленных целей.

7.Территориальное размещение предпринимательской сети должно обеспечивать:

- управляемость или скоординированность;

- допустимые по затратам и надежности транспортные потоки;

- благоприятность внешней среды.

Процесс формирования предпринимательских сетей включает комплекс управленческих решений и действий по их реализации, в результате которого несколько бизнес - единиц начинают функционировать как сетевые партнеры. 
Процесс формирования предпринимательской сети включает следующие основные стадии:

1.Выявление проблем бизнес - единицы и создание возможностей их решения в рамках сетевого партнерства.

2.Формулировка целей вхождения в предпринимательскую сеть.

3.Подбор сетевых партнеров (или предпринимательской сети): цели которых сочетаемы или адекватны; параметры которых обеспечивают эффективную кооперацию и взаимодействие бизнес - единиц.

4.Обоснование структуры формируемой предпринимательской сети и методов взаимодействия, выработки и реализации общих управленческих решений (управления и кооперации).

Процесс функционирования предпринимательской сети включает:

- локальные процессы функционирования сетевых партнеров;

- объединение процессов взаимодействующих сетевых партнеров.

Локальные процессы осуществляются бизнес - единицами самостоятельно, с использованием своего потенциала.

Объединенные процессы взаимодействия сетевых партнеров осуществляются в их интересах, включают формирование и реализацию информационных и материальных потоков между ними, т. е. их координацию в пространстве и времени.

Проанализируем процессы функционирования предпринимательских сетей. В зависимости от направления взаимодействия (кооперации) они имеют свои особенности.

При рассмотрении вариантов использовались следующие условные обозначения:

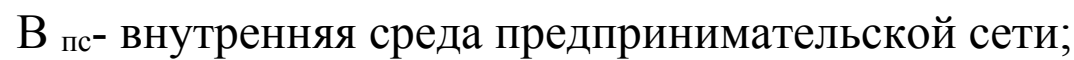

$Б_{1}, Б_{2}, Б_{3}-$ бизнес - единицы, входящие в предпринимательскую сеть;

$\mathrm{X}_{\text {пс }}$ - вектор, характеризирующий производственное сырье (ресурсы) используемое для изготовления продукции предприятий, участников предпринимательской сети;

$\mathrm{y}_{\text {пс }}$ - вектор, характеризирующий продукцию предприятий, входящих в предпринимательскую сеть;

$\mathrm{X}_{61} ; \mathrm{X}_{62} ; \mathrm{X}_{63}$ - векторы, характеризующие сырье (материалы) соответственно бизнес - единиц Б 1, Б $_{2}, Б_{3}$;

$\mathrm{Y}_{\text {б1 }} ; \mathrm{У}_{\text {б2}} ; \mathrm{У}_{63}$ - векторы, характеризующие продукцию соответственно бизнес - единиц Б 1, Б$_{2}, Б_{3}$;

$\mathrm{K}_{1}, \mathrm{~K}_{2}, \mathrm{~K}_{3}$ - кооперационная связь соответствующих бизнес - единиц,

$\mathrm{K}^{\Phi}, \mathrm{K}^{\mathrm{y}}, \mathrm{K}^{\mathrm{T}}$ - кооперационные связи в области финансов, управления и создания новых видов продукции или развития новых направлений деятельности.

В самом общем виде с позиции кибернетики процесс функционирования предпринимательской сети можно представить в виде "черного ящика", "на входе" которого поступают сырьевые материалы (или импульс к действию), на "выходе" готовая продукция (работы, услуги) - результат действия.

Конфигурация сети характеризует направление материальных и информационных потоков во взаимодействующих элементах (бизнес - субъектов) предпринимательской сети. 
Первый вариант предпринимательской сети характеризуется взаимодействием бизнес - единиц при решении задач:

- обеспечение сырьем, необходимым для изготовления продукции;

- реализации готовой продукции.

Возможны случаи, когда данный вариант осуществляется более ограничено, и решается только одна из рассмотренных выше задач.

Условием эффективности функционирования данного варианта предпринимательской сети являются:

- $\quad$ получение дополнительного эффекта от локальных процессов функционирования сетевых партнеров за счет снижения (или ликвидации) трансакционных издержек;

- получение дополнительного эффекта при выполнении объединенных (скооперированных) процессов ресурсного обеспечения сетевых партнеров;

- получение дополнительного эффекта при выполнении объединенных процессов по реализации продукции сетевых партнеров.

Для обеспечения этих условий необходимо: создание единых для всех сетевых партнеров закупочных и структур, занимающихся процессом реализации, которые обеспечивают централизованное выполнение транспортных, складских, информационно-рекламных операций.

Применительно к условиям строительного производства областью взаимодействия бизнес-единиц является обеспечение процесса возведения зданий и сооружений строительными материалами, а также сфера реализации строительной продукции. Данная сфера выживает те объекты, которые проектируются и сооружаются на основе инициативы участников инвестиционно-строительного рынка и реализуются в условиях свободных рыночных отношений. В специфических условиях современного рынка к ним относятся преимущественно объекты жилого назначения, обращающиеся на наиболее развитом рыночном сегменте.

Важно подчеркнуть, что сферу реализации строительной продукции следует рассматривать в расширенной трактовке, как сферу, в которой не только осуществляется собственно продажа продукции данного вида (например, элементы вводимых в эксплуатацию жилых зданий, квартиры, секции), но и обеспечивается выполнение функции продвижения продукции - стимулирования реализационных мероприятий, рекламирование строительной продукции и фирм-производителей, организация информационно-пропагандистских компаний на начальных этапах строительства или предшествующих ему.

Рассматриваемый вариант предпринимательской сети может с успехом использоваться представителями малого и среднего строительного бизнеса, ориентированных на производство отдельных видов работ.

Второй вариант предпринимательской сети соответствует производственной промежуточной кооперации. Одна организация изготавливает для другого либо отдельные элементы продукта, либо выполняет отдельные промежуточные технологические операции и работы, выпуская при этом свою специфическую продукцию.

Условиями эффективности данного варианта предпринимательской сети будут: 
- получение дополнительного эффекта локального функционирования сетевых партнеров от углубления их специализации;

- получение дополнительного эффекта от взаимодействия сетевых партнеров, обеспечивающая перераспределение и концентрацию однотипных работ на каждом из сетевых партнеров.

Между строительными организациями этот вид кооперации устанавливается в тех случаях, когда каждый из участников использует в собственном производственно-строительном цикле результаты деятельности других участников. В первую очередь, это касается производства специфических видов строительных работ, для осуществления которых используется материально-техническая база и трудовой потенциал партнеров.

Особенностью данной кооперации является взаимность отношений между партнерами.

Третий вариант конфигурации предпринимательской сети предусматривает поставки по кооперации конечной продукции отдельных организаций (Б 1 и Б3) которые используются как комплектующие в производственном процессе другого участника предпринимательской сети $\left(Б_{2}\right)$.

Условием эффективности данного варианта предпринимательской сети является:

- получение дополнительного эффекта сетевыми партнерами Б и Бз за счет устойчивой реализации части продукции;

- получение дополнительного эффекта сетевыми партнерами за счет устойчивого, на выгодных условиях снабжения комплектующими изделиями и за счет углубления своей специализации.

Для обеспечения этих условий необходимо организовать взаимодействие в рамках предпринимательской сети по выпуску, своевременной доставки на взаимовыгодных условиях изделий, комплектующих продукцию бизнес-единицы Б2.

Такая конфигурация предпринимательской сети характерна, например, для условий функционирования предприятий стройиндустрии. В процессе реализации строительных деталей и конструкций целесообразно налаживание партнерских отношений со строительно-монтажными организациями, которые позволяют предприятиям стройиндустрии:

- укрепить связи с конечными потребителями своей продукции (строительномонтажными организациями);

- использовать преимущества собственной специализации;

- решать стратегические задачи на основе заключения долгосрочных контрактов;

- повышать собственную рыночную устойчивость;

- снизить издержки на продвижение продукции и использовать элементы так называемого промышленного маркетинга, который регулирует рыночные взаимодействия между технологически связанными бизнес-субъектами.

Четвертый вариант предпринимательской сети соответствует специализации отдельных бизнес-единиц на выполнении определенных стадий производственного процесса. 
Он способствует: более глубокой специализации сетевых партнеров, а следовательно углублению разделения труда и повышению его производительности; сокращению производственного цикла изготовления продукции; повышению надежности поставок и снижению трансакционных издержек.

Для соблюдения условий эффективности надо обеспечить:

- рациональный уровень разделения и кооперации труда в сети;

- необходимую ритмичность производства;

- рациональные материальные потоки между сетевыми партнерами.

В строительстве этот вариант предпринимательской сети всегда связан с технологией строительного производства. Отдельные виды работ (в их технологической последовательности) осуществляется специализированными организациями строительного профиля участниками ПС. Такими участниками могут являться, в частности, организации, занимающиеся отдельными работами, например, установкой столярных изделий, кровельными работами, инженерным обеспечением возводимых зданий и сооружений.

Пятый вариант является смешанным, представляет комбинацию второго, третьего и четвертого вариантов.

Шестой вариант предпринимательской сети предусматривает кооперацию финансовых ресурсов $\left(\mathrm{K}^{\phi}\right)$ управленческих возможностей $\left(\mathrm{K}^{\mathrm{y}}\right)$; возможностей по разработке новой продукции $\left(K^{\mathrm{T}}\right)$. Он позволяет: повысить финансовую устойчивость сетевых партнеров; получить доступ к инвестициям; привлечь опытных специалистов - управленцев к обоснованию стратегически значимых решений как для сетевых партнеров, так для предпринимательской сети в целом.

В инвестиционно-строительном комплексе этот вариант получает широкое развитие. Во-первых, в качестве сетевых партнеров могут выступать инвесторы, заказчики, застройщики. Их коммуникативные взаимоотношения позволяют:

- укрепить рыночные позиции;

- обеспечить поиск дополнительных инвестиций, что особенно важно в условиях капитального производства, каковым является строительство;

- наладить прочные информационные контакты;

- приобрести дополнительные шансы для использования инструментов лоббирования со стороны органов регионального регулирования;

- расширить территориальные границы рыночной сферы;

- увеличить возможность получения крупных государственных заказов;

- использовать, по-существу, весь комплекс преимуществ, свойственных крупному бизнесу.

Во-вторых, как партнеры, могут функционировать строительные организации одного профиля. В этом случае их внутренние контакты позволят снизить уровень конкуренции, осуществлять единые управленческие решения в области управления рынком, а именно:

- координировать ценовые решения на любые виды строительной продукции (законченной строительством или представляющие собой элементы производственно-строительного цикла - строительные работы);

- осуществлять согласование базовых параметров качества строительной продукции; 
- использовать единые элементы коммерческой пропаганды;

- использовать современные средства рекламного воздействия (например, двухступенчатую рекламу, которая рассматривается международной практикой, как наиболее эффективный способ управления рынком) требующий высоких единовременных затрат.

В-третьих, в качестве партнеров в ПС могут войти организации инновационного профиля, в частности те из них, что осуществляют стратегию адаптации инновационных разработок к потребностям носителей спроса. В данном случае в качестве носителей спроса будут выступать строительные организации, испытывающие потребность в новых технологиях, способах использования строительных материалов и деталей, новых строительных машинах и механизмах, а также в инновационных способах организации и управления строительным производством. В качестве примера организации инновационного профиля, занимающейся "производством инноваций на заказ", можно привести опыт ООО "Центр ноу-хау", который обладает уникальной технологией формирования инновационных решений.

Сетевыми партнерами в данной предпринимательской сети могут быть венчурные организации, задачей которых является финансирование наукоемких инновационных разработок и использование различных мер поддержки инновационной деятельности. Строительный комплекс, как известно, относится к числу приоритетных объектов венчурного бизнеса.

Обобщив вышеизложенное правомерно утверждать, что каждая из предлагаемых шести моделей функционирования предпринимательских сетей может найти применение в деятельности инвестиционно-строительного комплекса. Структурное разнообразие этого комплекса является объективной основой для дифференциации моделей ПС. Эти обстоятельства свидетельствуют о необходимости предметного изучения принципов и методов управления предпринимательскими сетями.

Условием эффективного функционирования предпринимательской сети является превышение эффективности функционирования бизнес-единиц в качестве сетевых партнеров над их возможной эффективностью в условиях автономного функционирования. На основе анализа предпринимательских сетей сформированы следующие принципы их эффективности:

1. Принцип синергичности, который заключается в том, что эффективность функционирования бизнес-единиц в качестве сетевых партнеров должна превышать их эффективность при автономном функционировании.

2. Принцип сочетаемости общей эффективности предпринимательской сети с локальной эффективностью всех сетевых партнеров.

3. Принцип целевого соответствия (непротиворечивости) целей бизнесединиц, входящих в предпринимательскую сеть.

4. Принцип разнообразия эффектов предпринимательской сети учитывающих специфические интересы всех ее участников. 


\section{ГЛАВА 4 \\ ФОРМИРОВАНИЕ МЕХАНИЗМОВ ВЗАИМОДЕЙСТВИЯ СУБЪЕКТОВ ПРЕДПРИНИМАТЕЛЬСКОЙ СЕТИ В СТРОИТЕЛЬСТВЕ}

\section{1 Теоретические основы формирования сетевых объединений}

Формирование предпринимательских сетей связано с интегращионным поведением субъектов системы предпринимательства. Эти процессы базируются, прежде всего, на теоретическом осмыслении сущности предпринимательской деятельности и на изучении и понимании ее особенностей в меняющихся условиях внешней среды. Структура научно - методических работ, послуживших теоретической основой исследуемой проблемы, приводится в табл.4.1.

Таблица 4.1 - Структура теоретико-методологических основ формирования предпринимательских сетей

\begin{tabular}{|c|c|}
\hline Основные разделы теории & Авторы трудов \\
\hline $\begin{array}{l}\text { Формирование базовых понятий, вы- } \\
\text { явление экономической сущности пред- } \\
\text { принимательства на различных этапах его } \\
\text { развития и его поведение во внешней сре- } \\
\text { де. }\end{array}$ & $\begin{array}{l}\text { Р. Катильон, А. Смит, И. Тюнен, Т. Ман- } \\
\text { гольдт, Ф. Найт, М. Вебер, Й. Шумпетер, Дж. Б. } \\
\text { Кларк, Ж. Б. Сей и др. }\end{array}$ \\
\hline $\begin{array}{l}\text { Раскрытие закономерности и особен- } \\
\text { ности предпринимательства во второй по- } \\
\text { ловине XX века. }\end{array}$ & $\begin{array}{c}\text { Аккофф Р., Джордж Т.М., Дж. Кейнс, } \\
\text { М.Войнарец, Л. Мизес, Ф. Хайек, Ф. Котлер, И. } \\
\text { Кирцнер, Р. Хизрич, М. Питерс, Б. Карлоф и др. }\end{array}$ \\
\hline $\begin{array}{l}\text { Раскрытие особенности становления } \\
\text { предпринимательства в современной Рос- } \\
\text { сии. }\end{array}$ & $\begin{array}{l}\text { Асаул А.Н., Блинов Л., Бусыгин А.В., Каба- } \\
\text { ков В.С., Крупанин А.А., Казанцев А.К., Крутик } \\
\text { А.Б., Томилов В.В., Шатрова Е.В. }\end{array}$ \\
\hline $\begin{array}{l}\text { Анализ особенностей кооперации } \\
\text { производства и интеграции субъектов } \\
\text { предпринимательства в современных } \\
\text { условиях. }\end{array}$ & $\begin{array}{l}\text { Авдашева С.Б., Винслов Ю., Горбунов А.Р., } \\
\text { Долгопятова Т.Г., Майзель А.И., Пивоваров И.С. } \\
\text { и др. }\end{array}$ \\
\hline
\end{tabular}

Проблемам взаимодействия бизнес - субъектов, вертикальной и горизонтальной интеграции создания и развития в рыночной экономике посвящены работы: А.Н. Асаул, С.Б. Авдашевой, А.А. Горбунова, Т. Долгопятовой, Е.Г. Нестеренко, Д.А. Турчака, Л.С. Барютина и др., А.И.Майзеля, И.С. Пивоварова, Л.В. Ежкина и др.

С.А. Авдашева в книге "Хозяйственные связи в российской промышленности" исследует проблемы восстановления и формирования хозяйственных связей в российской экономике. Институционный вакуум, вызванный распадом командно - административной системы и переходом к рыночным методам хозяйствования, привел к формированию новой системы взаимоотношения бизнес-субъектов. 
Функционирующие в новых условиях бизнес-субъекты вынуждены активно взаимодействовать с поставщиками сырья и комплектующих изделий, пользователями своей продукции, сбытовыми подразделениями. Они широко используют вертикальные связи, позволяющие фирмам оказывать определенные влияния друг на друга.

Эти связи наиболее сильны на рынках с высокой концентрацией производства и в отраслях, где конкурентоспособность может быть достигнута только в результате масштабных инвестиций, типичным представителем которых является строительная отрасль.

Автор считает, что при выборе различных форм вертикальной интеграции должна учитываться неопределенность хозяйственных отношений, которая снижает эффективность гибридных форм интеграции и по сравнению с вертикальной интегрированной формой.

Тенденции развития бизнес-групп в России были проанализированы Т. Долгопятовой. Проведенный ею опрос убедительно доказал существенные потребности организаций в объединении своих усилий с целью взаимной поддержки и отстаивании общих интересов. Так около 70\% организаций (из числа опрошенных) находились в тесном интеграционном взаимодействии со своими партнерами, а 90\% производителей различных видов продукции хотели бы войти в отраслевое объединение, причем наиболее сильное.

Методологию формирования хозяйств и дочерних фирм анализирует А.P. Горбунов ${ }^{1}$. Основными предпосылками этого процесса он считает возможности эффективно налаживать кооперативные связи входящих в них организаций, проводить единую производственно-технологическую, инвестиционную, сбытовую политику. В качестве ведущей инвестиционной стратегии для взаимосвязанных производственно-хозяйственной деятельностью организаций рассматривается целенаправленное вложение средств в предприятия-изготовителей и предприятияпоставщиков сырья, деталей, комплектующих. По мнению автора, данная стратегия наиболее эффективно реализуется в рамках холдингового объединения, что позволяет контролировать инвестиционные процессы по всем элементам кооперационной цепочки. Кроме того, в рамках холдинга отношения между технологически взаимосвязанными организациями строятся на стабильной основе, т. к. холдинговая компания получает право участвовать в управлении предприятиями поставщиками. А.Р. Горбунов рассматривает возможность инвестирования взаимодействующих организаций на основе обмена пакетами их акций. В этом случае в управлении каждым из сотрудничающих организаций принимают участие представители партнеров, и появляется взаимная заинтересованность всех партнеров в успешном сотрудничестве, поскольку оно сроится на основе "разделение прибыли". Зарубежная практика показала эффективность этого метода инвестирования. Следует согласиться с мнением автора о целесообразности использования данного подхода в отечественном бизнесе.

1 Бухвальд Е., Виленский А. Российская модель взаимодействия малого и крупного предпринимательства // Вопросы экономики №12. 1999. 
А.Р. Горбунов считает целесообразным создание объединений на базе мелких и средних предприятий, которые могут входить поставщики сырья и компонентов, предприятия, изготовляющие комплектующие изделия и т. д. Автор считает, что даже небольшие предпринимательские звенья могут образовать гибкую сеть дочерних структур, обеспечивающих достижение разнообразных хозяйственных целей.

А.А. Турчак, Л.С. Барютин и др. в монографии "Интегрированные финансово - промышленные структуры" рассматривают проблемы создания и развития крупных интегрированных структур в России. Их появление базируется на акционировании, приватизации, слиянии, разделении, присоединении. Все эти действия связаны с новым подходом к кооперации и разделению труда, с разрушением старых производственных связей с формированием новых моделей взаимодействия и взаимосвязи различных субъектов рыночной экономики. Авторы рассматривают преимущественно хозяйственные объединения, полностью интегрирующие деятельность отдельных бизнес - субъектов, т.е. превращающие их в единый, укрупненный субъект хозяйствования. В работе так же раскрываются особенности функционирования хозяйственных объединений, в которых отдельные организации не теряют полностью свою самостоятельность (тресты, синдикаты, холдинги и т. д.)

Особый интерес представляют предложения авторов по формированию стратегических альянсов, которые могут оформляться в форме безвозмездного договора о научно - техническом сотрудничестве либо протокола о намерениях. К сожалению, методическая проработка данной формы интеграции в работе отсутствует.

Авторы считают, что необходима целевая комплексная государственная программа структурной перестройки промышленности и селективного предоставления финансовых средств и других преференций, что в определенной степени противоречит принципам рыночной экономики. Прежде всего, рыночные механизмы и стимулы должны способствовать интеграционным процессам в народном хозяйстве. По мнению А.И. Майзеля и И.С. Пивоварова длительное и глубокое взаимодействие бизнес - субъектов наиболее эффективно в рамках холдинга, что позволяет разрабатывать общую оптимальную стратегию, решать инвестиционные проблемы и снижать управленческие риски. Вхождение бизнес-субъекта в группу (холдинг) должно увеличивать его потенциал. У него появляется возможность привлечения ресурсов других участников и снижения общей потребности в инвестициях благодаря углублению кооперации участников группы. В тоже время отрицательной стороной вхождения бизнес - субъекта в объединение является определенное ограничение его свободы и соответствующее снижение гибкости. Путь создания холдинга сверху агрессивен, он подразумевает скупку акций компании и стремление к их поглощению. Более цивилизованным путем является создание холдинга "снизу" на основе объединения юридически независимых компаний с учреждением холдинг - центра. Участники данного объединения вносят в качестве учредительного вклада любые активы: деньги, ценные бумаги, здания, оборудование, интеллектуальную собственность и т. д. Такая форма объединения наиболее предпочтительна для равновесомых предприятий, заинтересованных в 
сохранении самостоятельности и определенной независимости и в тоже время желающих установить длительное и эффективное взаимодействие с другими бизнес - субъектами.

А.И. Майзелем и И.С. Пивоваровым довольно глубоко проанализированы проблемы создания и развития холдинга, в то же время другие виды предпринимательских групповых структур авторы практически не рассматривали, что в определенной степени противоречит названию работы.

В работе "Корпоративный бизнес" Е.В. Ленский, анализируя межфирменную интеграцию, выделяет ее жесткие и мягкие формы: "жесткие" - трест, концерн (холдинг); "мягкие" - ассоциации, консорциумы, стратегические альянсы. Мягкие формы позволяют вести совместную работу при сохранении юридической и хозяйственной самостоятельности. В их рамках возникает возможность использования преимущества мощной корпоративной структуры при сохранении хозяйственной, национальной, юридической обособленности членов. В то же время следует помнить, что границы между различными формами межфирменной интеграции достаточно расплывчаты и зачастую разными специалистами трактуются по-разному.

Ряд ученых считает, что малый бизнес должен преимущественно развиваться с опорой на крупный. Так О.В. Чечетина в статье "Перспективы развития предпринимательских сетей в России считает, что малый бизнес в производственной сфере целесообразно развивать, что малые фирмы либо стремятся занять ниши рынка, невыгодные для внедрения труда крупных компаний, либо финансируются ими, ведя инновационные разработки, рискованные для корпорации. Это позволяет ему преодолевать свои ресурсные проблемы.

В статье "Корпоратизация и реструктуризация как две стороны реформирования предприятия" ${ }^{1}$ авторы Одинцов М.В. и Ежкин Л.В. рассматривают в качестве одного из вариантов реформирования бизнес-структур их вхождение в объединения, консорциумы без создания юридического лица. При этом каждая организация самостоятельно осуществляет свою производственно - хозяйственную деятельность, но координирует ее со своими партнерами. Они раскрывают место и значение корпоратизации в процессе структурной перестройки предпринимательского объекта. Авторы утверждают, что в современных условиях функционирования экономики, российскому менталитету наиболее близка корпоративная форма существования и развития бизнеса.

Рассмотрение научно - методических основ предпринимательства позволило сформулировать базовые определения и принципы формирования и функционирования предпринимательских сетей:

- потребность в реализации принципа заинтересованности всех участников предпринимательских сетей;

- рассмотрение интеграционной деятельности предприятия как новаторской, как создание новых комбинаций факторов производства;

${ }^{1}$ Предпринимательство: итоги, проблемы, перспективы // Под ред. А.И. Муравьева. -СПб.: СПбГУЭФ, 1997. 
- потребности в нового рода координации средств производства, выходящие за рамки одного предпринимательского субъекта;

- рассмотрение возможностей интегрированного поведения в предпринимательской сети по передаче части функций от собственника менеджерам профессионалам;

- использование вхождения в предпринимательскую сеть для более эффективного регулирования взаимоотношений с внешней средой;

- использование возможностей предпринимательской сети для разделения труда, специализации, кооперации, как производственного процесса, так и управленческих процессов, происходящих в субъектах предпринимательской деятельности.

Анализ научно- методических основ предпринимательства показал:

1. Основой предпринимательства как автономного, так и интегрированного является хозяйственная инициатива, творческая, ответственная предпринимательская структура, выдвигающая и реализующая инновационные предложения.

2. Предпринимательская деятельность осуществляется в определенной внешней среде, в определенных природных и социально - экономических условиях, в определенных рамках, задаваемых общественным мнением и органами государственного управления. Они, эти условия, рамки могут быть благоприятными для формирования предпринимательских сетей.

3. Развитие теоретико-методологической базы предпринимательства ведется, прежде всего, по пути осмысления роли и возможностей предпринимательской деятельности в новых условиях, в видоизмененной рыночной конъюнктуре. Она нуждается в разработке научно-методических рекомендаций, обеспечивающих нахождение лучших решений по развитию и функционированию системы предпринимательства (и в частности предпринимательских сетей) в настоящий период и на перспективу.

4. В экономических исследованиях пока отсутствует завершенное комплексное научное обоснование проблемы формирования оптимальных предпринимательских сетей, которые в максимальной степени соответствовали бы целям и задачам их участников, состоянию и возможностям внешней среды.

\section{2 Особенности создания и развития предпринимательских сетей в стро- ительстве}

Основными чертами строительства как специфической отрасли материального производства, как известно являются:

техническая и организационная сложность сооружаемых объектов;

длительность строительного цикла;

сложность производственного процесса;

разнородность видов работ и технологических процессов строительного производства; 
необходимость масштабного инвестиционного обеспечения, что обуславливает необходимость системного рассмотрения капитального строительства в составе единого инвестиционно-строительного комплекса.

Капитальное строительство - это сложный многофакторный процесс, требующий взаимодействия множества организаций и значительных трудовых затрат, ресурсов, финансов в течение длительного времени.

В инвестиционно-строительном комплексе функционирует ряд субъектов (бизнес-субъектов инвестиционно-строительного комплекса), основные из которых представлены на рис.4.1.

Перед участниками инвестиционно-строительного рынка ставятся задачи обеспечения эффективного совместного функционирования, взаимосвязи с предприятиями стройиндустрии, подрядными организациями, задействованными в реализации - технологической цепочки. Бизнес-субъекты различны по характеру деятельности, потребности в инвестициях и ресурсном обеспечении продолжительности плановых периодов и производственным процессам.

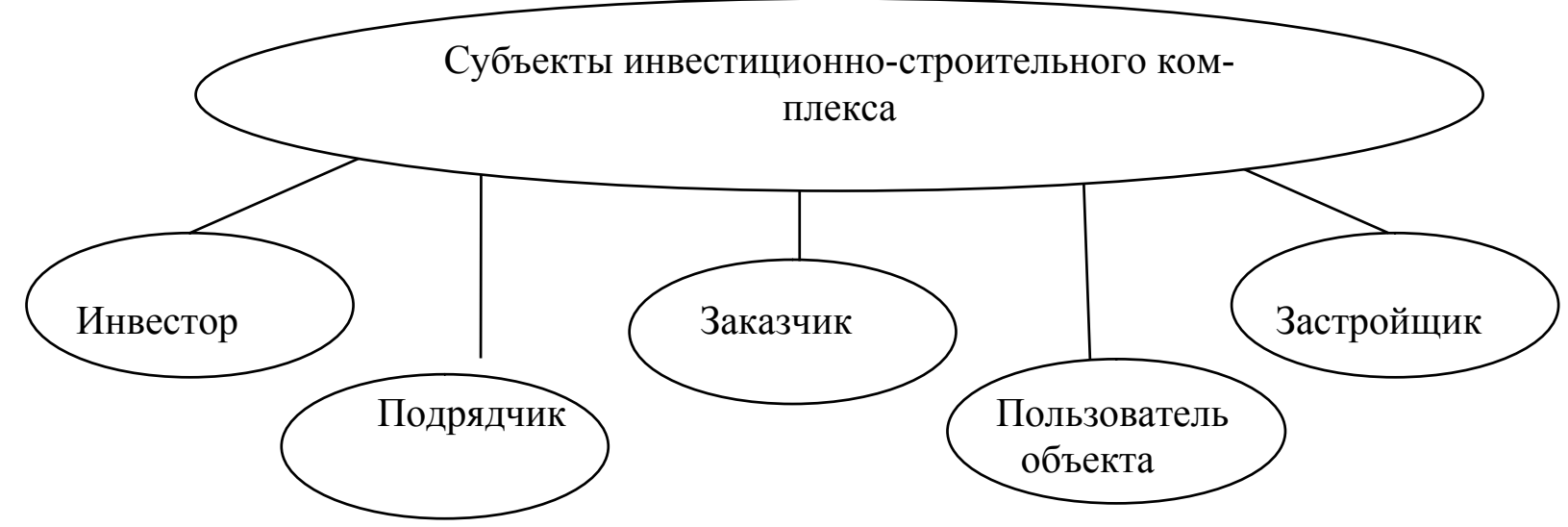

Рис.5.1. Субъекты инвестиционной деятельности в строительстве

Гармонизация целей и задач предприятий, являющихся участниками единой технологической сети является очень сложной и многовариантной задачей. Наиболее целесообразны два подхода к ее решению:

- создание диверсификационных строительных компаний;

- создание предпринимательских сетей.

Стратегия диверсификационной строительной компании включает такие мероприятия, как:

- создание и управление хозяйственным портфелем структурных подразделений корпорации (приобретение компаний, укрепление существующих деловых позиций, прекращение деятельности, не соответствующей управленческим планам);

- достижение синергизма среди родственных структурных подразделений и превращение его в конкурентное преимущество;

- установление инвестиционных приоритетов и направление корпоративных ресурсов в наиболее привлекательные сферы деятельности; 
- разработку мер, направленных на усиление конкурентоспособности и сохранение конкурентных преимуществ;

- формирование механизма реагирования на внешние изменения;

- объединение стратегических действий основных функциональных подразделений;

- усилия по решению специфических вопросов и проблем компании.

Необходимо отметить, что в российском строительном бизнесе наблюдаются разные варианты интеграционного роста. Интеграционный рост может осуществляться в следующих формах.

Горизонтальная интеграция с другими бизнес-субъектами аналогичного профиля и получение дополнительных преимуществ за счет сокращения конкуренции.

Диверсификация в рамках вертикальной интеграции:

a) регрессивная интеграция: покупка или постановка под жесткий контроль предприятий-поставщиков строительных материалов и подрядчиков;

б) прогрессивная интеграция: приобретение или постановка под жесткий контроль риелторских и рекламных компаний, формирование собственной системы реализации построенного жилья.

Базовой мотивацией в деятельности строительной организации являются возможности ее выживаемости в условиях противостояния факторов микросреды (формирующейся в пределах организационной структуры строительной организации), адаптации к воздействию макросреды и наращивания потенциала конкурентного преимущества за счет более эффективного управления внутренними факторами. Мотивация к "выживанию" следует в современной теории мотиваций рассматривается как более действенный мотив, нежели другие мотивы в деятельности организации (обеспечение прибыльности, экономического роста, дальнейшего развития, достижение определенной рыночной доли, другие мотивы). На основе этой мотивации формируется стратегия ограниченного роста.

Несвоевременность или невозможность получения заказов для строительной организации определяется воздействием факторов как внешней, так и внутренней среды (качеством стратегического управления, эффективностью производства, качеством и эффективностью применяемых ресурсов (условиями их комбинирования), преимуществом в конкурентоспособности организации, ее продукции и, в конечном итоге, преимуществом в конкурентоспособности социальноэкономического развития организации. Ограничения в получении заказов, как и несвоевременные обязательные платежи и невыполнение денежных обязательств, означают, по-сути, окончание экономического жизненного цикла даже для прибыльной организации. Вполне очевидно, что цели выживания в критических ситуациях имеют явное преимущество для организации в соотношении с другими целями, ставящимися в рамках предпринимательской деятельности.

В свою очередь, достижение цели выживания является предпосылкой для достижения других целей и задач предприятия. С позиций исследуемой проблемы увеличения конкурентоспособности строительной организации за счет ее включения в ПС правомерной представляется ранжировка целевой политики организации: 
- получение заказов и загрузка производственно-строительной базы;

- наращивание конкурентного потенциала в обеспечении производственной и финансовой устойчивости в стремлении обеспечить конкурентное преимущество максимально продолжительный период времени;

- повышение социально-экономического развития организации с учетом наращивания конкурентного преимущества в использовании человеческого потенциала, снижения риска утраты заказов и темпов социально-экономического развития, получения приемлемой прибыли, достаточной для обеспечения конкурентного преимущества и развития организации в максимально продолжительный период времени.

В зависимости от условий, создаваемых внутренней и внешней средой бизнес-субъектов инвестиционно-строительного комплекса имеют разную структуру, разный набор входящих в их организацию. При этом их стратегия развития представляет собой набор модифицированных стратегий, разных для каждого конкретного элемента этого комплекса (строительно-монтажных организаций, предприятий стройиндустрии, организаций, выполняющих отдельные виды строительных работ).

Стратегия роста может планироваться для инвестиционно-строительных компаний в целом, если они имеют очевидные конкурентные преимущества или если прогнозируется значительный рост рынка.

Стратегия сокращения предполагает установление целей на уровне более низком, чем достигнутый в прошлом, а также ликвидацию либо продажу компании или ее отдельного подразделения. Обычно к стратегии сокращения прибегают тогда, когда показатели деятельности приобретают устойчивую тенденцию к ухудшению и никакие меры не изменяют этой тенденции. Однако эту стратегию, особенно в отношении отдельных производств, следует рассматривать как нормальную корпоративную сделку, осуществляемую, когда стоимость продажи структурного подразделения превышает приведенную стоимость ожидаемых от него денежных потоков. В настоящее время многие строительные компании ставят вопрос об эффективности поддержки некоторых дочерних предприятий, в частности, по производству строительных материалов, поскольку конкуренция на этом рынке постоянно растет, что приводит к снижению цен. В этих условиях невыгодно иметь собственную компанию, которая из-за ограниченных объемов производства не в состоянии обеспечить аналогичный уровень себестоимости.

Таким образом, окончательная стратегия инвестиционно-строительной компании представляет собой комбинацию, сочетание рассмотренных альтернатив ограниченного роста, роста и сокращения для каждой из ее структурных единиц.

Общий план управления любой многопрофильной компанией обычно включает в себя ориентацию на стратегию быстрого роста большинства наиболее перспективных предприятий, обеспечение нормального функционирования основных сфер деятельности, проведение мероприятий по поддержанию и восстановлению деловой активности на низкоприбыльных, но перспективных направлениях, отказ от непривлекательных или не соответствующих долгосрочным планам корпорации сфер бизнеса.

Возможные изменения стратеги (стратегия ограничения роста, стратегия со- 
кращения и т.д.) можно рассматривать как своевременную реакцию на изменяющиеся внешние условия. Эти изменения наиболее безболезненно могут реализовываться в рамках предпринимательской сети, а не в жестком централизованном холдинге. Среди факторов внешней среды, оказывающих наиболее заметное воздействие на строительную отрасль следует отметить:

1. Общие экономические:

Финансовая политика национальных банков по привлечению капитала в производство и строительство:

- уровень развития инвестиционно-строительной деятельности;

- направление инвестиций в основной капитал;

- значимость строительного комплекса (доля валовой добавленной стоимости строительства в общем объеме ВВП);

- уровень бюджетного инвестирования.

Соотношение промышленного и гражданского строительства.

Параметры использования природно-сырьевых ресурсов:

- уровень запасов природно-сырьевых ресурсов, используемых в строительстве.

Уровень качества использования природно-сырьевых ресурсов (экспортноимпортное соотношение ресурсов и уровень их вторичной переработки, для используемых в строительстве).

Воздействие кризиса неплатежей на устойчивость строительных организаций:

- недофинансирование федеральных и региональных инвестиционных программ;

- просроченная задолженность заказчиков строительным организациям.

2. Экономико-правовые:

Правовая среда (стабильность гражданского и коммерческого законодательства). Гарантия надежности инвестиций иностранных государств-партнеров по бизнесу.

Таможенная политика.

Лицензионная политика.

Налоговая политика (изменение налоговых ставок, налоговых льгот).

Кредитно-денежная политика (изменение учетной ставки ЦБ, валютного курса рубля, либерализация бюджетных ассигнований).

Регулирование несостоятельности (банкротства) организаций.

Амортизационная политика.

Экономико-правовое стимулирование привлечения инвестиций в жилищное строительство (развитие ипотеки, государственные гарантии по вкладам и сбережениям населения).

Государственная стратегия по охране окружающей среды и обеспечению устойчивого развития.

3. Социально-демографические: Структура потребительской среды (инвесторы, заказчики, потребители):

- по уровню маркетинговых переменных (доходы, возрастная структура и др.);

- по изменению стиля жизни, вкусов и предпочтений и др.; 
- по изменению структуры рынка и рабочей силы;

- по отношению к стоимости и качеству жилья;

- по уровню платежеспособного спроса.

4. Рыночная: Величина спроса, стабильность спроса, эластичность спроса.

Требования заказчиков к цене, качеству, срокам строительства.

Разнообразие (сегментация) заказчиков (потребителей).

Экономический потенциал заказчиков (потребителей) по платежеспособности.

Конъюнктура рынков трудовых ресурсов.

Конъюнктура рынков финансовых ресурсов.

Конъюнктура рынков средств производства.

Принципы сегментирования рынка.

Анализ (мониторинг) параметров внутренней и внешней среды позволяет обосновывать управленческие решения по выбору стратегии развития строительных организаций.

Стремление предприятий снизить риски приводят к конгломератным объединениям. Такие решения не всегда оправданы, так как затрудняют управление объединением, включающим структурные подразделения разной целевой направленности. Экономическая целесообразность такого рода объединений не всегда реализуема. Ряд авторов считают, что наиболее эффективным путем развития строительной компании является вертикально-интегрированный холдинг ${ }^{1}$. Так, стратегия вертикальной диверсификации может включать:

- регрессивную интеграцию (положение производителей сырья и оборудования);

- диверсификацию путем создания дочерних предприятий (по производству оборудования, выделение производственных отделов, по техническому обслуживанию построенных объектов и т.д.);

- создание дочерних предприятий в сфере торговли недвижимостью, в сфере рекламы;

- подразделения для централизованного планирования, контроля и управления финансами.

На наш взгляд такой вертикально-интегрированный холдинг с централизованным управлением тоже имеет право на существование и как показывает практика они успешно развиваются, например холдинговая группа "Ленстройреконструкция" (ЛСР) целенаправленно инвестирует средства в приобретение новых предприятий, производящих основные строительные материалы и модернизацию существующих.

С приобретением ряда организаций по добыче и поставке морского песка ЛСР стала монополистом с объемом выпуска 3 млн. м ${ }^{3}$ в год с последующим доведением его до 5 млн. Покупка 90\% пакета акций крупного производителя бетона ЗСК №19 позволили группе занять 35\% рынка товарного бетона. В группу ЛСР входят и другие производители строительных материалов, такие как завод по производству кирпича "НПО Керамика".

${ }^{1}$ Интегрированные финансово-управленческие структуры. Под ред. А.А. Турчака. -СПб.: Изд-во Наука, 1996. 
В 2002 г. в составе ЛСР появился Гатчинский домостроительный комбинат крупнейшая в регионе домостроительная компания. Инвестиционная программа холдинга группы ЛСР рассчитана до 2005 г. и предполагает вложения в размере около 70 млн. долл.

В 2002 г. холдинг "Ленстройматериалы", ранее специализировавшийся на добыче нерудных материалов и производстве строительных материалов широкого ассортимента (щебень, кирпич, песок), приобрел крупнейший в регионе Гатчинский сельский строительный комбинат и инвестировал в производство около 1,5 млн. долл. Это позволит улучшить качество панелей и увеличить мощность комбината.

Интеграция холдингов "Ленстройматериалы" и "Ленстройреконструкция" произошла в последующие переделы ("вперед") с целью увеличения добавленной стоимости, т.е. получения большей прибыли. Есть и другие примеры. Так, ЛенСпецСМУ и "Строительная компания №1 - ЛЭК" приобрели ряд заводов строительных материалов, чтобы защитить себя от монополии поставщиков, совершив интеграцию в первые переделы ("назад").

Укрупнение строительного рынка в регионе приведет к концентрации строительства массового жилья в нескольких крупных компаниях и снижению его себестоимости. Тенденция диверсификации производственной деятельности получает в регионе широкое развитие. При этом компании используют разные стратегии: от расширения своей деятельности за пределы региона ("Строймонтаж", ЛЭК, "Ленстройреконструкция" в Москву) или государства (ЛенСпецСМУ в Югославию) до продажи контрольного пакета акций зарубежным холдингам ("Петербургстрой" - холдингу "Skanska") ${ }^{1}$.

Основная часть функционального аппарата в отечественных строительных компаниях сосредоточена в высших уровнях управления. Это вызвано объективными причинами: масштабностью материальных потоков и т.д. В то же время это подавляет инициативу среднего управленческого звена и мешает своевременному и качественному решению оперативных вопросов.

Можно предположить, что такая жесткая, иерархическая организационная структура управления строительными компаниями эффективна только в определенных случаях, в условиях реализации крупного сложного проекта, реализуемого в жесткие сроки и т.д.

Необходимо учитывать, что в стране наряду с крупными строительными объектами (сосредоточение в основном в Москве, Санкт-Петербурге и нескольких других городах) имеется огромный спрос на строительные работы среднего объема.

Кроме этого, создание гигантских строительных компаний (монополистов городского, регионального и т.д.) выхолаживает конкуренцию и решение о выделение заказов зачастую решается чисто бюрократически.

Bсе это еще раз показывает необходимость и целесообразность использова-

${ }^{1}$ Подробнее см. : Развитие регионального инвестиционно-строительного комплекса на основе самоорганизации // Современное экономическое и социальное развитие: проблемы и перспективы. - Ученые и специалисты Санкт-Петербурга и Ленинградской области Петербургскому экономическому форуму 2003. СПб., 2003. 
ния сетевого предпринимательства в строительстве.

В крупном строительном бизнесе работают компании, холдинги, которые по сути дела являются едиными в той или иной мере централизованными организациями (они были рассмотрены выше в главе I). Они могут самостоятельно выполнять основные (а иногда и все) виды строительных работ.

В области среднего и малого бизнеса чаще всего используется традиционный хозяйственный способ (своими силами) и подрядный, с привлечением сторонних организаций.

Хозяйственный способ имеет преимущество в том, что нет необходимости в привлечении и согласовании различных исполнителей. Недостаток в том, что привлекаемые строительно-монтажные участки, как правило невысокого технического уровня.

Подрядный способ строительства осуществляется рядом строительномонтажных организаций, обладающих достаточно мощным потенциалом. На основе договора-подряда могут выполняться следующие виды работ:

- строительство, ввод в действие производственных мощностей;

- производство отдельных видов и комплексов строительно-монтажных услуг;

- пуско-наладочные работы;

- проектно-изыскательские работы;

- научно-исследовательские;

- опытно-конструкторские.

При этом может заключаться и единый договор на проектирование, строительство и ввод в эксплуатацию производственных мощностей и объектов.

Основная задача - это оптимальный подбор участников, позволяющих наилучшим образом использовать их потенциал. Основным документом, обеспечивающим правовое регулирование их взаимоотношений, является договор подряда между ними.

Практически формируется предпринимательская сеть. Очевидно уровень отношений ее участников может в отдельных случаях доходить до стратегического альянса, предусматривающего налаживание длительных производственных связей с возможной, в определенных направлениях, интеграцией и кооперацией.

Конкретизируя элементы потенциала бизнес-единицы применительно к строительству можно дать следующую характеристику:

Товар, работа (услуга), характеризуется $\left(\Pi_{\mathrm{T}}\right)$ : научно-техническим уровнем продукции, качеством выполнения работы, ее соответствием лучшим зарубежным образцам, архитектурным решениям и т.д.;

Производственный параметр (П П характеризует:

- уровень технологии производства конкурентоспособной строительной продукции;

- длительность производственного процесса;

- уровень технологии, обеспечивающей высокий уровень технической и экологической безопасности производственного процесса и продукции;

- уровень прогрессивности средств и методов производства строительной продукции (работ, услуг);

- уровень загрузки производственных мощностей; 
- уровень использования и наращивания мощностей за счет интенсивных и экстенсивных факторов;

- возможности прироста мощностей за счет собственных источников средств.

Ресурсная обеспеченность $\left(\Pi_{\mathrm{p}}\right)$ характеризует:

- уровень соответствия лучшим зарубежным аналогам;

- уровень соответствия лучшим отечественным аналогам;

- уровень соответствия аналогам главного конкурента;

- удельный вес применяемых новых видов сырья, строительных материалов, изделий, конструкций;

- соответствие применяемых строительных материалов требованиям участия и выигрыша подрядных торгов;

- соответствие применяемых строительных материалов экологической безопасности продукции;

- эффективность использования материально-сырьевых ресурсов;

- соответствие запасов материалов, изделий рациональной их величине;

- зависимость организации от использования импортных строительных материалов;

- эффективность использования оборотных средств (оборачиваемость, фондоотдача и др.).

Финансовая составляющая производственного потенциала включает $\left(\Pi_{\phi}\right)$ :

- структура имущества;

- структура баланса;

- уровень дивидендов.;

- уровень прибыли и рентабельности;

- соотношение собственных и заемных средств, основных и оборотных средств;

- уровень финансовой устойчивости;

- показатели ликвидности;

- показатели финансового состояния;

- показатели оборачиваемости;

- показатели рентабельности;

- уровень просроченной задолженности по уплате обязательных платежей;

- уровень просроченной задолженности по уплате денежных обязательств;

- уровень чистой прибыли, оставляемой в распоряжении организации;

- уровень целевого накопления и использования амортизации;

- уровень рентабельности продукции;

- уровень авансовых платежей заказчиков;

- уровень просроченности задолженности со стороны заказчиков;

Управленческую составляющую элементов потенциала $\left(\Pi_{y}\right)$ характеризует:

- минимальное число уровней иерархии управления;

- соответствие норме управляемости;

- соответствие организационной структуры размерам организации;

- эффективность применяемых форм, методов и способов реорганизации управленческой структуры;

- уровень квалификации персонала относительно организаций региона (отрас- 
ли), главного конкурента.

Диагностика потенциала стратегической организации может повлиять на выбор одного из следующих решений по дальнейшему существованию бизнесединицы: продажа, слияние, техническое переоснащение, вхождение в предпринимательскую сеть.

При формировании предпринимательской сети в строительстве необходимо в первую очередь обосновать ее следующие параметры:

- сочетаемость производственно-технологических характеристик сетевых партнеров (по качеству, производительности и т.д.);

- сочетаемость производственных мощностей строительных организаций, специализирующихся на выполнении отдельных работ (услуг);

- сочетаемость организационных культур;

- надежность, исполнительность, умение взаимодействовать;

- ценовую политику и ее приемлемость для всех участников сети.

Укрупненный алгоритм формирования управленческих решений по формированию предпринимательской сети в строительстве представлен на рис.4.2.

Формирование предпринимательских сетей в строительстве должно базироваться на следующих принципах:

1. Обеспечения реализации возможностей по концентрации, кооперации и специализации отдельных строительных организаций, которые становятся сетевыми партнерами.

2. Сочетаемости и единой направленности целей и задач участников предпринимательской сети.

3. Оптимальной скоординированности их действий в пространстве времени.

4. Взаимной выгодности взаимодействия всех участников сети.

В рамках предпринимательской сети представителями малого строительного бизнеса можно обеспечить эффект концентрации производства и специализации на основе кооперирования специализированных организаций, обеспечивающих выполнение отдельных работ в составе производственно-строительного цикла. При этом их кооперационное взаимодействие должно и может осуществляться не на принципах подчинения, а на договорных началах, базирующихся на взаимовыгодных экономических связях.

5. Оптимальной скоординированности их действий в пространстве времени.

6. Взаимной выгодности взаимодействия всех участников сети.

В рамках предпринимательской сети представителями малого строительного бизнеса можно обеспечить эффект концентрации производства и специализации на основе кооперирования специализированных организаций, обеспечивающих выполнение отдельных работ в составе производственно-строительного цикла. При этом их кооперационное взаимодействие должно и может осуществляться не на принципах подчинения, а на договорных началах, базирующихся на взаимовыгодных экономических связях. 


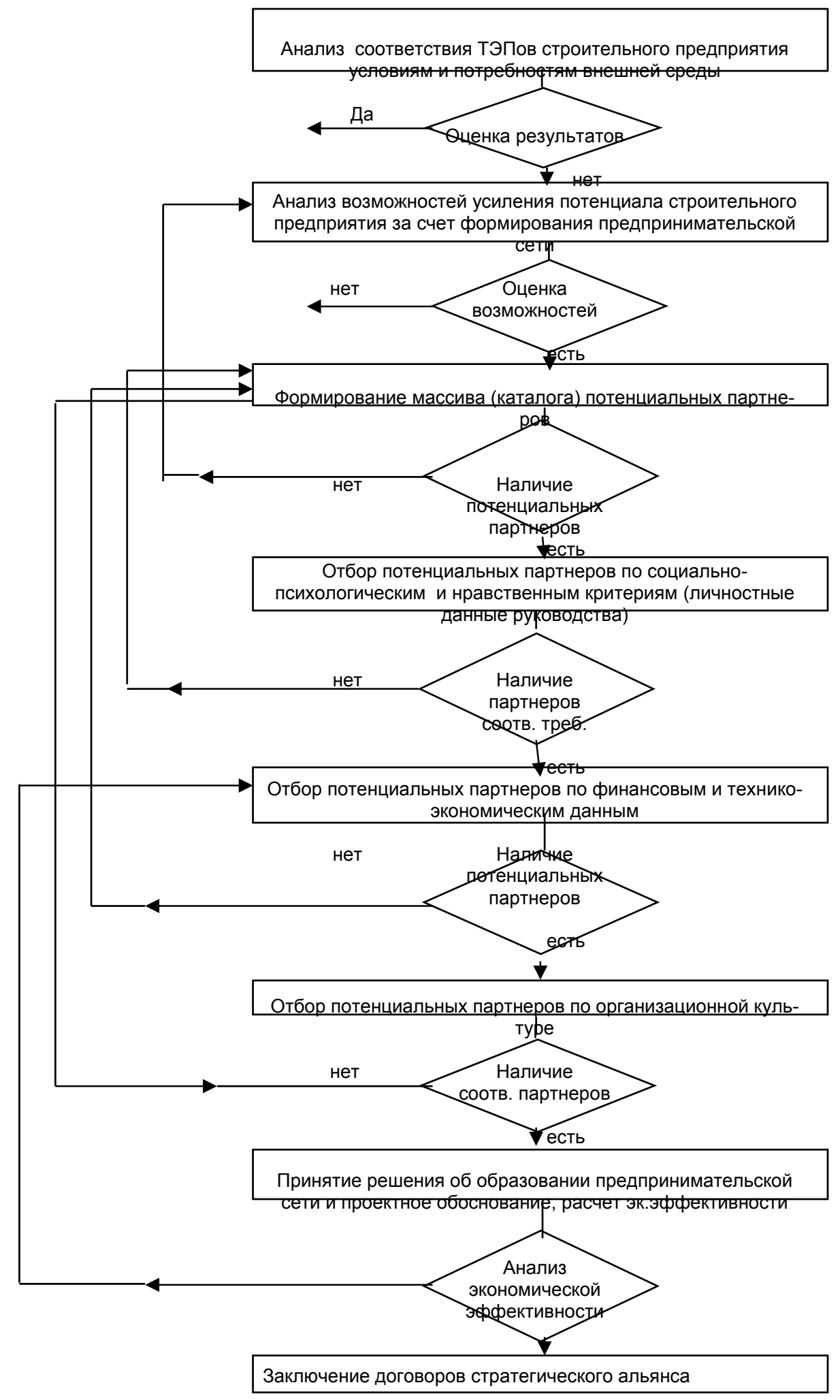

Рисунок 4.2 - Укрупненный алгоритм формирования управленческого решения по формированию предпринимательской сети в строительстве

В Северо-Западном регионе при непосредственном участии автора диссертационного исследования была сформирована производственно-сетевая организа- 
ция ОАО "Проектно-строительное объединение "Леноблагрострой".

На начало 2003 г. в производственную сетевую организацию ОАО "ПСО "Леноблагрострой" входило 12 малых предприятий (из которых шесть - областных): ООО "ПСО "Леноблагрострой-Кировск", ЗАО "Агросервис", ООО "Возрождение" (г. Кировск), ООО "Гатчина-Агрострой", ООО "Домостроительная инвестиционная компания", производственный кооператив "Курск" (г. Всеволожск), ЗАО "Лесстрой", ООО "Агрострой" (г. Лодейное поле), ООО "Лира", ЗАО "Трис", АООТ "Лугаагрострой", ООО "Базальт-Строй".

Следует отметить, что предпринимательская деятельность вышеназванных организаций осуществляется самостоятельно на основе собственных балансов основных фондов и средств, а отношения с "ПСО "Леноблагрострой" носят договорной характер.

Производственная сеть формируется на основе принципа диверсификации, что позволяет в рамках деятельности сети осуществлять разноплановые направления строительной деятельности силами, входящих в сеть малых предприятий.

Так, например, ООО "Гатчина-Агрострой" имеет производственноскладскую базу в г. Гатчине и обеспечено необходимым набором строительной техники, технологического автотранспорта и средств малой механизации. Работы ведутся преимущественно в г. Гатчине и Гатчинском районе.

ЗАО "Лесстрой" является генеральным подрядчиком по строительству жилых и производственных зданий, выполняет весь комплекс работ со сдачей объектов под ключ и осуществляет внедрение новых строительных технологий. Работы ведутся в г. Санкт-Петербурге и Ленинградской области, преимущественно в Северо-Западном направлении.

Основными видами деятельности ООО "Возрождение" являются: агропромышленное строительство; монтаж металлоконструкций, технологического оборудования, сантехнических систем, систем вентиляции и аспирации; электромонтажные работы, ремонт животноводческих ферм, техническое обслуживание доильного оборудования, монтаж АДМ-8, введение новшеств по монтажу и восстановлению старых доек и их технологических схем.

АООТ "Лугаагрострой" занимается реконструкцией, строительством и капитальным ремонтом жилых домов, объектов соцкультбыта на территории Лужского района, Ленинградской и Новгородской областей.

Объединение перечисленных малых предприятий в веть "ПСО "Леноблагрострой" способствовало повышению конкурентного статуса, как головной организации, так и предприятий, входящих в сеть, увеличению объемов производства и появлению ряда преимуществ в области маркетинговой политики.

Так, например, объединение в сеть позволило принимать участие в торгах на осуществление различных проектов и выигрывать их в равной конкурентной борьбе. В частности, в результате выигранных торгов было введено 6 тыс.кв.м жилья в г. Санкт-Петербурге. Кроме того, за последнее время одним из наиболее успешных строительных проектов, выигранных на тендерных торгах "ПСО "Леноблагрострой", является проект реставрации "Домик в Коломне" (бывший дом купца С.И.Рыбкина, построенный в XVIII в. и являющийся памятником архитектуры) в исторической части г. Санкт-Петербурга, работы по которому ведутся, 
входящими в сеть малыми предприятиями.

В качестве объектов нового строительства, осуществленного малыми предприятиями, входящими в производственную сеть "ПСО "Леноблагрострой", следует отметить Гатчинские горэлектросети, индивидуальное жилищное строительство во Всеволожском районе Ленинградской области, прокладку дорог с асфальтовым покрытием в пос. Ленинское Ленинградской области, благоустройство жилых микрорайонов Выборгского района г. Санкт-Петербурга.

Из общественно значимых реконструированных объектов следует выделить: управление образованием МО "Гатчинский район", Санкт-Петербургский Государственный университет, детский сад №1 г. Санкт-Петербурга, школу №608 г. Санкт-Петербурга, спортивную школу в г. Санкт-Петербурге, Государственный Русский музей, Мариинский театр, здание Госконсерватории, театр им. А.С.Пушкина, Государственный аграрный университет.

Таким образом, шаги структурной перестройки "ПСО "Леноблагрострой"в производственную сеть поступательно планируются и реализуются при осуществлении активной политики привлечения организаций инвестиционностроительного комплекса Петербургского региона. Развитие аналогичных направлений деятельности, по нашему представлению, приведет к созданию и широкому распространению таких корпоративных структур как производственная сеть, что будет соответствовать государственной политике в сфере малого предпринимательства.

Основные принципы объединения:

1. Формирование единого информационного пространства через взаимодействие головной предпринимательской структуры с участниками производственной сетевой организации (генерация и обмен новой информацией; единство финансового, технологического и правового пространства).

В целях дальнейшего развития системы информационного обеспечения субъектов малого предпринимательства на основе действия индустриальных сетей необходимо обеспечить доступность информации по малому бизнесу для органов управления, предпринимательских структур, зарубежных и международных организаций; создать сети информационно-аналитических центров в регионах на базе производственных сетевых организаций.

Центры на основе единых критериев интегрируют и производят информационные ресурсы. Перечень информационных услуг может уточняться в процессе организации информационно-аналитических центров на основе анализа потребностей конкретных пользователей. При этом сеть информационно-аналитических центров формируется по региональному и отраслевому принципам и базируется на имеющемся в настоящее время опыте работы в области информационных услуг.

Реализация мер должна опираться на систематизированные статические, аналитические данные о развитии малого предпринимательства в России, о зарубежной практике, тенденциях и перспективах российского малого предпринимательства с учетом хода экономических реформ.

2. Совершенствование процессов производства продукции, выполнения работ, оказания услуг (внедрение эффективных технологий, новых предпринима- 
тельских решений и т.д.).

3. Формирование общей коммерческой политики и политики внешнеэкономической деятельности (с участием в предпринимательских проектах, приобретение необходимых ресурсов).

4. Повышение профессионального уровня персонала; стимулирование труда и социальная защита.

Как показала практика, несмотря на хозяйственную независимость предпринимательских структур, объединенных в производственную сеть, между ними существуют сильные этические, организационные, финансовые, деловые и иные связи, делающие эти субъекты предпринимательства устойчивыми и надежными партнерами.

\section{3 Проблемы развития предпринимательских сетей в строительстве}

Строительство представляет особую отрасль народного хозяйства, формируемую определенной группой специфических хозяйственных единиц ${ }^{1}$. Для нее характерны:

- особые условия производства в системе общественного разделения труда;

- специфическая продукция;

- специфические технологии и техническая база;

- специфический кадровый состав;

- специфические условия работы.

Очевидно, что рассмотренные в предыдущем разделе общие принципы и методы предпринимательской деятельности относятся и к строительной отрасли народного хозяйства. В то же время, указанные выше отраслевые особенности требуют их учета при решении ряда вопросов развития предпринимательства в строительном комплексе ${ }^{2}$.

Государственный комитет Российской Федерации по статистике ежеквартально проводит выборочные обследования деловой активности строительных организаций в 79 регионах Российской Федерации. Обследование дает оценку взглядов их руководителей на текущую конъюнктуру в сфере строительного бизнеса и перспектив его развития.

Такое обследование проводилось, в частности, во II квартале 2002 г. В нем приняли участие 5,4 тыс. строительных организаций.

Результаты обследования строительных организаций, проведенного во II квартале 2002 г., свидетельствуют о наметившихся тенденциях улучшения экономиче-

${ }^{1}$ О создании финансово-промышленных групп в Российской Федерации: Указ Президента РФ от 5 декабря 1993г. №2096 // Экономика и жизнь № 51, 1993.

${ }^{2}$ Клепач А., Кузнеиов П., Крючкова П. Корпоративное управление в России в 1995-1996 // Вопросы экономики №12,1996. Развитие корпоративных форм хозяйствования в России / По материалам конференции, проведенной Международной академией корпоративного управления // Российский экономический журнал №2,3, 1998. Социально-экономическое положение России. - Государственный комитет Российской Федерации по статистике №12, 2000. 
ской ситуации в строительном секторе: увеличилось число заключенных договоров, наблюдается тенденция к росту объема работ, выполненных по договорам строительного подряда. Это во многом связано с сезонным характером работ.

Руководители 78\% строительных организаций во II квартале 2002 г. оценили экономическую ситуацию в отрасли как "благоприятную" и "удовлетворительную".

Более трех четвертей (77\%) руководителей строительных организаций не ожидают изменений экономической ситуации в отрасли. Руководители 16\% строительных организаций считают, что экономическая ситуация в строительстве улучшится, 7\% респондентов ожидают ее ухудшения.

Показательные данные, характеризующие деловую активность российских строительных организаций в 2001 г., представленные в журнале "Инвестиционный рынок", №2, за 2002 г.

Итоги обследования деловой активности строительных организаций свидетельствуют о дальнейшем развитии позитивных тенденций в строительной отрасли в 2001 г.:

- повысился спрос на услуги подрядных организаций;

- величилась средняя загрузка производственных мощностей;

- продолжился рост доли предприятий, на которых отмечено увеличение численности занятых;

- смягчилась ситуация с обеспеченностью строительного сектора собственными финансовыми ресурсами;

- в IV квартале впервые за истекший год доля строительных организаций, руководители которых отмечают рост прибыли, превысила долю тех, кто сообщает о ее снижении.

Как следствие позитивных изменений основных показателей отрасли наблюдалось улучшение оценок предпринимателями экономической ситуации в данном секторе экономики, а значение индекса "предпринимательской уверенности" 1 , характеризующего предпринимательский климат в строительстве, возросло с (-23)\% в I квартале до (-18)\% в IV квартале 2001 г.

Вместе с тем, развитие строительного сектора продолжают сдерживать финансовые проблемы: высокий уровень налогов, неплатежеспособность заказчиков, а также высокая стоимость материалов, конструкций и изделий.

В течение всего 2001 г. в строительном секторе сохранялась относительно благополучная ситуация с заказами на выполнение подрядных работ. Данное обстоятельство позволяет говорить о формировании достаточно стабильного спроса на услуги подрядных организаций, что обусловило реальное повышение деловой активности в этом секторе экономики.

Доля строительных организаций, портфель заказов которых соответствовал "нормальному" уровню, возросла с 49\% в I квартале до 60\% в IV квартале 2001 г.

Еще более заметны позитивные изменения портфеля заказов строительных ор-

1 Этот индекс рассчитывается как среднее арифметическое "балансов" оценок уровня производственной программы и ожидаемых изменений численности занятых (влияние сезонного фактора исключено), в процентах. 
ганизаций в конце 2001 г. относительно соответствующего периода предыдущего года.

Рост спроса способствовал увеличению доли строительных организаций, у которых зафиксировано расширение физического объема работ и числа заключенных договоров. В IV квартале доля предприятий, на которых отмечен рост физического объема работ, выполняемых по договором строительного подряда, превысило долю тех, у которых зафиксировано его снижение (об этом свидетельствуют как фактические данные, так и данные без учета влияния сезонного фактора).

Баланс ${ }^{1}$ оценок изменения показателя (без учета влияния сезонного фактора) в IV квартале 2001 г. составил (+8)\% против (-6)\% в III квартале 2001 г. и (+8)\% в IV квартале 2000 г.

Улучшение спроса на услуги строительных организаций обусловило постоянный рост в течение 2001 г. загрузки производственных мощностей. B IV квартале 2001 г. средний уровень загрузки мощностей в строительном секторе составил $61 \%$.

Самый высокий уровень использования производственных мощностей отмечен в организациях с численностью персонала свыше 200 человек. На протяжении 2001 г. показатель изменялся в интервале 65-69\%. Низкий уровень загрузки производственных мощностей сохранялся в течение года на предприятиях с численностью занятых менее 50 человек - соответственно 46-49\%.

Средняя обеспеченность финансированием заключенных договоров в течение 2001 г. составляла 4 месяца. По сравнению с прошлым годом она увеличилась на 1 месяц, что свидетельствует о некотором улучшении финансовой ситуации в строительном секторе. В группировке по численности занятых хуже обеспечены финансированием подрядные организации с численностью занятых до 50 человек - в среднем 2 месяца. Самая высокая обеспеченность финансированием отмечена на крупных предприятиях с численностью занятых свыше 200 человек - 5 месяцев. В значительной мере это обусловлено характером самих заказов. Крупные строительные фирмы выполняют более масштабные заказы, имеющие достаточно продолжительные сроки выполнения и финансирования.

Расширение портфеля заказов строительных организаций и улучшение динамики физического объема работ, выполненных по договорам строительного подряда, привели к существенному улучшению в 2001 г. оценок изменения численности занятых в строительстве. Впервые за все время наблюдений в III квартале 2001 г. фактические оценки зафиксировали превышение доли предприятий, на которых отмечен рост занятости, по сравнению с долей предприятий, сокращающих персонал. В значительной степени это было определено влиянием сезонного фактора, однако тенденция к стабилизации положения с занятостью прослеживается и при устранении сезонной волны. Так, по данным с элиминированной сезонностью, доля строительных организаций, у которых численность занятых снижается, пока преобладает над долей тех, у которых зафиксирован ее рост. Вместе с тем, темпы сокращения численности занятых в 2001 г. заметно снизились по

${ }^{1}$ Баланс - разность долей респондентов, отметивших увеличение и уменьшение показателя по сравнению с предыдущим кварталом, в процентах. 
сравнению с 2000 г.

Следует отметить, что тенденция роста числа занятых проявилась в основном в крупном строительном бизнесе. Так, баланс изменения показателя в крупных строительных фирмах с численностью работников свыше 200 человек повысился с $(-8) \%$ в 1 квартале 2001 г. до (-1)\% в конце года, при этом во II и III кварталах, являющихся наиболее активными для строителей, баланс изменения численности имел положительные значения (соответственно $(+7) \%$ и $(+15) \%)$.

Сохраняющийся невысокий спрос на услуги малого строительного бизнеса и, соответственно, нестабильная динамика физического объема работ предопределили негативные оценки состояния занятости в малых строительных организациях. Наиболее сложное положение сохраняется в группе предприятий с численностью работников не более 50 человек. Однако следует иметь в виду, что и в этой группе предприятий интенсивность сокращения численности занятых замедлилась - c (-31\%) в I квартале 2001 г. до (-13\%) в IV квартале 2001 г.

Повышению деловой активности в отрасли в 2001 г. способствовали позитивные изменения в финансовом положении организаций строительного комплекса.

Оценки предпринимателями финансовой ситуации строительных организаций формировались в условиях улучшения положения с обеспеченностью собственными финансовыми средствами, сокращения просроченной задолженности заказчиков по оплате выполненных работ и роста доли прибыльных предприятий.

Об улучшении обеспеченности подрядных организаций собственными финансовыми ресурсами в 2001 г. свидетельствуют как фактические данные, так и данные без учета влияния сезонного фактора. Так, баланс оценок изменения показателя увеличился с (-13)\% в I квартале до (-7)\% в IV квартале 2001 г. Несмотря на то что оценка обеспеченности собственными финансовыми ресурсами, как и ранее, остается отрицательной, это лучшее значение показателя за весь период наблюдения.

Благоприятная ситуация со спросом и связанное с этим расширение объемов строительного производства в 2001 г. способствовали улучшению положения с прибылью у предприятии строительного комплекса (об этом свидетельствуют и фактические данные, и данные без учета влияния сезонного фактора).

В 2001 г. получило более широкое распространение использование строительными фирмами банковских кредитов. Пока трудно оценить, является ли это признаком возросшей привлекательности строительной отрасли для банковского сектора, но в 2001 г. воспользовались кредитами банков в среднем 35\% подрядных организаций, тогда как в течение четырех предыдущих лет $75 \%$ строительных фирм не могли себе этого позволить.

Как следствие укрепления финансового положения строительных организаций в 2001 г. отмечена некоторая активизация их инвестиционной деятельности, что связано, в первую очередь, с ослаблением дефицита собственных финансовых ресурсов, за счет которых преимущественно осуществляются инвестиции. Так, в 2001 г., по оценкам предпринимателей, капитальные вложения осуществляли $30 \%$ строительных организаций против $25 \%$ в 2000 г., рост инвестиций отмечен у $4 \%$ строительных организаций против 2-3\% в предыдущем году. 
Лучшими финансовыми возможностями для технологического перевооружения своих предприятий обладают крупные строительные фирмы. В частности, среди строительных компаний с численностью занятых свыше 200 человек доля организаций, осуществляющих инвестиции, возросла с $33 \%$ в I квартале до 42\% в IV квартале 2001 г. По-прежнему невысока инвестиционная активность малых строительных организаций. Для малой строительной индустрии сложнее сконцентрировать средства для внедрения новой техники, технологии производства, новых материалов и конструкций.

В 2001 г. сохранялось опережение роста цен на строительные материалы и конструкции по сравнению с ростом цен на строительно-монтажные работы. Так, баланс оценок изменения цен на строительные материалы в IV квартале 2001 г. составил $(+82) \%$, а на строительно-монтажные работы - $(+69) \%$ (в I квартале 2001 г. соответственно $(+86) \%$ и $(+72) \%)$. Вместе с тем, по оценкам предпринимателей, в 2001 г. по сравнению с 2000 г. темпы роста цен на строительные материалы, конструкции и изделия несколько замедлились.

Ситуация с ценами в строительном секторе, по оценкам предпринимателей, в ближайшей перспективе не претерпит существенных изменений. Сохранится дальнейший рост цен как но строительные материалы, так и на строительномонтажные работы, при этом темпы роста цен на строительные материалы попрежнему будут опережать темпы роста цен на строительно-монтажные работы. Эту тенденцию можно интерпретировать как фактор, сдерживающий развитие предпринимательской активности строительного сектора.

В течение года отмечено некоторое снижение доли "теневых оборотов" в объемах строительно-монтажных работ. Если в I квартале не проходили официального оформления в среднем до 9\% выполненных контрактов, то в конце года документально не оформили 7\% выполненных строительно-монтажных работ.

Пока еще рано говорить о стремлении строительных фирм "выйти из тени", но цифры свидетельствуют о позитивных изменениях в этом направлении. 


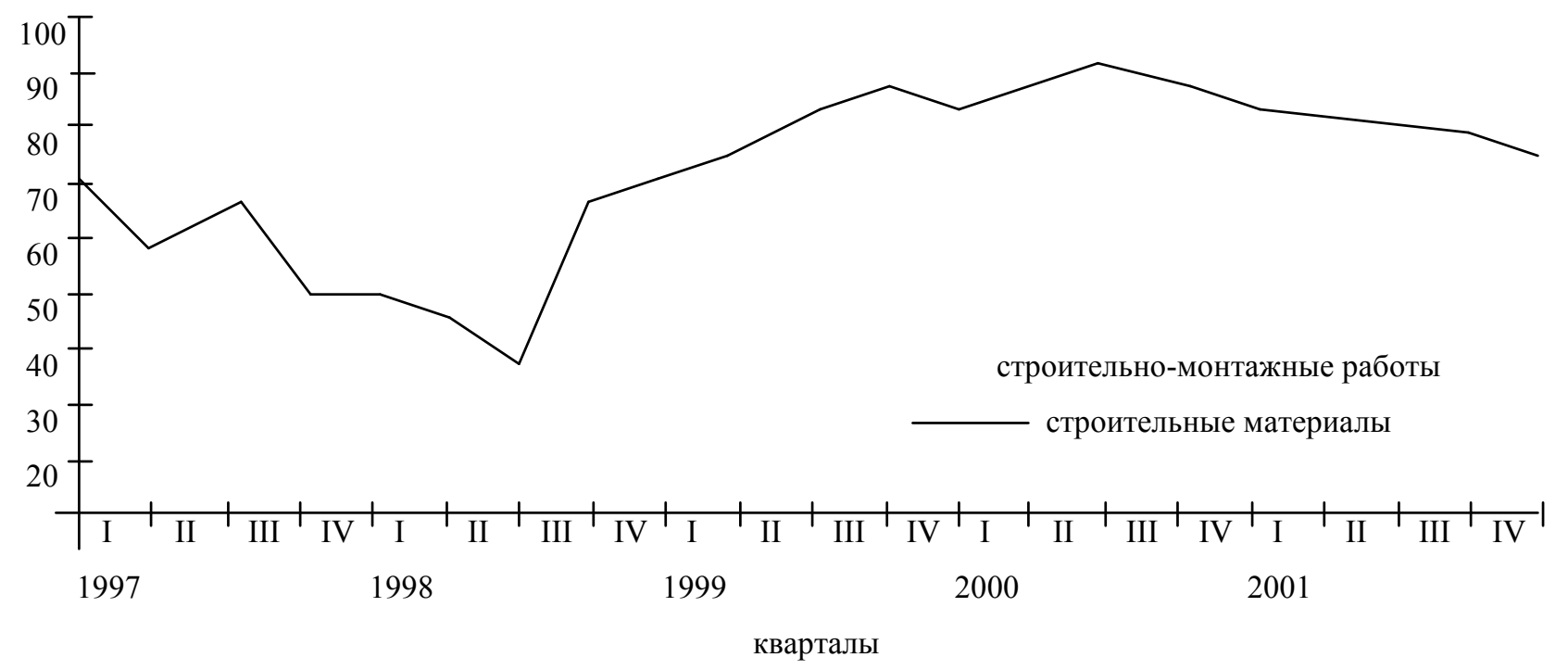

\section{Рисунок 4.3 - Динамика оценок изменения цен на строительно-монтажные работы и строительные материалы}

Анализ современных проблем функционирования строительного комплекса России дан в работах: А.Н.Асаула ${ }^{1}$, А.А.Горбунова ${ }^{2}$, В.Г.Кулибанова ${ }^{3}$, Ю.Н.Казанского ${ }^{4}$, В.А.Заренкова ${ }^{5}$, Е.А.Толмачева, Н.В.Чепаченко ${ }^{6}$, Л.Т.Чистова ${ }^{7}$ и др.

${ }^{1}$ Асаул А. Н. Предпринимательская деятельность в строительном комплексе. -

СПб.: Экономические науки, 1996. Асаул A. Н. Феномен строительного комплекса в современных экономических условиях / Экономика Украины №3, 2003. Асаул A. Н. Развитие новых региональных производственных систем на основе самоорганизации / Нов1 виробнич1 системи і развиток економши Украши (матер1али економ!чного самм1ту) м. Луцьк, 2003. Асаул A. $H .$, Денисова И. В. Интеграция строительных фирм в форме сетевых индустриальных организаций Регион: политика, экономика, социология», №1, СПб., 2001. Асаул А. Н., Батрак А. В. Корпоративные структуры в региональном инвестиционно-строительном комплексе. - СПб.: Издво АСВ, СПбГАСУ, 2001. Асаул А. Н. Формирование системы управления строительным комплексом в современных условиях / Регионы и отрасли проблемы инвестиционной политики // Материалы международной конференции МАИЭС Владимир Суздаль, 19-22.02.2002г. Изд-во Владимирского государственного университета, 2002. - С. 328-339. Асаул А. Н., Иванов С. Н. Актуальность создания и эффективное управление корпоративными строительными структурами петербургского региона / Международная академия менеджмента. Научн. тр. Вып. IV. M., 2003.

${ }^{2}$ Горбунов А. А., Иванов С. Н. и др. Формирование региональных строительных комплексов в транзитивной в транзитивной экономике.

${ }^{3}$ Горбунов А. А., Кулибанов В. С, Кротов В. Ю. Прогнозирование и регулирование инвестиционно-строительной деятельности в регионе. - СПб.: Изд-во «Банк Петровский» АОЗТ «ПФ», 1995.

${ }^{4}$ Казанцев А. К., Крупанин А. А. Менеджмент в предпринимательстве: Учеб. Пособие. М.: ИНФРА-М, 2002.

5 Интегрированные финансово-управленческие структуры. Под ред. А. А. Турчака. СПб.: Изд-во Наука, 1996.

${ }^{6}$ Чепаченко Н.B., Мамакова T. A. Совершенствование механизма управления процессом обеспечения конкурентных преимуществ строительных организаций с учетом реализации функций маркетинга и контроллинга // Экономические проблемы повышения эффективности инвестиционной деятельности в современных условиях. - СПб.: СПбГИЭУ, 2001. Чистов Л. $M$. Оптимизация управления социально-экономическими системами. В 2-х ч. - СПб.: СпбГУ, 1999.

7 Чечеткина О. В. Перспективы развития предпринимательских связей в России / Вестник московского университета. Сер.6. Экономика, 1, 2000. 
А.Н.Асаул в монографии "Предпринимательская деятельность в строительном комплексе" проанализировал изменения строительного комплекса при его вхождении в рыночную экономику. Формирование региональных строительных комплексов исследовалось в работе А.А.Горбунова и др....Также рассматривались особенности транзитивной экономики в отношении строительной отрасли. Авторы отличают, что "... все строительные организации и предприятия строительных материалов и конструкции выступают как простая совокупность производителей, объединяемых соответствующими товарными рынками, на которых строительство выступает в качестве покупателя продукции промышленности строительных материалов и конструкции, и, одновременно, продавца построенных объектов инвесторами".

В работе указывается на целесообразность организационного объединения всех участников технологической цепочки, участвующих в производстве конечного продукта (готового к продаже здания или сооружения).

А.А.Горбунов считает, что демонтаж системы централизованного планирования, разукрупнение и приватизация строительных объединений образовали на среднем уровне управления строительной отраслью глубокий вакуум. По мнению автора, в условиях переходной экономики России организация процессов регулирования и развития инвестиционной деятельности должна решаться на уровне регионов с учетом их особенностей, потребностей и интересов государства ${ }^{1}$.

В рамках регионального строительного комплекса различные строительные фирмы и предприятия стройиндустрии объединяются совместным участием в создании конечной продукции, реализации инвестиционного проекта. Очевидно, что характер взаимоотношения между отдельными участниками инвестиционностроительного комплекса, стабильность и жесткость связей между ними, методы корректировки их деятельности и организационно-правовые формы их интеграции могут быть различными, а выбор наилучших в конкретных условиях является теоретически и практически сложной задачей.

Проведенный Н.В. Чепаченко ${ }^{2}$ сравнительный анализ трансформации базовых принципов управления деятельностью организации позволил выявить важный фактор, снижающий эффективность строительных организаций. Это, по мнению авторов, низкая социальная ответственность менеджмента пред своим персоналом и обществом. Автор считает, что необходимы новые подходы к управлению строительными организациями, необходимы разработка этого обеспечения их конкурентоспособности. Уровень качества социально-экономического развития организаций позволяет, по мнению автора, давать оценку ее конкурентоспособности и определять пути ее появления. Базовыми инструментами эффективного управления разных строительных организаций должен быть системный подход.

${ }^{1}$ Горбунов А. А., Иванов С. Н. и др. Формирование региональных строительных комплексов в транзитивной экономике. Горбунов А. А., Кулибанов В. С, Кротов В. Ю. Прогнозирование и регулирование инвестиционно-строительной деятельности в регионе. - СПб.: Изд-во «Банк Петровский» АОЗТ «ПФ», 1995.

2 Чепаченко Н. В., Машакова Т. А. Совершенствование механизма управления процессом обеспечения конкурентных преимуществ строительных организаций с учетом реализации функций маркетинга и контроллинга // Экономические проблемы повышения эффективности инвестиционной деятельности в современных условиях. - СПб.: СПбГИЭУ, 2001. 
Стратегические альтернативы развития строительных организаций были проанализированы в монографии В.А. Заренкова. Он исследовал возможности и результаты конгломератных слияний компании и пришел к выводу, что они позволяют снизить "отраслевой" риск, но не позволяют существенно повысить качество управления. Автор считает, что наиболее перспективной стратегией роста строительной компании является формирование вертикально-интегрированного холдинга. Вертикальная интеграция позволяет компании чувствовать себя уверенной на рынке, осуществлять сквозные планирования для всех участников интеграции, на всех стадиях производственного цикла' ${ }^{1}$

При проектировании структур управления важно отойти от представления структуры как устоявшегося набора элементов, соответствующих каждой специализированной функции управления. Она должна иметь возможность самореформироваться при изменении факторов внешней среды, усложнении объектов строительства, изменении требований заказчиков и др. Это достигается эффективностью информационных и коммуникационных взаимосвязей между элементами организационных структур управления.

По мнению автора, эффективное управление интегрированной строительной организацией должно предусматривать сочетания жестких иерархических структур в сфере стратегического планирования и управления финансовыми потоками и адаптивных структур, легко перестраиваемых для реализации конкретных задач.

Анализируя структуру управления российских компаний, В.А.Заренков приходит к выводу, что вопросы формирования управленческой структуры компании, централизации и децентрализации управленческих решений еще недостаточно изучены. А именно - штабная и линейно функциональные структуры, наиболее распространенные в управленческой практике далеко не всегда подходят для строительных кампаний, чья деятельность характеризуется: высоким уровнем диверсификации значительными масштабами производства, территориальной разобщенностью дочерних структур, высокой изменчивостью внешней среды. При формировании управленческой структуры не всегда учитывается тот факт, что, чем выше степень изменчивости окружающей среды, тем большей гибкостью должна обладать структура.

Рост строительных компаний, увеличение одновременно реализуемых проектов почти всегда сопровождаются сохранением уровня централизации в принятии оперативных управленческих решений. В то же время существует часто практика неоправданного вмешательства менеджеров высшего уровня в решение оперативных вопросов.

Свойственное строительной отрасли четкое технологическое разграничение различных этапов и видов строительных работ создает предпосылки для децентрализованного управления, специализации производственных подразделений и их выделения в имеющие определенную самостоятельность предприятия. Такой подход увеличивает жесткость компании и позволяет лучше использовать потенциал ее подразделения.

Строительство, как особую отрасль материального производства формирует

\footnotetext{
${ }^{1}$ Интегрированные финансово-управленческие структуры. Под ред. А. А. Тур-чака. СПб.: Изд-во Наука, 1996.
} 
определенная группа хозяйственных единиц эффективность их действия определяется принятой комбинацией факторов производства.

Особенности строительного процесса обусловлены участием большого количества предпринимательских субъектов:

инвестор, физическое или юридическое лицо, осуществляющее финансирование строительства;

заказчик, физическое или юридическое лицо, уполномоченное реализовать инвестиционный проект и управляющего по строительству объекта;

застройщик, обладающий правами на земельный участок;

подрядчик - строительная фирма, осуществляющая по договору подряда или контракта строительство объекта;

пользователь, физическое или юридическое лицо для которого создается объект;

проектировщик - организация, осуществляющая по контракту с заказчиком (застройщиком) разработку проекта.

Участники строительного процесса могут совмещать функции нескольких субъектов: инвестор может выступать в роли заказчика, кредитора, выполнять функции застройщика и т.д.

Каждый из субъектов строительного процесса может иметь разные целевые установки на различных стадиях строительства:

инвестор, заказчик (застройщик) заинтересованы в минимизации капитальных вложений и в сокращении сроков строительства;

подрядчик, заинтересован в максимизации прибыли не только за счет сокращения производственных затрат, но и за удорожания строительства, что противоречит интересам инвестора, заказчика.

Основным правовым документом, регулирующим взаимоотношения между ними, является договор подряда. Могут заключаться генеральные, прямые и субподрядные договора. Генеральный договор заключается заказчиком с подрядчиком строительно-монтажной организацией на все время строительных работ. В свою очередь, генеральный подрядчик по согласованию с заказчиками может привлекать для выполнения отдельных видов работ организации - субподрядчиков (на основании субподрядных договоров). Для субподрядчика заказчиком является генподрядчик, который принимает на себя всю ответственность за результаты выполнения работ предусмотренным договором.

Основными исправлением повышения эффективности строительного производства, по аналогии с другими отраслями производственного комплекса, являются: концентрация, специализация, кооперирование и комбинирование.

Концентрация производства в строительстве идет преимущественно экстенсивным путем, за счет увеличения количественного увеличения производственных ресурсов (строительных машин, оборудования, работников). Экономический эффект концентрации достигается за счет увеличения масштабов производства и снижения удельных расходов. Этот эффект обусловлен влиянием укрупнения единичных мощностей, возможностью снижения издержек и т.д. Эффект масштаба несет ограниченный характер: снижается производственная гибкость, усложняется управление, растет опасность монополизации. 
Концентрация строительного производства может происходить на основе специализации и кооперации. При этом увеличивается количество производимых строительных работ при сокращении их номенклатуры.

Специализация в строительстве проявляется в создании специализированных организаций, выполняющих различные строительные работы или ориентированные на строительство объектов определенного функционального назначения.

Развитие специализированного производства требует налаживания четких и эффективных связей между предприятиями, задействованных в различных стадиях строительного производства и выполняющих конкретные виды работ.

Кооперирование в строительстве в условиях рыночной экономики основывается как взаимодействие обладающих хозяйственной самостоятельностью организаций строительного профиля, принимающих участие в реализации инвестиционных проектов.

Наличие множества субъектов строительной отрасли, часть из которой имеют различные экономические интересы обуславливает сложность выбора деловых партнеров и регулирование их взаимоотношений. Преодолевая эту сложность формируются группы субъектов строительной отрасли, которые устойчиво взаимодействуют друг с другом в строительном процессе и образуют предпринимательскую сеть'.

Большинство строительных компаний стремятся диверсифицировать свою деятельность. Осуществление стратегии диверсификации сопровождается появлением инвестиционно-строительных холдингов и ряда дочерних организаций. Дочерние организации холдинга, представляющие собой звенья единой технологической цели, значительно различаются по виду и характеру своей деятельности. Это сужает возможности для их совместного управления ${ }^{2}$. Обеспечение эффективного совместного функционирования разнопрофильных организаций, занятых в строительстве, реконструкции и технической эксплуатации зданий и сооружений является усложненной многофакторной задачей.

Анализ теории и практики интеграционных процессов, наблюдаемых в инвестиционно-строительном комплексе позволил выявить ряд проблем на пути создания эффективных производственно-строительных сетей. Основными из них в контексте исследуемой тематики являются:

1. Отсутствие согласованности в деятельности отдельных строительных организаций, занятых в строительном процессе, интегрированном по-сути, а также предприятий, выпускающих строительные материалы, детали, конструкции, которые выступают не как партнеры, а как субъекты рынка, реализующие собственные интересы и не использующие преимущества сетевого взаимодействия.

2. Несогласованность многих управленческих решений, принимаемых на среднем (региональном) уровне управления инвестиционно-строительным ком-

${ }^{1}$ Смит A. Исследования о природе и причинах богатства народов. - М.: Экономика, 1962. Чистов Л. М. Оптимизация управления социально-экономическими системами. В 2-х ч. - СПб.: СПбГУ, 1999.

${ }^{2}$ Семенов $C$, Кооперация производства - фактор устойчивости. Российский экономический журнал №12, 1998. 
плексом, что не способствует эффективному взаимодействию бизнес-субъектов строительного рынка.

3. Широкое применение конгломератного слияния компаний, не позволяет существенно повысить качество управления объединением и входящими в него организациями.

4. Наличие структур управления различного рода объединений, малоадаптивных к изменениям факторов внешней среды (усложнению объектов строительства, динамики потребительских предпочтений, появлению новых материалов конструкций, строительных технологий, разнообразных архитектурнопланировочных решений и т.п.).

5. Недостаточно полное использование преимуществ предпринимательской сети для обеспечения эффективной кооперации строительных организаций.

6. Фрагментарность изучения научно-методических аспектов формирования эффективных предпринимательских сетей в строительстве.

Решение указанных проблем, по мнению автора, может быть найдено на основе всестороннего изучения методологии формирования предпринимательских сетей, ее адаптации к условиям и перспективам развития инвестиционностроительного комплекса (во всем многообразии его составляющих), а также совершенствовании методического инструментария, предлагаемого к использованию в практике экономических обоснований по вопросам обеспечения оптимального функционирования ПС в строительстве.

\section{4. Принципы и методы регулирования процессов создания и развития предпринимательских сетей}

Целями создания предпринимательской сети является: решение проблем, стоящих перед входящими в нее бизнес - единицами, на основе их надежного устойчивого взаимодействия; повышение их эффективности; получение синергетического эффекта ${ }^{1}$.

Бизнес - единица, входящая в предпринимательскую сеть, выбирает стратегию интегрированного развития и функционирования, иманентно присущую сетевому подходу. Обоснование данной стратегии является функцией стратегического менеджмента.

Бизнес - единицы, входящие в предпринимательскую сеть, приобретают статус сетевых партнеров и объединяют свои цели на взаимовыгодной основе.

Процесс создания предпринимательской сети - это процесс реформирования предприятия с целью повышения его эффективности.

При разработке стратегии интегрированного развития бизнес - единицы затрагиваются интересы их партнеров, и возникает необходимость анализа их воз-

${ }^{1}$ Асаул А. Н., Батрак А. В. Корпоративные структуры в региональном инвестиционностроительном комплексе. - СПб.: Изд-во АСВ, СПбГАСУ, 2001. Багиев Г. Л., Асаул А. Н. Организация предпринимательской деятельности. СПб.: СПбГУЭФ, 2001. 
можностей и проблем. Поэтому ПС целесообразно рассматривать как единый, самостоятельный объект управления, имеющий свою цель, свои ресурсы и свои пути достижения поставленной цели (см. раздел 2.1). Рассматривая в качестве основных параметров предпринимательской сети - наличие и степень гибкости, обуславливающей возможной их адаптации к рыночной конъюнктуре важно подчеркнуть, что недостаток гибкости в координации взаимодействия приводит к снижению возможности своевременного реагирования на возникновении отрицательных рисков, а также на появление дополнительных стимулирующих факторов.

Чрезмерная гибкость может привести к нерациональному использованию имеющихся у партнеров ресурсов.

Взаимодействие партнеров по бизнесу в сети осуществляется с учетом следующих принципов, базирующихся на положениях теории рыночных коммуникаций: партнерство (учет взаимных интересов); многогранность; долгосрочная ориентация; утилитарность (целевая направленность на извлечение полезности во взаимодействии); уникальность; зависимость от других связей партнеров; адаптивность; изменчивость отдельных параметров при сохранении общей стабильности; учет всех видов логистических потоков, сопровождающих бизнес - коммуникации.

Регулирование предпринимательских сетей включает в себя обоснование и реализацию комплексов управленческих решений по:

- формированию предпринимательской сети;

- обеспечению ее эффективного функционирования;

- обеспечению ее эффективного развития.

Задачи формирования и развития предпринимательской сети входят в число задач, решаемых в рамках стратегического менеджмента.

Задача по обеспечению эффективного функционирования сформированной предпринимательской сети является задачей оперативного планирования и регулирования.

Для учета интересов всех участников предпринимательской сети (реальных или потенциальных) необходимо разработать общую стратегию ее развития.

Представляется, что для всех участников предпринимательской сети (реальных или потенциальных) целесообразно использовать двухуровневую модель ее регулирования. Первый уровень, базовый должен реализовываться руководством бизнес - единицы, связи с разработкой локальных планов ее развития и обоснованием целей интегрированного развития данного сетевого партнера, а также определением путей, методов, ресурсов, необходимых для достижения этих целей.

Второй уровень связан с анализом, координации, уточнением отдельных локальных стратегических планов сетевых партнеров, с анализом сочетаемости их целей, возможностей, ресурсов и разработкой общего комплексного плана.

Тогда, в качестве базового инструмента регулирования развития предпринимательской сети целесообразно использовать две разновидности бизнес - плана:

- локальный бизнес-план бизнес-единицы, выступающей в роли сетевого партнера;

- комплексный бизнес-план предпринимательской сети. 
В локальном бизнес - плане обосновываются: цели, задачи стратегического развития, пути их достижения в рамках сетевого партнерства, мероприятия, необходимые для достижения поставленной цели, ожидаемого эффекта. В целом подход к разработке локального бизнес - плана, перечень и содержание основных разделов соответствует современным подходам и рекомендациям. В то же время он разрабатывается как обоснование путей и методов интеграционного развития бизнес - единицы на основе взаимодействия с сетевым партнером, на основе формирования условий для получения синергетического эффекта.

Управленческие функции второго уровня должны реализовываться исходя из особенностей (разновидности) конкретной предпринимательской сети:

- либо временным коллективным органом (советом) представителей сетевых партнеров;

- либо отдельными управленческими структурными подразделениями различных сетевых партнеров, которым делегируются соответствующие полномочия;

- либо отдельными специалистами - консультанты и организации, привлекаемыми для этой работы;

- возможен и смешанный вариант.

В комплексном бизнес - плане развития предпринимательской сети происходит взаимоувязка целей сетевых партнеров, путем их достижения возможностей оптимизации их потенциалов и совместного использования их ресурсов. На втором высшем уровне уточняются, корректируются локальные бизнес - планы в сторону наилучшего взаимодействия сетевых партнеров, и более полного учета возможностей решения их проблем и использование возможностей. На этом уровне уточняются виды и формы взаимосвязей и взаимодействия между конкретными участниками предпринимательской сети. В процессе разработки комплексного бизнес - плана показатели отдельных сетевых партнеров могут уточняться и изменяться, как в большую, так и в меньшую сторону. Возможны варианты, когда проработка комплексного бизнес - плана предпринимательской сети показывает такую низкую эффективность какой либо бизнес - единицы, что ее вхождение в данную предпринимательскую сеть становится не целесообразным.

Модель двухуровневого стратегического управления развитием предпринимательской сети представлена на рис.4.4.

Рассмотрим более подробно основные блоки стратегического управления развитием предпринимательской сети.

Блок 1.1 включает:

- анализы проблем, возникающих перед бизнес - единицами под воздействием внешней и внутренней среды;

- формирование перспективных целей стратегического развития, анализа возможности их достижения в рамках предпринимательской сети:

- обоснование комплекса мероприятий бизнес - плана, реализация которых обеспечит достижение стратегических целей;

- составление проектного варианта локального бизнес - плана для конкретной бизнес - единицы, выступающей в роли сетевого партнера. 


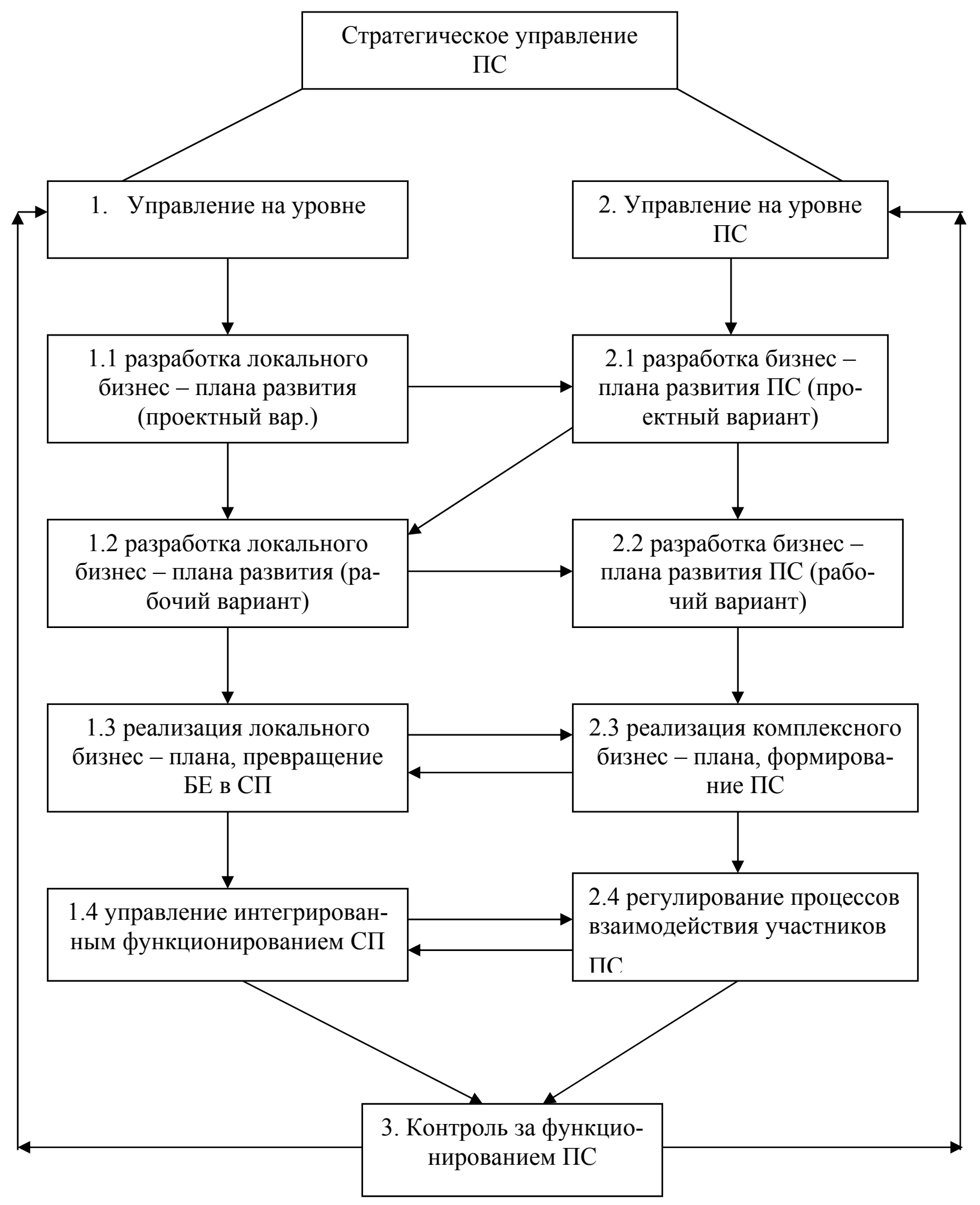

Рисунок .4.4 -. Модель двухуровневого управления созданием (развитием) предпринимательской сети (ПС)

Условные обозначения:

БЕ - бизнес-единица

СП - сетевой партнер

ПС - предпринимательская сеть 
Более детально, подходы к анализу внешней и внутренней среды бизнес партнеров были, рассмотрены выше (см. раздел 2.1; 2.2). На основе анализа выясняются проблемы и возможности бизнес - единиц.

Проектный вариант основан на учете в первую очередь собственных интересов и возможностей бизнес - единицы и на гипотезе, предположении о возможностях и готовности потенциального партнера к интеграции в ПС.

Проектный (желательный) вариант передается для согласования и разработки комплексного бизнес - плана (его проектного варианта) предпринимательской сети партнерам (или временному коллективному органу, управленческому подразделению, организации, которой поручена проектная координация стратегических планов).

Блок 2.1 предусматривает: рассмотрение локальных бизнес - планов на их сочетаемость; формирование и анализ вариантов взаимодействия сетевых партнеров; отбор наиболее предпочтительных; корректировка; составление проектного варианта комплексного бизнес - плана и анализ его эффективности.

Блок 1.2 предусматривает рассмотрение полученной от блока 2.1 информации о реальных возможностях взаимодействия с сетевыми партнерами, уточнения решений, мероприятий, т. е. проектного варианта, и превращение его в рабочий проект.

Блок 2.3 предусматривает интеграцию локальных рабочих вариантов в единый комплексный рабочий бизнес - план развития предпринимательской сети.

На этом этапе обосновываются значения целевых показателей развития предпринимательской сети в целом, которые должны быть достигнуты после реализации бизнес - плана ее развития.

Блок 1.3 содержит действия по реализации локального бизнес - плана сетевого партнера, являющегося частью комплексного бизнес - плана развития всей сети. На этом этапе реализуются мероприятия бизнес - плана: предоставляются для взаимного пользования элементы потенциала, происходит определенное изменение специализации, углубляется разделение и кооперация труда и т. д. По сути дела именно на этом этапе бизнес - единица превращается в сетевого партнера.

Данные о ходе реализации процедур Блока 1.3 поступают:

- в блок 2.3 корректировки взаимосвязанных работ при реализации локальных бизнес - планов сетевых партнеров и для общего анализа хода реализации комплексного бизнес - плана сети;

- в блок 1.4 для оперативных действий по осуществлению бизнес - процессов.

Данные о ходе реализации комплексного бизнес - плана из блока 2.3 используются для уточнения хода реализации локального бизнес - плана и обеспечения сопоставимости локальных составляющих комплексного плана.

В результате реализации локального бизнес - плана бизнес - единица превращается в сетевого партнера.

Блок 1.4 включает процедуры управления процессом взаимодействия сетевого партнера с другими участниками предпринимательской сети. Данные о ходе этих 
процессов, поступают к блоку 2.4 , в котором собирается и, анализируется информация обо всех интеграционных процессах в сети. В нем могут вырабатываться управленческие решения о корректировке во времени и пространстве потоков от одного сетевого партнера к другому, т. е. управленческие воздействия, направленные обратно к блоку 1.4.

В блоках 1.4 и 2.4 формируется информация, характеризующая качество, функционирование, как отдельных сетевых партнеров, так и предпринимательской сети в целом. Она поступает в блок 3, где анализируется эффективность реализуемых планов и при значительном их отклонении от плановых вырабатывается информация, импульс по пересмотру и корректированию реализуемых локальных и комплексных планов развития предпринимательской сети.

Успех стратегического регулирования предпринимательской сети связан не только с качеством разработки стратегических планов ее формирования (бизнес планов), но и с качеством их реализации. После определения стратегических целей должны формироваться оперативные задачи, обеспечивающие их достижение. При этом должен соблюдаться принцип конгруэнтности (соответствия). Оперативные цели, вырабатываемые на высшем уровне на достаточно продолжительный период, должны разбиваться на конкретные задачи, которые должны реализовываться структурными подразделениями и исполнителями в определенные сроки (как правило, они дифференцируются до сменных и дневных заданий)'.

Оперативное регулирование предпринимательских сетей осуществляется с целями:

- реализации комплексного и локального бизнес - планов по формированию предпринимательской сети;

- эффективного текущего взаимодействия сетевых партнеров в процессе их функционирования.

Цели стратегического уровня: имеют отношение к организации в целом; являются общими (не детализированными); определяют политику организации.

Цели оперативного уровня: имеют прямое отношение к деятельности конкретной структуры (подразделения) организации; должны быть детально проработаны, должны соответствовать целям организации.

Одним из инструментов, обеспечивающих достижение стратегической цели формирования предпринимательской сети, является оперативное календарное планирование работ по реализации комплексного и локального бизнес - планов ее формирования.

Основой оперативного управления формированием предпринимательской сети, т. е. реализацией комплексного бизнес - плана является целевая комплексная программа. Она представляет собой директивный и адресный документ, увязывающий действия всех участников предпринимательской сети (сетевых партнеров), т. е. разных организаций и лиц соисполнителей по срокам выполнения этапов работ, их последовательности и ресурсам. Более детально действия отдельных сете-

${ }^{1}$ Асаул А. Н., Иванов С. Н. Актуальность создания и эффективное управление корпоративными строительными структурами петербургского региона / Международная академия менеджмента. Научн. тр. Вып. IV. М., 2003. Кабаков В. С, Шатрова E. В. Стратегия предпринимательства. - СПб.: СПбГИЭА, 1996. 
вых партнеров, их подразделений и сотрудников должно регулироваться локальным оперативным календарным планом данной организации.

Задачи оперативного планирования и регулирования функционирующей ПС так же является двухуровневым:

- на 1-ом уровне (бизнес - единицы) разрабатывается и реализуется оперативный график прохождения в пространстве и времени всех видов потоков, входящих и исходящих от данного сетевого партнера;

- на 2-ом уровне (предпринимательской сети) осуществляется контроль, координация, всех видов потоков между всеми сетевыми партнерами данной сети.

Организация оперативного управления предпринимательской сети предусматривает выделение специальных плановых органов (планово - диспетчерского бюро, отдела) или работников, занимающихся плановыми расчетами.

Инструментарий, необходимый для успешного функционирования двухуровневой модели регулирования процессов создания и развития предпринимательской сети приводится в табл.4.2.

Таблица 4.2 - Основной инструментарий формирования и развития предпринимательской сети

\begin{tabular}{|c|c|c|c|c|}
\hline & Вид документа & Назначение & $\begin{array}{l}\text { Содержание, ха- } \\
\text { рактер использова- } \\
\text { ния }\end{array}$ & $\begin{array}{l}\text { Уровень и особенности } \\
\text { использования }\end{array}$ \\
\hline 1 & 2 & 3 & 4 & 5 \\
\hline 1 & $\begin{array}{l}\text { Целевая комплекс- } \\
\text { ная программа со- } \\
\text { здания (развития) } \\
\text { предприниматель- } \\
\text { ской сети }\end{array}$ & $\begin{array}{l}\text { Стратегическое } \\
\text { управление дея- } \\
\text { тельностью по } \\
\text { формированию } \\
\text { предприниматель- } \\
\text { ской сети }\end{array}$ & $\begin{array}{l}\text { Директивный, ад- } \\
\text { ресный документ, } \\
\text { увязывающий дей- } \\
\text { ствия всех бизнес- } \\
\text { единиц, входящих } \\
\text { в предпринима- } \\
\text { тельскую сеть по } \\
\text { срокам, ресурсам и } \\
\text { т. д. }\end{array}$ & $\begin{array}{l}\text { Разрабатывается сов- } \\
\text { местно представителя- } \\
\text { ми всех сетевых партне- } \\
\text { ров (или по их поруче- } \\
\text { нию) }\end{array}$ \\
\hline 2 & $\begin{array}{l}\text { Комплексный биз- } \\
\text { нес - план созда- } \\
\text { ния (развития) се- } \\
\text { тей }\end{array}$ & $\begin{array}{l}\text { Проработка слож- } \\
\text { ных организацион- } \\
\text { но - технических } \\
\text { вопросов взаимо- } \\
\text { действия сетевых } \\
\text { партнеров }\end{array}$ & $\begin{array}{l}\text { Обоснование } \\
\text { направления мето- } \\
\text { дов совместного } \\
\text { использования по- } \\
\text { тенциалов } \\
\text { скольких сете } \\
\text { партнеров }\end{array}$ & $\begin{array}{l}\text { Разрабатывается сов- } \\
\text { местно специалистами } \\
\text { заинтересованных сете- } \\
\text { вых партнеров (или по } \\
\text { их поручению). }\end{array}$ \\
\hline 3 & $\begin{array}{l}\text { Локальные бизнес } \\
- \text { планы сетевых } \\
\text { партнеров } \\
\text { Оптимизация па- } \\
\text { раметров бизнес - } \\
\text { единицы при ее } \\
\text { вхождении в пред- } \\
\text { принимательскую } \\
\text { сеть }\end{array}$ & $\begin{array}{l}\text { Модернизация биз- } \\
\text { нес - единицы при } \\
\text { eе вхождении в } \\
\text { предприниматель- } \\
\text { скую сеть }\end{array}$ & $\begin{array}{l}\text { Обоснование } \\
\text { роприятий, } \\
\text { рые должны быть } \\
\text { реализованы кон- } \\
\text { кретной бизнес - } \\
\text { единицей для ее } \\
\text { функционирования } \\
\text { в составе пр. с. }\end{array}$ & $\begin{array}{l}\text { Разрабатывается руко- } \\
\text { водством и специали- } \\
\text { стами бизнес - единиц }\end{array}$ \\
\hline 4 & $\begin{array}{l}\begin{array}{l}\text { Календарный план } \\
\text { создания }\end{array} \text { (разви- } \\
\end{array}$ & $\begin{array}{l}\text { Оперативное } \\
\text { управление реали- }\end{array}$ & $\begin{array}{l}\text { Выделение отдель- } \\
\text { ных исполнителей, }\end{array}$ & $\begin{array}{l}\text { Координирующий орган } \\
\text { или какая - либо струк- }\end{array}$ \\
\hline
\end{tabular}




\begin{tabular}{|c|c|c|c|c|}
\hline & $\begin{array}{l}\text { тия) предпринима- } \\
\text { тельской сети }\end{array}$ & $\begin{array}{l}\text { зацией программ и } \\
\text { бизнес - плана }\end{array}$ & $\begin{array}{l}\text { их задач, этапов } \\
\text { работ их последо- } \\
\text { вательность, сроки } \\
\text { и ресурсы }\end{array}$ & $\begin{array}{l}\text { тура, которой поручено } \\
\text { осуществлять оператив- } \\
\text { ные регулирования }\end{array}$ \\
\hline 5 & $\begin{array}{l}\text { Оперативный ло- } \\
\text { кальный календар- } \\
\text { ный план }\end{array}$ & $\begin{array}{l}\text { Оперативное } \\
\text { управление, выпол- } \\
\text { нение локального } \\
\text { бизнес - плана (мо- } \\
\text { дернизации бизнес } \\
\text { - единицы) }\end{array}$ & $\begin{array}{l}\text { Указание задач, } \\
\text { исполнители ре- } \\
\text { сурсов, сроков, мо- } \\
\text { дернизации бизнес } \\
\text { - единицы }\end{array}$ & $\begin{array}{l}\text { Выполняется руководи- } \\
\text { телем и специалистами } \\
\text { конкретной бизнес - } \\
\text { единицы }\end{array}$ \\
\hline
\end{tabular}

При разработке локальной стратегии сетевых партнеров целесообразно использовать методы SWOT - анализа, анализа сетевых цепочек, анализа.

В ходе анализа внутренних факторов необходимо изучить портфель производственных и рыночных интересов бизнес - единицы использовать матрицу БКГ и т. д.

Может быть использован инструментарий маркетинга взаимодействия, который позволяет достигать высоких производственно-рыночных результатов на инвестиционном рынке, рынке недвижимости, различных видах товарных рынков.

В процессе создания и развития предпринимательской сети необходимо использовать метод контроллинга. Он представляет собой завершающую стадию планово - управленческого цикла. Его задачей является не только контроль за выполнением плановых показателей, не только сопоставление результатов и целей, но и анализ внешних условий, рыночной коньюктуры, сложившейся на момент контроллинга. По сути дела происходит объединение процедуры контроля и процедуры анализа рынка, что может стать началом нового этапа планового управленческого цикла. Контроллинг направлен на развитие объекта, на отслеживание новых возможностей и их своевременное использование.

В соответствии с вышесказанным можно выделить следующие основные принципы регулирования создания и развития предпринимательских сетей являются:

- сочетаемость целей всех участников - сетевых партнеров;

- обеспечение взаимного интереса всех участников в результате деятельности;

- учет специфики сетевых партнеров и особенностей их интеграции;

- единство стратегических целей и тактических задач;

- проектная проработка и обоснованность решений по ее функционированию;

- коллективное участие в принятии решений касающихся всех сетевых партнеров;

- наличие координационных (ого) центров обеспечивающих согласованность действий и решений;

- добровольное вхождение в предпринимательскую сеть на взаимовыгодных основах;

- обязательное и своевременное выполнение взятых на себя обязательств, соответствующих принятым планам;

- обратная связь, непрерывность и своевременность реакций на изменения внутренней и внешней среды. 


\section{ГЛАВА 5 \\ МЕТОДОЛОГИЧЕСКИЕ ОСНОВЫ ОРГАНИЗАЦИИ ПРЕДПРИНИМАТЕЛЬСКИХ СЕТЕЙ}

\section{1. Диагностика предпосылок к сетевой интеграции}

Одной из первых процедур по формированию предпринимательской сети является обоснование целесообразности интеграционного функционирования бизнес-единицы. Необходимо выявить наличие предпосылок к совместной деятельности нескольких предприятий, их превращению в сетевых бизнес-партнеров.

Предпосылки, т.е. предварительные условия к созданию предпринимательской сети возникают под воздействием внешней и внутренней среды, в процессе эволюции взглядов, отношений, целей, системы ценностей человека ${ }^{1}$.

Во временном плане можно говорить о возникновении предпосылок, об их усилении, укреплении их созревания и о их затухании.

В текущем управлении они рассматриваются в статике, в данном временном разрезе, в среднесрочном и в долгосрочном менеджменте необходимо учитывать и прогнозировать скорость и направление их изменений.

Анализ функционирования системы предпринимательства показал, что в качестве базовых предпосылок к созданию предпринимательской сети могут быть выделены следующие факторы: личностно-психологические, социальные, экономические, организационные.

Личностно-психологические предпосылки заключаются: в стремлении менеджера-предпринимателя усилить свой управленческий потенциал; реализовать мотивацию к разделению ответственности; в способности учитывать нужное мнение и работать в команде.

Социальные предпосылки связаны с особым состоянием внешней среды бизнеса: потребностью защиты своего бизнеса от конкурентов; потребностью защиты от криминала; потребностью отстаивать свои интересы перед органами власти и т.д.

Экономические предпосылки связаны с проблемами: выживаемости, экономического роста, финансовой устойчивости, усилении конкуренции и т.д. В условиях инвестиционно-строительного рынка важнейшими из них являются: сохраняющаяся ограниченность инвестиционных ресурсов; дифференциация конкурентной среды, связанная с ростом числа малых и средних предприятий, усложнением конкурентных отношений между крупными объединениями; увеличение спроса в некоторых рыночных сферах (например, в жилищном строительстве); увеличение взаимодействия между реально функционирующими бизнес-

${ }^{1}$ Головина A. Н. Методология разработки проблемы специализации и кооперации, производства в условиях трансформируемой экономики // Известия Уральского университета, 1999. $3 a-$ белин П. В. Основы стратегического управления. - М.: Информационно-внедренческий центр «Маркетинг», 1998. 
субъектами и органами государственного (в частности, градостроительного) регулирования.

Организационные предпосылки связаны с: существованием подходящих, адекватных потенциальных партнеров; возможностями осуществления информационных и транспортных обменов; территориальным расположением и доступностью объектов и т.д.

Структура базового комплекса предпосылок к созданию предпринимательской сети представлена на рис.5.1.

Базовые предпосылки могут рассматриваться как набор в той или иной степени агрегированных элементов (элементарных предпосылок), т.е. можно говорить о полнообъемных базовых предпосылок и о их элементарных составляющих.

У каждой конкретной бизнес-единицы может быть: весь комплекс полнообъемных предпосылок к созданию предпринимательской сети; частичный набор полнообъемных предпосылок; наличие одной или нескольких предпосылок элементарных. Очевидно, что наличие комплекса полнообъемных предпосылок свидетельствует о высокой степени целесообразности вхождения бизнес-единиц в предпринимательскую сеть.

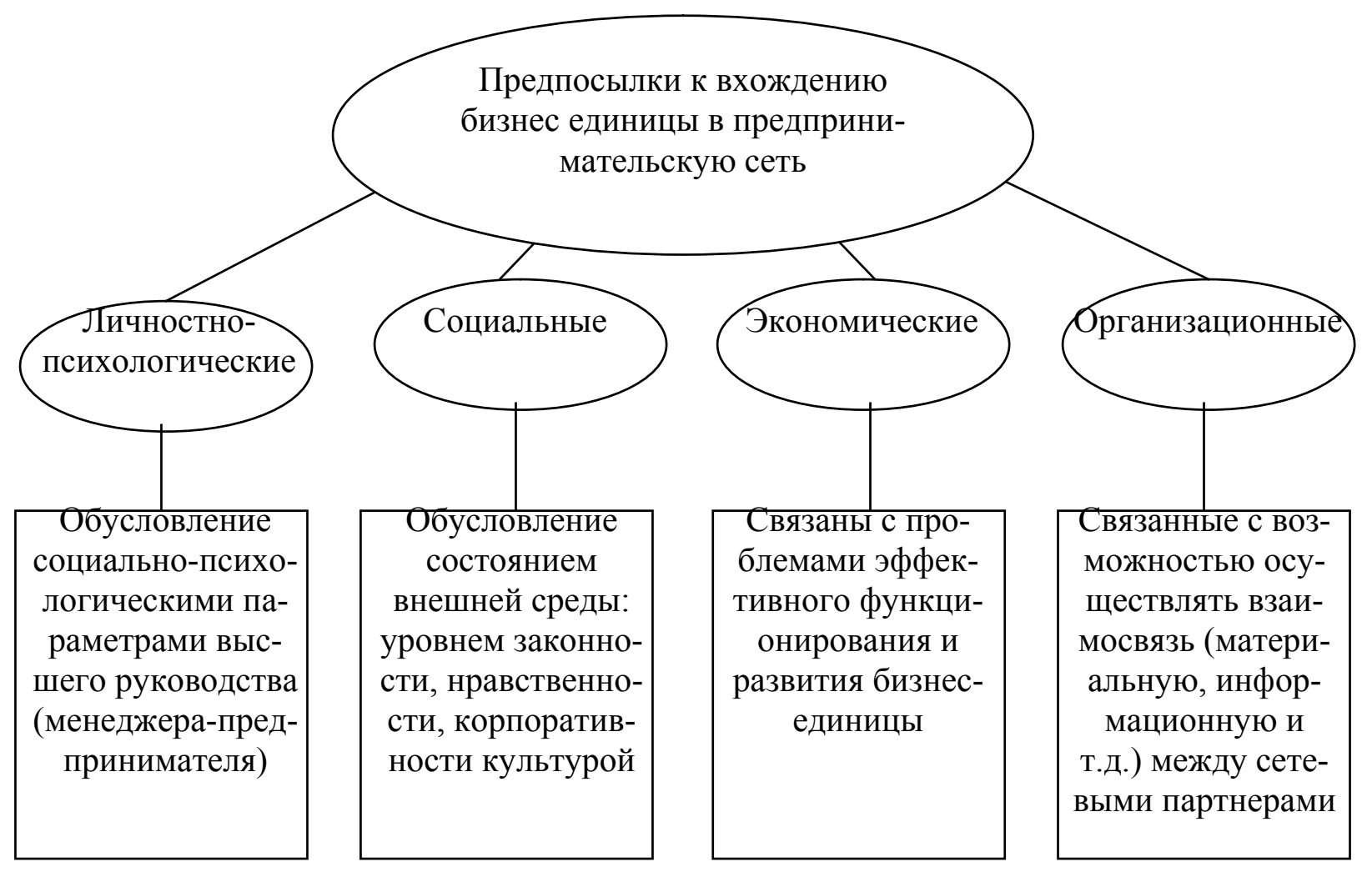

Рисунок.5.1.- Базовые предпосылки к созданию предпринимательской сети

Система оценки предпосылок к интеграционному взаимодействию включает:

- индивидуальную оценку силы каждой элементарной предпосылки (Эп);

- интегрированную оценку каждой базовой предпосылки (Б пі);

- общую оценку предпосылок к созданию предпринимательской сети (ППС). 
Каждую элементарную предпосылку предлагается оценивать как: отсутствие (0 балла); слабую (1 балл); среднюю (2 балла); сильную (3 балла). "Сила" каждой базовой предпосылки $\left(Б_{\text {пi }}\right)$ может оцениваться суммой баллов входящих в нее элементарных предпосылок.

Может быть использована и более дифференцированная балльная оценка в зависимости от конкретных условий, в которых осуществляется оценивание. При этом остается неизменным общий подход к оценке - использование экспертного метода. При этом важно иметь ввиду, что точность экспертного метода зависит не от широты "шкалы", а от степени корректности в реализации экспертного метода. Если экспертный метод реализуется в условиях однозначности вопросов, репрезентативности выбора экспертов и использования принципа независимости суждений, он обеспечивает получение достаточно корректных результатов.

Общая оценка предпосылок, имеющихся у бизнес-единицы для вхождения в предпринимательскую сеть дается как набором показателей силы базовых предпосылок, так и общей суммой баллов, входящих в нее элементов.

Оценивать предпосылки вхождения бизнес-единицы в предпринимательскую сеть целесообразно на основе:

1. Отбора и анализа данных о социально-психологическом состоянии и предпочтениях руководителя (владельца) бизнес-единицы.

2. Сбора и анализа данных о социально-ориентированных опасностях внешней среды (и ее тенденции).

3. Сбора и анализа данных, характеризующих основные техникоэкономические показатели бизнес-единицы, ее экономические результаты (и ее тенденции).

Необходимо подчеркнуть, что введение социально-психологических характеристик обусловлено ориентацией на социально-психологическую сущность предпринимательства, которое основывается на личностных качествах и инициативе руководителей, превращающих традиционные производственно-хозяйственные процессы в предпринимательские.

Данные о личностных социально-психологических параметрах высшего руководства (владельцев) бизнес-единицы можно получить на основе использования достаточно проработанных методиках тестирования как самостоятельно, так и привлекая психологов-консультантов ${ }^{1}$. Результаты анализа должны интерпретироваться руководством бизнес-единицы (экспертами), которые дают балльную оценку силы данной базовой предпосылки.

Для оценки социальных предпосылок к вхождению в предпринимательскую сеть собираются данные на основе опросов, тестов, анализа статистических данных, собственного опыта, характеризующих внешние опасности плана, связанного с нарушением договоров, этических норм и правил и т.д.

При анализе внешней среды можно пользоваться методами маркетинга и SWOT-анализа. Для оценки каждого отдельного элемента данной базовой пред-

${ }^{1}$ Куприянова И. В., Михайлушкин А. И. Об особенностях предпринимательской деятельности в строительстве. Экономическая политика в области жилищного строительства в условиях рыночных отношений. - СПб.: СПбГИЭА, 1994. 
посылки целесообразно разрабатывать специальный вопросник (анкету) ${ }^{1}$.

Анализ данных, характеризующих экономические предпосылки к интеграционному поведению целесообразно проводить на основе наблюдений: за динамикой деловых и финансовых показателей, бизнес-единицы и за параметрами внешней среды, оказавшим на ее деятельность непосредственное влияние. Так к неблагоприятным экономическим тенденциям относятся: снижение прибыльности, ухудшение показателей ликвидности, финансового состояния показателей оборачиваемости, рентабельности. Значимость каждого показателя в зависимости от жизненного цикла фирмы разная. Так, на этапе зарождения фирмы особое внимание должно уделяться показателям ликвидности и финансовым показателям. На этапе ускорения роста, финансовые показатели и показатели роста должны быть стабильны. Здесь более важным становится отслеживание показателей оборачиваемости, чем выше, тем лучше идут дела фирмы. Его уменьшение требует анализа и применения специальных мер. На этапе замедления роста конкурентного преимущества наиболее ответственным является анализ рентабельности продаж, а при достижении зрелости особое внимание должно уделяться рентабельности капитала. На этапе спада происходит дестабилизация всех показателей экономической и деловой активности. На основании анализа этих показателей (в частности рентабельности) можно сделать вывод о возможности или невозможности традиционного направления функционирования данной бизнес-единицы и о наличии предпосылок для ее интегрированного функционирования в составе предпринимательской сети.

Отслеживание экономических показателей бизнес-единицы должно приводится на основе систематического анализа внутренней и внешней среды на основе маркетингового исследования, контроллинга и внутрифирменного экономического анализа.

Анализ организационных предпосылок проводится на основе анализа некоторых элементов внешней среды. Так наличие потенциальных партнеров к общему сосуществованию в составе предпринимательской сети выявляется в процессе жизнедеятельности фирмы и базируется на формировании в течении определенного времени партнерских деловых, доброжелательных и полезных контактов между самостоятельными бизнес-единицами. В то же время бизнес-субъекты одной предпринимательской сети должны формировать взаимные материальные, ресурсные, информационно-коммуникативные потоки, поэтому к предпосылкам для реализации этих потребностей должно быть их территориальное расположение, не затрудняющее необходимые контакты. Кроме этого необходима развитая транспортная сеть для организации материальных потоков и эффективная информационная система, обеспечивающая своевременные коммуникации в требуемом объеме.

Логически алгоритм процесса анализа и оценки предпосылок для вхождения бизнес-единицы в предпринимательскую сеть приводится на рис.5.2.

${ }^{1}$ Асаул А. Н., Денисова И. В. Интеграция строительных фирм в форме сетевых индустриальных организаций Регион: политика, экономика, социология», №1, СПб., 2001. 


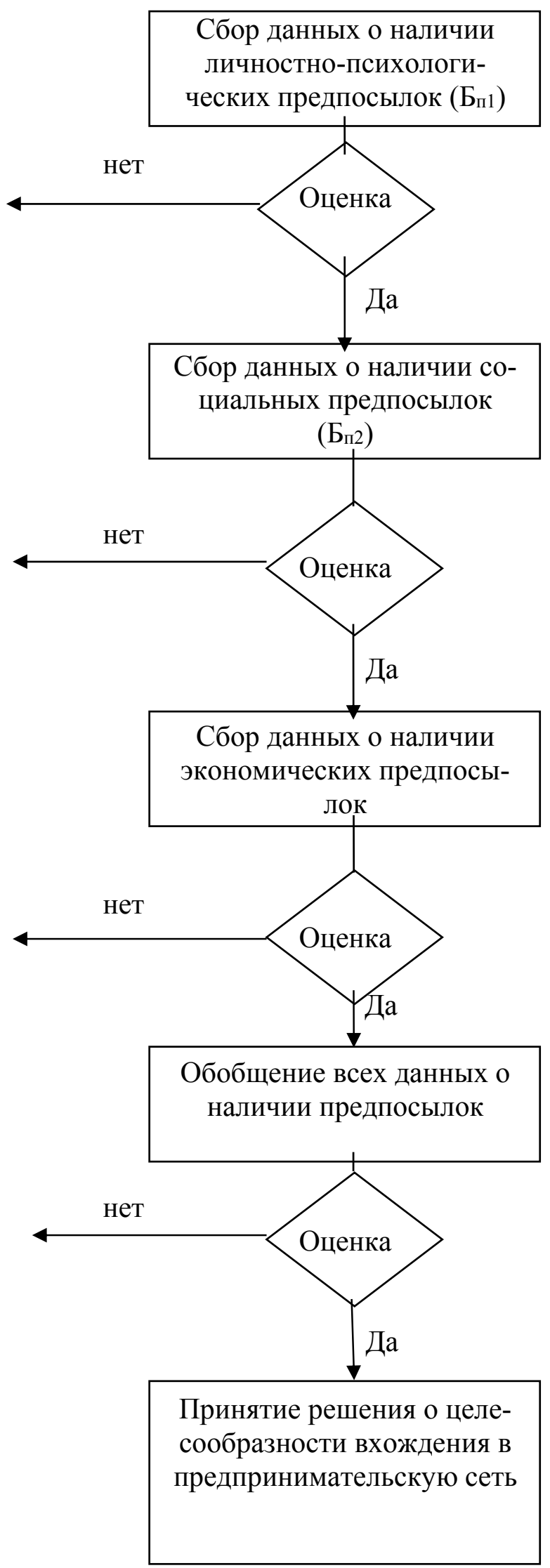

Рисунок.5.4.- Логический алгоритм процесса оценки предпосылок для вхождения бизнес-единицы в предпринимательскую сеть

Пример оценки предпосылок к вхождению бизнес-субъекта в предпринима- 
тельскую сеть приводится в табл.5.1.

При полном отсутствии базовых и элементарных предпосылок к интеграционному функционированию вхождение данной единицы в предпринимательскую сеть противопоказано.

При отсутствии отдельных базовых и(или) элементарных предпосылок к интеграционному функционированию необходим анализ конкретных условий и конкретных обстоятельств деятельности бизнес-единицы.

Рассмотрим методы анализа предпосылок к интеграционному функционированию. Для этого по каждой базовой предпосылке предлагается ввести набор показателей, оценивающих ее значимость.

Таблица 5.1-Оценка предпосылок к интеграционному функционированию

\begin{tabular}{|c|c|c|c|c|c|c|}
\hline $\begin{array}{l}\text { № } \\
\Pi / \Pi\end{array}$ & Предпосылки & & \multicolumn{3}{|c|}{$\begin{array}{c}\text { Оценка } \\
\text { предпосылок }\end{array}$} & $\begin{array}{c}\text { Методы сбора } \\
\text { информации }\end{array}$ \\
\hline 1. & 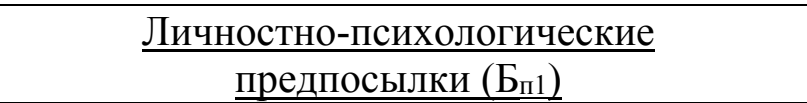 & & & & & \multirow{5}{*}{$\begin{array}{l}\text { Использование } \\
\text { психологиче- } \\
\text { ских тестов и } \\
\text { вопросников }\end{array}$} \\
\hline & 1.1. Стремление к сотрудничеству & $\ni^{\Pi_{1.1}}$ & 0 & & & \\
\hline & 1.2. Уровень коммуникабельности & $\ni^{\Pi_{1.2}}$ & & & 3 & \\
\hline & 1.3. Уровень бесконфликтности & $\ni^{\Pi_{1.3}}$ & & 1 & & \\
\hline & 1.4. Уровень культуры и нравственности & $\ni^{\Pi_{1.4}}$ & & & 3 & \\
\hline \multirow[t]{4}{*}{2.} & Социальные предпосылки (Бп2) & & & & & \\
\hline & 2.1. Потребность в защите (физическая) & $\ni^{\Pi_{2.1}}$ & 1 & & & \multirow{3}{*}{$\begin{array}{l}\text { 1. Опрос руко- } \\
\text { водства } \\
\text { 2. пользование } \\
\text { тестов } \\
\text { 3. Анализ прак- } \\
\text { тики функциони- } \\
\text { рования }\end{array}$} \\
\hline & $\begin{array}{l}\text { 2.2. Потребность в отстаивании деловых } \\
\text { (групповых) интересов }\end{array}$ & $\ni^{\Pi_{2.2}}$ & & & 3 & \\
\hline & $\begin{array}{l}\text { 2.3. Потребность в защите от недобросо- } \\
\text { вестных партнеров, конкурентов }\end{array}$ & $\ni^{\Pi_{2.3}}$ & & 2 & & \\
\hline \multirow[t]{5}{*}{3.} & Экономические предпосылки (Бп3) & & & & & \multirow{5}{*}{$\begin{array}{l}\text { 1. Анализ эко- } \\
\text { номических по- } \\
\text { казателей пред- } \\
\text { приятия в дина- } \\
\text { мике } \\
2 . \text { Анализ внеш- } \\
\text { них угроз }\end{array}$} \\
\hline & $\begin{array}{l}\text { 3.1. Ухудшение экономических показате- } \\
\text { лей }\end{array}$ & $\ni^{\Pi_{3.1}}$ & 0 & 1 & - & \\
\hline & $\begin{array}{l}\text { 3.2. Желание улучшить экономические по- } \\
\text { казатели }\end{array}$ & $\ni^{\Pi_{3.2}}$ & 0 & - & 2 & \\
\hline & 3.3. Усиление конкуренции & $\ni^{\Pi_{3.3}}$ & - & - & 3 & \\
\hline & 3.4. Развитие предприятия & $\ni^{\Pi_{3.4}}$ & - & 2 & - & \\
\hline \multirow[t]{4}{*}{4.} & Организационные предпосылки (Б Б & & & & & \\
\hline & $\begin{array}{l}\text { 4.1. Наличие потенциальных партнеров } \\
\text { нужного профиля (специализации) }\end{array}$ & $\ni^{\Pi_{4.1}}$ & & & 3 & $\begin{array}{l}\text { Маркетинговые } \\
\text { исследования }\end{array}$ \\
\hline & $\begin{array}{l}\text { 4.2. Территориально-транспортная доступ- } \\
\text { ность потенциальных партнеров }\end{array}$ & $\ni^{\Pi_{4.2}}$ & & 2 & & $\begin{array}{l}\text { Анализ внешней } \\
\text { среды }\end{array}$ \\
\hline & $\begin{array}{l}\text { 4.3. Возможности эффективных информа- } \\
\text { ционно-коммуникационных связей }\end{array}$ & $\ni^{\Pi_{4.3}}$ & & 2 & & $-"-$ \\
\hline
\end{tabular}

Если предпосылки слабые и не имеют тенденции к усилению, то очевидно нет явной целесообразности к вхождению в предпринимательскую сеть.

Если предпосылки средние или(и) сильные имеют тенденцию к усилению, то возникает сильная целесообразность к вхождению в предпринимательскую сеть. 
В качестве ведущих базовых предпосылок можно выделить экономические и социальные, так как они связаны с достижениями основных целей бизнеса: экономической эффективностью, выживанием и развитием.

Поэтому если экономические и (или) социальные предпосылки сильные и (или) имеют тенденцию к усилению, то целесообразно рассматривать варианты вхождения в предпринимательскую сеть, при этом разрабатывая дополнительно комплекс мероприятий по активизации слабых элементов комплекса базовых предпосылок.

\section{2. Разработка программ формирования предпринимательской сети и оценка ее эффективности}

Любое стратегическое решение о вхождении бизнес-единицы в предпринимательскую сеть должно:

- иметь необходимые для этого предпосылки (см. § 3.2);

- быть научно проработанным и проектно обоснованным;

- реализуемым на практике.

Формирование стратегических управленческих решений целесообразно осуществлять на основе широко апробированного программно-целевого метода. Этот метод базируется на разработке ряда системных моделей, важнейшими из которых (в соответствии с положениями теории социально-экономического планирования и прогнозирования) являются: концепция, стратегия, программа, план. В качестве основной модели принято использовать целевые программы, которые в контексте исследуемой тематики следует рассматривать как программы формирования предпринимательских сетей.

В рамках таких программ должна разрабатываться совокупность планов, структурированных в соответствии с целями и задачами программы и нуждающихся в соответствующем организационном обеспечении.

Проработка стратегического решения о вхождении бизнес-единицы в предпринимательскую сеть должна осуществляться в виде:

- локального бизнес-плана сетевого партнера (ЛБПСП);

- комплексного бизнес-плана предпринимательской сети (КБППС), интегрального, консолидирующего и увязывающего все локальные бизнес-планы.

Локальный бизнес-план сетевого партнера (ЛБПСП) должен содержать совокупность научно-обоснованных решений (оргтехмероприятий) по передаче на основе кооперации отдельных видов своей производственно-хозяйственной деятельности другому (другим) участникам предпринимательской сети; по включению отдельных дополнительных видов (объемов) работ, получаемых от сетевых партнеров; по трансформации отдельных элементов своего потенциала с учетом реализуемых мероприятий; по внесению отдельных необходимых элементов в систему управления бизнесом и в практику менеджмента; по экономическому обоснованию ожидаемых расходов, доходов и эффективности. 
Исходными данными по разработке ЛБПСП является техническое задание, базирующееся на результатах диагностики предпосылок к вхождению в предпринимательскую сеть. Задачей составления ЛБПСП является осознание, понимание и обоснование путей достижения цели интегрированного функционирования бизнес-субъекта. Он позволяет конкретизировать общий широкий подход и провести и довести стадию теоретического осмысливание до конкретного проектирования необходимых мероприятий, уяснить и учесть взаимозависимость и взаимосвязи всех трансформируемых элементов локальной производственной системы и достаточно полено учесть ожидаемые затраты и результаты.

В любом случае ЛБПСП должен дать четкое, научно обоснованное определение для чего, как входит бизнес-субъект в предпринимательскую сеть, каким образом, с помощью реализации каких мероприятий и каких целей желаемая цель будет достигнута.

В зависимости от масштабов бизнес-единицы, от ее организационнотехнической сложности, от стоящей перед нею проблем структуры ЛБПСП, степень детализации расчетов, его содержание будет различно.

При разработке КБППС необходимо:

- зафиксировать миссию сети, цели ее деятельности, цели, которые должны служить критериями принятых решений (долго, средне и краткосрочные);

- сформулировать конкретные задачи сети, которые необходимо решать для достижения целей сетевых партнеров;

- сбалансировать цели мероприятий, ресурсы всех участников предпринимательской сети;

- оптимизировать на основе кооперации и специализации потенциал всех сетевых партнеров;

- обосновать плановые показатели, функционирование предпринимательской сети.

Комплексный бизнес-план сети должен содержать:

1. Краткую характеристику всех участников предпринимательской сети.

2. Скоординированный, укрупненный план основных мероприятий по кооперации и специализации планируемой внутри сети, фиксирующий взаимные обязательства сторон.

3. Основные принципы (схемы) управления совместной производственнохозяйственной деятельностью сети.

4. Перечень необходимых расчетно-финансовых и организационно-правовых документов.

Рассмотрим более подробно методы составления локального бизнес-плана сетевого партнера.

Исходными данными для проектирования являются: техническое задание (Т3); основные технико-экономические показатели соответствующей бизнес-единицы ${ }^{1}$.

Техническим заданием на разработку локального бизнес-плана сетевого партнера служат результаты диагностики предпосылок к интеграционному взаимо-

${ }^{1}$ Серов В. М. Управление строительством в России: Каким ему быть? / Экономика строительства №10, 2001. Якутии Ю. Концептуальный подход к оценке эффективности корпоративной интеграции / Российский журнал №5, 1998. 
действию бизнес-субъектов. Они очерчивают определенный круг требований, который должны будут соответствовать сетевые партнеры бизнес-субъекта.

Разработка ЛБПСП должна начинаться с диагностики потенциала соответствующей бизнес-единицы. В процессе диагностики оценивается его состояние и рассматриваются возможности его улучшения на основе кооперации, концентрации и углубления разделения труда.

Основным разделом локального бизнес-плана должно быть обоснование мероприятий по кооперации элементов его потенциала.

Анализ кооперационных возможностей и потребностей сетевого партнераучастника предпринимательской сети охватывает все стадии его производственно-хозяйственной деятельности. Он включает следующие процедуры:

1. Установление перечня выполняемых основных видов работ, последовательно, в каждом подразделении

2. По каждому виду работ оценивается степень загрузки ведущего оборудования, т.е. оценивая степень использования производственной мощности соответствующего участка (рабочего места).

3. Оценивается качество выполняемых видов работ (на его соответствие ТУ).

4. Оценивается себестоимость выполненных видов работ.

5. Принимается решение о кооперационных возможностях и потребностях каждого вида работ.

Кооперационные возможности оцениваются резервами производственной мощности соответствующего вида работ.

Кооперационные потребности оцениваются: нехваткой производственной мощности соответствующего вида работ; неприемлемостью существующих производственных мощностей по качественным и экономическим показателям.

Анализ технических кооперационных возможностей и потребностей бизнесединицы проводится при разработке проектного варианта. Таким образом, проектный вариант локального бизнес-плана должен включать:

1. Техническое задание, содержание, характеристику предпосылок к вхождению в предпринимательскую сеть.

2. Ведомость технических кооперационных возможностей и потребностей бизнес-субъекта.

3. Ведомость ресурсных потребностей-возможностей бизнес-субъекта.

4. Ведомость кооперационных потребностей возможностей по удовлетворению организационных и пр. потребностей бизнес-единицы.

Исходными данными для разработки комплексного бизнес-плана предпринимательской сети являются проектные варианты (стадии) ЛБПСП.

В проектном варианте КБППС дается сводная ведомость коопераџионных возможностей и потребностей сетевых партнеров. На ее основе делается направление перебор варианта кооперачии и даются конкретные мероприятия по кооперации участников предпринимательской сети.

При их обосновании надо учитывать следующие требования:

1. Социально-психологической приемленности данного варианта кооперации по личностным качествам руководства конкретных бизнес-партнеров. 
2. Концентрации видов кооперационных работ на минимальном количестве бизнес-субъектов (для лучшей управляемости интеграции процессов).

3. Максимального экономического эффекта данного варианта кооперации (с учетом себестоимости работ, ценовой политики, транспортных расходов).

Проектный вариант включает в себя матрииу кооперационных возможностей потребностей всех сетевых партнеров и ранжировании, перечень рекомендуемых кооперационных мероприятий.

Предлагаемые в проектном варианте КБППС мероприятия (кооперационные схемы) передаются для рассмотрения, корректировки и согласования каждому сетевому партнеру (бизнес-единице). На этой основе они составляют свои рабочие варианты ЛБПСП, которые должны включать: подробную ведомость принятых кооперационных мероприятий; их техническую и организационную характеристику; расчет экономической эффективности.

Рабочий вариант КБППС включает:

- общую характеристику технико-экономических параметров участников;

- перечень кооперационных мероприятий;

- матрицу (объемно-календарный план) взаимных кооперационных поставок.

- схему координации взаимодействия (контроллинга) всех участников предпринимательской сети;

- расчет общей эффективности предпринимательской сети.

Локальные и комплексные бизнес-планы должны быть согласованы по срокам. Продолжительность планового периода варьируется в зависимости от конфигурации предпринимательской сети.

Последовательность разработки программы формирования предпринимательской сети представленной на рис.5.3.

Структура программы формирования предпринимательской сети представлена в табл.5.2.

Основой эффекта от создания предпринимательских сетей в строительстве являются:

Формирование единого информационного пространства, которое вырабатывается через взаимодействие отдельных бизнес-субъектов и становится движущей силой их деловой активности. Оно предопределяет: генерацию и обмен новой информацией; создать для единения финансового правового пространства.

Создание единого технологического и производственно-строительного пространства, позволяющего более эффективно загрузить производственные мощности и более рационально использовать основные фонды отдельных сетевых партнеров.

Совершенствование строительных процессов за счет получения доступа к прогрессивным технологиям, сырью, материалам, изделиям, конструкциям, другим элементам ресурсного потенциала партнеров.

Получение, уточнение Т3 на проектирование

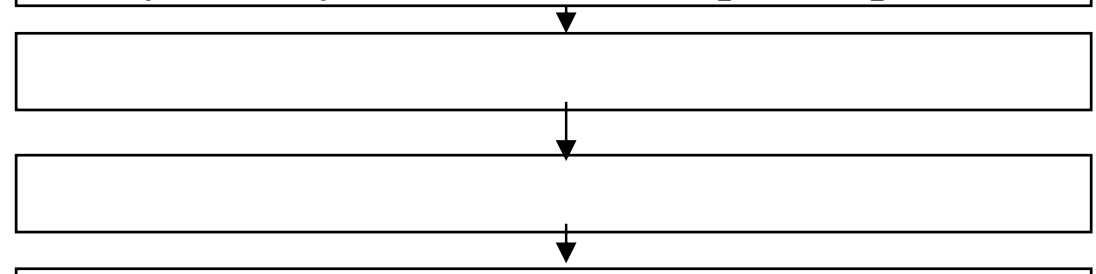


Разработка проектного варианта ЛБПСП - (1-го)

Разработка проектного варианта ЛБПСП - (2-го)

Разработка проектного варианта ЛБПСП - (n-го)

Составление проектного варианта КБППС

Составление рабочего варианта ЛБПСП - (1-го)

Составление рабочего варианта ЛБПСП - (2-го)

Составление рабочего варианта ЛБПСП - (n-го)

Составление проектного варианта КБППС

Рисунок .5.3 -. Последовательность разработки программы формирования предпринимательской сети

Таблица 5.2 -Структура программы формирования предпринимательской сети

\begin{tabular}{|c|c|c|c|}
\hline & Элементы (разделы) & Основное содержание & Назначение \\
\hline 1. & $\begin{array}{l}\text { Проектный вариант } \\
\text { ЛБПСП (n-ой бизнес- } \\
\text { единицы) }\end{array}$ & $\begin{array}{l}\text { Диагностика элементов по- } \\
\text { тенциала бизнес-единицы }\end{array}$ & $\begin{array}{l}\text { Определение интеграционных } \\
\text { потребностей - возможностей } \\
\text { бизнес-единицы }\end{array}$ \\
\hline 2. & $\begin{array}{l}\text { Проектный вариант } \\
\text { КБППС }\end{array}$ & $\begin{array}{l}\text { Составление матрицы ин- } \\
\text { теграционных возможно- } \\
\text { стей - потребностей, ана- } \\
\text { лиз их стоимости и коопе- } \\
\text { рационных вариантов }\end{array}$ & $\begin{array}{l}\text { Составление вариантов коопе- } \\
\text { рационного взаимодействия } \\
\text { сетевых партнеров }\end{array}$ \\
\hline 3. & $\begin{array}{l}\text { Рабочий вариант } \\
\text { ЛБПСП(n-ой бизнес- } \\
\text { единицы) }\end{array}$ & $\begin{array}{l}\text { Анализ приемлемости } \\
\text { предложенных вариантов } \\
\text { кооперационного взаимо- } \\
\text { действия }\end{array}$ & $\begin{array}{l}\text { Разработка и уточнение при- } \\
\text { нимаемых кооперационных } \\
\text { мероприятий }\end{array}$ \\
\hline 4. & $\begin{array}{l}\text { Проектный вариант } \\
\text { КБППС }\end{array}$ & $\begin{array}{l}\text { Составление рабочей мат- } \\
\text { рицы кооперационных ме- } \\
\text { роприятий, необходимых } \\
\text { для формирования и функ- } \\
\text { ционирования сети }\end{array}$ & $\begin{array}{l}\text { Оформление программы реа- } \\
\text { лизации мероприятий пред- } \\
\text { принимательской сети и ее } \\
\text { экономическое обоснование }\end{array}$ \\
\hline
\end{tabular}

Формирование общей коммерческой политики: кооперации в области приобретения ресурсов; реализации строительной продукции; реализации строительной продукции; получение доступа к реализации крупных, перспективных инновационных проектов.

Повышение профессионального уровня и мотивированности персонала: квалификации руководства; квалификации работников; эффективного стимулирования труда. 
Экономический эффект от создания предпринимательской сети обусловлен прежде всего следующими фракторами:

- производственной кооперацией, позволяющей эффективно использовать (загрузить) прогрессивную материально-техническую базу сетевых партнеров и освобождаться от устаревшей или не полностью используемой техники;

- снижением затрат на разработку и модернизацию строительной техники, технологии, новых строительных материалов, деталей, конструкций и т.п. путем передачи этих работ сетевым партнерам, специализирующихся на конкретных видах деятельности;

- повышением эффективности ресурсного обеспечения на основе концентрации этих работ и установления долгосрочных партнерских связей (в первую очередь, обеспечение природным сырьем, техногенными ресурсами, материалами;

- снижение трансакционных издержек, связанных с несоблюдением сроков поставок сырья, с несанкционированным изменением его качественных показателей и т.д.;

- повышением эффективности выполнения отдельных управленческих функций за счет разделения труда, специализации, привлечении специализированных организаций, использование опыта партнеров;

- повышением эффективности деятельности в области реализации ${ }^{1}$ строительной продукции за счет ее концентрации и разделения труда;

- повышением надежности выполнения снабженческих и реализационных функций за счет подбора надежных, долгосрочных сетевых партнеров и их регламентации во времени и пространстве.

Вышесказанное определяет необходимость выявления факторов, создающих предпосылки для повышения эффективности производственно-хозяйственной деятельности бизнес-единицы и комплексного анализа ожидаемого экономического эффекта ${ }^{2}$.

Эффект от вхождения бизнес-единицы в предпринимательскую сеть, т.е. превращение ее в сетевого партнера характеризуется суммой эффектов от кооперации основных элементов ее потенциала. По сути дела он является экономическим эффектом локального бизнес-плана соответствующего сетевого партнера.

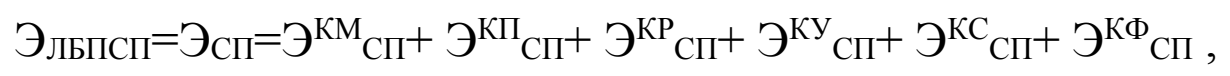

где

$\ni^{\text {КМ }}$ Сп - эффект от кооперации работ по модернизации строительного производства и отдельных процессов, использование ноу-хау партнеров и т.п.;

$\ni^{\text {КП }}$ Сп - эффект от производственной кооперации строительных организаций;

$\ni^{\mathrm{KP}}$ Сп - эффект от кооперации по ресурсному обеспечению;

${ }^{1}$ Под реализацией понимается весь комплекс действий по продвижению различных видов строительной продукции (объектов, работ, услуг) от производителя к потребителю.

2 Заренков В. А. Проблемы развития строительных компаний в условиях российской экономики. - СПб.: Стройиздат, 1999. Организация строительного производства: Учебник для вузов / Под ред. Цая Т. Н., Грабового П. Г. - М.: Ассоциация строит. Вузов, 1999. 
$Э^{\text {Ку }}$ Сп - эффект от кооперации при выполнении управленческих функций;

$\ni^{\text {КС }}$ Сп - эффект от кооперации при выполнении функций в области реализации строительной продукции;

$\ni^{\text {КФ }}$ сп - эффект от кооперации финансовых ресурсов.

Причем степень кооперации каждого элемента потенциала бизнес-единицы может быть от 0 до max.

В процессе расчета экономического эффекта от создания предпринимательской сети необходимо определить:

1. Экономический эффект от одного мероприятия по кооперации одного элемента предпринимательского потенциала.

2. Экономический эффект от улучшения оптимизации одного элемента потенциала (т.е. комплекса мероприятий по одному элементу).

3. Экономический эффект от локального бизнес-плана сетевого партнера, т.е. от улучшения (оптимизации) всего потенциала бизнес-субъекта.

4. Экономический эффект от реализации комплексного бизнес-плана предпринимательской сети.

Необходимо отметить свойства дуализма экономического эффекта от взаимодействия сетевых партнеров. Так, от передачи по кооперации выполнение $\ell$-ой работы должен быть получен экономический эффект:

- строительной организацией - сетевым партнером №1, передающем работы (заказчика);

- строительной организацией - сетевым партнером №2, получающем этап работы (исполнителя).

В общем виде экономический эффект от этого мероприятия будет иметь вид:

$$
\ni^{\mathrm{K \ell}}=\ni^{\ell 3}{ }_{\mathrm{C} 1}+\ni^{\ell \Lambda_{C}}{ }_{\mathrm{C}}
$$

где

$Э^{\ell 3}$ сп1 - экономический эффект заказчика за счет выполнения его работ по кооперации на более качественном и современном оборудовании;

$\ni^{\ell и_{C}}$ - экономический эффект исполнителя за счет оптимальной загрузки производственных мощностей (концентрации и специализации работ).

Формулы для расчета экономического эффекта от вхождения бизнес-единицы в предпринимательскую сеть по основным элементам потенциала предприятия приводится в табл.5.3. 
Таблица 5.3-Формулы для расчета экономического эффекта вхождения в предпринимательскую сеть по основным элементам потенциала предприятия (строительной организации)

\begin{tabular}{|c|c|c|c|}
\hline & \multirow{2}{*}{$\begin{array}{l}\text { Назначение формул } \\
\text { мероприятия }\end{array}$} & \multicolumn{2}{|c|}{ Формулы для расчета экономического эффекта } \\
\hline & & Для сетевого партнера «заказчика» & Для сетевого партнера «испонителя» \\
\hline 1 & 2 & 3 & 4 \\
\hline 1. & $\begin{array}{l}\text { Кооперация работ по мо- } \\
\text { дернизации производства, } \\
\text { использованию ноу-хау }\end{array}$ & 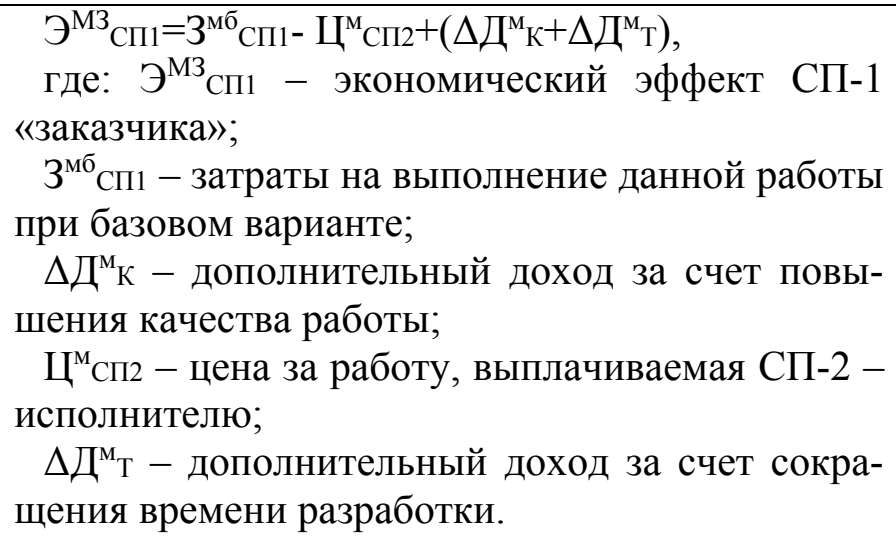 & 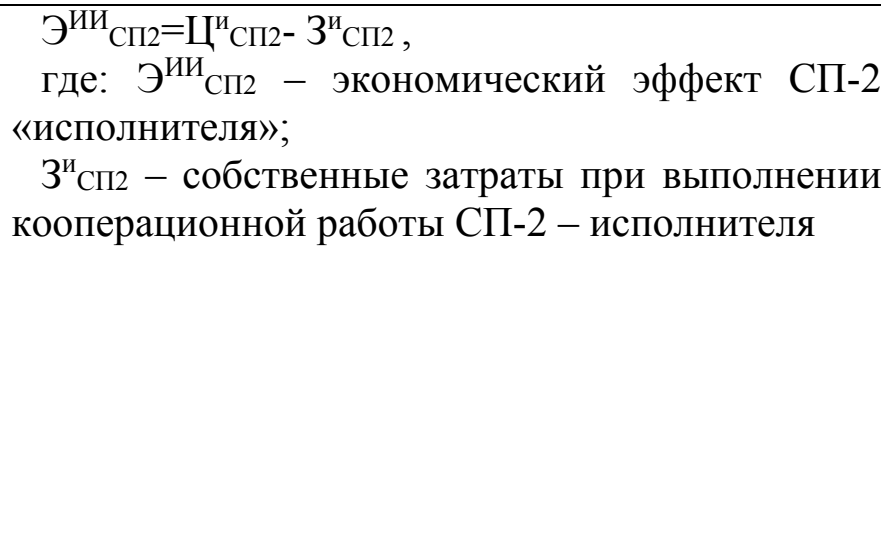 \\
\hline 2. & $\begin{array}{c}\text { Кооперация по выполне- } \\
\text { нию управленческих работ }\end{array}$ & 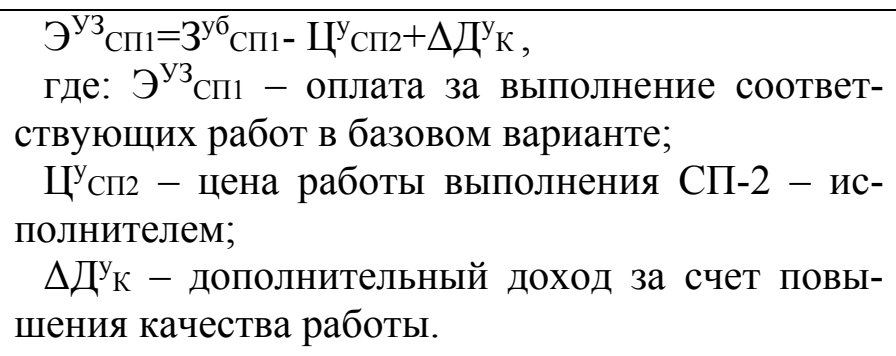 & $\begin{array}{l}\ni^{\mathrm{y}}{ }_{\mathrm{C}}{ }_{2}=Ц^{\mathrm{y}} \text { Сп2- } 3^{\mathrm{u}} \text { сп2, } \\
\text { где: } 3^{\mathrm{u}} \text { Сп2 - затраты исполнителя на выполне- } \\
\text { ние работы по кооперации }\end{array}$ \\
\hline
\end{tabular}




\section{Продолжение таблицы5.3}

\begin{tabular}{|c|c|c|c|}
\hline 1 & 2 & 3 & 4 \\
\hline 3. & $\begin{array}{l}\text { Кооперация по укреплению } \\
\text { производственного элемента } \\
\text { потенциала: использованию } \\
\text { производственных возмож- } \\
\text { ностей, техники основных } \\
\text { фондов и т.д. сетевого парт- } \\
\text { нера }\end{array}$ & 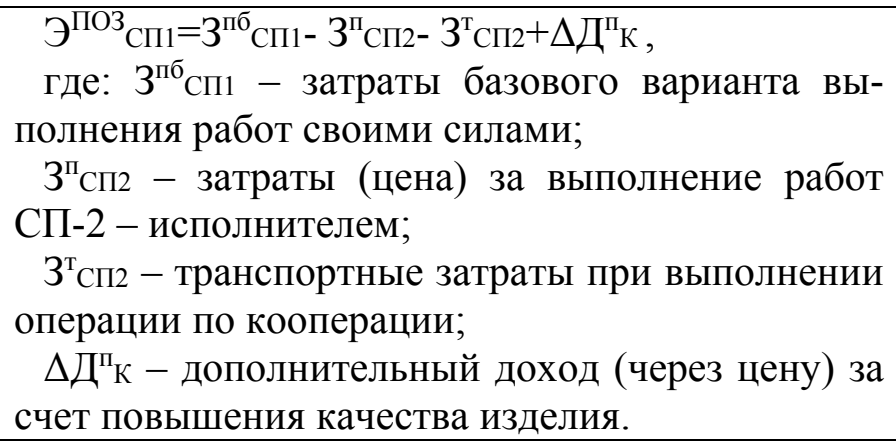 & $\begin{array}{l}\ni^{\Pi о{ }}{ }_{\text {Сп2}}=\Delta 3^{\Pi} \text { ун } \\
\text { где: } \Delta 3^{\Pi} \text { ун }- \text { экономия на сокращении условно- } \\
\text { постоянной части расходов при выполнении } \\
\text { всего объема соответствующих работ; } \\
\Delta Д^{\Pi} \text { сп2 - дополнительный доход за счет вы- } \\
\text { пуска дополнительной продукции (концентра- } \\
\text { ции производства). }\end{array}$ \\
\hline 4. & $\begin{array}{l}\text { Кооперация в ресурсном } \\
\text { обеспечении }\end{array}$ & 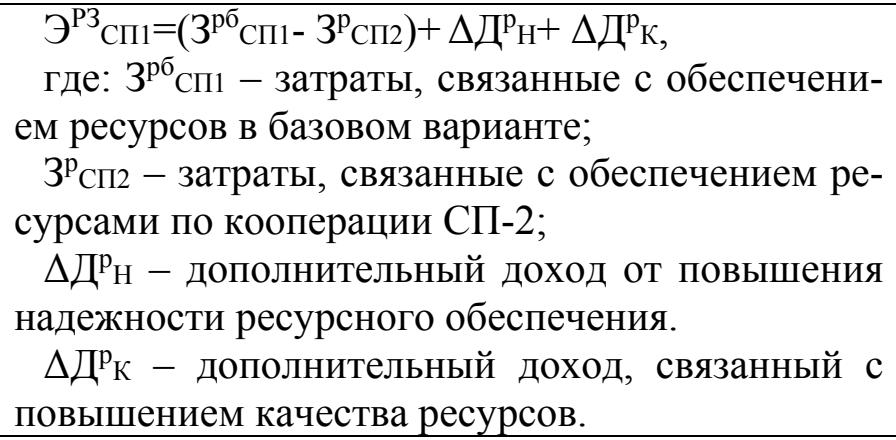 & $\begin{array}{l}Э^{\mathrm{PU}}{ }_{C \Pi 2}=3^{\mathrm{p}} \text { СП2}+Д^{\mathrm{K}} \mathrm{C \Pi 2}, \\
\text { где: } Д^{\mathrm{K}} \mathrm{C \Pi 2}-\text { снижение удельных расходов на } \\
\text { ресурсное обеспечение за счет концентрации } \\
\text { работ. }\end{array}$ \\
\hline 5. & $\begin{array}{l}\text { Кооперация в области pea- } \\
\text { лизации (продвижения) }\end{array}$ & 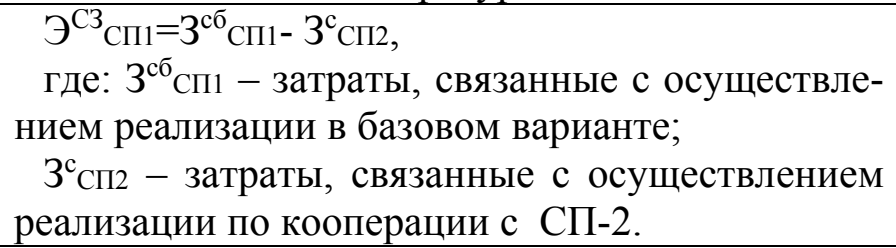 & $\begin{array}{l}Э^{\mathrm{Cn}}{ }_{\text {Сп2 }}=3^{\mathrm{c}} \text { Сп2}+Д^{\mathrm{c}} \text { сп2 } \\
\text { где: } Д^{\mathrm{c}} \text { Сп2 - снижение удельных расходов на } \\
\text { осуществление реализационных операций за } \\
\text { счет концентрации работ. }\end{array}$ \\
\hline
\end{tabular}


На рис.5.4 представлена укрупненная модель составления локального бизнесплана вхождения бизнес-единицы в предпринимательскую сеть, т.е. ее превращение в сетевого партнера.

Предлагается последовательно анализировать экономические параметры предлагаемых мероприятий по кооперации основных элементов потенциала бизнес-единицы. Рассмотрим последовательность необходимых действий и управленческих решений на примере мероприятия по кооперации в области модернизации (обновления) продукции:

1. На основе анализа кооперационных возможностей - потребностей формируется предложение - мероприятие по модернизации изделия.

2. Рассчитываются затраты, связанные с осуществлением данного мероприятия с оплатой работ, выполняемых сетевым партнером.

3. Рассчитывается ожидаемый дополнительный доход от реализации данного мероприятия (возможно: снижение затрат; дополнительный доход за счет высокого качества; дополнительный доход за счет сокращения сроков разработки).

4. Рассчитывается ожидаемый экономический эффект от данного мероприятия.

5. Рассчитывается соблюдение экономических условий, обуславливающих целесообразность реализации данного мероприятия.

6. При соблюдении экономических условий данное мероприятие включается в ЛБПСП, при несоблюдении ставится вопрос об отмене или пересмотре параметров данного мероприятия.

7. Рассмотренные выше процедуры повторяются по всем элементам потенциала рассматриваемого бизнес-субъекта и отобранные экономически обоснованные мероприятия включаются в ЛБПСП.

8. Рассматривается сценарий ожидаемый экономический эффект от реализации данного ЛБПСП.

Экономический эффект от разработки локального бизнес-плана вхождения строительной организации в предпринимательскую сеть имеет вид:

$$
\begin{aligned}
& \text { J L }
\end{aligned}
$$

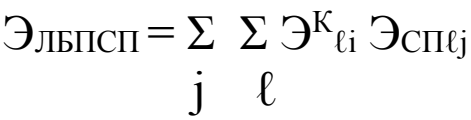

где:

j J - основные элементы потенциала сетевого партнера (строительной организации);

$\ell \ldots L$ - виды работ (мероприятий) по каждому элементу, которые реализуются в данном сетевом партнере (как исполнительного, так и заказного характера). 


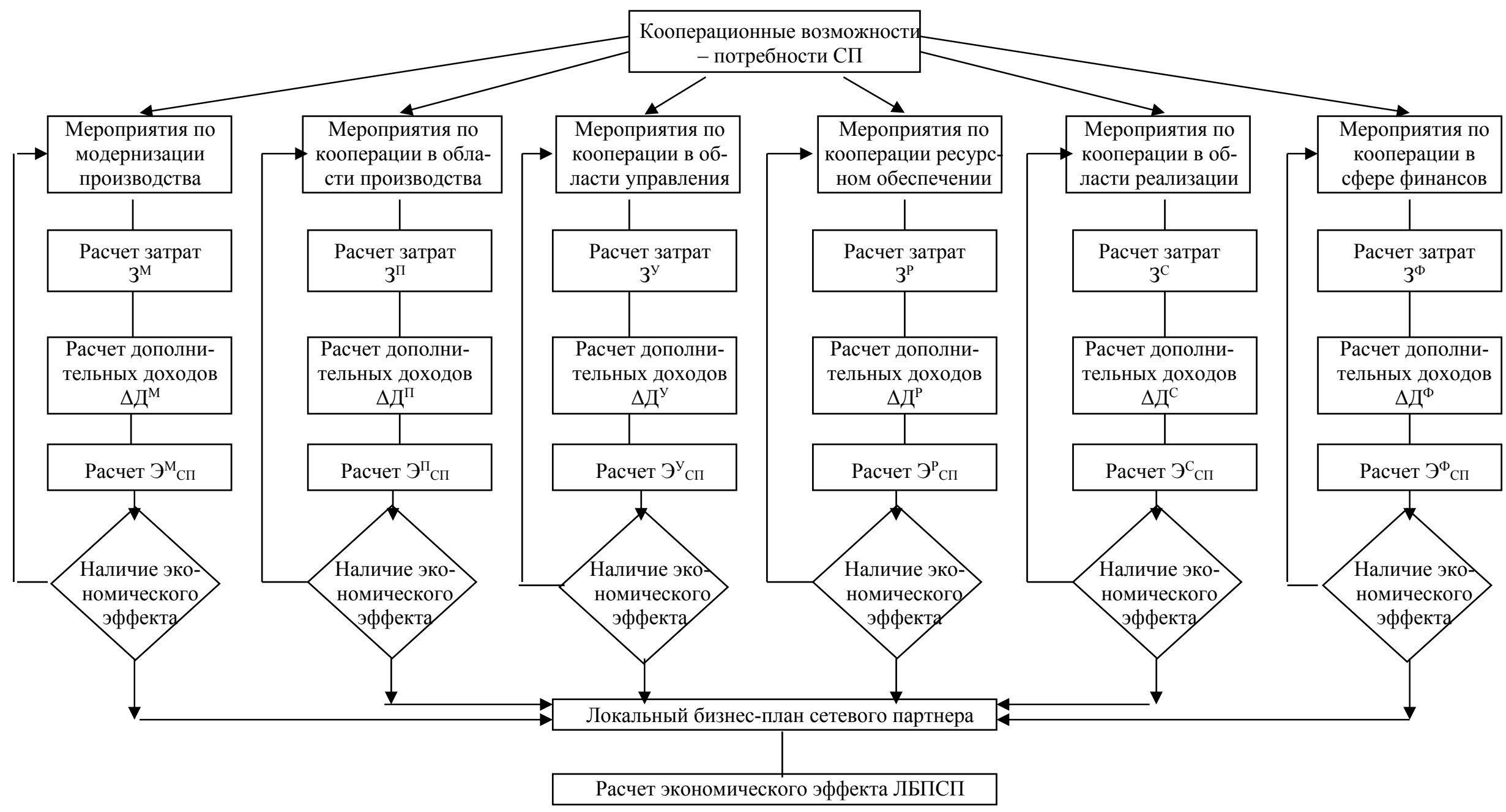

Рисунок 5.4.- Составление локального бизнес-плана сетевого партнера (строительной организации) и обоснование его эффективности 
Выбор лучшего варианта локального бизнес-плана сетевого партнера должен обеспечивать соблюдение условия

$$
\text { Эльпсп } \rightarrow \text { max. }
$$

Экономический эффект от разработки комплексного бизнес-плана предпринимательской сети должен соответствовать условиям:

$$
\begin{aligned}
& \text { I J L } \\
& \text { Эльпсп }=\underset{\mathrm{i}}{\Sigma} \sum_{\mathrm{j}} \mathrm{\ni}^{\mathrm{K}} \mathrm{K}_{\ell \mathrm{i}} \rightarrow \max
\end{aligned}
$$

где:

і ... I - участники данной предпринимательской сети, строительные организации - сетевые партнеры.

\section{3 Региональные сети: Бизнес-центры. Бизнес инкубаторы.}

В последние годы формирование рыночной системы хозяйствования в России сопровождается ростом предпринимательской активности практически во всех сферах экономики. Предпринимательство без сомнения играет определяющую роль в реализации задач переходного периода. Вместе с тем, успешная трансформация административно-командной системы хозяйствования в социально направленную рыночную экономику невозможна без деятельности разных предпринимательских структур, которые обуславливают соответствующие изменения как на макро-, так и на микроэкономическом уровнях.

Вопросам развития предпринимательства придается большое значение в рамках региональной политики поддержки предпринимательства и развития его соответствующей инфраструктуры. В частности, формируются сети региональных и городских бизнес-центров, инновационных центров, бизнес-инкубаторов, технологических парков и т.П., которые могут предоставлять реальную консультативную, информационную, учебную, кадровую и другие виды поддержки субъектам предпринимательской деятельности на начальных этапах их создания.

Бизнес-центр - это, как правило, негосударственная предпринимательская структура, созданная на общественных началах при содействии местной власти и иностранных организаций с целью поддержки развития малого предпринимательства в регионе.

Деятельность бизнес-центра обеспечивается на паритетной и регулярной основе, на принципах социального партнерства, сотрудничества работников органов местного самоуправления, объединений предпринимателей, общественных и профсоюзных организаций работников негосударственного сектора экономики (рис. 5.3). 
Разработке стратегии деятельности бизнес-центра и приоритетных программ его работы по главным направлениям поддержки развития предпринимательства города или района может предшествовать широкая общественная популяризация определенной деятельности с помощью средств массовой информации. Организация открытых тендеров и конкурсов для участия предпринимательских структур (как правило, малых) в разного рода программах, выделение на страницах центральной, областной и городской прессы постоянной рубрики для освещения работы бизнес-центров в сфере развития малого предпринимательства города.

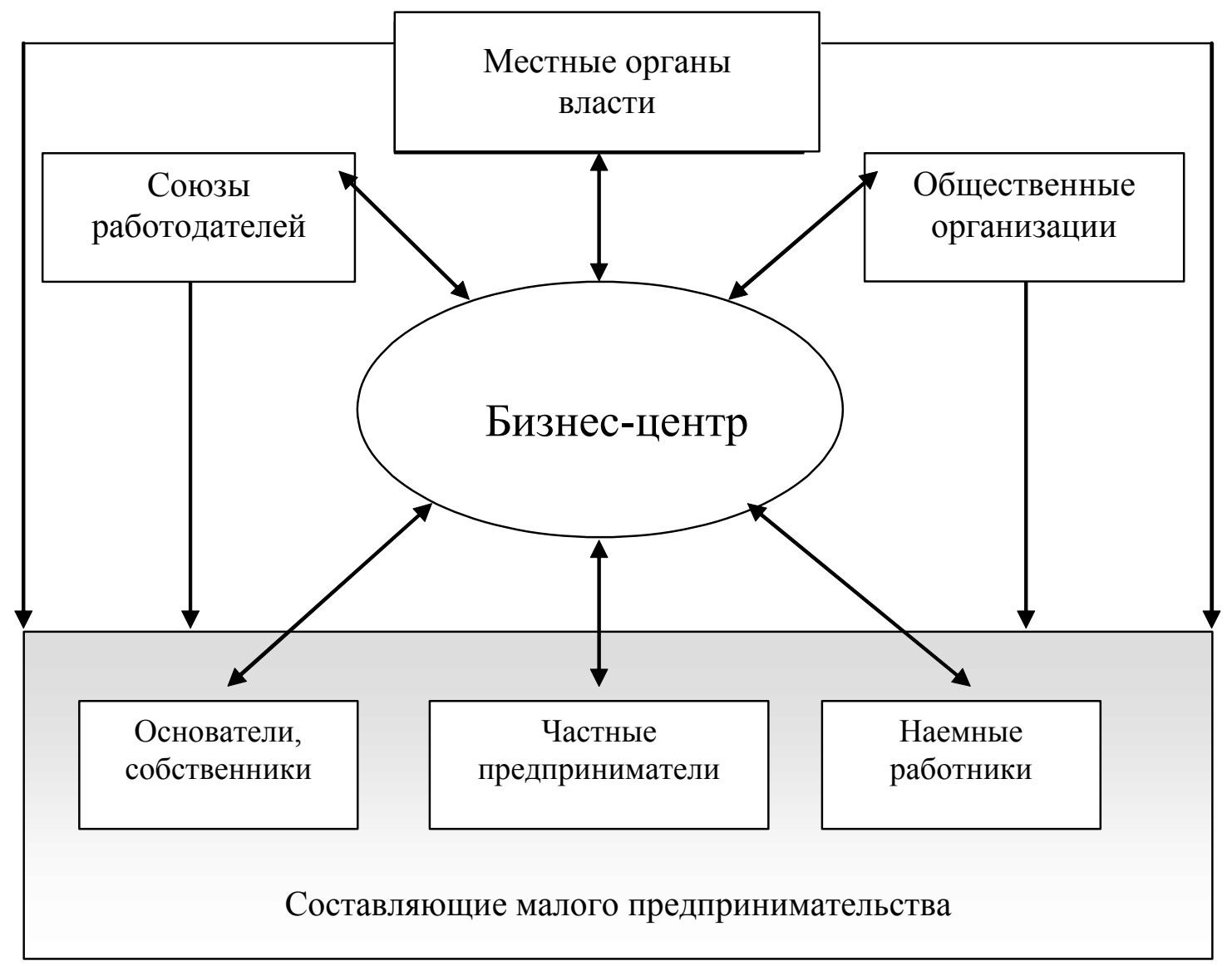

Рис. 5.3. Взаимосвязи бизнес-центра с властью и предпринимательскими структурами

Целесообразно также создание на базе бизнес-центров специализированных клубов, таких, например, как клуб предпринимателей, клуб бухгалтеров и др. с целью проведения семинаров по разным направлениям хозяйственной деятельности, проблемным вопросам отчетности организаций, налогообложения и т.п., в обязательном порядке с приглашением к участию в их работе высококвалифицированных специалистов соответствующей области знаний.

Важно наладить через бизнес-центр получение сводной информации относительно состояния развития малого предпринимательства города или региона, оценивая и сравнивая ее с действующим законодательным полем страны. Поиск механизмов сотрудничества бизнес-центра с политическими партиями, объединениями профсоюзов и общенациональными общественными объединениями может оказывать содействие разработке предложений относительно усовершенствования 
законодательных актов и правительственных документов на уровне государства.

Таким образом, деятельность бизнес-центров, созданных на уровне области, города или района, предусматривает всестороннюю поддержку развития малого и среднего предпринимательства в соответствующих территориальных единицах, реализуя следующие функции по структурно определенным направлениям (рис. 5.4).

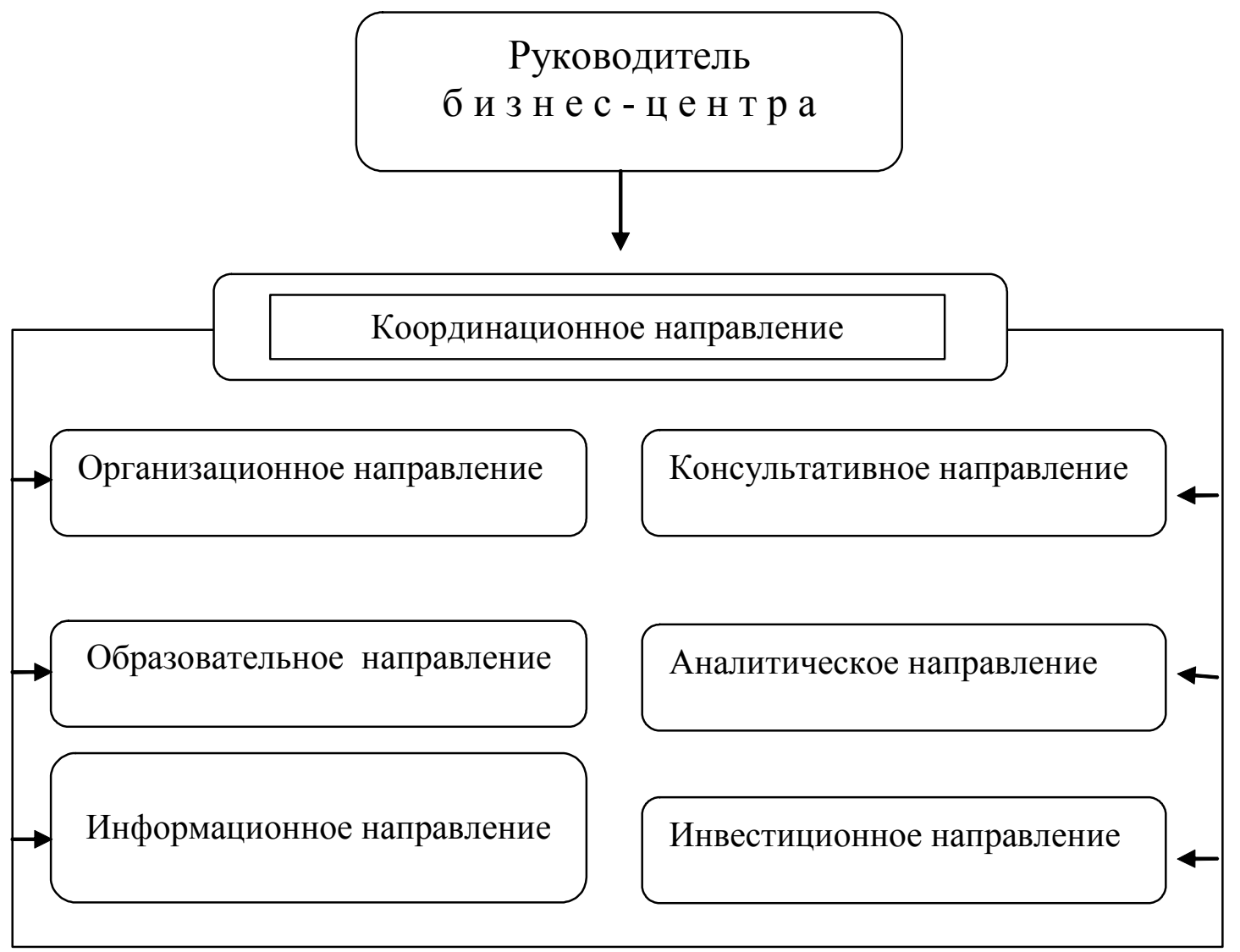

Рис. 5.4 Организационная структура бизнеса-центра

Координационное направление - координация деятельности всех структурных звеньев бизнес-центра:

распределение обязанностей и полномочий между структурными подразделениями центра;

согласование направлений деятельности всех структурных подразделений; оперативное управление решением текущих и стратегических задач

Организационное направление - разработка общих вопросов региональной политики поддержки малого и среднего предпринимательства:

поиск приоритетных направлений развития региона;

разработка концепций и программ развития малого предпринимательства; организация взаимодействия и обратной связи между местной властью и предпринимательскими структурами;

лоббирование законодательства в вопросах малого предпринимательства.

Образовательное направление - проведение активного обучения и переподготовки преимущественно по экономическим специальностям:

предоставление начального экономического образования, как главного базиса, 
необходимого для ведения собственного дела;

проведение тренингов, семинаров в областях маркетинга, менеджмента и финансового анализа.

обучение программам бухгалтерского учета с ориентацией на международные стандарты и использование современной компьютерной техники;

обучение работе с программами бизнес-планирования и стратегического прогнозирования;

проведение тестирования на возможность ведения собственного дела.

Информационное направление - предоставление информации и помощь желающим начать предпринимательскую деятельность:

разработка, распространение и обновление пакетов документов, необходимых для создания предпринимательских структур разных организационных форм;

предоставление юридических консультаций по вопросам регистрации и открытия организаций;

информирование предпринимателей и разработка бизнес-проектов для получения микрокредитов;

предоставление информации по вопросам составления бизнес-планов;

создание банка данных и разное информационное обслуживание.

Консультативное направление - предоставление консультаций и практической помощи действующим и новообразованной организацией:

консультации юриста;

консультации аудитора;

консультации по вопросам бизнес-планирования;

использование компьютерных справочно-поисковых систем;

использование INTERNET (e-mail, телеконференции);

консультации по вопросам получения микрокредитов.

Аналитическое направление - анализ ситуащии на рынке и организаџия маркетинговых исследований:

сбор аналитической информации для размещения на WEB-странице;

изучение рынка деловых услуг и сотрудничество со средствами массовой информации с целью широкого освещения деятельности бизнес-центра и создания положительной общественной мысли относительно развития малого предпринимательства;

сбор и анализ фактов из типичных юридических и бухгалтерских случаев ведения собственного дела, выводов о состоянии законодательства по вопросам предпринимательства, посылка обращений и писем в соответствующие инстанции;

анализ законотворческой деятельности в секторе малого предпринимательства;

сотрудничество с разными общественными советами и комиссиями с целью защиты интересов малого предпринимательства.

Инвестищионное направление - предоставление помощи в поиске инвесторов и получении инвестиций:

создание банка данных потенциальных инвесторов по разным сферам экономики (банков, компаний, фондов);

поиск инвесторов для предприятий малого предпринимательства; 
разработка бизнес-планов, проектов для получения микрокредитов и т.п.

Деятельность бизнес-центров, как правило, сосредоточена на малых предприятиях, управляемых собственниками.

Кроме бизнес-центров в мировой практике получает также развитие концепция бизнес-инкубаторов.

Бизнес-инкубаторы являются перспективной формой поддержки малого предпринимательства. Главное назначение бизнес-инкубаторов состоит в оказании первоначальной помощи малым предприятиям и начинающим предпринимателям. Обычно в бизнес-инкубатор объединяются 10-20 разнопрофильных малых предприятий для реализации предпринимательских проектов. Бизнес-инкубаторы предоставляют предпринимателям услуги, а также обеспечивают своих клиентов консалтинговыми услугами, в первую очередь - информацией об экономической ситуации в регионах и рекомендациями о предпринимательской деятельности, оказывают помощь в подготовке кадров для малых предприятий.

Бизнес-инкубаторы существуют на средства от арендной платы предпринимателей, а также доли от прибыли (или объема продаж) вышедших из «инкубаторов» и успешно функционирующих малых предприятий, на средства промышленных корпораций, учебных заведений и венчурный капитал.

Бизнес-инкубаторы выполняют функции по отбору, приему, размещению и всесторонней поддержке, как правило, новообразованных предпринимательских структур.

Важной задачей при организации бизнес-инкубатора является создание действующей сети из организаций, учреждений и субъектов хозяйствования разных форм собственности, которые могут влиять на экономическое развитие определенного региона. Причем объединение может происходить разными методами: от долевого участия при создании бизнес-инкубатора, как юридического лица, до участия в консультационном совете или сотрудничестве на договорных основах. Объединение разных структур на взаимовыгодных основах может создать благотворительную среду как для развития самого бизнес-инкубатора, так и для экономического развития региона.

Желательными партнерами бизнес-инкубаторов могут быть:

местные органы власти, которые могут играть важную роль при организации его как новой организационной структуры, экономически важной для данного региона, повысить статус бизнес-инкубатора, обеспечить ему необходимую поддержку по отношению к внешней среде, в особенности в решении вопросов, связанных с разными бюрократическими преградами;

объединения предпринимателей региона (союзы, гильдии, ассоциации, фонды), которые пользуются авторитетом в предпринимательских кругах, определенное влияние на формирование экономической политики относительно перспектив развития приоритетных областей региона;

банки и прочие кредитные учреждения, которые могут стать источником привлечения инвестиций в бизнес-инкубатор для новообразованных организаций;

научные учреждения и высшие учебные заведения, которые могут быть поставщиками новых кадров предпринимателей, высококвалифицированных специалистов - менеджеров, финансистов, экономистов, инженеров, разработчиков “ноу-хау”, технических и технологических новаций, а также базовыми учрежде- 
ниями для проведения обучения и переподготовки (тренинга) работников компании, которые могут налаживать деловые контракты, обмениваться опытом, знаниями, находить ниши рынков и т.П..

В зависимости от поставленной цели, особенностей региона и возможностей организаторов могут создаваться разные типы бизнес-инкубаторов, а именно:

1. Поддерживающие новые, инновационные виды предпринимательства.

2. Ориентированные на создания новых организаций, компаний.

3. Объединяющие сеть существующих перспективных организаций разных форм собственности.

4. Комбинированные, специализирующиеся на разных вышеупомянутых формах деятельности.

В зависимости от выбранного типа бизнес-инкубатора и ожидаемых результатов довольно важными вопросами при его создании являются определение критериев отбора и оценка перспективности участников.

Критериями отбора участников бизнес-инкубатора могут быть следующие:

инновационный характер компаний, которые создаются;

потребность в консультировании по вопросам общего менеджмента;

наличие необходимого потенциала развития организации в данном регионе;

перспективность необходимых ресурсов в бизнес-инкубаторе для реализации определенных его целей (например, площади под аренду, оснащение);

взаимная заинтересованность к услугам как со стороны инфраструктуры бизнес-инкубатора, так и отдельных бизнес-структур;

взаимное дополнение и возможность эффекта синергии.

Кроме вновь созданных, в бизнес-инкубатор могут входить на ограниченный срок и уже существующие, успешно функционирующие организации, если они отвечают хотя бы одному из следующих требований:

1. Организация стабильно работает, прибыльная и может обеспечить поступление средств в бизнес-инкубатор за предоставленные ей услуги;

2. Организация владеет опытом, который может быть полезным для других участников бизнес-инкубатора;

3. Организация производит товары (предоставляет услуги), которые могут быть непосредственно использованы участниками данного бизнес-инкубатора.

В зависимости от вида бизнес-инкубатора, местоположения и специализации, его функциональные направления деятельности могут включать разные спектры бизнес-услуг, а именно:

аренда площадей (офисных, производственных, лабораторных, конференцзалов);

техническо-административное обслуживание (почта, интернет, телефон, факс, ксерокс, офис-секретарь и т.п.);

консультационные (по бизнес-планированию, юридическим, налоговым и другим вопросам);

экономические (услуги бухгалтера, финансиста, экономиста, маркетолога, менеджера);

инвестиционные (поиск инвесторов, выдача кредитов, стартовое финансирование новообразованных компаний, создание кредитных союзов);

научно-технические (внедрение новых технологий, «ноу-хау», инноваций); 
учебные (тренинги, курсы переподготовки, обучение по общему менеджменту и другим экономическим специальностям);

презентационные (выставки, конкурсы, конференции);

информационные (создание баз данных, передача новых информационных технологий в бизнесе, интернет-центры и сети);

издательские (издание буклетов, рекламных проспектов, открыток, новейших методических разработок и т.п.);

трудоустройство (поиск работы, базы данных профессий и вакансий, подготовка резюме, подготовка к собеседованию с работодателями и т.п.).

При отборе участников бизнес-инкубаторов важно сделать оценку трех основных составляющих успеха: бизнес-идеи, команды и компании.

Первая - оценка бизнес-идеи. В основе оценки лежит коммерческий (предпринимательский) подход к содержанию (сущности) идеи, который можно определить по следующим критериям:

спрос на товары (услуги), которые предлагаются к производству (величина абсолютного спроса; судьба рынка, который может быть охвачен; степень удовлетворения спроса и т.п.);

наличие необходимых ресурсов (доступность ресурсов; общая стоимость; величина стартового капитала и т.п.);

уровень конкуренции (норма прибыли в данной области, регионе; условия вхождения в рынок; количество конкурентов);

степень интеграции в коньюктуру региона (отдаленность размещения поставщиков и потребителей; географические условия; национальные традиции);

потенциал развития бизнес-идеи (перспективы роста рынков сбыта; продолжительность жизненного цикла товара; ценовая политика);

количество новообразованных рабочих мест (в сравнении с другими проектами; изменения в уровнях оплаты персонала; количество привлеченных квалифицированных специалистов и т.п.).

Вторая - оценка команды. Подход состоит в том, что оценка инициативной группы и любого из инициаторов проекта, которые желают стать участниками бизнес-инкубатора, проводится в соответствии со следующими критериями:

профессиональными качествами специалиста;

личными психологическими характеристиками;

накопленному опыту;

целями и стремлениями личности;

универсальностью и компетентностью команды;

слаженностью в действиях команды.

Третья - оценка компании. Подход относительно оценки организации, которая хочет войти в бизнес-инкубатор реализуется через следующие критерии;

стадия развития компании (до 2-3 лет);

этап жизненного цикла организации (этап роста);

потенциал роста (темпы роста реальные и прогнозные);

достигнутые результаты (судьба рынка; уровень качества продукции; финансовые показатели).

Последний подход особенно важен в случае выбора уже существующей организации, которая может быть включена в число участников бизнес-инкубатора 
для повышения его имиджа и жизнеспособности.

Словосочетание «бизнес-инкубатор» изобрел один американский социолог в конце 50-х годов нашего столетия. Идея его состояла в том, что социолог арендовал за бесценок никому не нужный старый вокзал, разделил его на небольшие комнатушки, провел в них телефоны, нанял высококлассного юриста, консультанта-экономиста и начал сдавать (очень дешево) офисы для начинающих предпринимателей, стимулируя создание ими малых частных предприятий. Результаты превзошли все ожидания. По свидетельствам статистики, из 100 предпринимателей-новичков достигают успехов лишь 12. А в бизнес-инкубаторе социолога, который работал на старом вокзале, почти 30\% предприятий в довольно короткий срок успешно перешло из малого предпринимательства в среднее. Причем значительное количество из них завоевало определенную нишу рынка. Таким образом, бизнес-инкубатор стал питательной средой для начинающих предпринимателей.

Организации, которые вошли в бизнес-инкубатор, были объединены под одной крышей и почти одновременно встречались с типичными для начинающих предпринимателей проблемами. Они начинали активно общаться, проверять свои идеи, учитывать ошибки, обмениваться опытом и значительно быстрее, чем это было бы поодиночке, преодолевать бюрократические преграды и находить пути к успеху. Если им не хватало собственного опыта, они обращались к специалистам: юристам, экономистам, менеджерам бизнес-инкубатора.

Успех первого экспериментального инкубатора привел к тому, что местные власти многих штатов США начали широко финансировать подобные инициативы, предоставлять льготные кредиты под подобные проекты, оказывать спонсорскую помощь для развития бизнес-инкубаторов. Последние рассматривались как школа для предпринимателей, своеобразная стартовая площадка для развития предпринимательства в регионе.

В результате положительного опыта бизнес-инкубации в США данная концепция стала широко развиваться в Европе с учетом определенных национальных особенностей относительно экономических условий формирования соответствующих структур. Причем бизнес-инкубаторы, которые использовали новейшие технологические решения и инновационные идеи стали трансформироваться 8 технологические и инновационные центры, а объединение бизнес-инкубаторов и других инновационных структур с промышленными компаниями, объектами производственной, экологической и социальной инфраструктуры, органами власти привело к созданию научно-технологических парков. Объединение же технопарков стало следующим шагом в развитии инновационных структур и привело к появлению технологических полисов, которые возникают на пересечении деятельности научных и технологических парков.

Ныне накоплен очень большой мировой опыт функционирования упомянутых структур. Рассмотрим особенности создания и деятельности бизнес-инкубаторов в Америке - одной из самых развитых стран мира, как в области науки, так и предпринимательства.

В США функционируют разные типь бизнес-инкубаторов:

Инкубаторы, которые поддерживаются обществом.

Характерным признаком их является то, что помещения и оснащение бизнесинкубатора являются собственностью местной власти, а средства на их становле- 
ние и развитие выделяются из федеральных бюджетов.

Характерный пример: Инкубатор Ист-Енд Менуфекчуринг Сентер, г.Честер, штат Пенсильвания.

Инкубатор в г. Честер, созданный на базе заброшенной трикотажной фабрики, объединяет комплекс из 6 сооружений общей площадью 120 тыс. кв. футов. Специализация - новейшие технологии для легкой промышленности. Отбор организаций, начинающих собственное дело, и их размещение в инкубаторе происходит с учетом потенциальных возможностей освоения новых проектов с целью создания новых рабочих мест. Аренда помещений предоставляется на 3 года. Ведется разработка и строительство помещений научно-промышленного парка, который в будущем должен будет стать местом работы компаний, которые завершат свой срок пребывания в бизнес-инкубаторе. Организациям предоставляются деловые и коммерческие услуги, а также кредиты под низкие проценты. Стоимость проекта создания бизнес-инкубатора составляет 1,3 млн долларов США .

Промышленные инкубаторы. Особенностью этого типа бизнес-инкубаторов есть их учредительство и поддержка большими промышленными организациями вместе с администрациями по экономическому развитию соответствующих штаTOB.

Пример: Полигрефикс Миллз инкубатор, г. Беннингтон, штат Вермонт. Для создания инкубатора Беннингтон Каунти Индастрил Корпорейшн купила здание старой фабрики, получив для ее покупки, восстановления и переоборудования субсидию в размере 900 тыс.долларов, которую предоставила Администрация экономического развития штата Вермонт и заем в размере 250 тыс. долларов от организации Вермонт Индастрил Девелепмент Осорити. Для приведения здания к требованиям бизнес-инкубатора была проведена коренная реконструкция здания и технологическое переоснащение в соответствии со специализацией новых организаций. Суммарные затраты составили 1,1 млн. долларов.

Тем не менее, за довольно короткий срок в инкубатор была принята большая группа организаций, которые довольно быстро реализовали свои проекты, покинули инкубатор и начали самостоятельную коммерческую деятельность.

Организациям, размещенным в бизнесе-инкубаторе, предоставляются льготные кредиты для приобретения и аренды необходимого оснащения. Арендная плата увеличивается по мере пребывания в бизнес-инкубаторе, и это иногда становится одним из условий быстрого выхода из него. Специализация инкубатора технология машинного производства, кухонные комплексы, производство труб и прочее.

Неприбыльные общзественные инкубаторы. Подобного типа бизнесинкубаторы являются, как правило, собственностью общественных неприбыльных организаций, которые соответственно и обеспечивают управление ими.

Характерный пример такого бизнес-инкубатора: Нью Ентерпрейсис фор Вимен Билдинг, г. Гринвилл, штат Миссисипи.

В центре штата компания Миссисипи Екшн фор Комьюнити Едьюкейшн (MЕКЕ) открыла свой бизнес-инкубатор. В его помещениях расположены и получают помощь начинающие организации, собственниками которых есть женщины. МЕКЕ действует как неприбыльная организация и считает, что такой инкубатор является одним из действенных путей развития и поддержки женского предпри- 
нимательства. Для инкубатора МЕКЕ выбрала старое 2-этажное здание, площадью 15 тыс. кв. футов. На его реконструкцию было израсходовано 800 тыс. долларов. Финансируют предпринимательские программы инкубатора штат Миссисипи и фонд Л. Штрауса.

Специализация данного инкубатора - инновации в области торговли, коммерческая и предпринимательская деятельность в сфере услуг. На первом этаже здания размещены 10 магазинов, а на втором - 11 офисов. Каждый магазин занимает площадь от 120 до 175 кв.футов. Данный проект позволил создать в регионе дополнительно около 100 новых рабочих мест.

Деловая помощь предоставляется менеджером инкубатора, который постоянно находится в помещении. Он предоставляет услуги в планировании бизнеса, бухгалтерии, правовых вопросах маркетинга, а также по организации переобучения.

Университетские бизнес-инкубаторы. Их главная особенность - размещение и нахождение в собственности университетов или других учебных заведений или же объединение значительного количества школ, колледжей, институтов и университетов в единый бизнес-инкубатор.

Пример: Едиванст Текнолоджи Дивелепмент Сентер, г. Атланта, штат Джорджия. Открытие бизнес-инкубатора стало результатом усилий штата по созданию условий для научной поддержки и модернизации местной промышленности, развития малого предпринимательства и привлечения в регион высокотехнологических организаций. На третьем году существования в инкубаторе насчитывалось 12 организаций, которые разместились в старом помещении школы площадью 8 тыс.кв.футов. Завершено строительство сооружений под новый инкубатор, площадью 83 тыс.кв.футов, в офисах которого будут размещены органы управления 30-40 новых компаний.

Организациям и их филиалам инкубатор предоставляет производственные площади, оснащение, доступ к компьютерам, разные виды услуг по низким расценкам. Инкубатор разрабатывает промышленные программы для штата Джорджия, ведет переподготовку специалистов для малых предприятий штата.

Студенты технологического института штата Джорджия имеют возможность работать в компаниях инкубатора неполный рабочий день. Все компании при этом пользуются компьютерной сетью института, его библиотекой и техническим оснащением. Консультанты предоставляют целый ряд юридических, экономических и других услуг.

Инкубаторы частных корпоращий. Подобного рода бизнес-инкубаторы создаются частными организациями по личной инициативе и развиваются за счет субсидий частного капитала.

Пример: Контрол Дейта енд текнолоджи Сентер. Контрол Дейта, высокотехничная организация Миннесоты была пионером в создании частных бизнесинкубаторов в Соединенных Штатах. Ее первый бизнес-технологический центр был открыт в 1979 году в г. Сент-Поли, а сегодня корпорация владеет значительным количеством инкубаторов в США и других странах. Контрол Дейта сделала развитие малого предпринимательства частью своей продукции. Лицензии на владение бизнес-инкубаторами были проданы впервые в США штатами Иллинойс и Южная Каролина. Теперь каждый город в этих штатах, открывая бизнес- 
инкубатор, платит Контрол Дейта 50 тыс. долларов.

Кроме платы за лицензию Контрол Дейта установила дополнительную плату от 25 тыс. до 50 тыс. долларов за систему консультаций, которую предоставляют ее специалисты выезжая в город где создается бизнес-инкубатор.

Инкубаторы предоставляют организациям помещения под офис и производственные площади. Опыт Контрол Дейта показал, что условия аренды могут изменяться, а расценки за 1 кв. фут площади могут быть от 1,5 доллара до 16 долларов. Каждый бизнес-инкубатор предоставляет организациям услуги центральной приемной, автоответчика, копировальной техники, секретарские услуги, сбор информации, компьютерное обучение, конференцзал, аудио- и видеотехнику, консультационные услуги и т.п..

За 100 долларов в месяц можно арендовать помещения без офиса, имея лишь почтовый ящик и доступ к услугам инкубатора.

Размеры площадей бизнес-инкубаторов Контрол Дейта колеблются от 40 тыс. до 400 тысяч кв. футов. Общее количество рабочих мест, открытых 554 организациями, составляет близко 4000.

Во многих регионах нашей страны также приобретен положительный практический опыт в решении региональных проблем путем привлечения к процессу бизнес-инкубации малого и среднего частного предпринимательства и предоставления ему необходимой помощи. Дальнейшее развитие в этом направлении возможно при условии проведения тщательного анализа приобретенного опыта, современных условий деятельности малого предпринимательства и выбора стратегических направлений движения на будущее.

Одной из наиболее сложных проблем отечественных бизнес-инкубаторов есть вопрос финансирования. Поскольку процедура получения долгосрочных кредитов на 3-5 лет довольно сложная, типично западный способ их финансирования практически невозможен. Бизнес-инкубаторы большей частью существуют за счет финансирования международных донорских организаций, службами трудоустройства населения при госадминистрациях городов и районов им предоставляются помещения.

Обобщая информацию, полученную от действующих бизнес-инкубаторов, можно отметить следующие источники их финансирования:

a) средства международных фондов, программ грантов и кредитов;

б) средства заинтересованных министерств, местных администраций, союзов и ассоциаций;

в) средства участников инкубаторов;

г) средства спонсоров и инвесторов;

д) средства коммерческих структур и частных лиц, заинтересованных в работе бизнес-инкубаторов.

Серьезной опасностью для развития бизнес-инкубаторов является и то, что они - неприбыльные организации. В лучшем случае они способны возвратить лишь часть израсходованных средств. При этом появляется вероятность, что бизнес-инкубаторы могут создаваться недостаточно квалифицированными и ответственными лицами с корыстной целью. Такая бизнес-инкубация будет способствовать лишь расцвету бюрократии и коррупции, а не серьезному цивилизованному предпринимательству. 
В условиях многоукладной экономики, при отсутствии у подавляющего большинства начинающих предпринимателей теоретических знаний и практического опыта, отсутствии реальной инфраструктуры деловых услуг и беззащитности предпринимателей бизнес-инкубаторы являются очень перспективным организационным нововведением. Успешное развитие экономики, формирование новой структуры производства продукции, выполнения работ и оказания услуг невозможны без создания соответствующей среды, тесного взаимодействия предпринимателей и региональных государственных и общественных организаций. В современных условиях, создание сети бизнес-инкубаторов способно помочь дальнейшему развитию предпринимательской среды, которая стимулирует не только реализацию предпринимательских идей, но и формирование этики делового общения.

\section{4. Инновационные предпринимательские сети: Технологические парки. Технологические полисы.}

Внедрение технологических парков в мировую предпринимательскую среду определяет качественно новый подход к условиям реализации и обеспечения процессов предпринимательской деятельности и созданию благоприятной среды, в которой научные идеи превращаются в уникальную научно-техническую продукцию, осуществляют очередной рывок в области новейших технологий.

Любой город или регион всегда заинтересован в расширении наукоемких производств, в стабильных темпах развития научно-технического потенциала территории, увеличении количества рабочих мест, формировании производственной и социальной инфраструктур, поддержке активной предпринимательской деятельности и постоянном стимулировании развития в регионе науки. Все это может обеспечить в регионе научно-технологический парк.

В зарубежной практике понятие «научно-технологический парк» используется в качестве обобщающего определения мощной инновационной структуры. К этой группе относят исследовательские центры и парки, инкубаторы идей, научные парки, инновационные центры, центры передовых технологий, технологические центры и парки, технологические полисы. Все они составляют основу специализированных инновационных объединений, которые созданы в ведущих индустриальных регионах мира.

В индустриально развитых странах (США, Германии, Франции и др.) широко развита сеть технопарков. Суть ее состоит в том, что предпринимателю нет надобности строить свои производства, их можно взять в аренду и, разместив там необходимое оборудование, выпускать продукцию и получать консультации по внедрению новых технологий на основе разрабатываемых научных идей. Технопарки оказывают содействие учебным и научным организациям в передаче технологий в экономику, в создании новых видов производств и новых рабочих мест.

Основная суть схемы участия в технопарках достаточно проста. Любая частная компания может взять на себя функции управляющей технопарком или получить статус агента по развитию территории, получить разрешение администра- 
ции. Затем необходимо осуществить инженерную подготовку территории, поскольку участки отделенные для технопарков располагаются в районах, где отсутствуют достаточные энергетические мощности и слабые инженерные сети. Следующим шагом станет сооружение объектов под создание промышленных предприятий. Каждая компания, пожелавшая наладить собственное производство, может запросить для себя инженерно подготовленный участок, на котором будет построен завод «под заказчика». Инженерно подготовленную территорию производственная компания может взять в аренду. Также возможен несколько иной вариант. Готовая территория будет разбита на лоты, право аренды на которое затем реализуют на открытых торгах.

Таким образом, технопарки представляют собой особую организационную форму интеграции науки, образования и производства.

Технопарки существуют следующих видов:

научные (фундаментальные исследования);

научно-исследовательские (НИОКР, мелкосерийное производство наукоемких изделий),

научно-технические и технологические (прикладные исследования и разработки, серийное производство наукоемкой продукции с использованием высоких технологий)

комбинированные, содержащие элементы первых трех видов.

Конечно, это деление условно, поскольку на практике зачастую наблюдается комбинация перечисленных выше признаков.

Технопарки могут быть как коммерческими, так и некоммерческими организациями, создаются в любой разрешенной законом организационно-правовой форме и регистрируются в качестве юридического лица

Приведем примеры развитых технологических парков на мировом уровне.

Манчестерский научный парк, Великобритания.

Совладельцы Манчестерского научного парка: городской совет Манчестера, Манчестерский университет, “Джиба-Джейджи”, “Ферранти”, “Фозергил енд Хайвей” и "Гранада Телевижн лимитед". Научный парк имеет также поддержку Манчестерской школы бизнеса, Манчестерского политехнического института, Стендфордского университета.

Манчестерский научный парк начал функционировать в 1984 году. Он расположен рядом с одним из самых крупных в Западной Европе научных и учебных центров и имеет широкие возможности для технологической поддержки. Парк был создан с целью стимулирования предпринимательской деятельности в наукоемких областях промышленности и развития экономики региона путем использования научного потенциала вузов Манчестера и других научных центров. Основу парка составляют компании, созданные учеными и сотрудниками университета авторами нововведений или специалистами, которые ведут разработки на основе сотрудничества с его научными коллективами. Парк должен осуществлять всестороннюю поддержку малым компаниям, предоставлять им необходимые услуги, размещать в специально оборудованных производственных корпусах.

Научный парк имеет 15,5 акров земли, предоставленной на условиях долгосрочной аренды городским советом г. Манчестера.

На первом этапе создания парка Энтерпрайс Хаус предлагает компаниям мно- 
госекционные помещения на основе ренты. Другая часть научного парка развивается как на базе многосекционных сооружений, так и за счет корпусов, строящихся по заказу отдельных компаний.

Энтерпрайс Хаус имеет площадь в 24000 кв. футов. Секции первого этажа имеют площадь около 2000 кв. футов каждая, тем не менее, легко могут быть разделены на две меньшие секции. Верхний этаж может быть приспособлен для обеспечения компаний передвижными секциями площадью от 500 до 2000 кв. футов. К корпусам парка подведены все инженерные сети; помещения, которые предоставляются компаниям, могут быть ими легко переоборудованы с учетом разных потребностей и условий деятельности. Для малых начинающих предприятий возможна дотация на “начальную экипировку”, которая может покрывать до 50\% общей стоимости работ. Секции первого этажа могут использоваться как исследовательские участки, экспериментальные мастерские, стендовые залы.

Для секций в Энтерпрайс Хаус рента составляет 3,5 фунта за кв. фут в год. Плата за услуги составляет от 1,1 фунта за кв. фут (первый этаж) для того, чтобы покрыть расходы на содержание и страхование сооружения. Договор с компанией обычно заключается на период от 1 до 3 лет и может быть продолжен.

Научный парк предоставляет компаниям ряд услуг общего пользования, к ним относятся: прием и контроль за парком автомашин; телекс; внутренние телефоны в каждой секции со связью с Манчестерским университетом, Манчестерской Королевской больницей, зуболечебной школой и региональным компьютерным центром; компьютерная связь каждой секции с университетом; внутренняя почтовая связь с университетом; зал для конференций и анализа предпринимательской деятельности компаний.

Группа менеджеров Манчестерского научного парка, их офис расположены в Энтерпрайс Хаус.

Услуги компании в области менеджмента включают:

сотрудничество с Манчестерским городским советом промышленного развития и Корпорацией экономического развития Большого Манчестера, которые имеют возможность предоставлять разнообразные виды дотаций или финансовой помощи;

обращение с целью поддержки компании парка к фонду “Уокрнорт”, который может обеспечить займами и рисковым капиталом в размере от 10000 до 100000 фунтов стерлингов;

консультации и поддержку Центра городского и регионального промышленного развития;

непосредственный контакт с местным отделом торговли и индустрии, которая может обеспечить региональную выборочную помощь;

непосредственные контакты и сотрудничество с банками и финансовыми компаниями рискованного капитала г. Манчестера.

За новые авангардные проекты компаниям может быть предоставлена региональная выборочная помощь. Это регулируется местным отделом торговли и индустрии городского совета. Кредиты, займы, дотации, в особенности предоставленные на льготных условиях, требуют тщательного обоснования компаниями и рекомендаций экспертного совета.

Технологическое взаимодействие может иметь много форм, включая научные 
и деловые консультации, лицензирование новой технологии, поддержку и экспертизу исследовательских проектов, прокат оснащения, реализацию студенческих работ. С целью содействия компаниям и научным коллективам университета и других вузов формируется автоматизированный банк информации с разработками вузовских ученых, организовано бюро услуг по научным консультациям.

Университет предоставляет компаниям и другие виды услуг, связанных с пользованием библиотекой, компьютерным центром, спортивной базой, аудиовидеоцентром, издательством, клубами. Университетские аудитории для семинаров, конференций, деловых встреч предоставляются компаниям научного парка с существенной скидкой. Это тем более распространяется на театральные и прочие спектакли. В дополнение к структурам университета, которые созданы в интересах взаимодействия с инновационными организациями парка, на его базе действует ряд промышленных секций, созданных крупными организациями г. Манчестера с целью координации исследований и разработок. Среди них: «Коррозион енд Протекшн Сентер Индастриал Сервис», «Вольфсон Индастриал Мейтенанс Юнит», «Микропроцессор Инжиниринг Юнит», «Стендфорд Юнивесити Индастрил Сентер», «Маринетек енд Кемикел Инжиниринг Индастриал Лиазон Сервис».

В Энтерпрайс Хаус расположен центр городского и регионального промышленного развития, который предусматривает информацию и помощь небольшим компаниям в районе г. Манчестера, включая тех, которые находятся в научном парке. Созданный Манчестерским университетом, при поддержке Национального Вестминстерского банка, Центр сформировал банк данных о возможностях научно-технической экспертизы и средств обслуживания, которыми владеет университет. Он также предоставляет компаниям данные анализа рынка, источников финансовой поддержки, редактирования деловых планов. Центр установил прямые связи с другими агентствами, созданными для содействия начинающим и действующим организациям.

Орлеанский технологический парк, Франциия.

Орлеан расположен в центре Франции, в часе езды от Парижа и является финансовой и административной столицей региона. Большое количество национальных и международных компаний расположены именно в Орлеане вследствие развития там динамичных экономических процессов и связей с Университетом и исследовательскими центрами. Орлеан хорошо известен своей научной деятельностью в разнообразных областях, особенно в биотехнологии, энергетике, косметике, фармацевтике и робототехнике.

Орлеанский технологический парк включает также Инновационный центр, который служит связующим звеном между исследовательскими центрами региона и промышленностью для обмена опытом и разработками передовой технологии. Инновационный центр предлагает компаниям помещения лабораторий и исследовательских участков на основе краткосрочной аренды.

Орлеанский технологический парк является базой для создания Европарка специализированной организации, которая предлагает компаниям и вкладчикам пакет документов по структуре, управлению и обслуживанию научных парков, инновационных и технологических центров.

Идея Европарка как организационного, методологического и информационного центра развития территориальных научно-технических и производственных 
систем, научных технологических парков во Франции и странах Европы оказывает существенное влияние на ускорение инновационной деятельности и перестройку производства в развивающихся странах под воздействием технологической революции.

Значимым является определенный опыт создания технопарков в Российской Федерации, где создана всероссийская ассоциация «Технопарк». Основная цель создания ассоциации - содействие в определении и формировании приоритетных направлений инновационной деятельности; реализация научно-технических инновационных проектов и программ в разных сферах науки и техники; решение социально-экономических проблем регионов путем создания малых наукоемких высокотехнологических производств.

Основное направление работы - научно-методологическое и организационное сопровождение научных и технических парков (технопарков), инновационных центров и бизнес-инкубаторов.

Было создано несколько таких технопарков: Томский, Уфимский, Научный парк МГУ, Зеленоградский, Саратовский, Технологический парк МИФИ, Технопарк Электротехнического университета (г. Санкт-Петербург).

Организация «Морозовский проект» поддерживает малое предпринимательство, посредством оказания образовательных, консультационных, информационных и организационно-политических услуг предпринимателям через сеть региональных учебно-деловых центров, сеть которых охватывает более 60 регионов России. Координатор проекта - Академия менеджмента и рынка, в числе учредителей которой ведущие экономические вузы Москвы и Санкт-Петербурга. В рамках указанного проекта разработано свыше 40 образовательных программ, включающих практически весь спектр дисциплин, которые необходимо изучить предпринимателю.

В Санкт-Петербурге разработана программа размещения на городских территориях сети технопарков - своеобразных промышленных зон, в которых сосредоточатся промышленные производства и разнообразные объекты инфраструктуры, обеспечивающие нормальный бизнес-процесс (гостиницы, офисные центры, таможенные терминалы, логистические центры и т. п.), с обязательной охраной и едиными информационными сетями. Организация технопарка подразумевает также обеспечение бизнеса консультантами различного профиля: юристами, специалистами по финансовым вопросам и др.

В числе основных причин, по которым создаются полностью обеспеченные инфраструктурой промышленные территории, - желание крупных западных компаний активно продвигать свою продукцию на российском рынке ${ }^{1}$. Не последняя из причин - наличие относительно дешевой рабочей силы в регионе. Кроме того, выгодное географическое положение Петербурга и Ленинградской области делает удобным как доставку комплектующих, так и налаживание системы сбыта готовой продукции.

В Санкт-Петербурге в стадии юридического оформления находятся схемы

${ }^{1}$ Территории будущих технопарков предложены компаниям Fazer, Elektrolux, Elcoteq и Sanoma, которые намереваются инвестировать в развитие своих производств в регионе не менее \$ 140 млн. Свой «национальный» технопарк хотят иметь китайские компании, есть заявки от других крупных зарубежных производителей. 
строительства «Северо-Западного технопарка» (промзона на ул. Кубинской) и Ново-Парка (на Ржевке), где управляющие компании будут поддерживать работу инженерных сетей и коммуникаций, следить за состоянием дорог, организовывать работу сервисных служб (фабрики-кухни, автосервисной службы, гостиничноделового комплекса, предприятий по пошиву, ремонту, стирке рабочей одежды), охранять технопарк. На территории Северо-Западного технопарка» предполагается разместить 4-5 крупных завода с общим объемом 200 млн. долл. (легкого машиностроения, сварочного производства, электроники), бизнес-центр, центры патентно-лицензионных услуг и технических переводов. Об актуальности создания технопарков свидетельствуют программы развития их в других регионах (например, в Ленинградской области).

Таким образом, основной целью деятельности научно-технологических парков и задачами, которые стоят перед подобного рода структурами является:

содействие финансовой поддержке инновационной деятельности предпринимательских структур, стимулирование разработок и производства принципиально новых высокотехнологических видов продукции, содействие введению в практику новых технологий и изобретений;

содействие проведению государственной политики по формированию рыночных отношений в научно-технической сфере путем поддержки развития инфраструктуры малого инновационного предпринимательства, поощрения конкуренции путем привлечение свободных финансовых ресурсов для их целевого, эффективного использования в рамках реализации программ (проектов) по созданию производства наукоемкой продукции;

участие в разработке, проведении экспертизы и конкурсных отборах местных, региональных и отраслевых программ, которые обеспечивали бы демонополизацию процессов создания и освоения новых технологий, насыщение рынка выработанными на их основе конкурентоспособными товарами;

привлечение на конкурсной основе субъектов малого предпринимательства, отечественных и иностранных инвесторов к реализации государственных научнотехнических программ и проектов;

поддержка освоения и внедрения новых технологий, а также «ноу-хау» с использованием патентов и лицензий.

Эффективность функционирования научно-технологических парков доказана многолетней практикой их деятельности во многих промышленно развитых странах и тех выгод, которые могут получать от их размещения на определенной территории жители, организации, учебные заведения и власть, и которые могут быть использованы в отечественной практике.

Опыт России и других стран показывает, что в местностях, где функционируют технопарки население имеет следующие преимущества:

увеличивается возможность занятости населения с увеличением количества рабочих мест;

повышается обеспечение высококачественными товарами;

вследствие увеличения доходов возрастает уровень жизни;

повышается уровень социальной среды и социального обеспечения;

возрастает образовательный и интеллектуальный уровень населения. 
С появлением технопарков возрастают активы власти:

открываются новые возможности в планировании и координации региональной инновационной политики;

расширяется использование высокотехнологических ресурсов местного значения;

улучшается место территории в межрегиональном и международном разделении труда;

улучшается экономическая обстановка, экономятся средства на охране досуга; сокращаются затраты бюджета, связанные с безработицей;

повышается деловая активность в регионе, возрастают поступления в бюджет; развивается региональная инфраструктура.

С появлением научных и технологических парков открываются новые возможности перед учебными и научными учреждениями:

расширяется и изменяется техническая и организационная база для проведения научных исследований;

активизируется деловая инициатива научных работников, которая открывает дополнительный источник поступлений (доходов) вузов;

расширяются возможности привлечения и воспитания научных кадров, открытия новых научных школ;

воспитывается новое поколение ученых, которые хорошо ориентируются в проблемах предпринимательства;

расширяются научные и деловые связи с другими вузами, научноисследовательским центрами, организациями;

появляются новые базы практики для студентов;

улучшается взаимодействие учебных заведений с властью;

повышается авторитет и престиж вуза.

От создания технопарков, безусловно, выигрывают и предпринимательские структуры региона, в частности:

за счет использования прогрессивных технологий, внедрения “ноу-хау” и т.п.; увеличиваются объемы экспорта продукции;

возрастают деловые связи на международном уровне;

возрастает престиж и конкурентоспособность продукции;

облегчается доступ к научно-технической базе;

открываются возможности использования интеллектуального потенциала ву30в;

появляется возможность общего использования наиболее современного оснащения, которое принадлежит парку.

Все упомянутые и прочие элементы инфраструктуры обеспечивают создание среды, благоприятной для предпринимательской деятельности и оперативного внедрения научных результатов в практику производства, которая является характерной особенностью не только технопарков, но и технополисов.

Одним из новых направлений развития предпринимательских структур, которым будет принадлежать будущее, являются технополисы, - организаичонные формы объединения научных, инновационных, научно-технологических парков $u$ бизнес-инкубаторов на определенной территории с иелью объединения усилий $u$ предоставления мощуного импульса для экономического развития региона. 
Наибольшее распространение они приобрели за два последних десятилетия в Японии. В соответствии с общей стратегией развития этого государства, учитывая возрастающую роль науки и технологии в решении социально-экономических задач, в этой стране определено 18 территориальных центров, в которых происходит формирование региональных научных комплексов (технополисов), ориентированных на приоритетное развитие наукоемкого производства, концентрацию научных сил и укрепление потенциала тех направлений развития науки и техники, которые будут определять уровень производства в XXI веке.

Важными особенностями технополисов есть взаимосвязанное решение задач по модернизации традиционных для данного региона областей промышленности и вывод их на современный уровень, выбор научных направлений, которые могут быть определяющими для данного технополиса, и которые могут обеспечить опережающее развитие производственной инфраструктуры. Но самым важным является создание благоприятных условий для сотрудников, специалистов и жителей той местности, на промышленной базе которой формируется технополис. То есть, главным, является ориентация технополиса на удовлетворение потребностей людей, повышение их жизненного уровня и экономического расцвета региона.

Особое место в программах создания и развития технополисов отводится университетам и проблеме подготовки кадров в соответствии с высокими требованиями, которые выставляет технополис. Ученые и специалисты университетов, других учебных и научных учреждений всегда привлекаются для разработки основных программ развития технополиса, выполняют функции консультантов и экспертов, обучение и переподготовку кадров.

Довольно часто в состав технополисов привлекаются научно промышленные парки, инновационные и технологические центры, исследовательские бизнесинкубаторы и т.п.. Государство оказывает всестороннюю поддержку программам формирования и развития технополисов, в практической реализации которых непосредственное участие берут местные органы власти Японии.

Технополис Нагаока.

В основе создания технополиса Нагаока лежит намерение создать интегрированный комплекс, в котором бы органически были объединены промышленный сектор, научные учреждения и сфера образования, а также социальная инфраструктура, сформированная в их интересах.

В соответствии с этим основным положением концепции разработаны и реализуются три программы:

создание системного промышленного комплекса высокого уровня: развитие робототехники для использования в станкостроительной и металлообрабатывающей промышленности, повышение технологического уровня всех местных организаций;

формирование городского делового комплекса: предоставление широких возможностей для творческой, технически способной молодежи, развитие новых организаций информатики, сервиса, инженерного проектирования.;

развитие на новом уровне агропромышленного комплекса: активизация новых сельскохозяйственных областей и преобразования пивоварения в биотехнологическую область промышленности, использование робототехники в сельском хозяйстве. 
Как центры координации и поддержки программ создания технополиса организованы Фонд технополиса Нагаока и Центр технологического развития региона.

Фонд представляет гарантии банкам, финансовым и другим компаниям, которые финансируют новые компании и проекты, оказывают содействие развитию предпринимательства; осуществляют консультационное обслуживание; проводит обучение технического персонала и менеджеров; предоставляет разнообразную техническую помощь.

Центр технологического развития регионов, призванный объединить усилия правительства, деловых кругов и ученых в реализации концепции создания технополиса, всесторонне оказывать содействие развитию новых для региона высокотехнологических областей промышленности, а также коренной реконструкции и перевода на новые технологии местных традиционных производств.

В структуре технополиса реализуется проект создания “Технодомена - мозгового центра".

В разработке проекта технополиса и его реализации принимают участие Технологический университет Нагаока, Промышленный исследовательский институт префектуры Ниигата, которые рядом с исследованиями и разработками осуществляют функции региональных консультационных центров по проблеме.

Технополис Ниси-Харима.

Создание технополиса Ниси-Харима считается одним из главных проектов программы придания новых черт префектуре Киото в XXI веке. Среди основных положений концепции формирование современного научно-технологического комплекса как регионального центра передовой технологии; создание города, ориентированного на повышение благоустройства и всестороннее развитие общества; реконструкция промышленного потенциала на основе органического объединения наиболее передовых экологически чистых технологий и окружающей среды.

В составе технополиса создается два комплекса: один специализируется на высокотехнологическом машиностроении, второй - на областях, связанных с здравоохранением. В основе первого комплекса лежит лучшее использование возможностей научных коллективов и организаций, которые находятся в районе Ниси-Харима и занятые в сфере машиностроения, химии и электроники, производства новых керамических материалов, в том числе с использованием высокого синтеза. Планируется использование радиационного синхротрона мощностью 6 Гев, который считается самым мощным в мире.

Второй комплекс основан на развитии биотехнологии, медицинской электроники, прецизионной обработки материалов.

В качестве главного координационного органа в структуре формируемого технополиса организован Центр исследований и внедрения наиболее передовых технологий.

Среди программ, разработанных в соответствии с концепцией создания технополиса, особая роль отводится Программе повышения технологического уровня действующих организаций. В ее интересах, в первую очередь, действует Фонд промышленности и технологии технополиса, который финансирует на льготных условиях подготовку и переквалификацию персонала; исследования и разработки, 
направленные на освоение и передачу новых технологий; развитие информационной среды.

Реализуется также программа целевого привлечения к Ниси-Харима организаций, работающих в высокотехнологических областях промышленности и создания для них условий специального субсидирования.

При Технологическом университете Химейцзи организован новый исследовательский институт высоких технологий.

Одним из жизненно важных объектов проекта создания технополиса есть строительство нового города и его функционирование с учетом тех задач, которые он призван решать на качественно новом этапе развития округа. 


\section{ЗАКЛЮЧЕНИЕ}

Развитие теоретико-методологической базы предпринимательства должно вестись, прежде всего, по пути осмысления роли и возможностей предпринимательской деятельности в новых условиях, в видоизмененной внешней среде и на основе разработки научно-методических рекомендаций, обеспечивающих нахождение лучших решений по развитию и функционированию системы предпринимательства, в частности предпринимательские сети. Предложенное в настоящем издании научное обоснование проблемы формирования оптимальных предпринимательских сетей, в максимальной степени соответствует целям и задачам их участников, состоянию и возможностям внешней среды, когда под воздействием внутренних и внешних факторов возникают определенная дестабилизация, несоблюдение экономических принципов рациональной производственнохозяйственной деятельности. В этой ситуации перед бизнес-единицей и ее руководством возникают проблемы. Многие из них могут успешно решаться за счет концентрации производства, углубления специализации и разделения труда.

Многовариантность управленческих решений при формировании предпринимательских сетей в* строительстве (подборе партнеров, обосновании ее конфигурации, определении видов и форм специализации труда и т.д.) делает актуальным выбор наилучших вариантов с учетом параметров строительного бизнеса, состояния и тенденций в изменении конъюнктуры инвестиционностроительного рынка.

Исследование влияния внешней и внутренней среды на функционирование бизнес-единиц позволило авторам проанализировать процессы формирования предпринимательских сетей.

Вхождение бизнес-единицы в предпринимательскую сеть позволяет оптимизировать экономический потенциал всех участников предпринимательской сети, получить синергетический эффект от объединения их ресурсов, переносит конкуренцию межфирменную в конкуренцию объединений (сетей).

Предпринимательскую сеть целесообразно рассматривать как самостоятельный объект управления, имеющий свою цель, свои ресурсы, свои пути достижения поставленной цели. Авторы предложили двухуровневую мо-дель.ее регулирования. Первый уровень, базовый должен реализовываться руководством бизнес-единицы. Оно должно: устанавливать цели своего интеграционного развития; определять свои интеграционные проблемы - возможности; разрабатывать локальные планы развития с учетом своих потребностей и ресурсов с учетом возможностей и ресурсов партнеров.

Второй уровень связан с анализом, координацией, увязкой отдельных локальных стратегических планов сетевых партнеров, с анализом сочетаемости их целей, возможностей и ресурсов.

В работе приводятся принципы, методы и алгоритмы их разработки

В качестве базовых экономико-организационных механизмов, учитывающих специфику и социальную значимость инвестиционно-строительной деятельности рекомендуется использовать локальные бизнес-планы сетевых партнеров и комплексные бизнес-планы предпринимательских сетей.

Основными принципами регулирования, создания и развития предпринимательских сетей являются:

- сочетаемость целей всех участников - сетевых партнеров;

- обеспечение взаимного интереса всех участников в результатах деятельности;

- учет специфики сетевых партнеров и особенностей их интеграции;

- единства стратегических целей и тактических задач;

- проектная проработка и обоснованность решений по ее формированию;

- коллективное участие в принятии решений, касающихся всех сетевых партнеров;

- наличие координационных (ого) центров, обеспечивающих согласованность действий и решений;

- добровольное вхождение в предпринимательскую сеть на взаимовыгодных основах;

- обязательное и своевременное выполнение взятых на себя обязательств, соответствую- 
щих принятым планам;

- обратная связь, непрерывность и своевременная реакция на изменение внутренней и внешней среды.

Процедуры формирования предпринимательской сети должны начинаться с диагностики предпосылок к интеграционному функционированию бизнес-субъекта. Оценивать предпосылки вхождения бизнес-единицы в предпринимательскую сеть целесообразно на основе:

- сбора и анализа данных о социально-психологическом состоянии и предпочтениях руководства (владельцев) бизнес-единицы;

- сбор и анализ данных о социально ориентированных опасностях внешней среды (и ее тенденции);

- сбора и анализа данных, характеризующих основные ТЭП бизнес-единицы, ее экономические результаты (и ее тенденции).

Экономический эффект от создания предпринимательские сети обусловлен:

- производственно-строительной кооперацией, позволяющей эффективно использовать совокупный потенциал сетевых партнеров;

- снижением затрат на модернизацию строительной продукции путем передачи части работ партнерам, специализирующимся в конкретных видах деятельности;

- повышением эффективности процесса обеспечения строительного производства сырьем, материалами, деталями, конструкциями на основе установления долгосрочных партнерских связей;

- повышением эффективности выполнения отдельных управленческих функций за счет разделения труда, специализации, привлечения специализированных организаций строительного профиля;

- повышением эффективности работ в области сбыта и сервисного обслуживания, приобретения необходимых ресурсов;

- повышением надежности сетевых партнеров в инвестиционно-финансовой кооперации.

В работе предлагаются формулы для расчета экономического эффекта:

- от одного мероприятия по кооперации предпринимательского потенциала;

- от улучшения одного элемента потенциала (т.е. комплекса мероприятий по одному элементу);

- от локального бизнес-плана сетевого партнера (строительной организации), т. е. от улучшения (оптимизации) всего потенциала бизнес-субъекта;

- от реализации комплексного бизнес-плана предпринимательской сети (от кооперационного взаимодействия строительных организаций).

Предлагаемые авторами методы и алгоритмы позволяют отобрать наилучшие кооперационные мероприятия бизнес-плана (как локального, так и сетевого) и определить ожидаемый экономический эффект.

Результатом настоящей книги является обоснование механизмов формирования и развития предпринимательских сетей в инвестиционно-строительном комплексе во всем многообразии его составляющих. Предложенный инструментарий позволяет формировать варианты предпринимательских сетей, обеспечивающих наиболее эффективное кооперационное взаимодействие сетевых партнеров. 


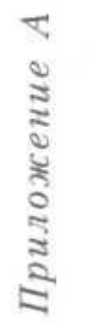

\begin{tabular}{|c|c|c|c|c|c|c|c|c|c|c|c|c|c|c|c|c|c|c|}
\hline 苛 & कึ & ले & $\stackrel{2}{\leftarrow)}$ & $\frac{1}{4}$ & $=$ & ๑ే: & 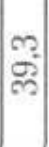 & in & 0 & ले & ஷ্ণ & $\stackrel{-}{\infty}$ & ลิ & 0 & 0 & $\overrightarrow{8}$ & & జ \\
\hline & : & $\begin{array}{l}\stackrel{0}{0} \\
\text { p. }\end{array}$ & $\underset{\forall}{*}$ & 今ి & $\begin{array}{l}0 \\
-7\end{array}$ & $\begin{array}{c}n \\
\infty \\
\infty\end{array}$ & 우 & ळ. & $=$ & $\stackrel{\infty}{\infty}$ & $\frac{m}{2}$ & 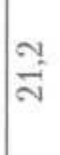 & $\begin{array}{l}\infty \\
\infty\end{array}$ & $\begin{array}{l}\infty \\
15 \mid\end{array}$ & & $\vec{m}$ & & $\frac{12}{1}$ \\
\hline 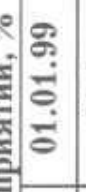 & ले & $\begin{array}{l}r \\
\infty \\
\infty\end{array}$ & $=$ & $\frac{0}{\stackrel{N}{N}}$ & 吾 & $\begin{array}{l}0 \\
=\end{array}$ & 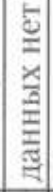 & 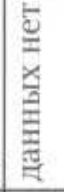 & 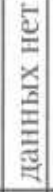 & 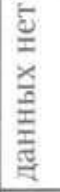 & 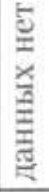 & 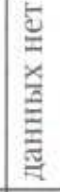 & 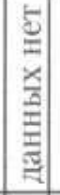 & 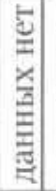 & 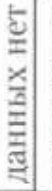 & 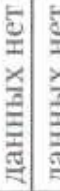 & & 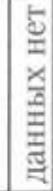 \\
\hline$\frac{\infty}{0}$ & $\frac{\infty}{m}=$ & बे & ल3 & คै & के & $\underset{7}{y}$ & लై & $\stackrel{1}{12}$ & ma & $\stackrel{F}{F}$ & I্ডে & $\frac{0}{N}$ & $=$ & $\infty$ & $\begin{array}{c}\underbrace{2}_{0} \\
-\infty\end{array}$ & 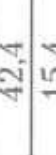 & & $\stackrel{m}{\sim}$ \\
\hline $\mid \begin{array}{l}\tilde{\sigma} \\
\dot{a} \\
\dot{\sigma}\end{array}$ & ले & बे & लै & $\frac{0}{m}$ & 은 & & & $\mid \begin{array}{l}\infty \\
\text { เุ } \\
15\end{array}$ & & ָ2 & กิ & 2 & $=$ & 1 & $\begin{array}{l}\infty \\
c^{\circ}:\end{array}$ & की & & 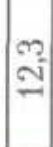 \\
\hline
\end{tabular}

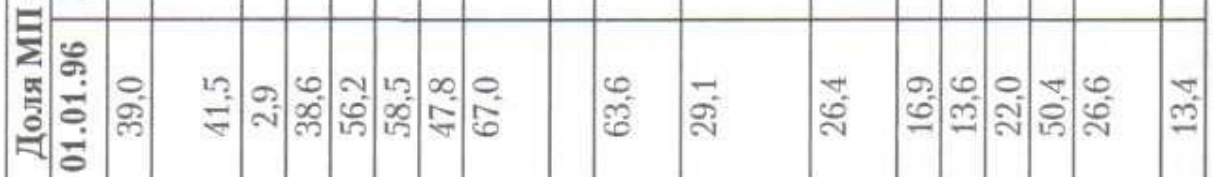

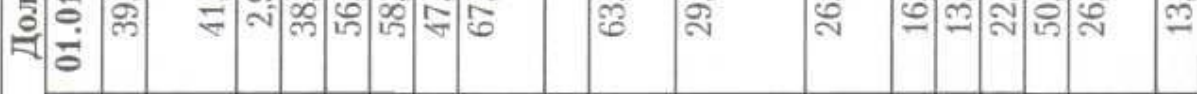

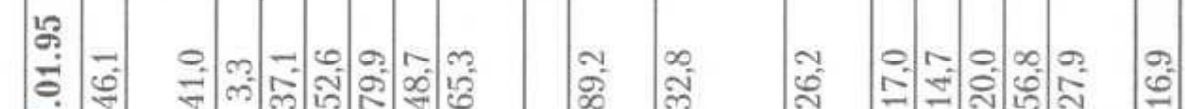

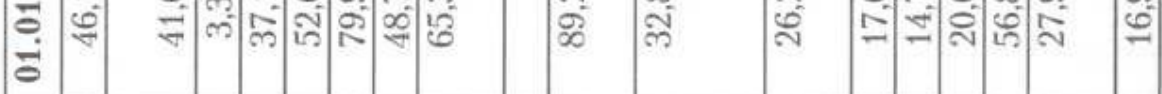

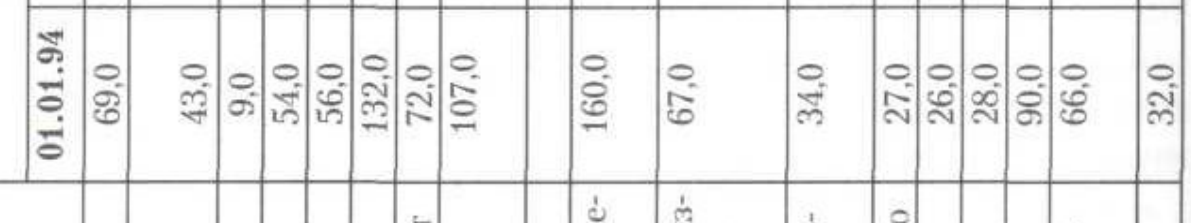

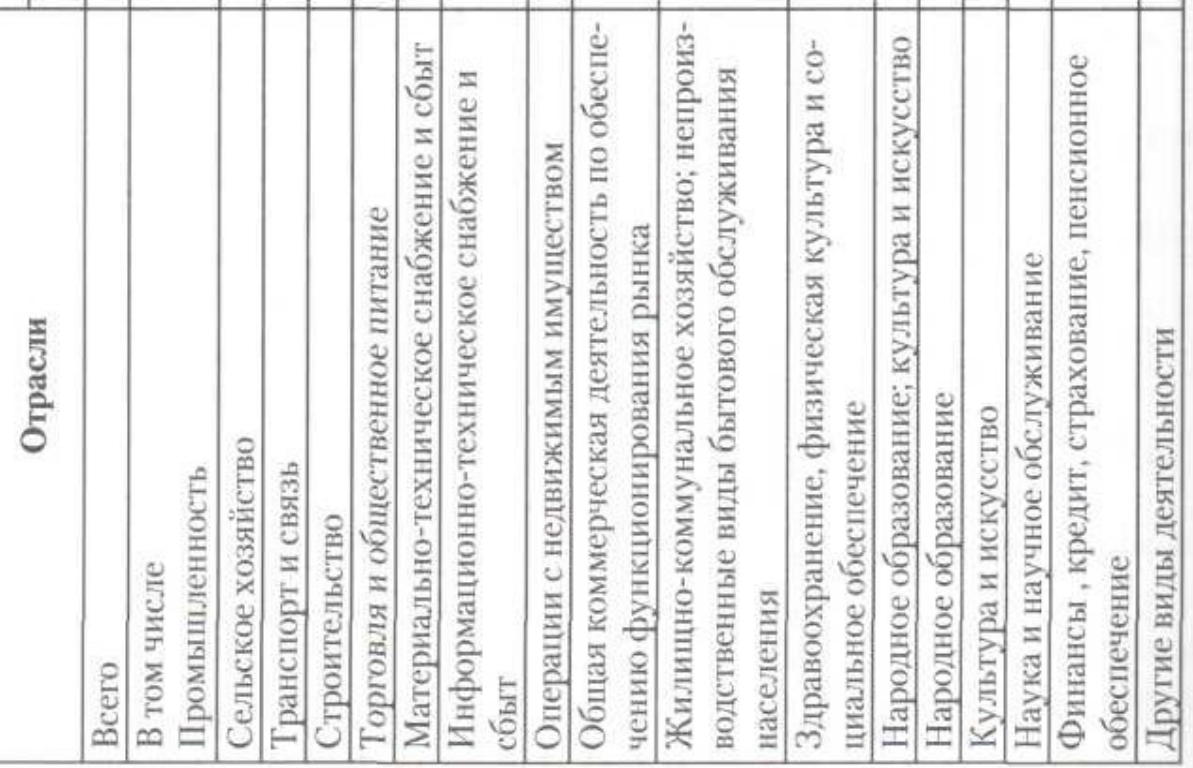




\begin{tabular}{|c|c|c|c|c|c|c|c|c|c|c|c|c|c|}
\hline & $\stackrel{\infty}{=}$ & $\equiv$ & $\overline{\mathrm{i}}$ & 20 & 0 & 0 & ले & $\stackrel{0}{\Xi}$ & กี & 0 & 0 & $\underline{\underline{2}}$ & 0 \\
\hline 产 & $\stackrel{\infty}{=}$ & $\stackrel{2}{=}$ & $\vec{\sim}$ & बे & $\stackrel{\infty}{12}$ & $\overline{0}$ & న్ & $\bar{\Xi}$ & $\vec{m}$ & I & $\stackrel{0}{=}$ & 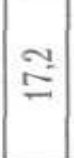 & is \\
\hline 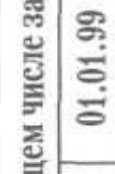 & $\bar{\Xi}$ & $\stackrel{\simeq}{=}$ & $\approx$ & is & กี้ & $=$ & ले & 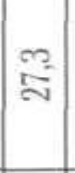 & $\mathrm{m}^{2}$ & ભै & 0 & בิ & $\overline{0}$ \\
\hline 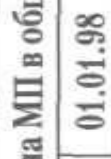 & 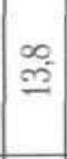 & さี & $\stackrel{\infty}{=}$ & 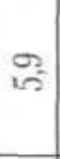 & & & శ్లి & ํํㄹ & 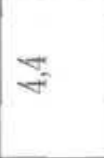 & $\bar{\Delta}$ & $\stackrel{\circ}{i}$ & เి & $\dddot{\infty}$ \\
\hline 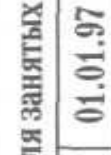 & $\overline{9}$ & $\stackrel{12}{=}$ & $\Xi$ & $\bar{c}=$ & & & $\widehat{\infty}$ & ले & খै & ๙ & $\stackrel{i}{i}$ & $\stackrel{m}{m}$ & $\stackrel{\circ}{=}$ \\
\hline 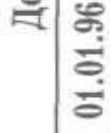 & 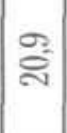 & $\stackrel{\text { g }}{g}$ & $=$ & 12 & & & $\begin{array}{l}\infty \\
8 \\
8\end{array}$ & $=$ & $\mathbb{L}^{2}$ & $\Leftrightarrow$ & ले & $\begin{array}{l}\stackrel{\infty}{\mathfrak{y}} \\
\text { | }\end{array}$ & 0 \\
\hline 迎 & $\overrightarrow{\mathrm{A}}$ & $\stackrel{\vec{\Xi}}{\Xi}$ & $\cong$ & $\ddot{q}$ & & & $\underset{\infty}{\infty}$ & ํํำ & 8 & $\stackrel{\infty}{\text { }^{-}}$ & $\cong$ & 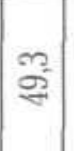 & 0 \\
\hline 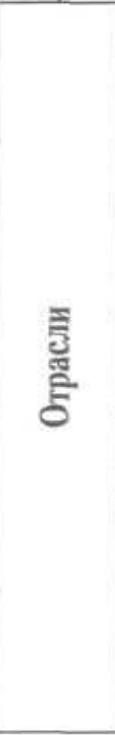 & 总 & 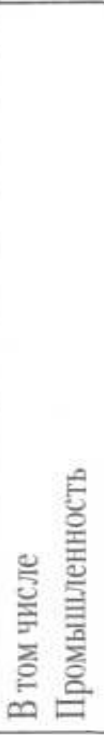 & 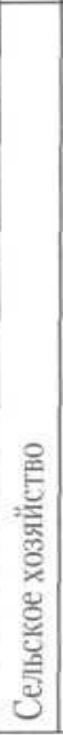 & 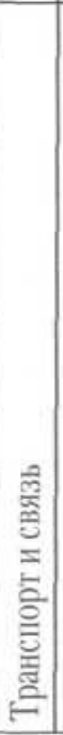 & 昱 & 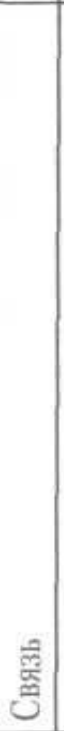 & 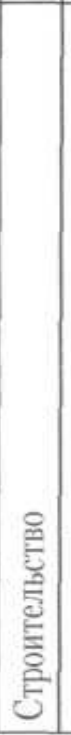 & 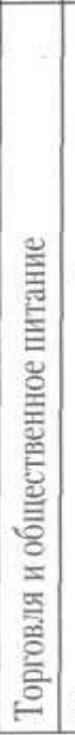 & 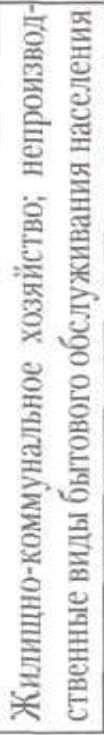 & 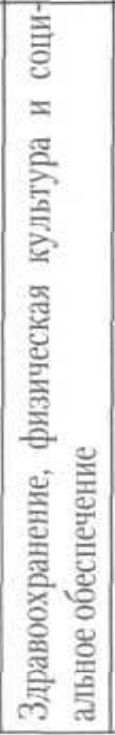 & 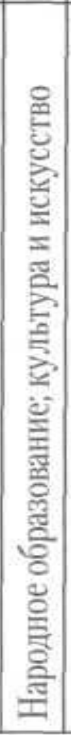 & 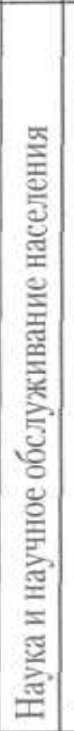 & 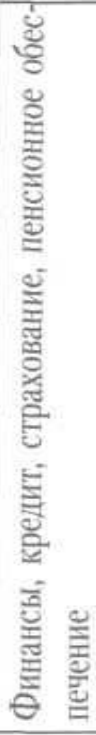 \\
\hline
\end{tabular}


Приложение $B$

Распределение действуюцих строительных организаций по иисленности работников и формам собственности (на 01.01.2001)

\begin{tabular}{|c|c|c|c|c|c|}
\hline & \multirow{2}{*}{$\begin{array}{c}\text { Всего ор- } \\
\text { ганиза- } \\
\text { ций }\end{array}$} & \multicolumn{4}{|c|}{$\begin{array}{c}\text { в том числе по формам } \\
\text { собственности }\end{array}$} \\
\hline & & $\begin{array}{l}\text { государ- } \\
\text { ственное }\end{array}$ & $\begin{array}{l}\text { муници- } \\
\text { пальное }\end{array}$ & частное & $\begin{array}{l}\text { смешан- } \\
\text { ное }\end{array}$ \\
\hline $\begin{array}{l}\text { Все организации, } \\
\text { В том числе: }\end{array}$ & 129308 & 3108 & 1032 & 114814 & 8262 \\
\hline $\begin{array}{c}\text { численность работников: } \\
\text { до } 100 \\
\end{array}$ & 123684 & 2167 & 850 & 111961 & 6700 \\
\hline $101-200$ & 3192 & 588 & 117 & 1641 & 800 \\
\hline свыше 250 & 2432 & 353 & 65 & 1212 & 762 \\
\hline
\end{tabular}




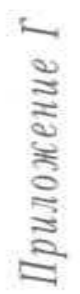

\begin{tabular}{|c|c|c|c|c|c|c|c|c|c|c|}
\hline \multirow{8}{*}{ 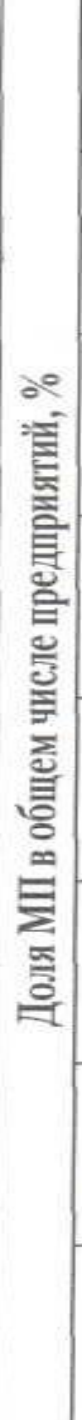 } & $\begin{array}{c}\dot{s} \\
\dot{s} \\
\end{array}$ & $\stackrel{2}{2}$ & & $\stackrel{\Omega}{\stackrel{m}{*}}$ & $\frac{12}{4}$ & 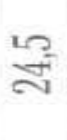 & ב্ت & हैं & న్లి & กิ \\
\hline & | & $\stackrel{5}{s}$ & & हैं & $\underset{f}{2}$ & $\widehat{\mathscr{\Omega}}$ & $\stackrel{B}{\mathbb{Z}}$ & $\stackrel{1}{\infty}$ & के & क्ष \\
\hline & و & हे & & $\bar{\infty}$ & 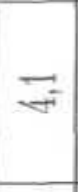 & $\stackrel{\Xi}{\approx}$ & $\underset{q}{q}$ & $\stackrel{0}{=}$ & 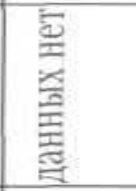 & 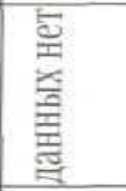 \\
\hline & مُ & $\stackrel{\infty}{-1}$ & & क् & $\stackrel{12}{\infty}$ & ફ̂ & $\bar{\phi}$ & $\stackrel{?}{\mathbb{x}^{\prime}}$ & ఝే & $\vec{n}$ \\
\hline & $\begin{array}{l}\sigma \\
\\
\\
\end{array}$ & 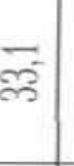 & & gे & ભీ & $\stackrel{0}{\mathrm{~m}}$ & हิ & $\stackrel{2}{2}$ & 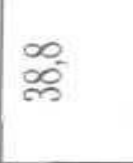 & 绝 \\
\hline & 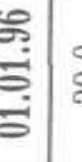 & 峝 & & $\frac{23}{7}$ & a & 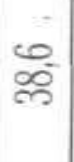 & ถิ & $\begin{array}{l}13 \\
\infty \\
10\end{array}$ & $\stackrel{\infty}{\stackrel{1}{\sigma}}$ & $\frac{0}{6}$ \\
\hline & & $\bar{\sigma}$ & & $\stackrel{0}{\neq}$ & $\dddot{m}$ & $\overline{\text { ले }}$ & กิ่ & 官 & $\underset{\sim}{\infty}$ & $\frac{m}{b}$ \\
\hline & 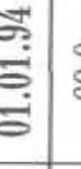 & 항 & & $\underset{\mathscr{z}}{\tilde{F}}$ & 요 & జే & $\mathbb{1 0}^{\circ}$ & ભ & 요 & 으 \\
\hline $\begin{array}{l}\overline{\bar{J}} \\
\text { 芯 } \\
\text { S }\end{array}$ & & 을 & 点 & 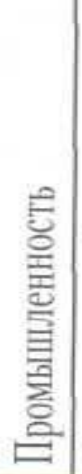 & 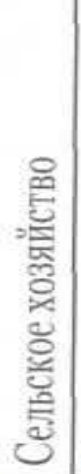 & 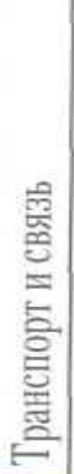 & 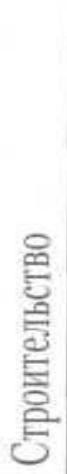 & 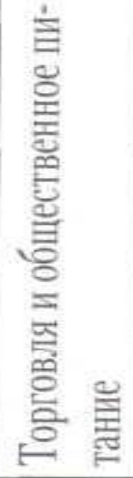 & 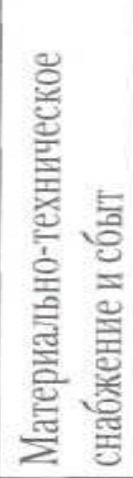 & 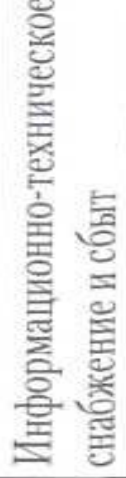 \\
\hline
\end{tabular}




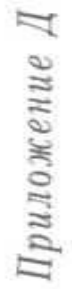

\begin{tabular}{|c|c|c|c|c|c|c|c|c|c|c|c|c|c|c|c|}
\hline & 官 & $\stackrel{\infty}{=}$ & & $\Xi$ & $\bar{\sim}$ & 我 & 0 & 0 & $\frac{\cong}{m}$ & $\stackrel{0}{\sim}$ & กี & 0 & 0 & $\sqrt{3}$ & 0 \\
\hline 츨 & 兽 & $\stackrel{\infty}{=}$ & & $\stackrel{12}{=}$ & $\vec{\sim}$ & $\sigma^{2}$ & $\stackrel{\infty}{\infty}$ & $\sigma^{\prime}$ & กิ & $\approx$ & $\vec{ल}$ & I & $\stackrel{0}{-}$ & $\cong$ & $12=$ \\
\hline 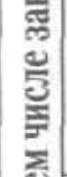 & $\begin{array}{l}\text { gా } \\
\\
\\
\end{array}$ & $\vec{\beth}$ & & $\cong$ & ñ & $\begin{array}{l}0 \\
105\end{array}$ & นิ & $\Rightarrow$ & $\vec{m}$ & $\begin{array}{l}n \\
\Sigma\end{array}$ & ले & $\overrightarrow{n^{\prime}}$ & 0 & ๙ิ & $\overrightarrow{0}$ \\
\hline 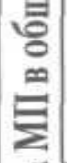 & 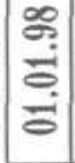 & $\stackrel{\infty}{m}$ & & $\stackrel{\Re}{\beth}$ & $\stackrel{-}{-}$ & sis & & & శ్లి & טิ? & $\rightleftarrows$ & స్ & 요 & है & $\tilde{\infty}^{\prime}$ \\
\hline 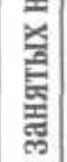 & $\begin{array}{l}\tilde{\sigma} \\
\overline{0} \\
\dot{0}\end{array}$ & $\vec{m}$ & & $\stackrel{13}{=}$ & \pm & $\overrightarrow{15}$ & & & $\widetilde{\infty}$ & $\vec{m}$ & $\underset{+}{*}$ & ๙ & 오 & $\frac{m}{m}$ & $\stackrel{0}{=}$ \\
\hline 을 & $\frac{8}{8}$ & 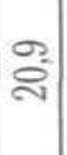 & & $\overbrace{}^{2}$ & $\Rightarrow$ & $\begin{array}{l}12 \\
6\end{array}$ & & & $\begin{array}{l}\infty \\
8 \\
8\end{array}$ & $\Rightarrow$ & हैं & $\stackrel{\circ}{\&}$ & $\ddot{m}$ & $\stackrel{\infty}{\dddot{q}}$ & 0 \\
\hline & Lبْ & $\overrightarrow{\mathcal{N}}$ & & $\stackrel{\Xi}{=}$ & $\dddot{m}$ & $\underset{\sim}{\infty}$ & & & $\mathbb{\infty}^{t}$ & 步 & 8 & $\stackrel{\infty}{\mathfrak{m}^{\prime}}$ & $\cong$ & $\tilde{g}$ & 0 \\
\hline & 氙 & 윯 & 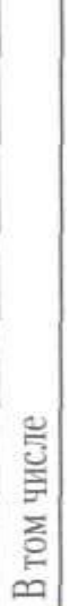 & 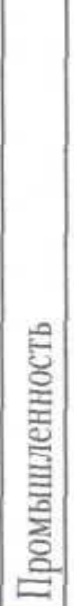 & 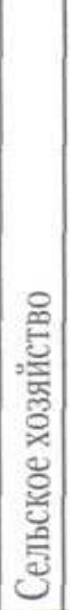 & 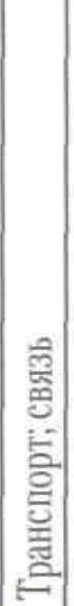 & 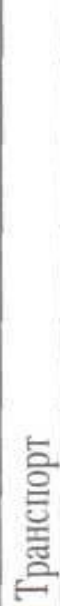 & लํ్ํ & 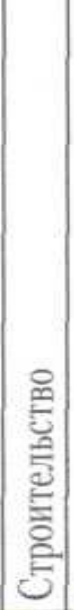 & 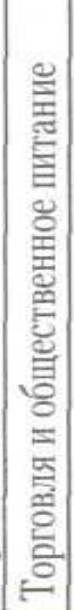 & 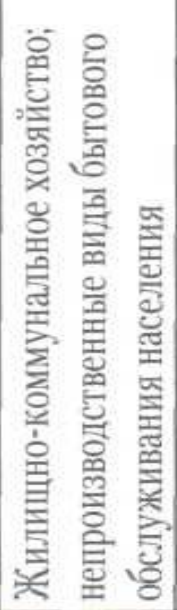 & 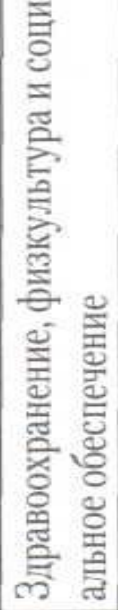 & 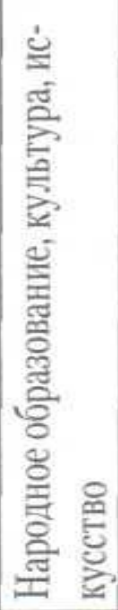 & 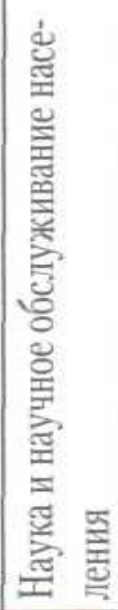 & 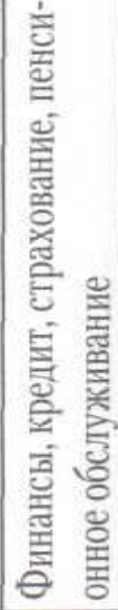 \\
\hline
\end{tabular}




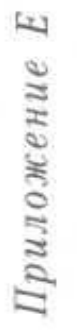

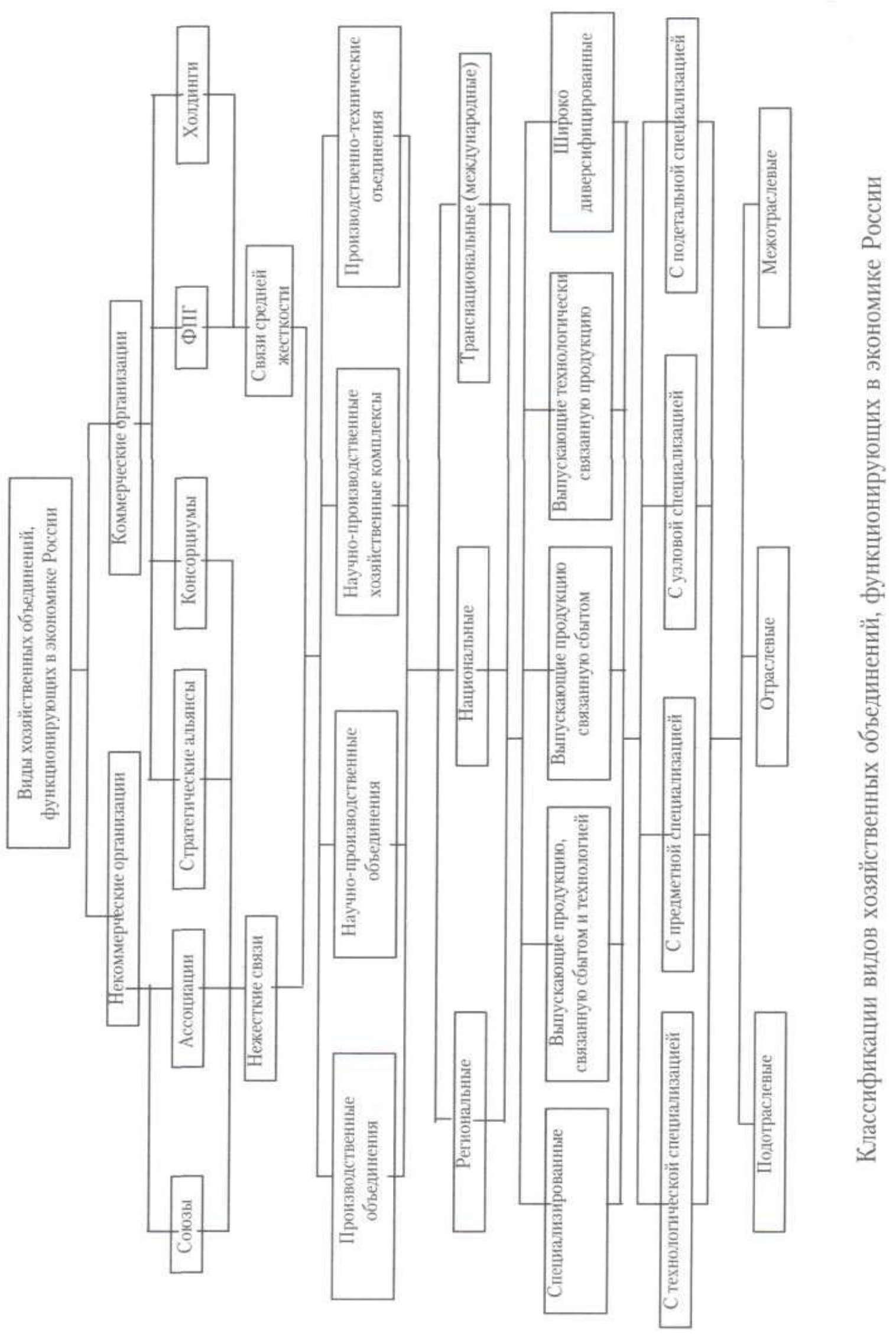


Основные характеристики сетевых организаций

\begin{tabular}{|c|c|c|c|c|}
\hline $\begin{array}{l}\text { Тип } \\
\text { сети }\end{array}$ & $\begin{array}{l}\text { Особенности } \\
\text { организаций }\end{array}$ & $\begin{array}{c}\text { Сферы } \\
\text { применения }\end{array}$ & $\begin{array}{c}\text { Недостатки, } \\
\text { связанные с } \\
\text { расширением } \\
\text { сети }\end{array}$ & $\begin{array}{c}\text { Недостатки, } \\
\text { связанные с мо- } \\
\text { дификацией } \\
\text { структуры }\end{array}$ \\
\hline 1 & 2 & 3 & 4 & 5 \\
\hline $\begin{array}{c}\text { Ста- } \\
\text { бильная }\end{array}$ & $\begin{array}{l}\text { Крупная фирма } \\
\text { (с центром), } \\
\text { создающая ры- } \\
\text { ночно-ориенти- } \\
\text { ованные связи с } \\
\text { ограниченным } \\
\text { потоком ин- } \\
\text { формации вверх } \\
\text { и вниз }\end{array}$ & $\begin{array}{l}\text { Добывающие от- } \\
\text { расли, требующие } \\
\text { крупных капитало- } \\
\text { вложений. Разно- } \\
\text { образная собствен- } \\
\text { ность ограничивает } \\
\text { риск и побуждает к } \\
\text { полному использо- } \\
\text { ванию всех ресур- } \\
\text { сов }\end{array}$ & $\begin{array}{l}\text { Чрезмерное ис- } \\
\text { пользование по- } \\
\text { ставщика или } \\
\text { продавца может } \\
\text { привести к не- } \\
\text { здоровой зави- } \\
\text { симости от цен- } \\
\text { тра фирмы }\end{array}$ & $\begin{array}{l}\text { Большие наде- } \\
\text { жды, возлагае- } \\
\text { мые на коопера- } \\
\text { цию, могут ог- } \\
\text { раничить твор- } \\
\text { чество партне- } \\
\text { ров }\end{array}$ \\
\hline $\begin{array}{l}\text { Внут- } \\
\text { ренняя }\end{array}$ & $\begin{array}{l}\text { Совместное } \\
\text { владение, рас- } \\
\text { пределение ре- } \\
\text { сурсов по цепи } \\
\text { ценностей с ис- } \\
\text { пользованием } \\
\text { рыночных ме- } \\
\text { ханизмов }\end{array}$ & $\begin{array}{l}\text { Добывающие от- } \\
\text { расли, требующие } \\
\text { крупных капитало- } \\
\text { вложений. Рыноч- } \\
\text { ные цены позволя- } \\
\text { ют оценивать внут- } \\
\text { ренние подразделе- } \\
\text { ния }\end{array}$ & $\begin{array}{l}\text { Фирма может } \\
\text { расширить вла- } \\
\text { дение активами } \\
\text { за пределы воз- } \\
\text { можностей внут- } \\
\text { реннего рынка и } \\
\text { механизмов } \\
\text { оценки резуль- } \\
\text { татов деятельно- } \\
\text { сти }\end{array}$ & $\begin{array}{l}\text { Исполнитель- } \\
\text { ные лица ис- } \\
\text { пользуют ко- } \\
\text { манды вместо } \\
\text { влияния и сти- } \\
\text { мулов, чтобы } \\
\text { направлять } \\
\text { внутренние опе- } \\
\text { рации }\end{array}$ \\
\hline $\begin{array}{l}\text { Дина- } \\
\text { мичная }\end{array}$ & $\begin{array}{l}\text { Независимые } \\
\text { фирмы вдоль } \\
\text { ценностной це- } \\
\text { пи формируют } \\
\text { временные сою- } \\
\text { зы из большого } \\
\text { количества по- } \\
\text { тенциальных } \\
\text { партнеров }\end{array}$ & $\begin{array}{l}\text { Отрасли с низким } \\
\text { техническим уров- } \\
\text { нем, с коротким } \\
\text { производственным } \\
\text { циклом и динамич- } \\
\text { но изменяющиеся } \\
\text { высокотехнологич- } \\
\text { ные отрасли (элек- } \\
\text { троника, биотехно- } \\
\text { логия и т.д.) }\end{array}$ & $\begin{array}{l}\text { Экспертиза мо- } \\
\text { жет оказаться } \\
\text { слишком узкой } \\
\text { и выгоды от } \\
\text { ценностной цепи } \\
\text { могут достаться } \\
\text { другой фирме }\end{array}$ & $\begin{array}{l}\text { Значительные } \\
\text { механизмы мо- } \\
\text { гут быть разра- } \\
\text { ботаны, чтобы } \\
\text { предотвратить } \\
\text { сопротивление } \\
\text { партнеров. Ог- } \\
\text { раниченное об- } \\
\text { щение с ниже- } \\
\text { стоящими и } \\
\text { вышестоящими }\end{array}$ \\
\hline
\end{tabular}




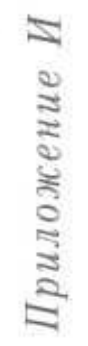

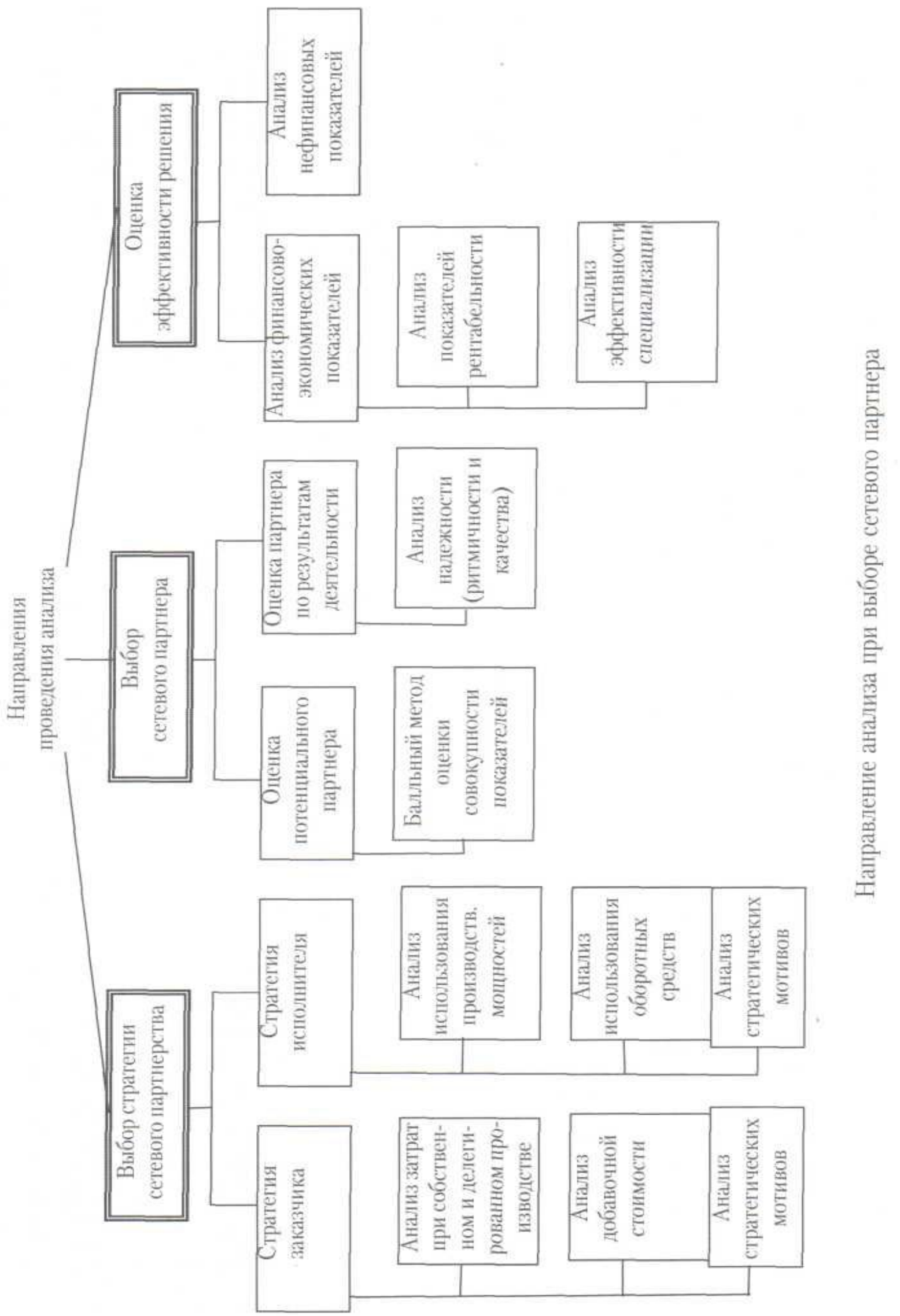




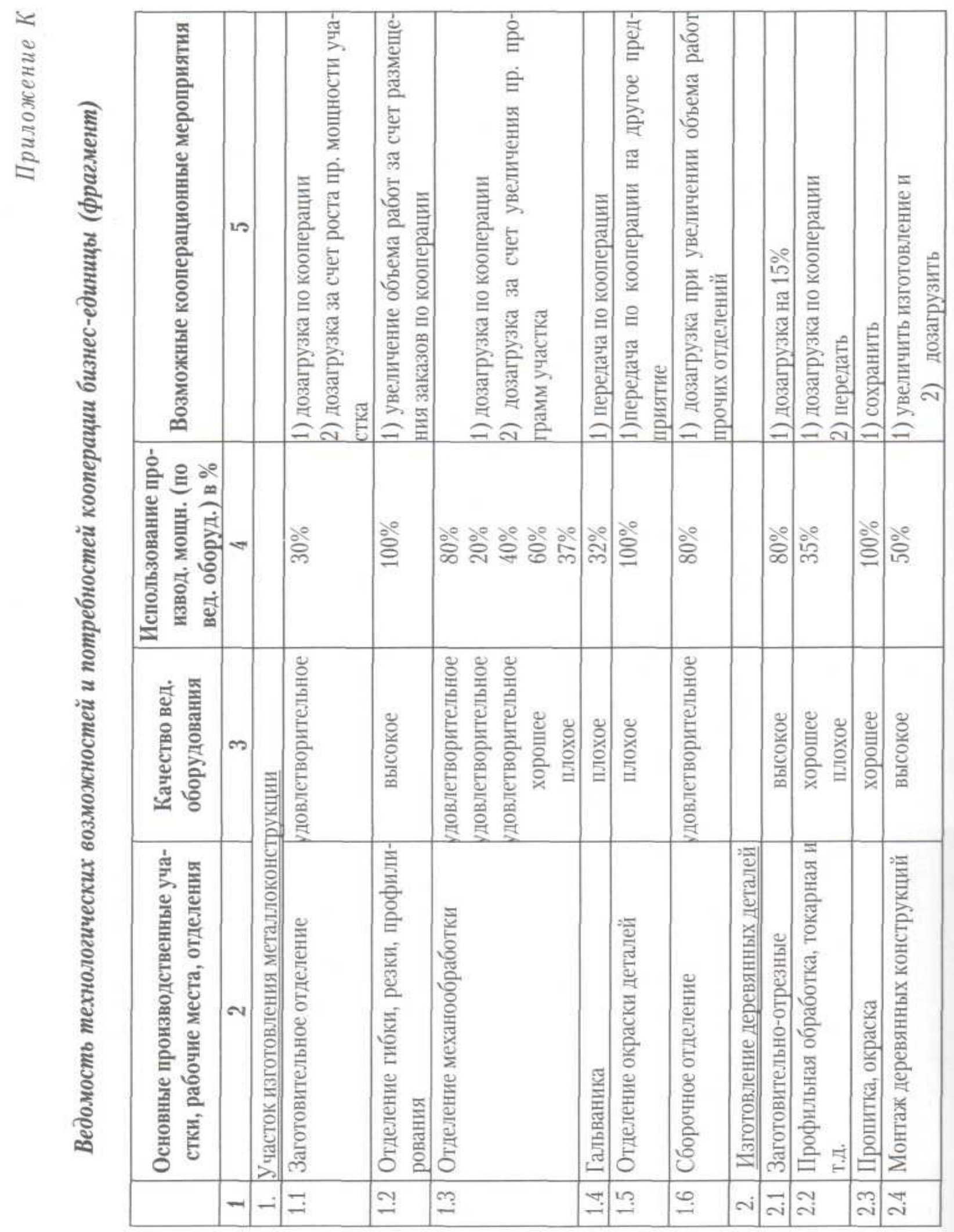




\section{СОДЕРЖАНИЕ}

ВВЕДЕНИЕ

ГЛАВА 1

ЭКОНОМИЧЕСКИЕ ПРИНЦИПЫ И СОДЕРЖАНИЕ ПРЕДПРИНИМАТЕЛЬСТВА

1.1. Роль предпринимательства в российской экономике .

1.2. Генезис основ теорико -методологических основ в предпринимательстве

1.3. Сущность предпринимательства

1.4. Нестабильность, неопределенность и риск в предпринимательской деятельности

\section{ГЛАВА 2}

ПРЕДПРИНИМАТЕЛЬСКАЯ СРЕДА

2.1. Внешняя и внутренняя среда предпринимательства 59

2.2. Ц6ели и задачи предпринимательской деятельности 65

2.3. Культурная среда предпринимательства 70

2.4. Внутрифирменное предпринимательство (интрапринерство) 80

\section{ГЛАВА 3 \\ ФОРМИРОВАНИЕ И РАЗВИТИЕ ПРЕДПРИНИМАТЕЛЬСКИХ СЕТЕЙ}

3.1 Сетевые формы объединения организаций (кластеры, предпринимательские сети)

3.2 Отечественный опыт формирования предпринимательских сетей

3.3 Исследование влияния факторов внешней и внутренней среды сетевых объединений

3.4 Процессы формирования и функционирования предпринимательских сетей

4.2 Особенности создания и развития предпринимательских сетей в строительстве

4.3 Проблемы развития предпринимательских сетей 166

4.4 Принципы и методы регулирования процессов создания и развития предпринимательских сетей 


\section{ГЛАВА 5}

МЕТОДОЛОГИЧЕСКИЕ ОСНОВЫ ОРГАНИЗАЦИИ

ПРЕДПРИНИМАТЕЛЬСКИХ СЕТЕЙ

5.1 Диагностика предпосылок к сетевой интеграции 184

5.2 Разработка программ формирования предпринимательской сети и оценка ее эффективности

5.3. Региональные сети: бизнес-центры; бизнес -инкубаторы 190

5.4.Инновационные предпринимательские сети: технологические парки; технологические полисы.

ЗАКЛЮЧЕНИЕ

ПРИЛОЖЕНИЯ 